\title{
EFEITOS DE POLÍTICAS PÚBLICAS SOBRE A PRODUÇÃO DE MANDIOCA NO BRASIL
}

\author{
CARLOS ESTEVÃO LEITE CARDOSO \\ Engenheiro Agrônomo
}

Orientador: Prof. Dr. EVARISTO MARZABAL NEVES

Dissertação apresentada à Escola Superior de Agricultura "Luiz de Queiroz", da Universidade de São Paulo, para obtenção do título de Mestre em Agronomia, Área de Concentração: Economia Agrária. 


\section{Cardoso, Carlos Estevão Leite}

Efeitos de políticas públicas sobre a produção de mandioca no Brasil / Carlos Estevão Leite Cardoso. - Piracicaba, 1995.

$180 \mathrm{p}$.

Dissertação (mestrado) - - Escola Superior de Agricultura Luiz de Queiroz, 1996.

Bibliografia.

1. Crédito rural 2. Mandioca - Produção - Politica I. Título 


\title{
EFEITOS DE POLÍTICAS PÚBLICAS SOBRE A PRODUÇÃO DE MANDIOCA NO BRASIL
}

\author{
CARLOS ESTEVÃO LEITE CARDOSO
}

Aprovada em: 05.02.1996

Comissão julgadora:

Prof. Dr. Evaristo Marzabal Neves

ESALQ/USP

Prof. Dr. Ricardo Shirota

ESALQ/USP

Prof. Dr. Gabriel Luiz Seraphico Peixoto da Silva

IEA/SP

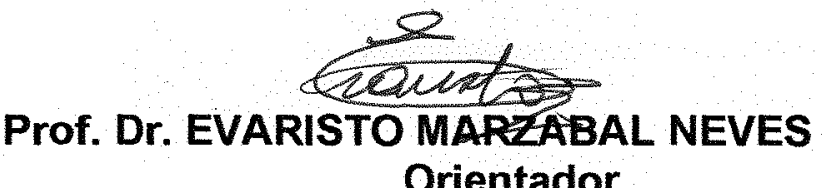

Orientador 
Aos meus padrinhos

Antônio Leite ("in memoriam") e Ana Helena MINHA GRATIDÃO

Aos meus pais e irmãos

RECONHECIMENTO

À minha esposa Maria José e aos nossos filhos Leonardo e Braulio

DEDICO 


\section{AGRADECIMENTOS}

A Deus por tudo.

Ao Prof. Evaristo Marzabal Neves pela orientação, confiança e amizade.

Ao Prof. Paulo F. Cidade de Araújo pelo constante estímulo, amizade e valiosas sugestões em diversas fases deste trabalho. amizade.

Ao Prof. Ricardo Shirota pelas sugestões, paciência, encorajamento e

Ao Prof. Dr. Gabriel L. S. P. da Silva pelas importantes sugestões apresentadas à versão final deste documento.

Ao Pesq. Cient. do Instituto de Zootécnia (IZ/SP) Dr. Abel C. M. Igreja, pela fundamental colaboração, principalmente, na fase de entendimento do modelo shiftshare.

Aos pesquisadores Marney P. Cereda e Olivier Vilpoux do CERAT (Centro de Raízes Tropicais) da UNESP, pelo estímulo e, à Coordenação do Projeto STD3, "Valorização dos produtos, subprodutos e resíduos da industrialização da mandioca na América Latina", pelo apoio financeiro via UE.

Ao Drs. Milton Gomes da Silva (DEPAE/CONAB), e Guilherme Sorria Bastos Filho (FGV) pelo fornecimento de várias séries de dados.

Ao Prof. Dr. Fernando Homem de Melo (FEA/USP) pelas sugestões na fase de definição do tema de estudo.

Aos funcionários do IV Distrito de Meteorologia - Salvador, BA pelo fornecimento dos dados pluviométricos.

A EMBRAPA-CNPMF pela oportunidade de poder realizar o curso de pósgraduação.

Aos Professores do curso de pós-graduação pelos ensinamentos.

Aos colegas de Mestrado, Eduardo, Jaira, Leão, Manoel Vieira, e Ricardo pelo convivio inesquecivel, amizade e companheirismo. Aos também colegas de Mestrado Luis H. Andia e Gabriela pela agradável convivência.

Aos novos amigos Ricardo Cotta, Rodrigo, Clóvis Almeida, Luiz Artur e Jesus Osório pelo apoio.

Aos colegas de trabalho José da Silva Souza, Ranulfo Corrêa Caldas e Maria das Graças C. de Sena pelo incentivo e apoio durante a realização deste trabalho.

Aos funcionários do Departamento pela atenção sempre dispensada.

Às funcionárias da Biblioteca Setorial Angélica e Luciane pela paciente e efetiva colaboração.

Ao CNPq pela concessão da bolsa de estudo. ortográfica.

A Prof. Maria Isabel C. de Almeida pelas valiosas sugestões na parte

A todas as pessoas que contribuíram direta ou indiretamente para a realização deste trabalho. 


\section{SUMÁRIO}

Página

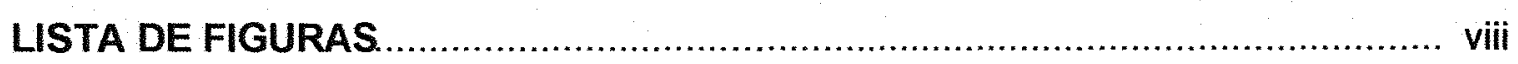

LISTA DE TABELAS

RESUMO

SUMMARY

1. INTRODUÇÃO

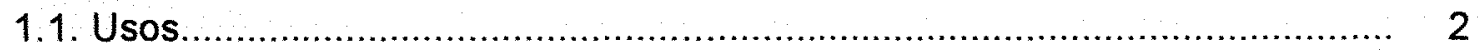

1.2. Evolução da cultura ………......................................................... 3

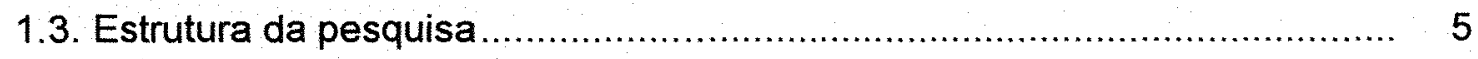

2. IDENTIFICAÇÃO DO PROBLEMA E DEFINIÇÃO DOS OBJJETIVOS ............... 6

2.1. O Problema

2.2. Objetivos

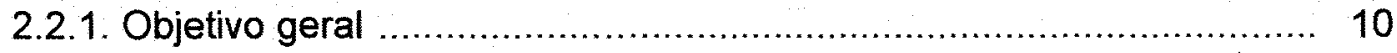

2.2.2. Objetivos especificos ............................................................. 11

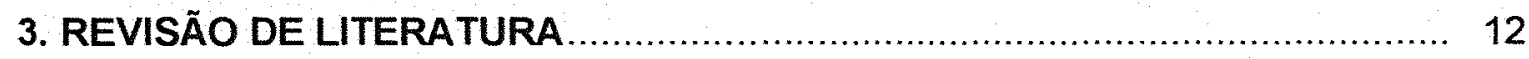

3.1. Alguns indicadores de desempenho ............................................. 12

3.2. As politicas governamentais e desempenho do setor agricola ................ 21

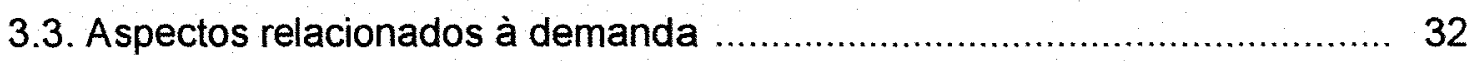

4. METODOLOGIA

4.1. Considerações teóricas relativas a algumas políticas públicas ................. 36

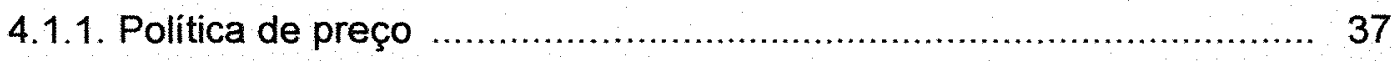

4.1.2. Política de crédito ............................................................. 40

4.1.3 Politica de mudança tecnológica .................................................. 46

4.1.4. Políticas de incentivos diferenciados ........................................... 51 
4.1.5. As politicas públicas e sua relação com a tomada de decisão dos

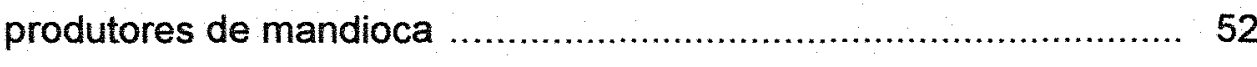

4.2. Fatores associados à produção de mandioca: modelo analítico $\ldots \ldots \ldots \ldots \ldots . \ldots 8$

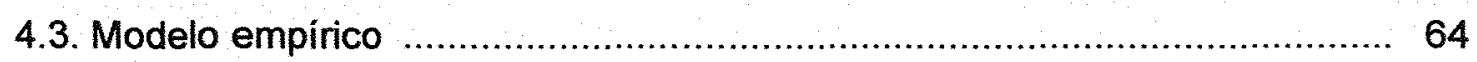

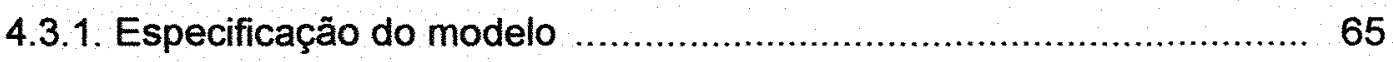

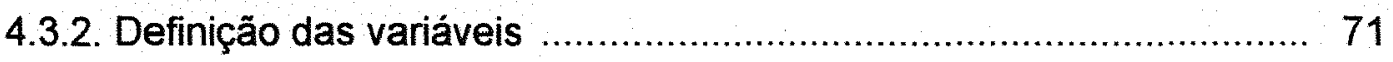

4.4. Outros procedimentos metodológicos utilizados no estudo ..................... 75

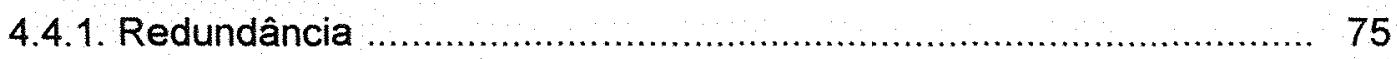

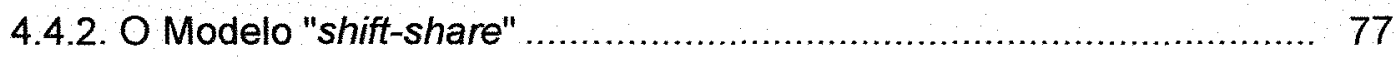

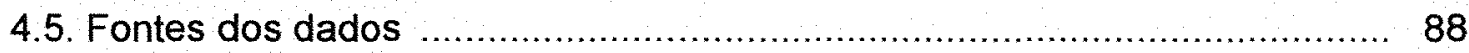

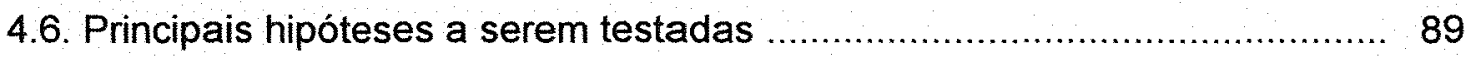

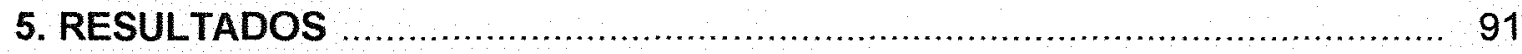

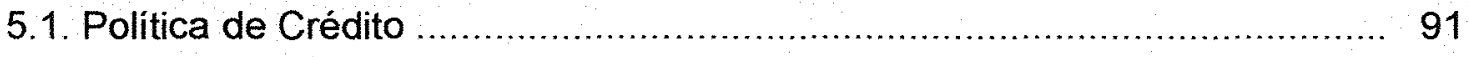

5.1.1. Resultados de outros estudos ...................................... 91

5.1.2. O crédito rural e a cultura da mandioca: análise dos resultados ....... 96

5.2. A política de mudança tecnológica .................................................. 108

5.2.1. Contribuição do rendimento físico para a produção de mandioca ..... 108

5.2.2. Investimentos em pesquisa.............................................. 117

5.3. As politicas de incentivo diferenciado e as transformações estruturais da

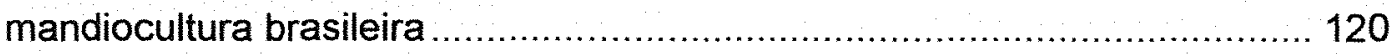

5.4. As politicas públicas e o desempenho da cultura da mandioca: uma visão

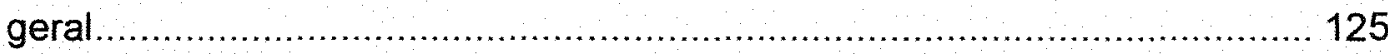

5.4.1. Testando a existência de correlação contemporânea.................... 125

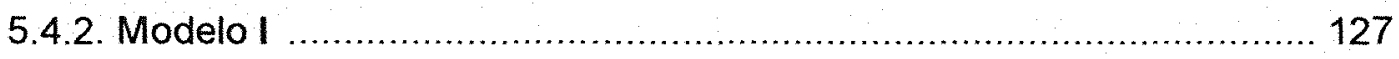

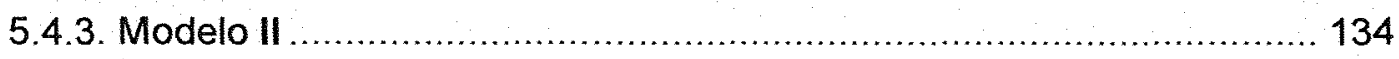

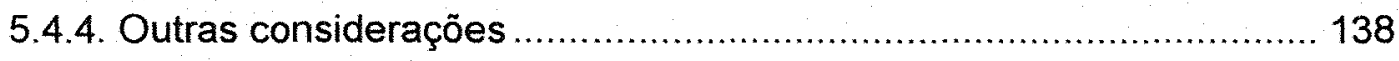

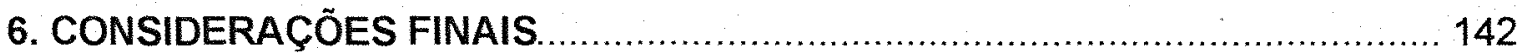


REFERÊNCIAS BIBLIOGRÁFICAS 150 APÊNDICE 161 


\section{LISTA DE FIGURAS}

Figura $\mathrm{N}^{\mathrm{O}}$

Páginas

01 Evolução da produção de mandioca no Brasil, 1931-94

02 Evoluçăo dos preços (U\$/t) recebidos pelos produtores de

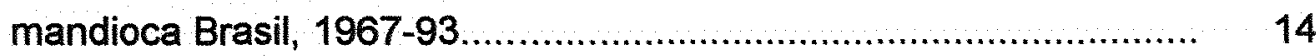

03 Evolução da área e do rendimento de mandioca, no Brasil, 197085.

04 Potencialidades de uso do amido no Brasil.

05 Evolução do rendimento físico por unidade de área de mandioca, no periodo de 1931 a 1994 , Brasil.

06 Rendimento físico médio ( $\mathrm{kg} / \mathrm{ha}$ ) da cultura da mandioca por regiões fisiográficas, no periodo $1965 / 94$

07 Participação relativa dos recursos aplicados pela EMBRAPA para a pesquisa em mandioca, $1976-1994$.

08 Participação da área colhida com mandioca na área total regional:

Brasil, Sudeste, Sul e Centro-Oeste, 70/72 a 90/92 


\section{LISTA DE TABELAS}

Tabela $\mathrm{N}^{\mathrm{o}}$

Páginas

01 Colocação dos produtos agrícolas em ordem decrescente da instabilidade da receita total, Brasil, 1948/76, 1966/76 e 1977/84.

02 Separação da variação da receita total (desprezando interações) nos componentes área cultivada, rendimentos e preços, Brasil, $1977 / 84(\%)$

03 Efeito escala e efeito substituição na cultura da mandioca, Brasil e regiōes, 1980-89.

04 Características básicas dos grupos de produtores de mandioca, Brasil

05 Participação relativa da cultura da mandioca no volume total do crédito rural para custeio, Brasil, 1969, 1973, 1977, 1980, 1985 e 1990.

06 Participação relativa das principais culturas no valor total do crédito rural para custeio, Brasil, 1980, 1985 e 1990.

07 Participação relativa das principais culturas na área colhida e no valor da produção, Brasil, 1980, 1985 e 1990

08 Redundância da distribuição do crédito rural em relação à área colhida e ao valor da produção das 13 (treze) culturas selecionadas, Brasil, 1980, 1985 e 1990

09 Razão de concentração $\left(\mathrm{CR}_{4}\right)$ para as variáveis, crédito rural, área colhida e produção relacionada com a cultura da mandioca, Brasil, 1970, 1975, 1980, 1985 e 1990

10 Redundância da distribuição do crédito rural para os produtores de mandioca de todas Unidades da Federação, em relação à área colhida e à produção da cultura, Brasil, 1970, 1975, 1980, 1985 e 1990

11 Evolução do rendimento físico médio por unidade de área $(\mathrm{Kg} / \mathrm{ha})$ da cultura da mandioca, no periodo, de 1931 a 1994, Brasil. 
12 Área, produção, rendimento físico, indice de rendimento e participação dos estratos de área na produção de mandioca no Brasil, 1970, 1975, 1980 e 1985 ..

13 Taxas anuais de crescimento e fontes de crescimento da cultura da mandioca, por estrato de área total, $1970 / 75$ e 1975/80, Brasil

14 Taxas anuais de crescimento e fontes de crescimento da cultura da mandioca, por estrato de área total, $1985 / 80$ e 1975/85, Brasil.

15 Participação relativa dos recursos aplicados pela EMBRAPA para a pesquisa em mandioca, milho, trigo e soja, 1976 a 1994.

Efeito área total da cultura da mandioca decomposto em efeito escala e efeito substituição, 1970/75, 1975/80, 1980/85 e 1975/85, Brasil.

17 Indice de reestruturação de cultivo da cultura da mandioca, nos Períodos 1970/75, 1975/80, 1980/85 e 1975/85, Brasil.

18 Resultados dos testes para a verificação da existência de Correlação contemporânea, nos modelos I e II.

19 Resultados do ajustamento da equação referente ao Estado do Pará (modelo I).

20 Resultados do ajustamento da equação referente ao Estado do Maranhão (modelo I), após a correção dos problemas de Correlação serial.

21 Resultados do ajustamento da equação referente ao Estado da Bahia (modelo I), após a correção dos problemas de correlação serial.

22 Resultados do teste estatístico usado para comparação dos modelos.

23 Resultados do ajustamento da equação estimada pelo processo Chamado de pooling (modelo II), considerando-se o modelo de covariância, com as devidas correções dos problemas de autocorrelação dos resíduos (Estados de Minas Gerais, São Paulo, Paraná e Rio Grande do Sul). 


\section{LISTA DE TABELAS DO APÉNDICE}

A1 Área colhida, produção, rendimento médio, participação relativa na produção $e$ índice de rendimento de mandioca nas Unidades da Federação e nas regiōes fisiográficas, Brasil, 1994.

A2 Maiores indices de reestruturação de cultivo negativo (IREC-), Brasil.

A3 Maiores índices de reestruturação de cultivo positivo (IREC ${ }^{+}$), Brasil.

A4 Matriz de covariância dos erros das equaçōes componentes do modelo I [sigma $(\sigma)$ ], Pará, Maranhão e Bahia

A5 Matriz de covariância dos erros das equações componentes do modelo II [sigma $(\sigma)$ ], (Minas Gerais, São Paulo, Paraná e Rio Grande do Sul)

A6 Matriz de correlação linear simples, modelo I, Estado do Pará 166

A7 Resultados do ajustamento da equação referente ao Estado do Maranhão (modelo l).

A8 Matriz de correlação linear simples, modelo I, Estado do Maranhão

A9 Resultados do ajustamento da equação referente ao Estado da Bahia (modelo I).

A10 Matriz de correlação linear simples, modelo I, Estado da Bahia.......

A11 Resultados do ajustamento da equação referente aos Estados de Minas Gerais, São Paulo, Paraná e Rio Grande do Sul, estimada pelo processo chamado de pooling - sem as variáveis binárias (modelo II)

A12 Resultados do ajustamento da equação referente aos Estados de Minas Gerais, São Paulo, Paraná e Rio Grande do Sul, estimada pelo processo chamado de pooling (modelo II), considerando-se o modelo de covariância.

A13 Matriz de correlação linear simples, modelo II, pooling (Minas Gerais, São Paulo, Paraná e Rio Grande do Sul). 
A14 Resultados do ajustamento da equação estimada pelo processo chamado de pooling (modelo II), considerando-se o modelo de covariância, com as devidas correções dos problemas de autocorrelação dos resíduos e heterocedasticia (Estados de Minas Gerais, São Paulo, Paraná e Rio Grande do Sul)......................... 174

A15 Dados utilizados no ajustamento do modelo I............................ 175

A16 Dados utilizados no ajustamento do modelo II.............................. 177

A17 Dados básicos utilizados no cálculo da redundância da distribuição do crédito rural entre culturas

A18 Dados básicos usados no cálculo da redundância da distribuição do crédito rural entre Estados 


\title{
EFEITOS DE POLITICAS PÚBLICAS SOBRE A PRODUÇÃO DE MANDIOCA NO BRASIL
}

\author{
Autor: CARLOS ESTEVÃO LEITE CARDOSO \\ Orientador: Prof. Dr. EVARISTO MARZABAL NEVES
}

\section{RESUMO}

Este trabalho teve como objetivo avaliar os efeitos das politicas governamentais sobre a produção de mandioca. Avaliaram-se os efeitos das políticas de preço, crédito rural, mudança tecnológica e incentivos diferenciados.

A politica de crédito rural foi analisada considerando-se os seguintes aspectos: abrangência, volume e posição relativa do crédito rural para mandioca em relação às demais culturas e aos Estados. Adicionalmente, com o objetivo de demonstrar o comportamento da distribuição do crédito rural foi, utilizado o cálculo da redundância, que é uma medida de concentração e/ou desigualdade. $\mathrm{O}$ modelo "shift-share" (também denominado diferencial estrutural) foi utilizado para se analisar os efeitos, tanto da política de mudança tecnológica quanto da política de incentivo diferenciado aos produtos concorrentes da cultura da mandioca. Foram especificados modelos de regressão, de tal forma que foi possivel a avaliação dos efeitos relativos da politica de preço e das demais políticas públicas sobre a produção de mandioca.

Os resultados alcançados oferecem indicativos de que a política de preço, centrada na politica de garantia dos preços mínimos, não foi eficiente para incrementar a produção da cultura da mandioca. Com raras exceções, no periodo estudado os preços mínimos foram fixados muito abaixo dos preços de mercado. Com relação ao crédito rural, observou-se que houve tendência de concentração do 
crédito na década de 80 , comparativamente à de 70 , tanto no aspecto do comportamento agregado das culturas, como no caso especifico da cultura da mandioca em relação aos Estados. Ademais, os valores estimados das elasticidadescrédito da produção sugerem que a política foi de pouca relevância para a mandiocultura nacional.

Constatou-se também que a fonte de crescimento mais importante para a produção da cultura da mandioca, no período de 1931-94, foi a mudança na área, pois o rendimento físico por unidade de área, apresentou-se estável. Isto indica que ainda permanecem inalterados os padrōes de crescimento tradicionais de incremento na produção, ou seja, houve pouca incorporação de tecnologias ao longo do tempo e conseqüentemente um fraco desempenho do indicador de política de mudança tecnológica.

Como resultado da combinação dos estímulos proporcionados pelo mercado e pela política de incentivos diferenciados, observaram-se que na fase de intensificação do processo de substituição de culturas, as atividades que mais incorporaram áreas foram: pastagem plantada, soja, café e arroz. A política de incentivos diferenciados foi também medida pelo indice de preço dos produtos "concorrentes" (IPPC). Estatisticamente o coeficiente da variável IPPC sugere que, tudo mais constante, a produção de mandioca na Região Centro-Sul pode não depender do comportamento dos produtos considerados na construção do índice. 


\title{
EFFECTS OF POLICY ON THE CASSAVA PRODUCTION IN BRAZIL
}

\author{
Author: CARLOS ESTEVÃO LEITE CARDOSO \\ Adviser: Prof. Dr. EVARISTO MARZABAL NEVES
}

\section{SUMMARY}

The objective of this study was evaluate the effects of government policies on the cassava production. Effects of price policy, rural credit, technology changes and differential incentives were evaluated.

The rural credit policy was analyzed according to the following features: range, volume and relative placement of rural credit for cassava comparing to other crops and States. Additionally, to demonstrate the behaviour of rural credit distribution, it was used the redundancy calculation, which is a measure of concentration and/or inequality. The "shift-share" model was applied to analyse the effects of either technological change and differential incentive policy to products which are competitors to cassava crop. It was specified a regression model which can make possible an evaluation of relative price and other public policies on cassava production.

The results indicate that price policy, based in guarantee of price policy, was not efficient to increase the cassava production. In this period, except in rare cases, the prices were placed low below market prices. About rural credit, it was detected a trend in credit concentration in the decade of 80 when compared to the 70 , in both 
aspects of aggregated crop behaviours and specific case of cassava in relation to States. Besides, estimate values of production credit-elasticity suggested that this policy was less relevant to national production.

It was also found that the main source to improve cassava production, in the 1931-94 period, was due to change in area since yield per area remained stable. This indicates that traditional growth patterns in production remain unchanged, meaning that there was little technology assimilation as time goes by and consequently a weak performance as indicator of technological changing policy.

The following activities had incorporate more areas, as results of stimulus combination provide by market and differentiated policies, in the stage of intensification of crop changing process: pasture, soybean, coffee an rice. The differentiated incentive policy was also measure by the index of competitor product price (ICPP). The coefficient of the variable ICPP statistically suggests that, if all other parameters remain constant, the cassava production in the Center-South region may not depend upon the behaviour of products used in the calculation of this index. 


\section{INTRODUÇÃO}

A mandioca é cultivada em todas as regiões do Brasil, assumindo destacada importância na alimentação humana e animal, além de ser utilizada como matériaprima em inúmeros produtos industriais. Entretanto, não consegue manter um padrão estável de produção ao longo do tempo apresentando uma significativa oscilação, principalmente, na sua área cultivada e no preço. Como conseqüência, verifica-se uma variação na renda auferida pelos produtores.

Tradicionalmente, a mandioca tem papel fundamental no Brasil, tanto como fonte de energia (como fonte de proteina ainda é pouco usada) para a alimentação humana e animal, quanto como fonte de emprego e de renda, notadamente, nas áreas pobres da Região Nordeste.

Os dados de ESTUDO NACIONAL DA DESPESA FAMILIAR (1981) indicam que para as familias na faixa de renda de menos de 1(um) salário minimo, o consumo de mandioca e seus derivados representa $9,57 \%$ da despesa anual em alimentação. Ela só perde em importância para o feijão, que aparece com um consumo equivalente a $13,19 \%$ dessa despesa. Esses dados ratificam a importância do produto para as classes de renda mais baixa.

A produção nacional da cultura em 1994 foi de 24,5 milhões de toneladas, com rendimento médio de 13,2 toneladas de raizes por hectare (Tabela A1). Dentre os principais Estados produtores, Pará $(15,26 \%)$, Paraná, $(13,99 \%)$, Bahia $(12,30 \%)$ e Maranhão $(8,97 \%)$ em conjunto são responsáveis por mais de $50 \%$ da produção do pais. Na distribuição da produção pelas diferentes regiões fisiográficas do Pais, a 
Região Nordeste se sobressai com uma participação de $37,7 \%$ da produção, porém, com rendimento médio de apenas $10.157 \mathrm{Kg} / \mathrm{ha}$. As Regiões Norte e Nordeste destacam-se como principais consumidoras, sendo a produção essencialmente utilizada na dieta alimentar, na forma de farinha. Nas Regiões Sudeste e Sul, com rendimento médio respectivo de $16.136 \mathrm{Kg} / \mathrm{ha}$ e $18.656 \mathrm{Kg} / \mathrm{ha}$, é onde se concentra a maior parte da produção orientada para a indústria, principalmente nos Estados de Minas Gerais, São Paulo e Paraná.

\subsection{Usos}

Com relação aos produtos derivados da mandioca, no Brasil, as raizes da cultura são amplamente utilizadas na industrialização de farinha e fécula e para o consumo direto de mesa ("aipim" ou macaxeira).

A mandioca tem grande número de usos correntes e potenciais, que podem ser classificados em função do tipo de raiz, em duas grandes categorias: (i) mandioca de mesa; e (ii) mandioca industrial.

A maioria da mandioca de mesa é comercializada na forma "in natura". O principal problema encontrado para o consumo direto é a perecibilidade das raizes. Isso obriga o seu consumo sem resfriamento no tempo máximo de 24 horas após a colheita Outro problema que afeta esse consumo é a baixa qualidade das raizes comercializadas que nem sempre são adaptadas às características do mercado. Há indícios de um considerável potencial de mercado para a mandioca pré-cozida e congelada, não só no Brasil como no exterior (VILPOUX, 1994).

Segundo esse autor, a mandioca para a indústria tem uma grande variedade de usos, dos quais a farinha e a fécula são os mais importantes. A farinha tem essencialmente uso alimentar $e$, além dos diversos tipos regionais que não modificam as características originais do produto, ela se encontra em duas formas: (i) a farinha 
não temperada, que se destina a alimentação básica e é consumida principalmente pelas classes de renda mais baixa da população; e, (ii) a farinha temperada (farofa), de mercado restrito, mas de valor agregado elevado. Esse tipo de farinha destina-se às classes de renda mais alta da população.

O mercado internacional de mandioca, sem considerar o comércio interno na União Européia, movimenta cerca de 10 milhões de toneladas de produtos derivados ("pellets" e farinha de soja/mandioca), sendo equivalente a mais de U\$ 1.0 bilhão de dólares. Os países da União Européia, Alemanha, Holanda e Bélgica importam a maior parte dos "pellets" de raspas de mandioca produzidos no mundo, especialmente, para utilização em ração animal. A Tailândia é o principal exportador mundial: vende cerca de $80 \%$ de sua produção para a Europa e, juntamente com a Indonésia, atende na sua quase totalidade ao mercado internacional de mandioca (FAO, 1994). O principal fator do domínio de mercado pelos países asiáticos, está nos investimentos realizados pelos empresários europeus naqueles países e nas cotas preferenciais, além dos preços mais baixos do que no Brasil, o qual tem participação reduzida no mercado internacional.

\subsection{Evolução dA Cultura}

A análise da evolução da produção de mandioca no Brasil mostra que essa cultura apresentou uma significativa evolução no período entre a década de 30 e o início dos anos 70 . No início da década de setenta (Figura 01) a cultura da mandioca atingiu sua produção máxima. A partir dessa época muitos fatores têm sido responsáveis pelo desempenho decadente do setor. Entretanto, a cultura não perdeu sua importância como demandadora de mão-de-obra nas regiōes de agricultura tradicional. Por exemplo, para atender pouco mais de novecentos mil hectares 
plantados na Região Nordeste, sem considerar as etapas de processamento, são necessários mais de oitenta milhões de dias-homens por ciclo.

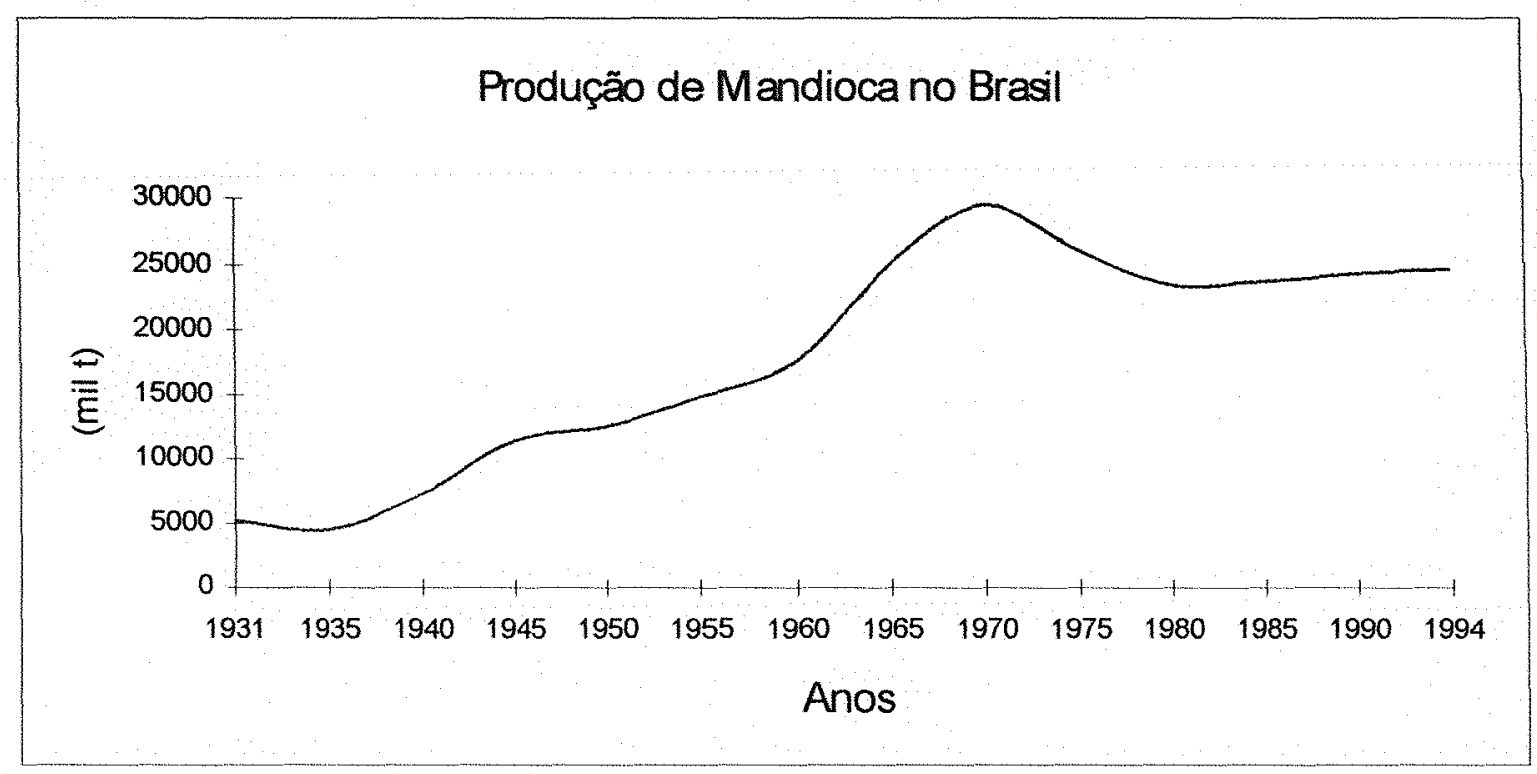

Fonte: Dados básicos - IBGE, 1990.

Figura 01 - Evolução da produção de mandioca no Brasil, 1931-94.

Dentre os fatores considerados importantes na explicação da fraca performance do setor mandioqueiro no Brasil, estão as políticas governamentais (1) orientadas para beneficiar o setor industrial, em primeiro plano, e as culturas de exportação e energéticas, em especial o trigo, em plano secundário.

A análise dos efeitos das politicas públicas no desempenho dos produtos proporciona considerável esclarecimento a respeito do potencial de resposta dos produtores às diferentes formas de intervenção governamental. $E$, dessa maneira, oferece indicativos para que os formuladores de política possam implementar ajustes necessários na condução das referidas políticas.

(1) Neste trabalho as expressões "políticas públicas" e "políticas governamentais" são usadas como sinônimos. 


\subsection{ESTRUTURA DA PESQUISA}

Neste estudo pretende-se avaliar os efeitos das políticas governamentais sobre o desempenho da produção de mandioca, procurando-se identificar as principais variáveis determinantes do padrão de comportamento do setor. Além desta introdução, onde foram apresentados alguns aspectos gerais da cultura, este estudo contém outros cinco capítulos. No segundo Capitulo será efetuada a identificação do problema e a definição dos objetivos. No Capitulo 3 , apresenta-se a revisão de literatura que está subdividida em três seções, englobando os indicadores de desempenho, o comportamento do setor agricola frente às políticas públicas e alguns aspectos relacionados à demanda da cultura.

O Capítulo 4 está dividido em seis seçōes. Ele tem como objetivo apresentar as considerações teóricas referentes às políticas públicas contempladas neste estudo e procura estabelecer as relações entre essas políticas e a tomada de decisão dos produtores de mandioca. Ademais, objetiva apresentar os modelos analítico e empirico e os procedimentos metodológicos utilizados. Finalizando o capítulo, são relacionadas as fontes de informações e levantadas as principais hipóteses a serem testadas.

No Capítulo 5 , são expostos os resultados e a discussão dos mesmos. Nas seções iniciais deste capitulo têm-se um tratamento especifico para as políticas de crédito rural, de mudança tecnológica e de incentivo diferenciado. Em seguida, com base nos modelos econométricos propostos é feita uma abordagem geral dos efeitos das políticas públicas sobre o desempenho da produção da mandioca. Para finalizar o estudo, no Capitulo 6, são apresentadas as principais conclusões. 


\section{IDENTIFICAÇÃO DO PROBLEMA E DEFINIÇÃO DOS OBJETIVOS}

\subsection{O PROBLEMA}

Desde a Segunda Guerra Mundial até meados dos anos 60, o Brasil caminhou para etapas mais avançadas do processo de industrialização. A ênfase na industrialização era tida como uma importante estratégia politica, capaz de tirar o País de seu estado de atraso econômico, social e político. Para consecução do objetivo de alcançar o desenvolvimento econômico com base no crescimento industrial, o governo brasileiro implementou um conjunto de medidas em que a agricultura foi na melhor das hipóteses negligenciada, e na pior das hipóteses severamente discriminada (SCHUH, 1983).

Dentre essas medidas, pelo menos quatro políticas parecem ter tido um maior efeito sobre a agricultura ( $\mathrm{SCHUH}, 1977)$ :

(i) industrialização via substituição de importações. Na verdade, esta política incorporava uma série de instrumentos que foram complementados pelas politicas citadas a seguir;

(ii) tarifas protecionistas muito altas. Esta política foi implementada com objetivo de criar barreiras de proteção à indústria doméstica nascente;

(iii) supervalorização das taxas de câmbio e estabelecimentos de taxas múltiplas. O desejo explícito desta política era abaixar os preços de máquinas, equipamentos e insumos importados indispensáveis à industrialização. As taxas de 
câmbio múltiplas, também eram um reflexo da intenção de favorecer determinados setores da economia; $e$,

(iv) politicas crediticias e fiscais para estimular a indústria. Esta politica, pela clareza dos seus objetivos, dispensa maiores comentários.

Não se pode negar, que um conjunto de condições político-econômicas existentes no Brasil naquela época, favoreceram a implantação do modelo de industrialização proposto. VEIGA (1977) e SERRA (1983) consideram que estes condicionantes podem ser agrupados nos seguintes pontos: "(...) Em primeiro lugar, o comércio restrito durante os anos de guerra e a lenta recuperação posterior dos paises mais envolvidos, possibilitaram um substancial estímulo a ainda incipiente indústria brasileira. (..) Uma segunda condição favorável à industrialização foi a disponibilidade de divisas com as quais puderam ser importados os bens de capital e matérias-primas necessários à modernização e ao abastecimento do parque industrial existente, assim como a sua ampliação. (...) Em terceiro lugar, houve a possibilidade de manter as taxas de inflação interna em niveis relativamente baixos, evitando assim os problemas decorrentes de alocação de recursos e propiciando uma relativa estabilidade nas expectativas de renda e demanda. Isto foi, em parte, conseguido por tabelamentos de preços e proibições de exportação" (VEIGA, 1977). Ademais, "(..) o crescimento da oferta agrícola a uma taxa média superior a $4 \%$ a.a. sem que o setor demandasse um volume significativo de investimentos e recursos financeiros", deve ter sido de vital importancia dentro desse processo (SERRA, 1983). Finalmente, uma quarta condição foi o clima de ordem e estabilidade política que caracterizou o Pais durante o periodo de 1946-50.

A formulação de uma politica de desenvolvimento econômico sem considerar a importância da agricultura parece implicitamente assumir a possibilidade de um fluxo de recursos líquidos que seriam retirados da agricultura. Ou seja, este setor seria suficientemente capaz de gerar excedentes para implementar o processo de 
crescimento via industrialização. Entretanto, a adoção de politicas dessa natureza por longo tempo gera distorções no mercado de fatores e de produtos. $E$, como consequência, reflexos negativos no desenvolvimento do setor agrícola.

As principais consequências especificas dessas políticas para a agricultura foram as que seguem (SCHUH, 1977): (i) fracasso evidente no desenvolvimento do setor de exportação, que era liderado pela agricultura. Esperava-se que com a redução das importações, proporcionada pela industrialização, a balança de pagamentos seria mantida em equilibrio e, assim não haveria necessidade de aumento nas exportações; (ii) fracasso em desenvolver a capacidade de suprir insumos modernos. Argumenta-se que devido ao peso de determinados bens de consumo na pauta de importação naquela época, o processo de substituição de importações priorizou a industrialização desses bens, relegando a segundo plano as indústrias fornecedoras de insumos agricolas; e (iii) perda de competitividade dos produtos agricolas nos mercados internacionais. A moeda sobrevalorizada tornava os preços dos produtos domésticos exportáveis (na maioria agricolas) mais caros do que os praticados no mercado internacional. Além disso, a proibição de exportações de alimentos por causa da politica de "alimento barato", agravava a situação. Como conseqüência, os preços internos não encorajavam investimentos na agricultura. Outras conseqüencias para a agricultura poderiam ser citadas, como por exemplo: transferências de renda e atraso tecnológico.

Em última análise, com ênfase no processo de industrialização, a agricultura não contribuiu para o desenvolvimento econômico com todo o potencial que poderia ter feito. Houve problemas de abastecimento interno e as exportações não atingiram os niveis esperados. No inicio dos anos 60 , a economia brasileira passou por um processo de desaceleração do crescimento experimentado com a politica de substituição de importações. A inflação alcançou níveis alarmantes para aquela 
época e, o déficit na balança de pagamentos atingiu grandes proporções. Neste cenário de dificuldades, a agricultura deixa de ser problema para ser solução.

Neste sentido, os formuladores da politica econômica compreenderam que a agricultura tinha um importante papel no processo de desenvolvimento. $E$, explicitamente, observa-se a orientação das políticas públicas para "compensar" o setor primário da discriminação imposta no passado. Na verdade, esta reorientação deslocava o interesse da política agregada, para, ao mesmo tempo, restabelecer o equilíbrio interno (ou seja, controlar a inflação), reduzir o déficit comercial e ampliar o mercado de produtos manufaturados, via demanda de bens de capital (máquinas e equipamentos) e insumos modernos por parte da agricultura.

PEREIRA (1992) argumenta que a compensação, via subsídios, era mais para viabilizar a adoção do "pacote tecnológico" recomendado, pois, a racionalidade dos produtores levaria ao uso dos fatores de produção abundantes, no caso, terra e mãode-obra, já que a estrutura fundiária manteve-se inalterada. De qualquer forma, o que importa no momento é que políticas públicas de incentivo ao setor foram implementadas. É neste período que se implanta a estrutura de garantia de preços agricolas, se institucionaliza o crédito rural, ampliam-se os programas de geração de tecnologia, inicia-se a política de subsidios ao trigo, consolida-se o serviço de extensão, etc. Todavia, os produtores dos diferentes produtos responderam a esses incentivos de forma diferenciada. Portanto, a questão relevante a ser considerada é: quais os efeitos dessas políticas públicas de incentivo ao setor primário no desempenho da cultura da mandioca?

Em termos mais específicos, são colocadas às seguintes questões básicas:

(1) "Sabemos que, quanto mais próximo da condiçōes de equilibrio for o preço mínimo fixado por antecipação, maior o impacto da política sobre a oferta e sobre a mudança tecnológica rural, a longo prazo" (CONTADOR, 1979). Sendo verdadeira esta premissa, qual foi o comportamento do preço minimo de garantia em relação ao 
preço de mercado da cultura da mandioca, e seu respectivo impacto no desempenho do setor? Espera-se que, no caso da mandioca, dado ao seu desempenho nos últimos anos - produção total decrescente e nível baixo de incorporação de tecnologia - os preços mínimos de garantia tenham sido fixados muito abaixo da condição de equilibrio de mercado entre a oferta e a demanda.

(2) A maneira como foi implementado o crédito agrícola no Brasil e as caracteristicas da cultura da mandioca parecem indicar uma posição marginal da cultura frente a essa política. Entretanto, qual foi a participação da mandioca na politica de crédito e, efetivamente, o impacto desta politica no desempenho da mandiocultura brasileira?

(3) Qual a contribuição da política de desenvolvimento tecnológico no desempenho da cultura da mandioca e o grau de atenção dispensado pelas instituições governamentais às demandas tecnológicas do setor?

(4) A correlação negativa entre a política de subsidio ao trigo e o desempenho da cultura da mandioca, tem sido assumida como verdadeira, pelo menos enquanto permaneceram os incentivos à produção do trigo. Por outro lado, até o momento, parece que as mudanças ocorridas na política do trigo não causaram o impacto esperado. Dadas essas considerações, quais os reflexos da política do trigo no desempenho da cultura da mandioca?

\subsection{OBJETIVOS}

\subsubsection{Objetivo Geral:}

Analisar impactos diretos e indiretos, das politicas governamentais no desempenho da produção de mandioca, procurando identificar as principais variáveis determinantes do padrão de comportamento do setor. 


\subsubsection{Objetivos Especificos:}

(1) Avaliar o impacto da politica de garantia de preços no desempenho da cultura da mandioca.

(2) Analisar a distribuição e a posição relativa do crédito para a mandioca frente a outros produtos. Complementarmente, pretende-se examinar a relação entre a política de crédito rural e a produção de mandioca.

(3) Identificar o grau de atenção dispensado pelo poder público e avaliar a contribuição da política de desenvolvimento tecnológico no desempenho da cultura da mandioca.

(4) Quantificar o impacto das políticas de incentivo diferenciado, dirigidas aos produtos concorrentes da mandioca, na produção e no consumo. 


\section{REVISÃO DE LITERATURA}

\subsection{ALGUNS INDICADORES DE DESEMPENHO}

Inicialmente são apresentados alguns indicadores de desempenho com base em diversos autores. $\dot{E}$, também, apresentado o padrão de comportamento da cultura da mandioca na década de oitenta, com relação aos efeitos "escala" e "substituição".

O Brasil saiu de uma produção em torno de 5 milhões de toneladas na década de 30, para uma produção de mais de 23 milhões de toneladas no inicio da presente década. Nesse período, a taxa de crescimento da produção foi de $2,73 \%$ a.a. No inicio dos anos setenta (1971), a produção nacional de mandioca ultrapassou a marca dos 30 milhões de toneladas; a partir daí, iniciou-se a processo de redução até 1984 (Figura 01). Há uma reversão e leve crescimento até 1986 , quando a produção chegou a 25,6 milhões de toneladas. Durante os demais anos, observou-se uma certa estabilização da produção, que em média alcançou 23 milhões de toneladas.

HOMEM DE MELO (1985) analisando o período da chamada "prioridade" agricola brasileira, no governo Figueiredo (1977/84) observou que a cultura da mandioca, a exemplo da batata, teve um expressivo declínio da produção por habitante. No periodo considerado a taxa anual de declínio da produção de mandioca por habitante foi de $5,29 \%$. O autor ressalva que este produto "parece representar o caso mais grave na produção brasileira de alimentos pois, durante $1967 / 76$, portanto 
nos dez anos imediatamente anteriores ao periodo analisado(1), a sua produção por habitante já apresentava uma taxa anual de declínio de $4,3 \% "$.

Com relação às taxas médias anuais de crescimento da área colhida e do rendimento médio por unidade de área da mandioca, os valores alcançados foram, respectivamente, no periodo de $1977 / 84$, de $-1,94 \%$ e $-1,01 \%$. No mesmo período, os grupos das culturas de exportação( 2$)$ e a cana-de-açúcar obtiveram respectivamente taxas de crescimento de $0 \%$ e $7,43 \%$ a.a. para a área e $4,05 \%$ e $2,76 \%$ a.a. para o rendimento por unidade de área. Já o grupo das culturas alimentares, apresentou estagnação tanto em relação a área quanto ao rendimento por hectare, mostrando um desequilibrio tecnológico no sentido das culturas de melhor retorno (HOMEM DE MELO, 1985).

De acordo com este autor, o rendimento médio por unidade de área da cultura da mandioca, no periodo de $1977 / 84$, foi menor do que aqueles do início dos anos 60. Isso se explica pela não incorporação de tecnologia e pelas mudanças estruturais experimentadas pela cultura. "A implicação negativa de não incorporação (e mesmo geração) de novas tecnologias na produção dessa cultura seria a maior necessidade de competição por áreas com as culturas de exportação e cana-de-açúcar. Ou, em outras palavras, o aumento da quantidade produzida desse alimento dependeria da elevação, por algum mecanismo, de seu preço relativo, o que seria prejudicial aos consumidores, particularmente aos de menores rendas".

Com relação à evolução dos preços, no período de $1977 / 84$, a cultura da mandioca comportou-se de modo geral na direção em que não havia estímulo para aumento da quantidade produzida (Figura 02). Primeiro, verificou-se que a cultura

(1) O período da chamada "prioridade agrícola" inicia-se a partir de 1979 , mas como o autor considera que o referido ano, assim como o anterior (1988), não constitui uma base adequada para comparações em função das frustrações de safras (problemas climáticos), optou-se pelo ano de 1977 como base.

(2) Grupo das culturas de exportação: algodão, amendoim, cacau, café, fumo, laranja e soja; Grupo das culturas alimentares: arroz, feijão, milho, mandioca e batata. 
apresentou uma elevada instabilidade dos preços reais recebidos pelos produtores. Segundo, enquanto a maioria dos produtos alimentares refletiam uma tendência de aumento durante $1977 / 80$, a mandioca foi a grande exceção. Terceiro, mesmo em 1983 quando ocorreu uma forte recuperação dos preços reais dos produtos alimentares, novamente a mandioca fugiu à regra. Convém salientar que, apesar do forte declinio dos preços recebidos pelos produtores de culturas alimentaresdomésticas, no periodo $1977 / 84$, a mandioca apresentou uma situação ampliada, em termos da evolução da quantidade produzida e dos preços recebidos em 1982, a sua produção por habitante foi $17 \%$ inferior a de 1977 , enquanto o preço médio recebido foi $66,4 \%$ menor que o de 1977 (HOMEM DE MELO, 1985). Ou seja, houve queda de produção acompanhada de grande redução nos preços (produto com características inelásticas).

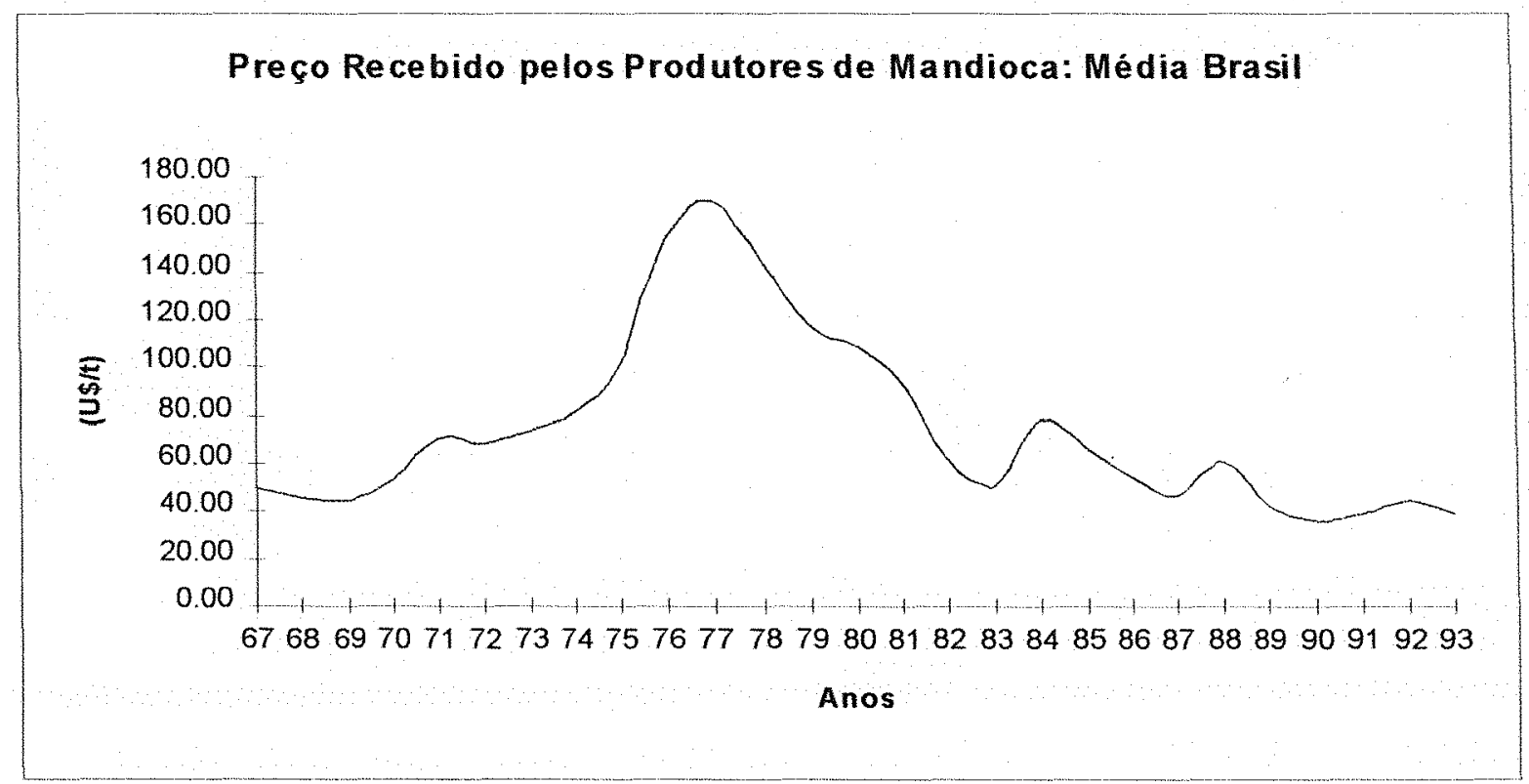

Fonte: Dados básicos FGV (Banco de Dados).

Valores deflacionados pelo IGP-DI/FGV (dez. 92=100), dólar médio de dez./92.

Figura 02 - Evolução dos preços $(U \$ / t)$ recebidos pelos produtores de mandioca, Brasil, 1967-93. 
Um outro indicador importante de desempenho é o indice de instabilidade da receita total recebida pelos produtores, que depende da instabilidade dos preços reais recebidos e da quantidade produzida. HOMEM DE MELO (1986) analisando a instabilidade da receita dos agricultores em algumas culturas, verificou que no periodo de $1977 / 84$, dentre as culturas analisadas $(3)$ a mandioca apresentou o menor valor para o coeficiente de variação da quantidade produzida. Ainda que com coeficiente de correlação positivo entre preços e quantidade demandada - mostrando uma incoerência em termos dos movimentos de preços e quantidade - e mesmo tendo uma instabilidade de preços semelhantes a algumas culturas de exportação, ela apresentou uma magnitude bastante baixa para a instabilidade da receita total (Tabela 1).

Apesar dos indicadores com comportamento desfavoráveis já apresentados, a análise da Tabela 1 mostra que a instabilidade da receita na cultura da mandioca vem apresentando uma tendência declinante ao longo do tempo.

A Tabela 2 apresenta a decomposição da instabilidade da receita em seus três componentes básicos, a saber: variações de área, de rendimentos por área e de preços recebidos pelos agricultores, conforme HOMEM DE MELO (1986). A análise dessa tabela revela que para as culturas domésticas, a instabilidade dos preços é uma fonte mais importante para explicar a instabilidade da receita que a instabilidade das quantidades produzidas. Com relação à instabilidade dos rendimentos, a cultura da mandioca foi a que apresentou o menor valor. Essas constatações indicam que uma eventual ação pública para estabilizar a receita total dessa cultura deveria ser concentrada na estabilização dos preços.

(3) As demais culturas: arroz, feijão, milho, batata, algodão, amendoim, cacau, café, fumo, laranja, soja, cana-de-açúcar e trigo. 
Tabela 1 - Colocação dos produtos agricolas em ordem decrescente da instabilidade da receita total, Brasil, 1948/76, 1966/76 e 1977/84.

\begin{tabular}{cccccc}
\hline \multicolumn{2}{c}{$1948 / 76$} & \multicolumn{2}{c}{$1966 / 76$} & \multicolumn{2}{c}{$1977 / 84$} \\
\hline Cultura & $\begin{array}{c}\text { Coeficiente } \\
\text { de Variação }\end{array}$ & Cultura & $\begin{array}{c}\text { Coeficiente } \\
\text { de Variação }\end{array}$ & Cultura & $\begin{array}{c}\text { Coeficiente } \\
\text { de Variação }\end{array}$ \\
\hline Mandioca & $\mathbf{0 , 5 0}$ & Café & 0,36 & Feijão & 0,27 \\
Feijão & 0,35 & Mandioca & 0,33 & Batata & 0,26 \\
Cebola & 0,32 & Trigo & 0,27 & Algodão & 0,16 \\
Amendoim & 0,31 & Batata & 0,25 & Arroz & 0,16 \\
Batata & 0,30 & Feijão & 0,22 & Milho & 0,15 \\
Café & 0,26 & Amendoim & 0,18 & Laranja & 0,11 \\
Cana & 0,24 & Arroz & 0,17 & Cacau & 0,11 \\
Arroz & 0,23 & Algodão & 0,14 & Trigo & 0,09 \\
Milho & 0,20 & Cana & 0,12 & Café & 0,09 \\
Algodão & 0,20 & Milho & 0,11 & Mandioca & 0,07 \\
& & & & Fumo & 0,07 \\
& & & & Amendoim & 0,07 \\
& & & & Cana & 0,02 \\
\hline
\end{tabular}

Fonte: HOMEM DE MELO (1988) tabela 6, p.132.

É importante destacar a magnitude da variação nos preços da mandioca na determinação da instabilidade da renda total da cultura, sendo inferior apenas à batata com valores de $96,4 \%$ e $97,3 \%$ respectivamente (Tabela 2).

PORTO (1986) analisando os reflexos da política agricola na cultura da mandioca no Brasil até 1984, observa que a partir de 1972 houve uma tendência de estabilização da área cultivada com mandioca no pais e, concomitantemente, uma redução drástica na quantidade produzida de raizes (Figura 03). Desde que a área se manteve relativamente constante, uma redução da produção de raizes teria que ser provocada por uma queda nos níveis de produtividade da cultura por unidade de 
área. Realmente, os rendimentos médios de raizes, que alcançaram um patamar próximo a 15 tha em 1972 cairam abruptamente para 12,2 tha em 1976 e para 10,6 tha em 1983. Segundo HOMEM DE MELO (1985), a taxa média anual de crescimento dos rendimentos da cultura por unidade de área no período de $1970 / 79$ foi de $-2,50 \%$.

Tabela 2 - Separação da variação da receita total (desprezando interações) nos componentes área cultivada, rendimentos e preços, Brasil, $1977 / 84$ (\%).

\begin{tabular}{cccc}
\hline Culturas & Área & Rendimento & Preço \\
\hline Domésticas & & & \\
Arroz & 21,3 & 13,3 & 65,4 \\
Feijão & 16,4 & 8,6 & 75,0 \\
Milho & 7,5 & 43,7 & 48,8 \\
Mandioca & 1,9 & 1,7 & 96,4 \\
Batata & 0,8 & 1,9 & 97,3 \\
Exportáveis & & & \\
Algodão & 12,6 & 33,8 & 53,6 \\
Amendoim & 47,5 & 9,6 & 42,8 \\
Cacau & 0,2 & 5,9 & 93,9 \\
Café & 15,7 & 41,4 & 42,9 \\
Fumo & 3,6 & 8,5 & 87,9 \\
Laranja & 7,2 & 3,4 & 89,4 \\
Soja & 13,4 & 41,4 & 45,2 \\
Administradas & & & 45,9 \\
Cana-de-açúcar & 29,6 & 24,5 & 25,7 \\
Trigo & 42,7 & 31,6 & \\
\hline
\end{tabular}

Fonte: HOMEM DE MELO (1986) tabela 5, p.51.

A estabilização da área colhida com mandioca a partir da década de setenta é também constatada por MESQUITA (1994) através do índice de evolução da área 
colhida no periodo de $1970 / 90$, tomando como base o ano de 1980 (índice médio igual a 100,1$)$. O autor revela que a mandioca sofreu uma pequena redução de área a partir de 1984, mantendo uma certa estabilidade nos anos subseqüentes, com exceção de 1986. Ressalte-se que a área colhida em 1980 é a mesma de dez anos atrás.

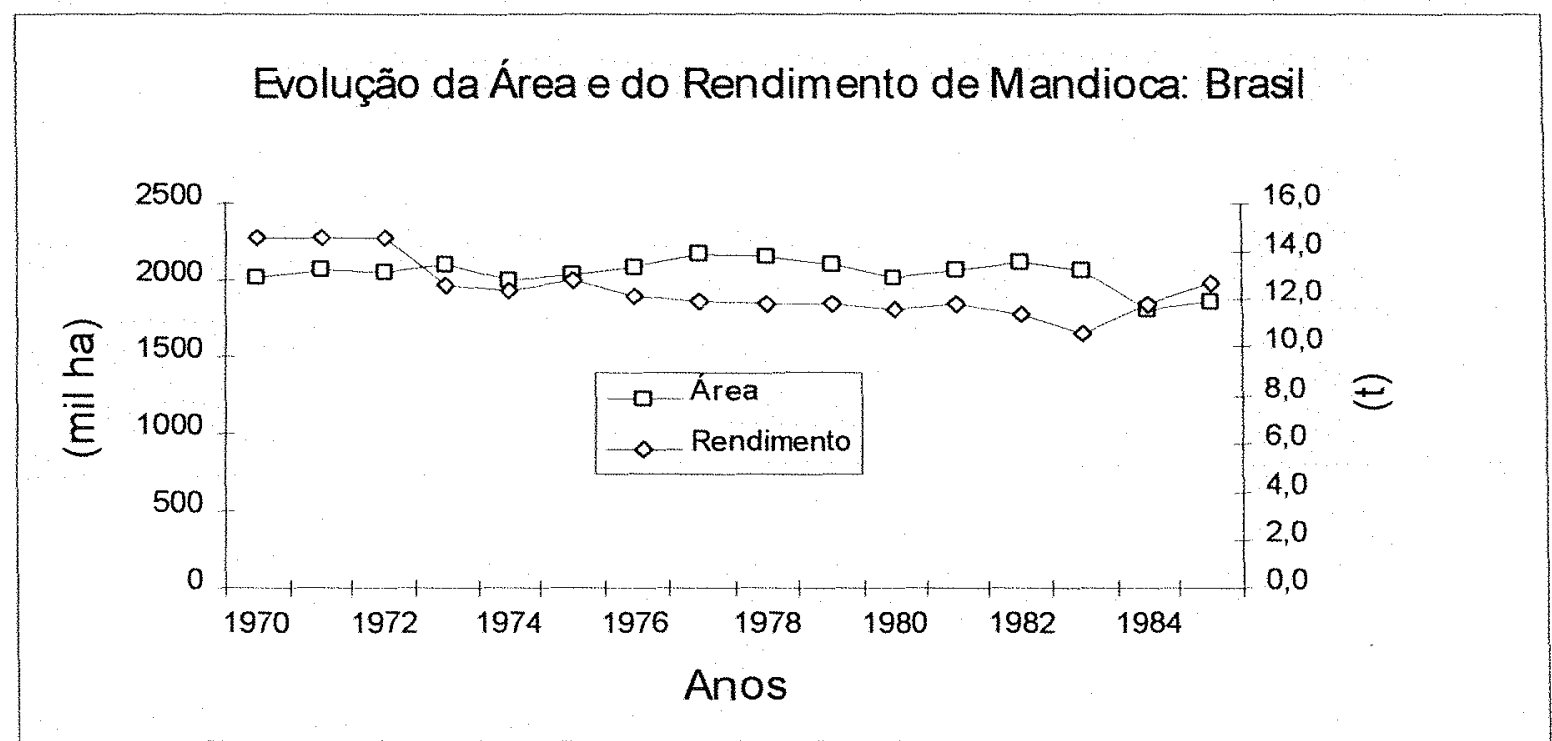

Fonte: Dados básicos - IBGE, 1990.

Figura 03 - Evolução da área e do rendimento da cultura da mandioca, no Brasil, $1970-85$

No entanto na década de oitenta o setor agricola apresentou um crescimento favorável, enquanto a economia como um todo cresceu pouco. Mesmo nos anos de recessão $(81-83)$ o setor agrícola teve um desempenho superior aos demais: o seu produto real caiu menos do que nos demais setores. Embora a agricultura tenha apresentado crescimento favorável, um dos pontos marcantes nessa década foi a persistente queda dos preços verificada para as lavouras e pecuária (GASQUES \& VILLA VERDE, 1990). 
Além do comportamento declinante dos preços, observou-se também uma mudança na composição do produto agrícola, tanto pelo critério de área colhida como de valor da produção. MESQUITA (1994) constatou que no final da década de oitenta houve um aumento da participação dos produtos exportáveis na composição do produto agricola. GASQUES \& VILLA VERDE (1990) verificaram que os produtos alimentares arroz, feijão e mandioca tiveram queda de participação no produto global, refletindo especialmente uma redução da demanda por esses bens, pois seus preços foram decrescentes no periodo.

Segundo GASQUES \& VILLA VERDE (1990) o crescimento da agricultura nos anos oitenta deu-se mais em função da substituição do que pela incorporação de novas áreas. $\mathrm{O}$ algodão arbóreo e os produtos alimentares foram as lavouras sobre as quais incidiu a quase totalidade do efeito substituição: conjuntamente cederam 3,4 milhões de hectares dos 3,9 milhões substituidos. As pastagens não foram consideradas nesse estudo.

Este estudo indicou que no Norte, mesmo sendo região de fronteira, nota-se a ocorrência da substituição de áreas de arroz e mandioca por milho e café. Em todo o país, o Sudeste foi onde os produtos alimentares perderam mais áreas. A cana-deaçúcar juntamente com o café, foram os principais responsáveis por esse processo de substituição. A laranja também tem se expandido em áreas de lavouras alimentares mas numa intensidade bem menor do que a cana-de-açúcar.

Considerando-se o período de $80 / 82$ a $87 / 89$ a cultura da mandioca teve $19,7 \%$ de sua área substituída por outras culturas ou deixada em descanso. Em termos absolutos a Região Nordeste foi a que apresentou a maior área substituída. Já em termos relativos, a Região Sudeste apresenta-se em primeiro lugar. Ou seja, comparando-se com a área do periodo $80 / 82$, a redução da área ocasionada pelo 
efeito substituição de culturas no Sudeste, foi equivalente a aproximadamente $1 / 3$ daquela área (Tabela 3).

Tabela 3 - Efeito escala e efeito substituição na cultura da mandioca, Brasil e Regiões 1980-89.

\begin{tabular}{lcccc}
\hline \multirow{2}{*}{ Brasil e } & \multicolumn{2}{c}{ Médias Trienais de Área } & Efeito & $\begin{array}{c}\text { Efeito } \\
\text { Regiões }\end{array}$ \\
\cline { 2 - 5 } Brasil & $\mathbf{1 9 8 0 / 8 2}$ & $\mathbf{1 9 8 7 / 8 9}$ & Escala & Substituição \\
\hline Nordeste & $\mathbf{2 . 0 6 8 . 3 7 9 , 7}$ & $\mathbf{1 . 8 5 5 . 7 1 8 , 3}$ & $\mathbf{1 9 5 . 0 3 1 , 7}$ & $\mathbf{- 4 0 7 . 6 9 3 , 0}$ \\
Sul & $1.316 .537,7$ & $1.057 .094,0$ & $-8.812,9$ & $-250.630,8$ \\
Norte & $270.951,0$ & $287.491,0$ & $-1.210,3$ & $17.750,3$ \\
Sudeste & $233.067,0$ & $289.653,3$ & $131.808,9$ & $-75.222,6$ \\
Centro-Oeste & $187.572,3$ & $147.119,3$ & $23.259,3$ & $-63.712,3$ \\
\hline
\end{tabular}

Fonte: GASQUES \& VILLA VERDE (1990) quadro 2, p.187-189.

Segundo MESQUITA (1994), verificou-se que com relação ao comportamento da oferta, a exemplo do amendoim, a mandioca apresentou variações importantes no periodo (1970/90), porém em sentido negativo; a quantidade colhida de mandioca sofreu uma redução de $22,5 \%$, com base na comparação entre as médias dos três valores iniciais e dos três valores finais da série analisada.

Um fato a ser destacado é que algumas vezes a mandioca apresentou um comportamento anticiclico dos demais produtos da agricultura. Por exemplo, de acordo com MESQUITA (1994), nos intervalos entre $1970 / 71$ e $1972 / 73$ o setor agricola obteve taxas anuais de crescimento bastante significativas, e nesse mesmo periodo, a cultura experimentou queda drástica de rendimento por unidade de área, conforme relatado por PORTO (1986). 


\subsection{As Políticas Governamentais e o Desempenho do Setor Agrícola}

A seguir são apresentados os resultados de alguns estudos orientados para a análise de diversas politicas governamentais, procurando-se evidenciar a importância destas para o desempenho do setor agricola brasileiro como um todo e, quando possivel, relacionando-as com a cultura da mandioca.

VEIGA (1992) considera que talvez seja possivel falar de uma espécie de padrão de intervenção estatal voltada à modernização da agricultura capitalista. As duas linhas básicas dessas politicas seriam as seguintes:

- investimentos públicos em pesquisa, extensão, infra-estrutura e crédito estimulam um crescimento da oferta em ritmo superior ao crescimento da demanda;

- a política comercial administra uma estável queda dos preços alimentares, compativel com a manutenção de uma aceitável remuneração corrente do trabalho do agricultor e compativel, também, com a regulação do ritmo do êxodo rural exigido, tanto pelo mercado de trabalho urbano, quanto pela necessidade de aumentar paulatinamente 0 tamanho das unidades produtivas.

Considerando-se este padrão de intervenção estatal, é que no presente trabalho serão analisados os efeitos das políticas de preços, de crédito rural, de mudança tecnológica e de incentivo diferenciado $(4)$ aos produtos concorrentes da mandioca no desempenho da mesma.

No tocante a política de preço mínimo, a dimensão de análise a ser adotada refere-se aos aspectos da política de preços agricolas relacionados diretamente com

$\left({ }^{4}\right)$ Neste tabalho o que está sendo considerado como política de incentivo diferenciado é o conjunto de políticas que integram os programas, orientadas para produtos especificos tais como, cana-de-açúcar, trigo, soja etc. 
as politicas macroecônomicas, ou seja, a política de preços mínimos $(5)$ e seus instrumentos de ação.

KRISHNA (1977) revela que é interessante observar que, em todos os países onde foram lançados programas de desenvolvimento baseados em uma politica negativa de preços, a produção agrícola deixou de crescer segundo a taxa desejada, e os planejadores foram compelidos, de bom ou mau grado, a adotar uma politica positiva.

"É fato inconteste de que os produtores agricolas procuram expandir a produção sempre que prevêem aumentos nos preços reais recebidos. Este raciocínio está fortemente documentado pelas evidências empiricas. Mais ainda, existe um relativo consenso de que tal comportamento é generalizado mesmo entre os agricultores de baixa renda. A curva de oferta positivamente inclinada em relação à expectativa de preço é uma evidência que não pode ser ignorada pela política agricola" (CONTADOR, 1979). Ou seja, parece que os produtores não estão dispostos a manterem taxas de crescimento agricola a um nível mínimo desejado pelos planejadores, quando os termos de troca lhes são desfavoráveis, mesmo considerando-se os reduzidos valores das elasticidades-preço da oferta dos insumos básicos primários (mão-de-obra e terra), o que pode obrigar os produtores em determinadas circunstâncias a continuarem o processo de produção visando pelo menos a remuneração, ainda que possivel, dos custos variáveis.

CONTADOR (1979) analisando os beneficios e custos sociais da politica de garantia de preços agrícola no Brasil, calculou o impacto dessa politica nos preços

(5) Segundo MESQUITA (1994), do ponto de vista das relações entre as políticas econômicas e o desempenho do setor agrícola, a análise mais importante é a que se refere aos preços que são exógenos, como a taxa de câmbio e os preços mínimos, tendo em vista que os demais preços (preços dos fatores de produção e os preços recebidos pelos agricultores) são formados no mercado e afetados pelas variações induzidas nos dois primeiros. Partindo deste raciocínio a taxa de câmbio poderia ser também considerada. Entretanto, pelas características da mandioca (produto doméstico), as influências da taxa de câmbio no seu desempenho serão consideradas de forma indireta, via incentivo diferenciado aos produtos concorrentes. 
esperados pelos produtores que seria equivalente ao efeito da política de preços nas decisões de plantio. As simulações efetuadas pelo autor indicaram que, no caso da cultura da mandioca, a politica de preços estaria sendo a mais adequada socialmente - dentro das condições impostas pelo modelo utilizado - se conseguisse elevar em $68 \%$ as expectativas dos preços esperados pelos produtores. Ou seja, a política de garantia de preços para a cultura da mandioca poderia ser bem mais agressiva, em comparação com outras culturas nas quais os indicadores de impacto estavam em níveis mais baixos (soja: $10 \%$; milho: $22 \%$; arroz: $26 \%$; algodão: $28 \%$; e feijão e amendoim: $34 \%$ ). Considerando-se esse resultados, em termos de benefício liquido para a sociedade, seria preferível dar maior estímulo à cultura da mandioca.

Para evidenciar a importância da política de preços mínimos como elemento redutor de risco na comercialização e indutor da tomada de decisão com relação a área a ser plantada e ao nivel de manejo adotado no processo de produção, recorrese à descrição do comportamento do setor agricola brasileiro na década de oitenta efetuado em GASQUES \& VILLA VERDE (1990).

A referida década é considerada uma década perdida para a economia brasileira. Nesse periodo, os preços dos principais produtos agricolas, tanto os domésticos como os internacionais, foram decrescentes, e mesmo assim, o setor apresentou um desempenho satisfatório. Quais as explicações para um comportamento de crescimento numa conjuntura desfavorável de preços?

Entre outros, podem ser citados os diversos fatores relacionados com o tipo de organização da agricultura cujos processos de produção são diferenciados, com ausências de uso alternativo da terra e a natureza do mercado de trabalho rural onde predomina a mão-de-obra familiar. Além disso, outros fatores explicativos são: (i) crescimento da produtividade da agricultura; e, (ii) a redução dos custos de produção ocasionado pela forte tendência de queda de preços dos insumos agrícolas no período. 
Acrescente-se ainda que na década de oitenta, dentre as políticas governamentais, a de garantia de preços mínimos incorporou alteraçóes que a tornaram um dos principais instrumentos de política agrícola, contribuindo significativamente para explicar o desempenho do setor agricola brasileiro.

Uma política de preços de garantia, mesmo que estabeleça preços abaixo do equilibrio, pode influenciar os preços pagos aos produtores. MESQUITA (1994), utilizando o ano de 1980 como base, calculou pelo método de Fisher os índices agregados de preços mínimos para seis produtos $(6)$, no periodo de 1970 a 1990 . autor verificou que os preços mínimos apresentaram uma evolução satisfatória durante o periodo $70 / 89$. Ele atribui como uma possivel consequência dessa política, o fato dos preços recebidos pelos agricultores crescerem continuamente até 1977 , iniciando a partir dai uma trajetória decrescente que prevaleceria até 1982.

Mesquita avaliando a eficácia da Politica de Garantia de Preços Mínimos como estratégia para reduzir flutuações na produção agrícola dos seis produtos considerados anteriormente, verificou que o coeficiente de variação da produção anual dessas lavouras foi muito pequeno $(0,065)$ para todo o período estudado. Isso demonstra o efeito positivo da política de preços mínimos como instrumento de estabilização da produção. Por outro lado, o mesmo autor encontrou que no periodo em estudo a mandioca não apresentou a relação esperada, isto é, uma associação positiva entre estabilidade dos preços e crescimento da produção. Convém salientar que esse comportamento foi tambèm identificado para as culturas do algodão e do milho.

A politica de crédito rural será a próxima política governamental a ser considerada. Segundo BARROS \& ARAÚJO (1991) o crédito rural è uma fonte financeira importante para complementar os recursos próprios dos agricultores. $\dot{A}$ medida que os agricultores demandam bens de capital e/ou inovações tecnológicas

${ }^{6}$ ) Os produtos analisados foram algodão, arroz, feijão, mandioca, milho e soja. 
para modernizar suas atividades produtivas, geralmente demandam também maior volume de crédito junto aos mercados financeiros. Logo, a demanda de crédito tende a ser derivada da demanda de capital e tecnologia.

Inicialmente o crédito agricola no Brasil era concedido a taxas dé juros que no momento da liquidação dos empréstimos tornavam-se negativas, ou seja, altamente subsidiado. Isso era devido ao aumento da inflação. "Subsídios podem criar distorções, tais como a concentração de crédito e de subsídios, a evasão de recursos para fins não-agricolas, e o emprego inapropriado de fatores produtivos". Esta afirmativa é apresentada por REGO \& WRIGHT (1981) sendo respaldada por vários autores $^{(7)}$. O crédito rural subsidiado ao invés de complementar os recursos utilizados, começa a substituir os recursos próprios, sendo estes aplicados em atividades de menor risco e até no mercado financeiro.

A política de crédito agricola "subsidiado" foi mantida enquanto as autoridades brasileiras achavam que o choque do petróleo ocorrido em 1973 era passageiro, e continuaram de maneira geral com a política econômica do período anterior ao choque. Por outro lado, o choque de 1979 produziu mudanças na politica de crédito. Para (CARVALHO, 1989), o choque de 1979 não só reduziu o crédito subsidiado ao setor agrícola, como também o volume deste crédito. Aparentemente, isto não teria um impacto relevante na produção agrícola já que, no conjunto, a evidência empírica indica que a produção não tem sido significativamente sensivel ao crédito subsidiado. Entretanto, como o crédito é altamente concentrado em poucas culturas de exportação a sua redução pode ter impacto relativamente maior sobre as safras marginais que são basicamente as de alimentos para consumo interno.

Apesar de poucos produtores de mandioca terem acesso ao crédito rural, a redução da disponibilidade de crédito para a essa cultura pode ter levado a duas

( ${ }^{7}$ ) REGO \& WRIGHT (1981) apresentam uma relação de autores que concordam com esta argumentaçäo. 
situações, com impacto negativo no setor. Primeiro, pode ter levado os poucos produtores que utilizavam crédito rural a uma maior utilização de recursos próprios. No caso da mandioca, como na sua maioria são pequenos produtores com baixa capacidade de investimento isso pode ter provocado redução de área e/ou do rendimento físico da cultura. Segundo, pode ter forçado os produtores de mandioca a recorrerem a financiamentos do próprio mercado, logo com taxas irreais para eles. Ou seja, a situação de redução do crédito rural aliada às taxas de retorno historicamente alcançadas pela cultura, pode ter orientado os recursos para as culturas de maiores taxas de retorno.

IBAÑEZ-MEIER et alii (1987) verificaram que a despeito da mandioca ser freqüentemente nomeada uma cultura prioritária, a politica agricola por meio do seu principal instrumento de politica, o crédito rural, não reflete esse discurso. A distribuição média de crédito rural para a mandioca no período de 1975 a 1985 , foi apenas $1,2 \%$, contra $22 \%, 14 \%, 12 \%$ e $11 \%$ recebido respectivamente pelas culturas de soja, arroz, trigo e café.

A situação desfavorável experimentada pela cultura da mandioca com relação ao crédito rural, está inserida na lógica tradicional da forma de orientação do crédito no Brasil, conforme demonstra REGO \& WRIGHT (1981): ao longo da década de 70 houve uma concentração de crédito em grandes estabelecimentos e em culturas que utilizam técnicas intensivas em capital. Fica evidente que dentro destes critérios a cultura da mandioca não se enquadra, pois geralmente é cultivada em pequenas propriedades e com pouco capital.

Utilizada de forma adequada (quantitativa e qualitativamente) não há duvida de que a política de crédito rural pode contribuir positivamente para o aumento da receita agricola. Assim, as distorções existentes na politica de crédito agrícola no Brasil, têm provocado o enfraquecimento econômico dos setores que ficaram à 
margem dessa política, quando comparados relativamente com os setores beneficiados.

O crédito agricola no pais foi implementado de forma orientada, principalmente, para atender aos grandes produtores e às culturas de exportação. Assim, as caracteristicas da mandiocultura, cultivada por pequenos produtores com poucas garantias crediticias, transacionada basicamente no mercado doméstico e com baixo retorno econômico, parece determinar uma posição marginalista da cultura frente à essa política.

A política de mudança tecnológica completa o tripé da política de intervenção governamental no setor agricola brasileiro nos ültimos 30 anos. 0 processo de geração e difusão de tecnologia agricola no Brasil, teve na década de setenta o periodo de maior expansão apoiado na criação do Sistema Nacional de Pesquisa Agropecuária - tendo como órgão central do sistema a Empresa Brasileira de Pesquisa Agropecuária (EMBRAPA) - e no Sistema Brasileiro de Assistência Técnica e Extensão Rural (SIBRATER).

Naquele periodo foi consolidado o processo de modernização da agricultura brasileira. Entretanto, a amplitude do processo não foi de forma generalizada contemplando todos os produtos. Os benefícios da modernização agricola, ou seja, maiores indices de produtividade e menores custos de produção, foram apropriados pelos produtores de mandioca de forma desigual relativamente a outros produtos. Esse fato pode ser explicado pelas razões descritas a seguir e, deve ser considerado num contexto histórico.

Em primeiro lugar, a crença de que, dada a sua rusticidade, a mandioca possuia a capacidade de desenvolver-se bem em condições adversas, fez com que essa cultura tivesse as condições de recursos naturais altamente desfavoráveis. Ou seja, condições em que as pesquisas têm ação limitada na solução do problema, logo colocando a cultura em desvantagem, quando comparada com outros produtos. 
Sobre o tema da limitação das pesquisas $(8)$ agrícolas PAIVA (1990, p. 171) explica: "Não é fácil comprovar que as pesquisas têm ação limitada na solução dos problemas de deficiência dos recursos naturais, terra e clima, para a agricultura; que através delas, mesmo que executadas, segundo normas cientificamente recomendadas, não se consegue necessariamente aumentos de produtividade e reduções de custos na produção agrícola, que são elementos imprescindíveis ao processo econômico".

O segundo aspecto a ser considerado refere-se à alocação dos recursos (humanos, materiais e financeiros), para a geração de tecnologia agrícola. Tradicionalmente os recursos são orientados para os produtos de maiores taxas de retorno, ampliando o hiato existente entre os dois grupos de produtos (de maiores e menores taxas de retorno).

O terceiro ponto, encontra-se na mesma direção do anterior e está relacionado com a capacidade empresarial e a disponibilidade de recursos dos produtores de mandioca. Os produtores vinculados a outros produtos já dispunham de maior capacidade empresarial e recursos disponiveis para adotarem as tecnologias geradas dentro do modelo de desenvolvimento preconizado.

A última razão considerada talvez esteja associada ao próprio desempenho da cultura, concorrendo para que não tenha havido substancial eficiência das indústrias de insumos em oferecer ao setor os equipamentos que poderiam favorecer uma melhor integração agroindustrial e, conseqüentemente, um melhor desempenho. Para exemplificar, pode-se citar a oferta inadequada de máquinas colheitadeiras a exemplo de outras culturas.

$\left.{ }^{8}\right)$ PAIVA (1990), esclarece que no seu trabalho está sendo adotado o conceito restrito de pesquisa. Ou seja, de interesse mais imediato que visa, principalmente, através de experimentos de campo, testar as formas de corrigir as deficiências dos recursos naturais que dificultam ou limitam a modernização da produção agrícola. 
Um aspecto que deve ser considerado na análise das políticas de mudança tecnológica de um produto, diz respeito às suas características microeconômicas. Considerando-se o produto tradicionalmente processado a partir das raizes da mandioca (farinha de mandioca), há um consenso que se trata de um bem de baixa elasticidade-preço da demanda, e nessas condiçōes sabe-se, que tudo mais constante, serão os consumidores os maiores beneficiados de um processo de aumento da produção via adoção de novas tecnologias. Enfatizando a racionalidade dos produtores GARDNER \& OLIVEIRA (1984) relatam: "... devemos lembrar que os produtores, antes de tudo, são homens de negócio e, como tal, sempre procuram (a) evitar riscos quando estão empenhados em maximizar lucros e (b) evitar "desastres" quando estão trabalhando para subsistência". Talvez seja esta uma das explicações para o baixo nível de adoção das tecnologias geradas para a cultura da mandioca.

Os estudos dos impactos do processo de mudança tecnológica geralmente esbarram em um problema. Para MESQUITA (1994), "a principal dificuldade na análise das relações entre a política de mudança tecnológica e o desempenho do setor agricola diz respeito à escolha de um indice ${ }^{9}$ ) que represente de forma satisfatória a evolução da política ou esforço dispendido pelo país para modernizar sua agricultura".

Com relação às políticas de incentivo diferenciado, foram analisados os casos das culturas tradicionalmente beneficiadas, pela política agrícola, a saber, soja, canade-açúcar, milho e outras como concorrentes na produção, e do trigo no consumo.

A opção pela cana-de-açúcar como matéria-prima para produção de álcool após os choques do petróleo, significou a manutenção e/ou ampliação da atividade canavieira em muitas áreas. SILVA (1983) analisando a situação da lavoura canavieira na década de 70 , constata que na segunda metade da década de 70 ,

(9) Para uma discussão detalhada sobre o assunto ver por exemplo SILVA (1984) e MESQUITA (1994). 
sobretudo em São Paulo, o processo de expansão da cana-de-açúcar teve dimensões agigantadas, acarretando modificações consideráveis na estrutura da produção. A dicotomia produtiva foi também uma forma de manifestação da dicotomia tecnológica entre tipos de produtores de cana-de-açúcar, em primeiro plano, e entre produtores de cana, café, cacau e soja, de um lado, e arroz, feijão, milho e mandioca de outro, em plano mais geral.

O referido autor considera que neste periodo reforçou-se a segmentação da agricultura, fenômeno que, longe de ser casual, retratou um histórico dilema de política econômica. Dirigindo-se a mercados diferentes, aqueles grupos de culturas apresentaram comportamento diversos. Em paralelo, a política agricola adotada na época serviu para estimular esta mecânica. No mercado fundiário assistiu-se a incomum valorização das terras, a um só tempo causa e efeito da concentração da propriedade, que trouxe problemas à produção de alimentos.

Outro aspecto a ser considerado com relação ao incentivo dado à atividade canavieira, diz respeito às suas implicações na expansão da fronteira agrícola. Como os preços subsidiados da cana são pelo PROÁLCOOL e proporciona uma maior margem de lucro, os produtores estão ocupando, para produção de cana, as áreas mais nobres e até aquelas próximas dos centros urbanos. Como conseqüencia, os produtos alimentares (bens salários) como, por exemplo, a mandioca, são deslocados para áreas marginais, onde o custo de produção é geralmente maior. Isso, devido à necessidade de maiores investimentos, dadas as condições de recursos naturais nas novas regiões produtoras. Além dos aspectos ligados à necessidade de maiores investimento, adiciona-se o custo de transporte, considerando-se que os produtos alimentares estão agora sendo produzidos em áreas mais distantes dos centros de consumo.

HOMEM DE MELO (1985, p.46) observa que durante o periodo de $77 / 84$, enquanto as áreas cultivadas com produtos alimentares-domésticos e 
exportáveis $(10)$ ficaram estagnadas, aquela dedicada à cana-de-açúcar teve um crescimento de $7,43 \%$ a.a.

A falta de apoio específico ao setor mandioqueiro tem levado a um processo de substituição da cultura da mandioca por outras culturas. Os estudos realizados por RYFF (1988) visando avaliar o impacto provocado pela expansão do cultivo de soja na agricultura do Rio Grande do Sul, indicam que o impacto de expansão da soja, se fez sentir de forma mais acentuada, nos cultivos alimentares como feijão, mandioca, batata-inglesa e banana, observando-se no período de 1964/1981, a redução de área colhida associada à queda ou estagnação na produtividade dessas culturas alimentares. Ryff buscando estabelecer uma relação direta entre a expansão da lavoura de soja e a retração de outras culturas/atividades, no Rio Grande do Sul, analisou especificamente os municipios e microrregiões que mais se destacaram no final de 1975 no plantio de soja. Ele observou que onde a soja mostrou-se mais expressiva, ocorreu redução da área dedicada às demais atividades, com destaque para a criação de gado e os cultivos de milho e mandioca.

A politica de subsídio ao trigo é um dos fatores que tradicionalmente tem sido atribuido como responsável pelo mau desempenho da cultura da mandioca no Brasil(11). GONTIJO et alii (1989) avaliando as conseqüências econômicas da eliminação do subsídio ao trigo, considerando um modelo de mercados múltiplos, observaram repercussões positivas nos preços das culturas sob proteção da política de garantia de preços mínimos (PGPM) ${ }^{(12)}$, com exceção da soja. Segundo esses

$\left({ }^{10}\right)$ HOMEM DE MELO(1985), considera: (i) culturas aliementares-domésticas - arroz, feijão, milho, mandioca e batata; e (ii) culturas exportáveis: algodão, amendoim, cacau, fumo, laranja, e soja.

(11) Ver sobre esse assunto por exemplo IBAÑEZ-MEIER et alii (1987, p.14), LIMA (s.d., p.71), SILVA (1989) e SILVA (1992). "Até 1973 era obrigatória a incorporação de farinha de raspa de mandioca à farinha de trigo usada em panificação. Entretanto, o crescente subsidio do trigo eliminou o seu emprego" (LIMA, op. cit.).

${ }^{12}$ ) Os autores consideraram no grupo de produtos contemplados com a política de garantia de preços mínimos, os següintes produtos: soja, mandioca, feijão, arroz, milho, algodão e carnes. 
autores a interdependência existente entre a cultura do trigo e as culturas amparadas pela PGPM, do lado da produção, determinaria um aumento de quase $5 \%$ nos preços recebidos pelos produtores dessas culturas e uma redução de $0,4 \%$ nos preços reais da soja.

Continuando a análise, os autores observaram que, pelo lado do consumo, "nota-se um aumento nos preços e no consumo dos produtos constantes da pauta de garantia de preços mínimos". Como conclusão, afirmam que o modelo mostrou a influência das alterações efetuadas no mercado tritícola nas culturas sob proteção da PGPM, principalmente a soja.

A suposta correlação negativa entre a política de subsídio ao trigo e o desempenho da cultura da mandioca tem sido, para alguns técnicos e empresários, uma das explicações para a performance do setor. $E$ ao que tudo indica, as mudanças ocorridas na politica do trigo não causaram no setor mandioqueiro, ate o momento, o impacto esperado.

\section{3. Aspectos Relacionados à Demanda de MANDIOCA}

No tocante a demanda de mandioca, os estudos indicam que, prevalecendo o nivel de consumo atual - baseado apenas na farinha - a retomada do crescimento na economia brasileira, acompanhado de uma melhor distribuição de renda, conduzirá a uma redução da demanda pelo produto (HOMEM DE MELO 1988, 1991 e 1994).

Por outro lado, um exame dos estudos citados anteriormente permite uma análise alternativa para as perspectivas da mandioca, em meio à dinâmica da evolução da demanda por alimentos. A referida análise pode ser respaldada no processo de mudança de hábitos de consumo, com predominância das proteinas animais em detrimento dos alimentos calórico, e nas possibilidades da mandioca contribuir para a redução das importações de trigo. 
Analisando-se, especificamente, a mudança de hábitos de consumo da população na direção do consumo de proteinas animais, observa-se que o incremento da produção dessas proteinas vem aumentando rapidamente o consumo de alimentos balanceados para animais. Conseqüentemente, via efeito demanda derivada, afetando a demanda de milho e de outras matérias-primas.

Para atender às necessidades de milho, Homem de Melo estima que a taxa de crescimento da produção desse cereal deve ser maior que a taxa histórica de $3,85 \%$. O autor considera que nesse produto talvez resida o grande desafio da agricultura brasileira nos próximos anos.

Considerando o exposto, admite-se que a mandioca pode constituir uma alternativa viável na substituição de parte do milho, principalmente nas regiões onde ocorrem dificuldades (devido às condições edafo-climáticas) para produzi-lo, e apresentar assim demanda superior às estimadas em estudos anteriores.

Os resultados dos estudos conduzidos por SILVA \& KHAN (1994) revelaram que a substituição de milho por raspa de mandioca em ração suína, no Estado do Ceará, proporciona beneficios para a sociedade cearense como um todo.

Ainda com relação às mudanças nos hábitos de consumo, não podemos deixar de considerar que a demanda de alimentos para a maioria da população brasileira encontra-se, no momento, numa fase mais quantitativa. Mas, já começa a incorporar as tendências mundiais em termos de demanda de alimentos. Por exemplo, o aumento da participação da mulher no mercado de trabalho é um fenômeno inexóravel, logo, o tempo anteriormente dedicado às tradicionais tarefas domésticas está sendo reduzido e exigindo conseqüentemente produtos de preparação mais fáceis. É a chamada "demanda por conveniência". Nesse sentido, apesar de a curto prazo não contribuir de forma significativa, a médio e longo prazos, a produção de mandioca pré-cozida e congelada poderá ampliar a demanda do produto. 
Outra alternativa para mudar as projeções da demanda de mandioca, reside na possibilidade da referida cultura contribuir com a redução das importações de trigo. De acordo com SILVA \& SILVA (1992), "enquanto não existiam protecionismo ao trigo (até 1967), já se misturavam até $25 \%$ de farináceos de mandioca nos do cereal sem alterar as caracteristicas físicas e químicas de alimentos de amplo consumo popular, como pão e macarrão". Os autores revelam que o farináceo de mandioca substitui também a farinha de trigo nas colas das indústrias moveleiras de placas de compensados e de aglomerados de madeiras.

Além das possibilidades arroladas anteriormente a mandioca apresenta potencialidades para participar de outros mercados (Figura 04), 0 amido (independente da sua origem botânica) é tradicionalmente empregado na indústria alimentícia, metalúrgica, mineração, construção, cosmética, farmacêutica, papel e papelão, têxtil, etc. $O$ amido de mandioca $(13)$ por sua proporção entre amilose/amilopectina, pelas características ligações glicosídicas e estrutura granular, apresenta propriedades singulares que o torna preferido em diversos processamentos alimentares e usos industriais (CEREDA, 1989).

Assumindo-se, pois, que a mandioca possa ocupar uma parcela dos mercados alternativos e/ou seja integrada ao "complexo protéico" (efeito demanda derivada) formado por produtos com elevada elasticidade-renda da demanda, podese esperar que o setor venha a apresentar maior dinamismo no futuro.

Com base nesta revisão bibliográfica pode-se observar que exceto os estudos conduzidos por PORTO (1986) e IBAÑEZ-MEIER et alii (1987), os demais não foram orientados especificamente para analisar o desempenho da cultura da mandioca frente às politicas públicas, e mesmo assim, esses estudos utilizaram como procedimento metodológico a análise tabular, havendo a necessidade de um maior

$\left({ }^{13}\right)$ Tecnicamente denominado de fécula e popularmente polvilho. 
aprofundamento das implicações das políticas governamentais no desempenho da cultura considerando-se um periodo mais longo.

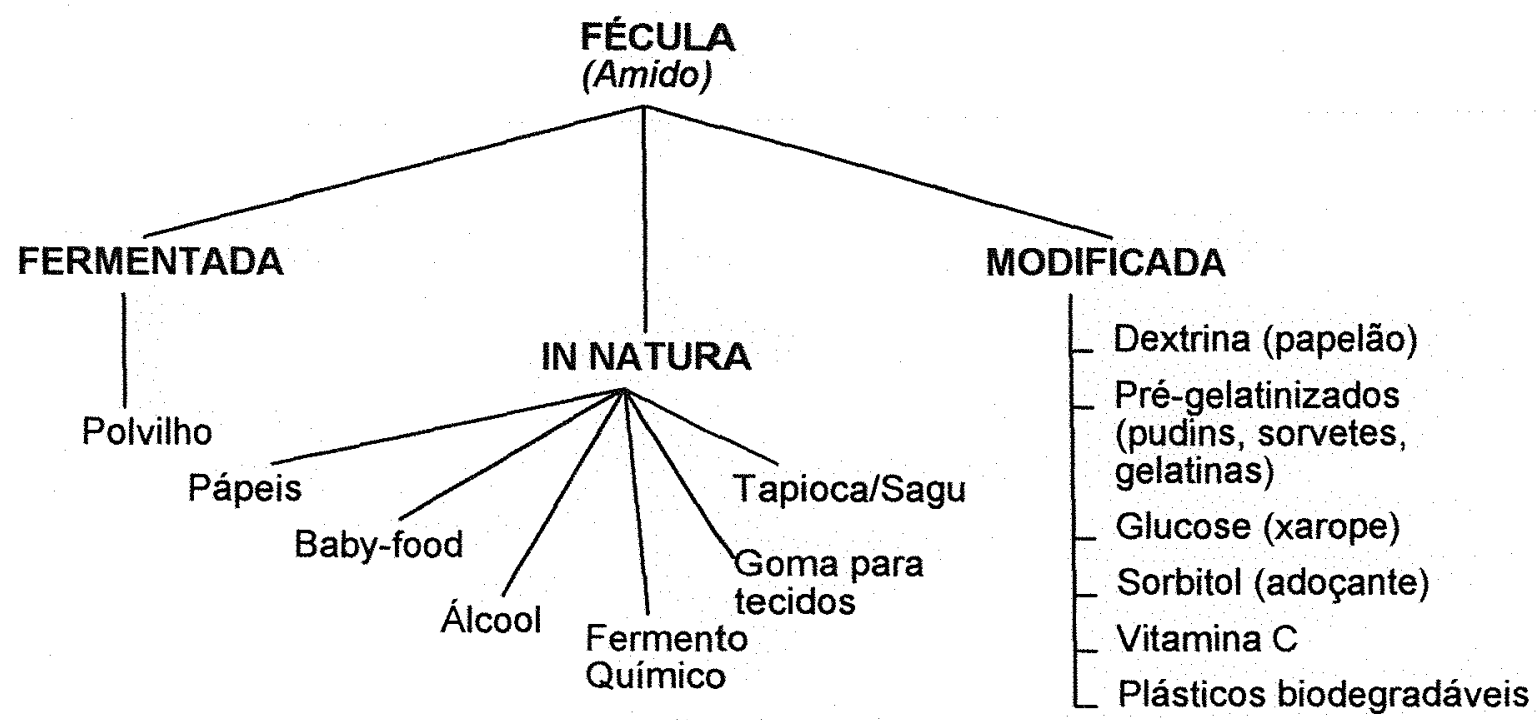

Fonte: VILPOUX (1994)

Figura 04 - Potencialidades de uso do amido no Brasil. 


\section{METODOLOGIA}

\subsection{Considerações teóricas Relativas a Algumas Políticas Públicas}

A agricultura, diferentemente da indústria e do comércio cujo processo produtivo pode ser melhor controlado, sofre influência de diversos fatores: um deles é a dependência dos fatores climáticos e outro é a própria natureza de seu processo biológico. Um terceiro são os efeitos biológicos causados por ataques de pragas e doenças, tornando desta maneira uma atividade de risco e incerteza. Os produtos agricolas são mais pereciveis e, em muitas situações, necessitam de um circulação rápida entre o momento da colheita e do consumo. Às vezes não podem ser armazenados por um período de tempo muito prolongado e, dessa forma, reduz-se o poder de negociação dos produtores na tentativa de conseguir melhores preços.

Outro aspecto importante refere-se à sazonalidade da atividade. $O$ processo produtivo na agricultura não é contínuo, ou seja, a oferta é estacional para uma demanda relativamente constante. Somando ao problema da perecibilidade de muitos produtos agricolas e das limitações no armazenamento, essa situação leva a flutuações drásticas de preços dos produtos.

Diante dessas características, a agricultura requer um tratamento diferenciado por parte dos gestores da política econômica, principalmente quando o produto em questão ainda não alcançou um nivel de modernização compativel com os indicadores internacionais. Do ponto de vista econômico, sabe-se que, geralmente, o setor agrícola responde aos incentivos governamentais. Assim sendo, os produtos 
que recebem incentivos de preço, crédito e de geração de tecnologia, ou de outras políticas - a exemplo do PROÁLCOOL - tornam-se relativamente mais atrativos e podem apresentar melhor desempenho quando comparados com outros produtos, à margem deste processo.

As políticas públicas orientadas para o meio rural podem ser consideradas uma tentativa de compensar as características inerentes à atividade agricola que conferem ao setor uma situação desvantajosa, vis-à-vis, aos demais setores da economia. No caso do Brasil, as políticas agrícolas (muitas vezes) também foram utilizadas como mecanismos compensatórios de outras políticas macroeconómicas utilizadas no país(1).

Nesta seção objetiva-se apresentar a existência, no plano teórico, de relações entre as politicas que serão estudadas e o desempenho do setor mandioqueiro. Inicialmente serão apresentados os aspectos teóricos de cada politica e, posteriormente, serão abordadas, dentro de um perspectiva de interdependência, as politicas estudadas e a tomada de decisão dos produtores de mandioca.

\subsubsection{Política de Preço}

Segundo MENDONÇA DE BARROS (1979), no que tange à política de preços podem-se distinguir três tipos de atividades: (i) preços mínimos; (ii) politicas especiais para certos produtos; e (iii) a politica comercial. Para atender aos nossos objetivos serão enfatizadas as politicas de preços mínimos (PPM) e as politicas especiais para certos produtos. Nesta subseção será considerada apenas a política de preços mínimos; as políticas especiais serão tratadas posteriormente. Não será estudada a política comercial, a qual está mais vinculada à política cambial, por ter pouca relevância para a cultura da mandioca.

(1) Ver por exemplo VEIGA (1974, p. 232). 
Os efeitos danosos relacionados à incerteza e ao risco de preço da atividade agrícola, podem ser reduzidos com um programa de preço minimo que favoreça efetivamente a alocação dos recursos via comportamento dos preços futuros. Sobre a possibilidade do preço mínimo agir como um indicativo do preço futuro LOPES (1978) faz a seguinte consideração: "o preço mínimo é um preço de futuro e, por definição, uma antecipação do preço a vigorar no mercado no período de comercialização (...".

De acordo com OLIVEIRA (1974), os preços minimos podem ser utilizados como instrumento de política agricola visando: (i) proteger a renda do setor agricola; (ii) aumentar a produção da agricultura; ou (iii) eliminar o risco de preço enfrentado pelo produtor.

Observa-se dessa forma que os objetivos da PPM estão concentrados em duas áreas, isto é, alocação de recursos e renda. COELHO (1979) revela que embora o potencial da PPM seja mais reduzido para atender aos objetivos relacionados com a renda $(2)$, ela pode agir no sentido de estabilização, distribuição intersetorial e distribuição intra-setorial da renda. "No caso de estabilização da renda, a baixa elasticidade de demanda de produtos agrícolas faz com que os preços sejam mais instáveis do que a produtividade, portanto a PPM pode contribuir para a obtenção de grau maior de estabilização da renda via estabilização de preços".

Nessa mesma direção, OLIVEIRA (1974) considera que se os preços mínimos forem fixados em algum nivel que chegue a sensibilizar a oferta, tenderão a aumentar a renda do setor agrícola, devido à inelasticidade da demanda.

No tocante à alocação de recursos, COELHO (1979) admite que a PPM pode atuar positivamente em três sentidos: (i) por meio da redução de instabilidade nos

(2) A PPM, em termos de renda pode contribuir apenas para adicionar um grau de estabilidade nos retornos dos agricultores. Complementando, apesar da demanda inelástica para a maioria dos produtos agrícolas, a contribuição da PPM é limitada em termos de estabilização da renda dos produtores (COELHO 1979, p.53). 
preços; (ii) aumentando a capacidade de previsão dos produtores sobre o comportamento futuro dos preços; $e$, (iii) influenciando a formação de expectativas dos agricultores. Dentro dessa perspectiva pode-se admitir que, no Brasil, um dos objetivos da política de preço mínimo é freqüentemente aumentar o nivel de resposta da oferta, dada as dificuldades para se obter estabilização de renda que exige mecanismos mais complexos (COELHO, 1978). Logo, os estudos para avaliação da PPM no Brasil procuram identificar na oferta, as mudanças induzidas pela política adotada. A esse respeito podem ser citados, por exemplo, os estudos realizados por SMITH (1978) e DURAN (1978).

Em trabalho desenvolvido por Smith para avaliar o impacto da PPM no Brasil, no periodo de $1954 / 67$, observa-se que a análise das funções de respostas da oferta indica que os preços mínimos não afetaram significativamente as decisões de produção dos principais produtos alimentares $(3)$ quando isto foi tentado. $O$ autor conclui que a principal implicação dessa observação é que os preços de sustentação, para se tornarem mais efetivos, devem ser orientados para objetivos de longo prazo como redução dos riscos e incertezas de preço da agricultura brasileira. Com relação a esse resultado cabe uma indagação: será que a política foi executada de forma eficiente?

Apesar das evidências empíricas com os dados daquela época (1954/67) não indicarem a existência de causalidade entre a política de preço e a oferta dos produtos analisados, há fortes razões teóricas para se esperar que uma política de preço mínimo - se bem conduzida - possa influenciar na produção dos produtos agrícolas que estão sendo beneficiados.

( $\left.{ }^{3}\right)$ Produtos alimentares analisados na Região Centro-Sul: arroz, algodão, milho, amendoim, soja, farinha de mandioca e feijão. 
A esse respeito DURAN (1978) trabalhando com dados mais recentes (1968/76), usando três modelos $(4)$ e dados de séries temporais e corte seccional para avaliar o impacto da PPM nos produtos arroz, milho e soja nos Estados de Góias, Mato Grosso, Minas Gerais, São Paulo, Paraná e Rio Grande do Sul, chegou a seguinte conclusão: "não há dúvida de que o programa de preços mínimos para lavouras básicas teve, no periodo 1968/76, um impacto positivo em relação aos produtos estudados. $O$ que não fica claro é se este impacto foi igual para todas as culturas".

Observa-se que, em última instância, os efeitos de uma política de garantia de preços será refletido diretamente na quantidade ofertada do produto alvo. A teoria relacionada com a oferta de produtos agrícolas, prevê que quando os produtores decidem o quanto produzir, tomam suas decisões de preços futuros baseados nos preços atuais. Sendo o preço mínimo um indicativo do preço futuro, os produtores devem definir a quantidade plantada em função da expectativa de preço proporcionada pelo preço mínimo. Ou seja, a produção planejada no momento t está em função da expectativa de preço no momento da colheita e/ou do preço mínimo, e, dependedo das elasticidades de oferta e demanda, as flutuações na produção planejada e nos preços apresentarão diferentes magnitudes (de acordo com o teorema da "teia de aranha").

\subsubsection{Política de Crédito}

A política de crédito rural no Brasil, além de outros objetivos, pretendeu oferecer, a exemplo das políticas de preço, de geração e difusão de tecnologia etc,

$\left({ }^{4}\right)$ Modelo 1: (modelo de ajustamento instantâneo) considera que os produtores respondem imediatamente aos preços mínimos como um indicativo do preço futuro. Modelo 2: considera que os produtores se orientam pelos preços mínimos do ano anterior. Modelo 3: modelo do tipo nerloviano, supondo-se que o processo de ajustamento leve mais de um ano. 
uma compensação(5) ao setor agrícola, na forma de uma oferta de capital financeiro em condições mais vantajosas. Buscando-se, assim, reduzir o custo do capital necessário à produção agrícola, de maneira a incentivar a demanda de investimento agrícola e contomar então os problemas referidos anteriormente de baixa rentabilidade, risco e incerteza relativos da agricultura (REZENDE, 1982).

Embora reconhecendo que o crédito rural não deve ser considerado como um insumo(6) na função de produção, a exemplo dos fertilizantes e mão-de-obra, há razões para se aceitar a hipótese de uma relação positiva entre o crédito rural e a oferta de produtos agrícolas.

Os aspectos que impedem de se considerar o crédito rural como fator de produção (insumo) estão associados, principalmente, à eficácia da política. SAYAD (1984) define que a medida de eficácia do crédito representa "quantos cruzeiros dos programas de crédito são efetivamente, e em termos líquidos (...), aplicados no financiamento da produção e dos investimentos do setor agrícola".

A eficácia da política está relacionada com dois problemas. Em primeiro lugar, com as possibilidades de substituição entre os recursos provenientes do crédito rural e de outras formas de financiamento da produção rural. E, em segundo lugar, com a distribuição de crédito entre agricultores com características diferentes (SAYAD op. cit.). Convém salientar que, necessariamente, os dois problemas não são independentes; aqui eles serão tratados de forma isolada apenas para facilitar o seu entendimento.

(5) Conforme discutido anteriormente, durante o processo chamado de politica de substituição de importações implantado no Brasil durante os 15 anos posteriores à Segunda Guerra Mundial, foram utilizados para implementar essa politica uma série de instrumentos. Tais instrumentos provocaram uma acentuada realocação de recursos em favor dos setores secundário e terciário, sendo o setor agrícola penalizado nesse processo. A partir dessa constatação foram utilizadas políticas compensatórias para o setor agrícola. VEIGA (1977) apresenta uma excelente abordagem sobre o assunto. Ver também ARAUJO (1992, p.1).

${ }^{(6)}$ Ver sobre 0 assunto (ADAMS, 1987b, p.98). 
A possibilidade de substituição dos recursos financeiros, é uma característica inerente ao capital financeiro, e é chamada de fungibilidade $(7)$ do dinheiro. Ou seja, "(...) o dinheiro é poder aquisitivo genérico, suscetivel portanto de tomar a forma de qualquer fator de produção, isto é, de ser utilizado em qualquer produção (ou qualquer ativo real ou financeiro)" (REZENDE, op. cit.). Complementando, ALMEIDA (1994) considera que uma unidade monetária tomada por empréstimo é idêntica a uma unidade monetária possuída pelo tomador. $O$ autor conclui que os recursos emprestados podem ser aplicados em qualquer finalidade, independente da originalmente declarada para a obtenção do crédito $(8)$.

SHIROTA (1988) não desconsidera a possibilidade do produtor aplicar os recursos tomados por empréstimo nas atividades agricolas originalmente propostas. Entretanto, pode ocorrer que seja transferida uma parte dos recursos próprios e de terceiros que antes seriam investidos na agricultura, para aquisição de ativos em outros setores. Continuando, Shirota esclarece que esse processo de "(..) substituição será função direta do nivel de acesso do tomador de crédito às fontes alternativas de recursos e das possibilidades de investimentos não-agrícolas".

Quanto ao problema da distribuição do crédito, observa-se que este está fortemente relacionado com os subsídios. SAYAD (op. cit.) revela que, como sabem os economistas e os banqueiros, um contrato de crédito é caracterizado pela taxa de juros, pelo risco da atividade tomadora do empréstimo, e pelas garantias oferecidas ao credor. Para GONZÁLEZ VEGA (1987a), qualquer empréstimo tem três aspectos: seu tamanho, a taxa de juro cobrada e os termos e as condições do contrato de empréstimo a diferentes taxas de juros. É fácil identificar que o custo total para se

(7) Segundo SAYAD (1984 p.99), fungibilidade é a capacidade que tem o capital financeiro que tende a ser aplicado onde obtiver maior rentabilidade. Assim, em condiçóes de juros subsidiados, o crédito rural substitui o capital financeiro do agricultor, que o aplica em outras atividades e não aumenta os investimentos da atividade rural. Ver também sobre 0 assunto VON PISCHKE \& ADAMS (1980).

$\left({ }^{8}\right)$ Ver também sobre o assunto, por exemplo, VON PISCHKE et alii (1983, p.7) e SAYAD (op. cit.). 
transferir os recursos, difere em função da categoria dos tomadores de crédito. Quando são estabelecidos limites para a taxa de juros, os credores (ou seja, as fontes financeiras) procuram combinar o tamanho e as condições do contrato dos empréstimos, visando contrabalançar os efeitos negativos proporcionados pelas taxas de juros menos atrativas.

Em uma condição de crédito subsidiado, são estabelecidas diversas combinações de racionamento do crédito com reflexos danosos, principalmente, para os pequenos produtores de um modo geral, porque possuem menos garantias, e para os produtores das culturas de maior risco, geralmente de subsistencia. $E$ isto está de acordo com os argumentos de SAYAD (op. cit., p. 78), ou seja, "no caso do crédito, o subsídio não está associado à produção agricola diretamente, mas às características dos tomadores e suas propriedades. Assim, a ligação entre subsidio e produção é extremamente tênue, e surgem possibilidades de desvios (...)".

Então, o crédito a taxas preferenciais será alocado com base em critérios que ocasionam impactos desfavoráveis para os pequenos produtores, provocando concentração em favor dos grandes produtores e, como conseqüência, não favorecendo a quem os formuladores de politica "objetivam atender". $E$ isso leva a uma redistribuição ao revés, conforme considerado por GONZÁLEZ VEGA (1987b), acentuando bem mais a concentração da riqueza ao invés de reduzi-la.

Apesar das distorções já evidenciadas pela política de crédito barato, há argumentos a favor do subsídio ao crédito agrícola. Segundo MESQUITA (1994), no Brasil, o principal argumento a favor, relaciona-se com a necessidade de compensar a agricultura pelos efeitos negativos provocados pela politica comercial adotado para o setor. Um outro argumento está relacionado com a contribuição da agricultura no processo de controle da inflação, ou seja, na possibilidade de produzir alimentos a um menor custo, já que os custos de produção seriam menores em presença de taxas preferenciais de juros. 
Anteriormente foi salientado que os problemas relacionados com o processo de substituição e distribuição do crédito não são fenômenos independentes. Para ilustrar esta argumentação, utiliza-se uma revelação bastante esclarecedora apresentada por REZENDE (op. cit.). Segundo o autor, "o custo (ou preço) de uma unidade de capital, relevante para fins de tomada de decisão de investimento na agricultura por parte de um tomador qualquer de crédito rural, não é, em geral, a taxa de juro subsidiada (...), mas sim a maior taxa de retorno que, alternativamente, o tomador poderia obter investindo aquela unidade de capital em outros setores; essa taxa de retorno alternativa funciona como um custo imputado ou implícito, um "custo de oportunidade". Observa-se, neste caso, que a taxa de juro subsidiada, reforçada pelos aspectos da fungibilidade do dinheiro, está se relacionando com a possibilidade de substituição do crédito, e, em última análise, indicando que não se deve considerar o crédito como fator de produção.

Por outro lado, as razões que justifica aceitar a hipótese de uma relação positiva entre o crédito e a oferta de produtos, estão diretamente correlacionadas com a capacidade dos recursos obtidos de terceiros virem ampliar a liquidez dos tomadores de crédito. A esse respeito, ALMEIDA (1994) comenta: "o crédito deve ser visto como meio de aumentar o volume de recursos imediatamente disponiveis".

Nessa mesma direção, LEE et alii (1988) consideram que o potencial para melhorar a renda liquida da fazenda deve ser um fator determinante para a decisão de se usar crédito. Segundo eles, o crédito pode contribuir para melhorar a renda liquida de várias maneiras, tais como:

(1) Criando condições para que a empresa possa expandir suas atividades, obtendo, assim, vantagens com economias de escala;

(2) Incrementando eficiência, ou seja, proporcionando a substituição de recursos, ou melhorando a utilização dos recursos existentes; 
(3) Facilitando o ajustamento da empresa às mudanças econômicas do mercado. Isto é, a necessidade de incorporar uma nova tecnologia, ou mesmo de mudar a atividade da empresa, em face a mudanças no mercado, pode exigir uma mobilização de capital que poderá ser facilitada, com o acesso a fontes de financiamentos externas; $e$,

(4) Melhorando a distribuição do fluxo de caixa. Na atividade agricola diferentemente de outras atividades econômicas, geralmente, não se verifica um fluxo contínuo de renda. Por exemplo, a maioria dos insumos são adquiridos no início do plantio, enquanto que a receita só ocorre após a venda dos produtos. Assim, 0 crédito pode contribuir para melhorar a distribuição do fluxo de caixa e equilibrar gastos e receitas.

GONZÁLEZ VEGA (1987b) proporciona uma outra argumentação onde fica explicita a importância do crédito para a atividade agricola. $O$ autor comenta que a "renda de qualquer produtor está determinada por suas oportunidades produtivas e pelo seu controle sobre os recursos que the permite aproveitar essas oportunidades". E segundo ele, "o controle sobre os insumos requeridos, depende da disponibilidade inicial de recursos próprios do produtor, resultado de seus esforços prévios de poupar, e de seu acesso a recursos externos à sua empresa, por meio do crédito". Assim o acesso ao crédito resulta em uma pré-condição crucial para que muitos produtores possam aproveitar as suas oportunidades de inversões.

ADAMS (1987a) menciona uma série de formas em que o sistema financeiro pode influenciar no desenvolvimento. Para isso, o autor se apoia em algumas vantagens provenientes do processo de intermediação financeira, que por extensão também podem ser atribuidas ao crédito. Dentre elas, cita-se uma que está relacionada especificamente com a atividade rural. Para ele, devido aos riscos inerentes à produção agrícola, os empréstimos tomados no mercado podem facilitar o manejo das alternativas utilizadas para se minimizar os efeitos dos problemas 
climáticos ou de qualquer outra fonte de instabilidade. Patrick, citado por MESQUITA (1994), comenta que para muitos empresários a ausência de restrições quanto a recursos pode ser mais importante do que a redução nos custos.

Para finalizar, inclui-se mais uma consideração que demonstra a importância do crédito para a atividade agricola. NAKANO (1992) revela que "(...) o capital de giro é um fator de produção vital nesta atividade e o volume de recursos necessário por unidade de valor gerada é maior, e por um prazo médio mais longo, do que na indústria. Isto significa que o volume de crédito pode ser um fator restritivo da area plantada se o agricultor não tiver recursos próprios".

Neste trabalho, novamente, embora admitindo-se as dificuldades de se estabelecer uma relação positiva entre crédito rural e produção, em virtude das razões expostas acima, pressupõe-se que o crédito rural formal possa funcionar como "(...) uma fonte financeira importante para complementar os recursos próprios dos agricultores", conforme BARROS \& ARAÚJO (op. cit.). Ou seja, o crédito será considerado como um meio para melhorar a liquidez dos produtores e, nesse sentido pode-se aceitar uma relação positiva entre crédito e oferta de produtos agrícolas.

\subsubsection{Política de Mudança Tecnológica}

Independente do modelo de desenvolvimento agrícola, o processo de crescimento da agricultura é facilitado pelos investimentos em pesquisa tecnológica visando desenvolver novas tecnologias e proporcionar o crescimento da produção.

Esta parte do trabalho não pretende apresentar uma revisão das teorias de desenvolvimento agrícola amplamente explorada na literatura especializada sobre desenvolvimento econômico $(9)$. Entretanto, procura-se evidenciar a importancia da

\footnotetext{
( ) Ver por exemplo Johnston \& Mellor, Hayami \& Ruttan e Schuh citado por SHIROTA (1988).
} 
tecnologia para o desempenho do setor agricola, considerando os modelos de desenvolvimento agrícola mais importantes $(10)$.

BACHA (1992) estudou 13 modelos de análise dos impactos de mudança tecnológica no comportamento do setor agrícola visando classificá-los em modelo de geração ou de difusão de inovações. Os resultados mostram que os modelos do impacto urbano-industrial, de difusão e o mecanismo de autocontrole de Ruy Miller Paiva podem ser classificados como de difusão de tecnologia. Mas, mesmo nesses modelos - exceto o modelo do mecanismo do autocontrole de Ruy Miller Paiva, que considera a tecnologia como dada - o papel da geração de tecnologia não deixa ser evidenciado como componente importante para o processo de desenvolvimento, conforme será melhor explicitado a seguir.

No modelo inspirado nas idéias de Johann Heinrich von Thünen, conhecido como modelo de localização ou do impacto urbano-industrial, a importância da pesquisa pode ser observada, nas justificativas apresentadas por Nicholls, sobre a limitação do impacto do desenvolvimento urbano-industrial de São Paulo, para exercer uma influência independente sobre a produtividade da mão-de-obra na cafeicultura paulista. Como consequência isso iria facilitar o fluxo de capital para dentro, e de mão-de-obra para fora da agricultura. Nicholls conclui que: "O impacto urbano-industrial era, entretanto, limitado, devido à localização de oportunidades econômicas, baseadas em recursos, e a falha do governo brasileiro em investir na pesquisa(11) e nos serviços agricolas necessários para permitir ao setor acompanhar o crescimento urbano-industrial" (HAYAMI \& RUTTAN, 1988).

Em outra passagem, esses autores revelam que as politicas de desenvolvimento baseadas no modelo do impacto urbano-industrial parecem ter alcance limitado nos países menos desenvolvidos. Dentre outros fatores, contribuem

(10) A exposição a seguir, está baseada, principalmente, em HAYAMI \& RUTTAN (1988).

(11) O grifo é nosso. 
para isso, a não disponibilidade de tecnologia necessária para o rápido crescimento agrícola.

O modelo de difusão talvez seja aquele que dá menor ênfase ao papel da geração de tecnologia agricola no processo de desenvolvimento econômico. Os adeptos do modelo pressupõem que as disparidades substanciais na produtividade da terra ou mão-de-obra entre produtores com a mesma dotação de recursos naturais, é explicada pela posse e utilização dos outros fatores de produção. Logo, se esses fatores forem difundidos, haverá uma diminuição na dispersão da produtividade entre eles. Esse modelo parte da hipótese de que o estoque de tecnologias seja suficiente para alavancar o processo de desenvolvimento, restando apenas difundi-las e determinar a melhor forma de alocação dos recursos.

Dentre outros aspectos limitantes, o modelo de difusão implica que o processo de desenvolvimento da agricultura depende tão somente do potencial da disseminação das tecnologias disponíveis. Isso provocou um certo desequilibrio entre a oferta e demanda de tecnologia, uma vez que a ênfase dada ao estoque de tecnologia não levou em consideração a sua demanda no médio e longo prazos. Isto demonstra que mesmo nos modelos da corrente do difusionismo, não se pode relegar o papel da pesquisa para o desenvolvimento agrícola.

Nos modelos em que se pressupõe a transferência de mão-de-obra do setor agricola para o setor industrial, classificados de duais dinâmicos $(12)$ por HAYAMI \& RUTTAN (1988), o mecanismo que permite uma realocação continua da mão-de-obra entre os dois setores está baseado no aumento da produtividade na agricultura. $\mathrm{O}$ excedente agrícola que precisa ser gerado, sem comprometer os termos de troca contra o setor urbano-industrial, pode ser obtido, dentre outras formas, por meio do aumento da taxa de progresso técnico na agricultura. De um modo geral, esse aumento que resulta em incremento de produtividade, é obtido com grande salto

(12) Ver também sobre o tema FEI \& RANIS (1975), JORGENSON (1975) e BACHA (1992). 
tecnológico. É patente o reconhecimento da importância do aumento da produção e da produtividade para o crescimento econômico em geral, sustentado nos avanços tecnológicos.

Tanto nos modelos de exploração de recursos, que inclui os modelos das matérias-primas e excedente exportável, como no modelo de conservação, os recursos naturais disponiveis assumem papel importante(13). É fácil perceber que a elasticidade dos recursos é limitada, e assim, a incorporação de novas áreas ao processo produtivo, baseado exclusivamente no potencial de recursos, vai, no decorrer do tempo, depender do desenvolvimento de tecnologias para solucionar os problemas identificados nas áreas novas, considerando-se as limitações da fronteira agricola. Segundo BACHA (1992, p.49), o modelo de conservação pretendeu ser um modelo de geração de tecnologia, que utiliza recursos internos às propriedades agrícolas.

O modelo de insumo moderno é uma alternativa ao modelo de difusão diante da inadequação das políticas que nele se baseavam, ou seja, que enfatizavam o potencial do estoque de tecnologias. Esse modelo foi apresentado por Schultz, em seu livro "Transforming Traditional Agriculture", e possui dois aspectos básicos: Em primeiro lugar, é a tomada de consciência de que "(...) os ganhos obtidos com a simples realocação de recursos, embora reais, são limitados e insuficiente para fazer face às exigências do crescimento econômico nos paises pouco desenvolvidos; além disto, constatou-se também que a transferência de tecnologias entre países nem sempre é possivel, dadas as caracteristicas da produção agricola, principalmente sua grande dependência com relação às condições ambientais" (MESQUITA, 1994). E em segundo lugar, è que "(..) os camponeses na agricultura tradicional, alocam seus recursos de forma racional e eficientemente, e permanecem pobres porque, na recursos naturais nos modelos citados. 
maioria dos países pobres, há apenas oportunidades técnicas e econômicas limitadas às quais podem responder" [Schultz citado por HAYAMI \& RUTTAN (1988)].

"Na opinião de Schultz, a chave para transformar um setor agricola tradicional numa fonte produtiva de crescimento econômico é o investimento, para tornar os insumos modernos disponiveis aos agricultores em paises pobres" (HAYAMI \& RUTTAN, 1988). Schultz conclui que tais investimentos devem ser orientados, dentre outros, para: "aumentar a capacidade da pesquisa agrícola produzir novos conhecimentos técnicos" (grifo nosso) [Schultz citado por BACHA (1992)].

De acordo com BACHA (1992), "o modelo dos insumos modernos pretende ser um modelo de geração e de difusão de tecnologia. Esse modelo não específica o processo pelo qual as relações de preços de fatores e de produtos induzem ao investimento da pesquisa em certa direção".

Segundo HAYAMI \& RUTTAN (1988), uma teoria de desenvolvimento agricola deve incorporar o mecanismo pelo qual uma sociedade escolhe o caminho ótimo de mudança tecnológica para a agricultura. Os autores consideram que a teoria das inovações induzidas representa um esforço para interpretar o processo de mudança técnica como endógeno ao sistema econômico. Ou seja, assumindo que a mudança técnica representa uma resposta dinâmica às mudanças na disponibilidade de recursos (efeito dos preços relativos dos fatores) e ao crescimento da demanda (efeito nos preços dos produtos). Esses autores reconhecem que a mudança técnica na agricultura reflete, além dos efeitos da dotação de recursos e o crescimento da demanda, o progresso na ciência em geral e na tecnologia.

De acordo com a classificação proposta por BACHA (1992), o modelo das inovações induzidas é um modelo de geração de tecnologia, em que esta surge, principalmente, por forças endógenas ao setor agrícola.

Quando a inovação é induzida no setor privado, as firmas competitivas atuam racionalmente ao alocar fundos para o desenvolvimento de uma tecnologia que 
facilite a substituição de fatores mais caros pelo menos caros. A inovação técnica gerada pelo setor público é induzida pela dotação de fatores que se manifestam pelos preços de mercado. Estes induzem os agricultores a pressionar por tecnologias que utilizem os recursos abundantes e menos os recursos escassos, conforme explica Hayami \& Ruttan [citado por BACHA (1992)].

Concluindo, observa-se que independente da trajetória da mudança tecnológica na agricultura, se orientada para avanços nas tecnologias biológicas ou nas tecnologias mecânicas, parece razoável considerar que as novas técnicas culturais, ou as novas sementes, ou os novos processos de mecanização, facilitam o desenvolvimento agricola e são fatores determinantes no desempenho dos diferentes produtos.

Nessa mesma direção ARAÚJO (1975) considera que o "(...) aumento da produção e/ou produtividade agricola exige, na maioria dos casos, uma combinação de mudança no nivel de tecnologia, reformas institucionais e grande inversões de capital, estas últimas dentro e fora do setor primário".

\subsubsection{Políticas de incentivos diferenciados}

Os aspectos teóricos referentes às políticas de incentivo diferenciado ou especiais, estão inseridos nas discussões anteriores, uma vez que se trata apenas de um conjunto de diretrizes e ações orientadas especificamente para atender um determinado produto. Esses programas especiais, como foi por exemplo, os casos do PROÁLCOOL e da politica do trigo, passaram necessariamente pelas políticas de preço, de crédito e de mudança tecnológica. Por isso, não cabe no escopo desse trabalho uma discussão exclusiva a respeito das politicas de incentivo diferenciado. 


\subsubsection{As Políticas Públicas e sua Relação com a Tomada de Decisão dos Produtores de Mandioca}

Inicialmente, faz-se necessário esclarecer que os produtores de mandioca, longe de formarem um grupo homogêneo, apresentam caracteristicas distintas que dependem de sua forma de inserção no mercado e dos objetivos da produção.

Em uma caracterização dos sistemas produtivos da mandioca, evidencia-se a existência de dois grupos de produtores bem definidos. $O$ primeiro é formado por pequenos e médios produtores onde 0 produto é cultivado para subsistência e, conseqüentemente, a comercializção é feita somente com o excedente da produção. Para esse grupo, a mandioca desempenha um importante papel na estratégia de segurança alimentar para as unidades de produção do tipo familiar. A cultura, além de ser importante como fonte de carboidrato para a alimentação humana, é utilizada também na alimentação dos pequenos rebanhos (bovino, suíno e avícola), que são elementos significativos na composição da renda nessas unidades de produção. O segundo grupo possui uma postura mais empresarial, cultiva geralmente áreas maiores em comparação com o grupo anterior, e está perfeitamente integrado ao mercado.

Do ponto de vista do processamento, o primeiro grupo concentra o processo nas indústrias artesanais e de pequeno e médio porte. Já, o segundo grupo utiliza indústrias de grande porte com equipamentos altamente sofisticados e com tecnologia semelhante à utilizada em nivel internacional, como centrifugas e peneiras cônicas rotativas, que substituiram as peneiras cilindricas (CEREDA, 1990).

Em termos regionais, grosso modo, pode-se afirmar que os produtores do primeiro grupo estão mais concentrados nas Regiões Norte e Nordeste, enquanto os do segundo grupo na Região Centro-Sul (englobando as demais regiões fisiográficas). 
Uma outra diferença importante entre os dois grupos de produtores, localizase no acesso aos recursos naturais e na utilização da mão-de-obra. É razoável considerar que o primeiro grupo sofre maiores restrições ambientais e usam geralmente mão-de-obra familiar.

Essa tentativa de tipificar os produtores de mandioca tem como objetivo facilitar a identificação dos fatores determinantes da tomada de decisão desses produtores e, conseqüentemente, verificar as relações entre as políticas públicas e o desempenho do setor mandioqueiro no Brasil.

Independente do grupo a que eles pertencem pode-se aceitar que os produtores de mandioca levem em consideração o comportamento dos preços como variável importante para a decisão do quanto produzir. Mesmo no caso de subsistência o excesso de produção é colocado no mecado. Por isso, assumindo que - preço mínimo é um indicativo do preço futuro, conforme os autores citados anteriormente (seção 4.1.1), ele deve ter influência no desempenho do setor.

A análise das relações entre a politica de crédito rural e as decisões dos produtores de mandioca deve focalizar, ao menos, dois aspectos: os relacionados aos "desvios" nas aplicações e à distribuição dos recursos. Esses "desvios" devem ser entendidos muito mais como um processo de substituição do capital financeiro do agricultor pelo crédito rural, conforme explicado na seção precedente. E ele está diretamente ligado ao caráter fungivel do dinheiro. Assim sendo, os poucos produtores de mandioca que tiveram acesso ao crédito rural, em função da baixa rentabilidade da atividade, podem ter tomado a decisão de "desviar" os recursos para atividades mais rentáveis, numa proporção superior aos produtores de outras culturas. Convém salientar que a comprovação empirica desta hipótese é bastante dificil. 
Com relação a distribuição dos recursos, há um consenso entre diversos autores que houve uma concentração na direção dos grandes produtores e das culturas com maior lucratividade, caracteristicas certamente não compartilhada pela cultura da mandioca. Concluindo, pode-se considerar que em uma conjuntura de racionamento de crédito - que é uma das causas da concentração - os produtores que porventura sejam beneficiados, tomam decisão no sentido dos produtos de maior rentabilidade, ampliando as disparidades entre as culturas de maior retorno e a mandioca, aumentando assim, o processo de concentração do crédito rural em favor das culturas mais lucrativas.

A próxima política a ser considerada é a de mudança tecnológica. Em primeiro lugar, parece aceitável que o processo de geração e adoção de tecnologia tem um potencial considerável para solucionar problemas de produção e preço de alimentos.

A tomada de decisão do conjunto dos produtores de mandioca, em face a oferta de tecnologias proporcionada pela política de mudança tecnológica do produto, deve ser considerada dentro dos aspectos referentes aos ambientes agroclimáticos dos mandiocultores e das características microeconômicas do produto (elasticidadepreço da demanda).

No tocante ao ambiente agroclimático, HOMEM DE MELO (1980) menciona que ainda que a tecnologia possa estar igualmente disponivel a todos os agricultores, os beneficios proporcionado pelas novas tecnologias agrícolas não são necessariamente iguais entre os agricultores, estando estes, limitado às condições de solo e clima de cada agricultor específico, sendo portanto, importante a localização dos agricultores para uma maior participação nos beneficios. Assim, um produtor estará mais susceptivel a adotar uma dada tecnologia(14), ceteris paribus, se sua agroambientais. 
condição agroambiental for potencialmente capaz de responder ao investimento na referida tecnologia.

Para a cultura da mandioca, observa-se que em função da baixa rentabilidade da atividade e/ou impotência dos produtores, geralmente, são utilizadas as áreas com menor potencial agroambiental, logo com baixo potencial para responder aos investimentos em tecnologias.

Os aspectos microeconômicos estão associados a uma das caracteristicas da cultura da mandioca como um todo e de um de seus produtos derivados, a farinha. Isto significa possuir baixa elasticidade-preço da demanda. Para os produtos com demanda inelástica, os ganhos econômicos advindos de novas tecnologias que aumentem a oferta, são apropriados em parcela bem maior pelos consumidores, uma vez que aumentos na quantidade são acompanhados por variações maiores nos preços, no sentido contrário, e conseqüentemente na renda.

Diante dessas considerações a respeito da politica de mudança tecnológica e tendo como referencial a tomada de decisão do conjunto dos produtores de mandioca, espera-se que os efeitos dessa politica seja refletido diretamente no comportamento do rendimento físico por unidade de área apresentado pela cultura.

Apesar de não estar diretamente relacionado com uma politica pública dirigida para o setor agrícola, os produtores de mandioca, como era de se esperar, incluem na sua matriz de tomada de decisão os custos de produção da atividade, dando ênfase ao custo da mão-de-obra rural e a disponibilidade de manivas-sementes para o plantio.

O custo da mão-de-obra rural influencia os produtores de mandioca de duas formas. Primeiro, devido à escassez de capital financeiro próprio e às dificuldades de acesso ao crédito - já discutido. Desta forma, em uma situação de aumento nos preços da mão-de-obra, os produtores podem reduzir a área plantada ou deixar de 
executar parte dos tratos culturais recomendados. Isso em função da impossibilidade de contratar mão-de-obra, o que em última instância irá levar a redução da produção.

A segunda forma está relacionada com o custo de oportunidade da mão-deobra disponivel na unidade de produção familiar. O produtor de subsisiência, em geral, aloca a mão-de-obra disponivel na sua unidade de produção para produzir um dado bem de consumo (produto agricola) até o limite em que as suas necessidades sejam atendidas e, se o excedente proporcionado pelo emprego da mão-de-obra na propriedade for maior do que ele poderia ganhar no mercado de trabalho. Em outras palavras, em ambas situações, o aquecimento do mercado de trabalho pode levar aos produtores de mandioca a tomarem a decisão de reduzir a área e/ou os tratos culturais, pois, o componente mão-de-obra tem participação significativa nos custos de produção.

Com relação à disponibilidade de manivas-sementes, observa-se que esse problema é maior para os produtores mais tradicionais. Ela reflete uma dificuldade de manejar corretamente o processo produtivo e está associada aos períodos de seca verificado, principalmente, na Região Nordeste. Após os longos períodos de estiagem observa-se um déficit de material para o plantio, pois as ramas (incluindo parte aérea e caule - manivas) são utilizadas no arraçoamento animal, causando a falta de material para plantio e a conseqüente limitação da área plantada nas safras seguintes.

Até o momento foram examinados aspectos do lado da produção. Mas, não se pode desconsiderar que as decisões dos produtores são influenciadas pelo comportamento da demanda dos produtos. A implantação da politica de subsídio ao trigo, no inicio dos anos setenta, foi responsável pela mudança nos hábitos alimentares da grande maioria da população brasileira situada nas classes de renda mais baixas. Tomando-se os resultados encontrados por SILVA (1991) para ilustrar 
essa afirmação, verifica-se que em termos do consumo total por classe de renda populacional, as classes que mais absorveram os derivados do trigo e, portanto, 0 subsidio ao consumo, foram as classes de renda familiar baixa - de 2 a 6 salários que é a classe modal(15). Convém salientar que nessas classes de renda concentrase o consumo de mandioca e derivados, conforme os dados do ENDEF e da POF.

Como exemplo do impacto provocado pela política de subsídio ao trigo, COCK \& LYNAM (1991) revelam que nos Estados de São Paulo, Rio de Janeiro e Minas Gerais o uso de farinha de mandioca em produtos panificáveis aumentou de 50 mil toneladas em 1967 para 180 mil toneladas em 1975. Com a implementação da política de subsídio, a farinha panificável de mandioca deixou de ser competitiva e, só no Estado de São Paulo, na década de setenta, foram fechadas aproximadamente 300 plantas processadoras do produto.

Ainda considerando os aspectos ligados aos produtos concorrentes da mandioca, antes do subsidio ao trigo, o padrão de consumo relacionado com o produto, na Região Sul do Brasil, era diferente do atual. A esse respeito, Cock \& Lynam (p.20) dizem:

\footnotetext{
"A causa de los grandes subsidios para el trigo en los años setenta, la yuca, que se usaba exclusivamente como alimento humano, se destinó más a la alimentación de cerdos en la fincas donde se producia el cultivo".
}

Esses autores informam que com base em dados primários, mais de $80 \%$ da produção de mandioca na Região Sul é utilizado na alimentação animal e, nesse mercado regional, há um competição direta com o milho.

(15) Os resultados são para o Municipio de São Paulo, mas o autor ressalva que o padrão semelhante pode ser considerado representativo das diversas regiöes do pais. 
A partir dessas considerações a respeito da politica de subsidio ao trigo e do comportamento do consumo do milho, parece ser mais razoável aceitar que os produtores de mandioca da Região Centro-Sul foram os mais afetados pela referida política e pelo comportamento dos preços do milho. Assim, os preços dos produtos concorrentes da mandioca no consumo (trigo e milho), provavelmente fazem parte do cenário de tomada de decisão dos produtores dessa Região.

\subsection{Fatores Associados à Produção de mandioca: Modelo analítico}

As considerações teóricas referentes às politicas públicas delineadas nas seções anteriores, assim como as reflexões a respeito das inter-relações entre as politicas públicas e a tomada de decisão dos produtores de mandioca, sugerem a formulação do modelo analítico apresentado a seguir.

Em primeiro lugar, parece razoável considerar que a produção de mandioca está tradicionalmente associada a pelo menos dois grupos de produtores. Esses grupos possuem caracteristicas diferenciadas já apresentadas anteriormente na seção 4.1.5. e que estäo agora agrupadas na Tabela 4. Diante dessa constatação, não se pode negar que a análise dos fatores correlacionados com a produção de mandioca, passam necessariamente pela avaliação do comportamento das diferentes variáveis envolvidas no processo produtivo individual de ambos grupos de produtores. Ou seja, uma análise para o Grupo I e outra para o Grupo II.

Em segundo lugar, considera-se que os produtores de mandioca comportamse racionalmente. Em outras palavras, no caso dos produtores que orientam a sua produção para o mercado, o objetivo inicial é maximizar o lucro. Já no caso dos produtores de subsistência, primeiro é necessário garantir um nivel mínimo de 
consumo, sendo apenas o excedente colocado no mercado. Em ambos os casos, fica claro que o mercado faz parte do cenário de tomada decisão dos produtores. Ademais, como se está trabalhando com um produto agricola praticamente homogêneo, produzido e consumido por um grande número de agentes e que não oferece barreiras à entrada de novos produtores, pode-se aceitar o pressuposto de que o mercado - no caso da mandioca - aproxima-se de uma estrutura concorrencial.

Tabela 4 - Caracteristicas básicas dos grupos de produtores de mandioca, Brasil.

Grupo de Produtores
Pequenos e médios produtores produzindo, geralmente,
para subsistência e comercializando o excedente. A
cultura desempenha importante papel na estratégia de
segurança alimentar e renda. O processamento é
concentrado nas indústrias artesanais e de pequeno e
médio porte. Localizam-se em regiōes com maiores
restrições ambientais. Usam quase sempre mão-de-obra
familiar. E, concentram-se nas Regiōes Norte e Nordeste.
Cultivam geralmente área maiores do que os produtores
do Grupo I. O objetivo principal é o mercado. O
processamento se dá em indústrias maiores, com
equipamento e tecnologia mais sofisticada. Os produtores
desse grupo estão localizados em regiōes mais propicias
à produção agrícola. Usam mão-de-obra assalariada no
processo de produção. E, concentram-se na Região
Centro-Sul.

Fonte: Dados da pesquisa

Por último, mas não menos importante, pressupõe-se que as políticas governamentais, em última análise, influencia a oferta dos produtos. Essa influência é exercida diretamente por meio dos diferente fatores determinantes da oferta. Por sua 
vez, a oferta dependerá, além do preço do próprio bem, dos preços dos recursos usados na sua produção, dos preços dos demais produtos e das técnicas disponiveis.

Utilizando uma linguagem matemática simples, pode-se sintetizar estas relações da seguinte forma:

$$
Q_{x}=f\left(P_{x}, W_{i}, \pi, T\right)
$$

onde:

$Q_{x}=$ quantidade ofertada(16) do bem $x$;

$P_{x}=$ preço do bem $x$

$\mathrm{W}_{\mathrm{i}}=\left(w_{1}, w_{2}, \ldots w_{n}\right)$, onde $w_{i}$ é o preço do fator de produção $i$

$\pi_{j}=\left(\pi_{1}, \pi_{2}, \ldots \pi_{m}\right)$, onde $\pi_{j}$ é o preço do produto concorrente $j ; \mathrm{e}$

$T=$ tecnologia disponivel.

Como está sendo realizado um estudo do lado da oferta, o comportamento individual das unidades produtivas - das firmas - deve ser levado em consideração. Assim sendo, assume-se que o mecanismo utilizado para a tomada de decisão dos produtores de mandioca segue os princípios básicos da Teoria da Firma e, a quantidade ofertada será considerada como produção.

A partir destas considerações são propostos dois modelos analitico, sendo um para o Grupo I (modelo I) e outro para o Grupo II (modelo II).

O modelo I pode ser representado da seguinte maneira:

$$
Q^{I}=f\left(P^{I}, I^{I}, T^{I}, C^{I}, L^{I}\right)
$$

onde:

$\left({ }^{16}\right)$ Neste trabalho, as expressões "quantidade ofertada" e "produção" serão usadas como sinônimos 
a) $Q^{I}=$ indicador da quantidade ofertada de mandioca pelos produtores do Grupo I;

b) $P^{I}=$ indicador de comportamento do preço. Apesar dos produtores desse grupo orientarem a produção para a subsistência, o preço de mercado é capaz de estimulá-los, pelo menos, no segmento da curva de oferta do produto com comportamento menos inelástico. Para esses produtores, pode-se considerar que em uma determinada faixa de preço, a oferta é pouco sensivel às mudanças nos mesmos. Assim, se a produção apresentar sensibilidade a esse indicador, será provavelmente por conta da resposta dos produtores que estão operando na faixa menos inelástica da curva de oferta do produto. Por isso, considera-se o preço como uma variável importante para esses produtores;

c) $I^{I}=$ indicador de preço dos fatores de produção (insumos). Ceteris paribus, a oferta estará correlacionada negativamente com esse indicador. Na impossibilidade de se contemplar o preço de todos os fatores de produção é aceitável considerar ao menos o preço dos componentes de maior participação nos custos;

d) $T^{I}=$ indicador de mudança tecnológica. Como os produtores do Grupo I, estão submetidos a maiores restrições ambientais, espera-se que no longo prazo, resolvidos os problemas tecnológicos desse espaço agroambiental, a oferta de mandioca será aumentada. A oferta do produto deve-se relacionar positivamente com o referido indicador.

e) $C^{I}=$ indicador de condições climáticas. Esse indicador tem como objetivo captar as condicioções pluviométricas favoráveis à implantação e a condução da cultura. Não se deve esquecer que os produtores do Grupo I estão concentrados nas Regiões Norte e Nordeste. Espera- 
se que a oferta também se relacione positivamente com esse indicador. Condições climáticas adversas, tudo mais constante, devem proporcionar redução da produção e, aumento da produção caso contrário;

f) $L^{I}$ = indicador de liquidez. As considerações efetuadas para o indicador de comportamento do preço, são válidas, em parte, para esse indicador. Justifica-se o presente indicador, pelo fato de que no espaço regional onde se concentra os produtores do Grupo I, observa-se, geralmente, uma participação não desprezivel na parcela do crédito rural. Por outro lado, considerando-se que o montante de recurso aplicado é pouco relevante para o volume de produção da Região, espera-se que 0 indicador tenha uma pequena influência sobre a oferta do produto.

Quanto ao modelo II, este incorpora as seguintes variáveis:

$$
Q^{I I}=f\left(P^{I I}, I^{I I}, T^{I I}, L^{I I}, R^{I I}, D^{I I}\right)
$$

onde:

a) $Q^{I I}=$ indicador da quantidade ofertada de mandioca pelos produtores do Grupo II;

b) $P^{I I}=$ indicador de comportamento do preço. Para esse grupo de produtores, o preço de mercado, assim como o preço mínimo, desempenha um papel fundamental na tomada de decisão, pois o objetivo principal é a colocação do produto no mercado;

c) $I^{I I}=$ indicador de preço dos fatores de produção (insumos). Semelhante ao comportamento pressuposto no Grupo I, a oferta deverá está 
negativamente correlacionada com esse indicador. Entretanto, os fatores considerados nesta situação deverão ser diferentes da situação anterior (Grupo I);

d) $T^{I I}=$ indicador de mudança tecnológica. Esse indicador deve correlacionar-se positivamente com a oferta. Para os produtores desse grupo os quais têm como objetivo principal o mercado, parece razoável atribuir ao componente tecnológico uma importante participação nas mudanças da oferta;

e) $L^{I I}=$ indicador de liquidez. Possivelmente os produtores do Grupo II sejam os mais sensíveis a esse indicador. Espera-se uma relação positiva entre a oferta e o respectivo indicador;

f) $R^{I I}=$ indicador de preço de produtos concorrentes. Esse indicador tem como objetivo captar o comportamento da oferta de mandioca, na situação em que o seu preço permaneceu inalterado e os preços dos demais produtos subiram. A oferta deve se relacionar negativamente com esse indicador;

g) $D^{I I}=$ indicador de preço de produtos derivados. De acordo com as características básicas dos produtores do Grupo II, constata-se que os mesmos estão concentrados na Região Centro-Sul. Entretanto, na sua tomada de decisão esses produtores levam em consideração o comportamento dos preços dos produtos derivados (farinha) na Região Nordeste. Assim sendo, a oferta será positivamente estimulada pelo comportamento dos preços dos produtos derivados naquela Região.

A partir destes modelos analíticos propõe-se os modelos operacionais, os quais são mais apropriados para os testes empíricos. 


\subsection{MODELO EMPIRICO}

A estrutura desenvolvida na seção anterior permite a proposição dos modelos operacionais. Esses modelos serão especificados de tal forma que seja possível a avaliação dos efeitos relativos das diferentes políticas públicas sobre o desempenho da cultura da mandioca.

Neste trabalho, os modelos operacionais empregados são baseados nas variáveis relevantes que influenciam o nivel de produção de mandioca, tendo-se como pressuposto subjacente a racionalidade de decidir qual a melhor forma de combinar vários insumos para produzir um determinado produto de um modo economicamente eficiente, dada a tecnologia disponivel.

De um modo genérico, os modelos operacionais propostos podem ser representados por:

1) Modelo I:

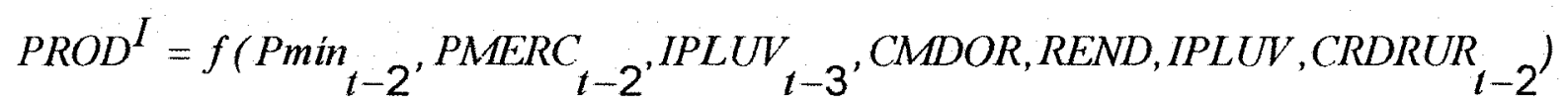

onde,

$P R O D^{I}=$ produção de mandioca dos produtores do Grupo l;

$P_{\text {min }}$-2 = preço minimo de mandioca defasado em 2 anos;

$P M E R C_{t-2}=$ preço de mercado de mandioca defasado em 2 anos;

IPLUV $_{t-3}=$ índice pluviométrico defasado em 3 anos, como uma "proxy" da disponibilidade de manivas-sementes;

$C M D O R=$ custo da mão-de-obra rural;

$R E N D=$ rendimento físico por unidade de área; 
IPLUV = indice pluviométrico; e

CRDRUR $_{t-2}=$ volume de crédito rural aplicado na cultura da mandioca, defasado em 2 anos.

2) Modelo II:

PROD ${ }^{I I}=f\left(\right.$ Pmin $_{t-2}$, PMERC $_{t-2}$, IPPC, CMDOR, REND, PFNORD $\left.t_{t-2}, C R D R U R_{t-2}\right)$

onde;

$P R O D^{I I}=$ produção de mandioca dos produtores do Grupo II;

$I P P C=$ índice de preço dos produtos concorrentes; $\mathrm{e}$

PFNORD $_{t-2}=$ preço da farinha de mandioca na Região Nordeste.

As demais variáveis possuem o mesmo significado do modelo $\mathrm{I}$.

\subsubsection{Especificação do modelo}

$\mathrm{Na}$ especificação do modelo foi contemplada a idéia de que os agricultores estimulados pelas politicas públicas, passam a organizar suas atividades produtivas visando no longo prazo completar a resposta apresentada de imediato, ou seja, o ajustamento não ocorre instantaneamente. Modelos empíricos dessa natureza foram desenvolvidos por Nerlove para a estimação da oferta de produtos agrícolas e, pertencem à categoria dos modelos de defasagens distribuídas. Isto é, quando a variável dependente aparece como função de variáveis independentes defasadas no tempo (PASTORE, 1973). A variação de área cultivada entre dois periodos 
especificos reflete uma proporção entre o que foi cultivado no período anterior e o que se pretende cultivar no longo prazo (17).

O modelo econométrico usado para estimar as relações pressupostas anteriormente é da forma:

$$
Y_{t}^{*}=\alpha+\sum_{i=1}^{k} \beta_{i} X_{i t}+u_{t}
$$

onde;

$Y_{t}^{*}=$ variável dependente no longo prazo, no tempo $t$.

$\alpha \in \beta_{i}=(k+1)$ parâmetros a serem estimados, $i=1,2, \ldots k$;

$X_{i t}=\mathrm{i}$-ésima variável independente no tempo $t$; e

$u_{t}=$ erros observados no tempo $t$.

Considerando-se o modelo de Nerlove, o caminho percorrido durante o ajustamento é:

$Y_{t}-Y_{t-1}=\omega\left(Y_{t}^{*}-Y_{t-1}\right)+w_{t} \quad$ para $0<\omega<$

onde:

$\omega=$ coeficiente ou elasticidade de ajustamento; e

$Y_{t}=$ variável dependente no tempo $t$;

$w_{t}=$ erro aleatório

Substituindo (01) em (02), obtêm-se:

$Y_{t}=\gamma_{o}+\sum_{i=1}^{k} \gamma_{i} X_{i t}+\delta_{1} Y_{t-1}+\varepsilon_{t}$

onde:

$\gamma_{o}=$ parâmetro a ser estimado, equivalente $a \omega \alpha$;

$\left({ }^{17}\right)$ Ver sobre 0 assunto NERLOVE (1958). 
$\gamma_{i}=$ parâmetros a serem estimados, sendo $\gamma_{i}=\omega \beta_{i}$;

$\delta_{1}=$ parâmetro a ser estimado, equivalente a $(1-\omega)$; e

$\varepsilon_{t}=$ erro aleatório, equivalente a $\omega u_{t}+w_{t}$

Na tentativa de identificar os efeitos das políticas públicas no desempenho da cultura da mandioca, serão estimadas equações para cada um dos Estados da Federação (unidades cross-section) que ocupam posição destacada na produção. Ou seja, serão escolhidos os Estados com maior participação relativa $(18)$ e/ou melhor nível tecnológico. Para o Grupo I sugere-se os Estados do Pará, Maranhão e Bahia. Já para o Grupo Il os Estados de Minas Gerais, São Paulo, Paraná e Rio Grande do Sul.

Atendidas as pressuposiçōes $(19)$ usuais de um modelo estatistico de regressão linear múltipla, as equações referentes aos modelos I e II, para cada Estado, podem ser estimadas pelo método dos mínimos quadrados ordinários Entretanto $(20)$, os erros destas diferentes equações em um dado tempo são provavelmente reflexo de um mesmo fator comum imensurável ou omitido, por isso, podem estar correlacionados. Nestas condições, o estimador de minimos quadrados ordinários pode não ser 0 adequado.

Para citar um exemplo deste tipo de problema, JUDGE et alii (1988) consideram que num estudo de oferta agrícola, o efeito das condições climáticas em um dado ano é provavelmente um efeito que tem relevância sobre os erros dos diferentes produtos. Esta correlação entre os erros de diferentes equações em um dado momento, é conhecida como correlação contemporânea. Note-se, que essa

(18) Na Tabela A1 apresentam-se os Estados da Federação e sua respectiva participação relativa na produção de mandioca no ano de 1994.

$\left.{ }^{19}\right)$ As pressuposições básicas com relação ao erro são: (erro) $u_{t} \sim N\left(0, \sigma^{2}\right) \mathrm{e}$ nãocorrelacionado com o erro de outra observação.

$\left({ }^{20}\right)$ A discussão a seguir foi baseada em JUDGE et alii (1988) e PINDYCK \& RUBINFELD (1991). 
situação é diferente do que geralemente chama-se de autocorrelação nos residuos. Nesse caso, a correlação existente ao longo do tempo refere-se apenas a uma equação.

Para se testar a existência de correlação conteporânea, será empregado o teste estatistico sugerido por Breusch and Pagan apresentado em JUDGE et alii (1988, p.456). Caso a correlação contemporânea seja diferente de zero (0), alternativamente, os parâmetros serão estimados usando-se o SUR (seemingly unrelated regression).

Se não for identificada correlação contemporânea e considerando-se a suposição de homogeneidade nos grupos de produtores (ver Tabela 4), o que permite aceitar que os parâmetros estimados (exceto o intercepto) em cada unidade cross-section permanece constante durante todo o tempo, pode-se estimar os parâmetros usando-se um processo que combine dados em cross-section (coletados em um mesmo periodo) com dados de séries temporais. Dessa maneira, obtêm-se parâmetros estimados mais eficientes. Esse processo é chamado de pooling (PINDYCK \& RUBINFELD, 1991, p.223).

Dentro desse processo, pelo menos dois modelos devem ser considerados: 0 modelo de componentes do erro e o modelo de covariancia. Resta saber qual modelo escolher. JUDGE et alii (1988) sugerem que quando a série temporal for muito grande e a quantidade de unidade cross-section for pequena, os dois modelos proporcionam estimadores semelhantes. Neste caso, a escolha de qual modelo utilizar recai sobre as facilidades computacionais.

No presente estudo, sem entrar no mérito da polêmica discussão sobre tamanho de amostras, será escolhido o modelo de covariância. A escolha desse modelo, além de estar respaldada pelo tamanho da série (1972 a 1994), também parece ser o mais apropriado para atender aos nossos objetivos. Ou seja, irá fornecer indicativos a respeito do comportamento dos produtores de mandioca frente às 
políticas públicas e, complementarmente captar as diferenças especificas entre cada Estado. Diante disso, segue-se uma apresentação do modelo de covariância.

Inicialmente, é necessário ressaltar que para se obter estimativas estaduais usando esse procedimento, novamente, é feita a suposição de que o relacionamento entre as váriaveis independentes e a variável dependente é o mesmo para todos os Estados (parâmetros constantes). Todavia, supōe-se que o comportamento dos Estados se diferencia no nivel médio de resposta às politicas (variáveis independentes), isto é, que as estimativas dos Estados diferenciam-se somente nos coeficientes lineares estimados (interceptos) (ASSIS, 1978). Esse comportamento será captado por meio de variáveis binárias (dummy variables) incorporada ao modelo.

Partindo-se da equação (03), incorporando-se as variáveis binárias e fazendose pequenas adaptações, o modelo de covariância pode ser escrito da seguinte forma:

$$
Y_{t}=\sum_{h=1}^{N} \theta_{h} D_{h t}+\sum_{i=1}^{k} \gamma_{i} X_{i t}+\delta_{1} Y_{t-1}+\varepsilon_{t}
$$

onde:

$D_{h t}=$ variáveis binárias, que assumem valores iguais a 0 ou 1 . Considerandose $j=1,2, \ldots, N$ número de unidades cross-section, especificamente, $D_{h t}=$ se $h=j ;$ e $D_{h t}=0$ se $h \neq j$.

Ressalta-se que na equação (04), além de outras modificações, foi suprimida a constante $(\alpha)$ no modelo representado na equação (03). Se fosse incluida, tambèm a constante, além das variáveis binárias para cada unidade cross-section, o resultado seria de multicolinearidade perfeita. 
Na aplicação empírica do modelo de covariânica, freqüentemente são feitas as seguintes questões: Existem evidências que sugerem que as diferentes unidades cross-section possuem interceptos diferentes? Poderia ser adequado assumir interceptos idênticos para todos as unidades, e assim não haveria a necessidade de se incluir variáveis binárias? Estas questões podem ser resumidas e formuladas em termos do següinte teste de hipótese:

$$
\begin{aligned}
& H_{o}=\theta_{1}=\theta_{2}=\ldots \theta_{N} \\
& H_{A}=\operatorname{os~} \theta_{h} \text { não são todos iguais. }
\end{aligned}
$$

Para testar esta hipótese, usa-se um teste estatístico apropriado, onde se compara os modelos em termos de um conjunto de restrições lineares. Na verdade, compara-se um modelo estimado sem as variáveis binárias com um modelo de covariância. Uma maneira de se efetuar essa comparação, è calculandos-se um F estatístico expresso em função da soma dos quadrados dos residuos dos dois modelos (restrito e não restrito). É fácil perceber que o modelo de covariância é menos restrito do que 0 modelo sem as variáveis binárias. Neste contexto, o $F$ estatístico é dado por:

$$
F_{N-1, G L_{2}}=\frac{\left(S Q R_{1}-S Q R_{2}\right) /(N-1)}{S Q R_{2} / G L_{2}}
$$

onde:

$S Q R_{1}=$ soma dos quadrados do modelo restrito;

$S Q R_{2}=$ soma dos quadrados do modelo não restrito;

$(N-1)=$ número de restriçōes lineares; e

$G L_{2}=$ graus de liberdade do modelo não restrito. 
Poder-se-ia, também, testar a hipótese de existência de efeito característico para cada ano. Isso seria possivel com a incorporação de mais variáves binárias para cada ano específico da série. Entretanto, dado ao tamanho da série, certamente, esse procedimento reduziria os graus de liberdade e, por isso não será considerado neste estudo. Ademais, as informações advindas de tal procedimento não interessam nesta oportunidade.

\subsubsection{Definição das Variáveis}

1) MODELO :

a) Produção de mandioca - PROD: produção anual de mandioca nos respectivos Estados, expressa em toneladas, no periodo de 1972 a 1994. As demais variáveis também são consideradas para o mesmo periodo. A utilização da produção como variável para captar a sensibilidade da curva de oferta aos estímulos do mercado, pode não ser a mais recomendada, pois, a produção efetiva não está inteiramente sob o controle do agricultor. A interferência de fatores climáticos, por exemplo, pode alterar a produção, fazendo com que esta seja muito diferente da produção planejada em função dos estimulos do mercado. A área cultivada parece ser a melhor variável para representar o comportamento do agricultor em função das mudanças do mercado (ALMEIDA, 1994). Neste estudo, utilizar-se-á a produção, em virtude da dificuldade de se encontrar informações referentes a área plantada para o periodo aqui considerado. Diante desta situação, foram incluidas nos modelos, algumas variáves explanatórias com o objetivo de compensar o problema. Dentro deste contexto, os modelos empregados nesta pesquisa não devem ser entendidos como estimativas tradicionais das relações de oferta de mandioca, nem também como uma função de produção, pois não incorpora todos as variáveis que caracteriza 
a mesma. Em última análise, embora considere pressupostos básicos de ambas funções, os modelos tentam refletir o comportamento dos produtores de mandioca frente às políticas públicas.

b) Preço mínimo da mandioca - $\operatorname{Pmin}_{t-2}$ preço mínimo médio anual da tonelada de mandioca, defasado em 2 anos, nos respectivos Estados (Pará, Maranhão e Bahia), em unidades monetárias $(R \$)$. Essa variável tenta captar a resposta dos produtores aos estímulos da política de preço mínimo. Espera-se para o parâmetro estimado sinal positivo.

c) Preço de mercado da mandioca - $P M E R C_{t-2}$ : preço médio anual recebido pelos produtores, por uma tonelada de mandioca, defasado em 2 anos, nos respectivos Estados, em unidades monetárias (R\$). Pressupõe-se que o coeficiente da variável apresente sinal positivo.

d) Índice pluviométrico defasado - IPLUV $t-3$ : quantidade pluviométrica média anual defasada em 3 anos $(21)$, medida em $\mathrm{mm}$ de chuva, nas microrregióes onde concentra-se a produção de mandioca nos respectivos Estados. Esta variável, na medida em que tenta captar a disponibilidade de manivas-sementes ("proxy"), também reflete, em algum grau, um componente do custo de produção. O coeficiente desta variável deverá apresentar sinal positivo.

e) Custo da mão-de-obra rural - CMDOR: preço real médio do valor da mãoobra-rural (diária), em unidades monetárias (R\$), nos respectivos Estados. Como a cultura da mandioca demanda uma quantidade de mão-de-obra considerável, essa variável pode ser utilizada como uma "proxy" do custo de produção da cultura. 0 parâmetro estimado deverá apresentar sinal negativo.

(21) Para definição do periodo de defagem usou-se o seguinte raciocínio: em condições climáticas adversas os produtores são obrigados a utilizar todo a parte aérea da mandioca no arraçoamento animal. Esse comportamento irá ter reflexos imediatos no próximo plantio e conseqüentemente na produção dos 3 (três) anos subseqüente. 
f) Rendimento físico por unidade de área - REND : quantidade produzida de mandioca por hectare, expresso em $\mathrm{Kg} / \mathrm{ha}$, nos respectivos Estados. Pode-se considerar esta variável como uma indicadora da resposta aos investimentos em tecnologia. Espera-se para o parâmetro estimado sinal positivo.

g) Índice pluviométrico - IPLUV: comtempla a mesma descrição apresentada no item d, sem a defasagem. Além do objetivo de captar os condicionantes ambientais favoraráveis à implantação e condução da cultura, em conjunto com a variável anterior, ela funciona no modelo como uma espécie de compensação ao uso da produção ao invés da área plantada como variável dependente. $O$ coeficiente desta variável deverá apresentar sinal positivo.

h) Crédito rural - $C R D R U R_{t-2}$ volume anual de recursos aplicados no crédito rural para o custeio da cultura da mandioca, nos respectivos Estados, medido em reais $(R \$)$. A exemplo das demais variáveis indicadoras de politica, espera-se sinal positivo para o coeficiente desta variável.

2) Modelo II:

a) Índice de preço dos produtos concorrentes - IPP : indice de preço de Fisher, construído com base nos produtos trigo, milho e soja. Com essa variável pretende-se quantificar os efeitos das políticas de incentivo diferenciado. $O$ parâmetro estimado desta variável deverá apresentar sinal negativo.

b) Preço da farinha de mandioca na Região Nordeste - PFNORD $D_{-2}$ : preço médio anual, da saca de $50 \mathrm{~kg}$, da farinha de mandioca "comum" comercializada no mercado de Salvador (Bahia), em unidades monetárias $(R \$)$. O coeficiente desta variável deverá apresentar sinal positivo. 
Conforme mencionado anteriormente, as demais variáveis que compõem o modelo II, possui o mesmo significado do modelo I.

Quanto à forma funcional de estimação dos modelos, será dada preferência à forma linear nos logaritmos das variáveis, por fornecer as elasticidades diretamente dos resultados da regressão estimada. Evidente que outras formas funcionais serão testadas, sendo contudo, consideradas apenas se apresentarem um melhor ajustamento.

Os modelos de regressão ajustados neste estudo serão avaliados por meio dos testes estatísticos tradicionalmente utilizados. Ou seja, o valor do $\mathbf{t}$ de Student, será utilizado para determinar a significância estatística dos coeficientes das regressões. $O$ teste de $F$ de Snedecor, será utilizado para verificar a significância estatistica das regressões obtidas. O grau de ajustamento das equações estimadas será medido pelo coeficiente de determinação múltipla $\mathrm{R}^{2}$.

Considerando-se que se esta trabalhando com informações que envolvem dados de séries temporais será razoável verificar se há autocorrelação nos resíduos das regressões. Para verificar a existência de autocorrelação nos resíduos será usado a teste estatístico $h$ proposto por Durbin(22).

Outro aspecto a ser considerado, refere-se a presença de multicolinearidade entre as variáveis explanatórias. Como indicativo da presença de multicolinearidade, será tomado o coeficiente de correlação simples $(23)$ entre as referidas variáveis.

${ }^{22}$ ) O teste de Durbin-Watson não é apropriado para detectar a presença de autocorrelação nos resíduos em modelos com valores defasados da variável endógena (modelo nerloviano por exemplo), sendo recomendado o uso de outros testes (HOFFMANN 1987 p.272).

${ }^{23}$ ) HOFFMANN (op. cit. p.159) ressalta que "é importante compreender que no caso de uma regressão com mais de duas variáveis independentes pode existir multicolinearidade perfeita, mesmo que nenhum dos coeficientes de determinação simples seja igual a um". Convém também salientar, que o coeficiente correlação simples apresenta o inconveniente de não identificar a presença de multicolinearidade entre mais de duas variáveis. 


\subsection{OUtros Procedimentos Metodológicos Utilizados no Estudo}

\subsubsection{Redundância}

A cultura da mandioca, dada às características históricas do seu desempenho, convive com uma condição desfavorável em relação à política de crédito vis-à-vis outros produtos. Em outras palavras, o baixo retorno econômico experimentado pela cultura pode induzir a uma incipiente aplicação de crédito. Complementando, o fraco desempenho da cultura da mandioca pode ter enfatizado a caracteristica de fungibilidade associada ao dinheiro recebido como crédito rural. No caso dessa cultura, isso pode ter levado com mais intensidade aos poucos produtores que tiveram acesso ao crédito, a orientarem os seus recursos para atividades de maior retorno e, conseqüentemente, não ampliando os investindo na cultura a que se destinavam.

Contudo, há argumentos que apontam em outra direção. Conforme mencinado na seção 4.1.2, o processo de "desvio" do crédito será função direta do nivel de acesso do tomador de crédito às fontes alternativas de recursos e das possibilidades de investimentos não-agricolas. De fato, as características dos produtores de mandioca não condizem com esse perfil.

Diante desses argumentos contraditórios a respeito do comportamento dos produtores de mandioca frente ao crédito e, da dificuldade de se aplicar testes empiricos para a avaliar esse comportamento, optou-se por uma avaliação onde foram adotados procedimentos semelhantes aos utilizados por MESQUITA (1994) na análise de alguns indicadores operacionais dos instrumentos de politica econômica. Ou seja, analisaram-se os seguintes aspectos: abrangência, volume, posição relativa do crédito rural para mandioca frente ao crédito rural total e a respectiva participação na área total colhida e no valor da produção das culturas selecionadas. 
Em adição, com o objetivo de demonstrar o comportamento da distribuição do crédito rural para custeio entre culturas, foram calculados índices de concentração de crédito, pois, a existência de concentração pode ser adotada como um indicativo de racionamento do crédito e, conseqüentemente da orientação dos recursos para os produtos de maior rentabilidade. Para isso foi utilizada a medida de concentração elou desigualdade chamada de redundância $(24)$.

O indice de redundância da distribuição do crédito de custeio agricola entre culturas, foi calculado em relação a área colhida e ao valor da produção para os anos 1980, 1985 e 1990. Já indice de redundância da distribuição do crédito de custeio entre Estados, foi calculado em relação a área colhida e a produção, para os anos de $1970,1975,1980,1985$ e 1990.

A redundância total $(R)$ pode ser apresentada como:

$$
R=\sum_{i=1}^{n} y_{i} \ln \frac{y_{i}}{h_{i}}
$$

onde:

$R=$ redundância da distribuição do crédito rural;

$(i . . n)=$ número de culturas ou Estados selecionadas;

$y_{i}=$ participação relativa da(o) i-ésima(o) cultura(Estado) no crédito para

custeio agricola;

$h_{i}=$ participação relativa da i-ésima cultura no total da área colhida ou no valor da produção das culturas selecionadas. Ou participação relativa do iésimo Estado na área total ou na produção total de mandioca no Brasil; e $0 \leq R \leq \ln [1 / \min (\pi)]$, sendo que $\min (\pi)$ representa o menor dos $h_{i}$ SHIROTA (1988). 
A redundância total será igual a 0 (zero) - valor mínimo da redundância -, se para todas(os) as(os) culturas (ou Estados) selecionadas(os) a participação relativa no crédito rural for exatamente igual à participação no total da área colhida, no valor da produção agropecuária ou na produção de mandioca. Por outro lado, a redundância será máxima quando todo o crédito for canalizado para a(o) cultura (ou Estado) que represente a menor participação relativa na área colhida, no valor da produção ou na produção.

A redundância depende da distribuição do crédito em relação às distribuições das variáveis consideradas (área colhida, valor da produção e produção). Ou seja, de acordo com HOFFMANN \& KAGEYAMA (1987), a redundância permite medir a concentração (ou desigualdade) da distribuição do crédito em relação às variáveis.

A interpretação dada à redundância neste trabalho foi a mesma considerada por BARNES MOLINAR (1984), HOFFMANN \& KAGEYAMA (1887) e SHIROTA (1988). Isto é, a redundância não medirá simplesmente a concentração do crédito, mas sim a discrepância entre a distribuição do crédito e a distribuição da área colhida ou a do valor da produção. Nesse sentido, quanto maior for a discrepância entre as distribuições das variáveis consideradas, maior será o valor da redundância total.

No presente trabalho os cálculos para o índice de redundância foi feito com logaritmos naturais $(25)$, logo o referido índice está medido em nits (natural logarithms).

\subsubsection{O modelo "shift-share"}

Os procedimentos metodológicos complementares utilizados para a análise, tanto da politica de mudança tecnológica quanto da política de incentivo diferenciado

(25) Quando utilizamos logaritmos de base 2 dizemos que os indices são medidos em bits (HOFFMANN, 1991). 
aos produtos concorrentes da cultura da mandioca na produção, foram os do modelo "shift-share" (também denominado diferencial estrutural) utilizado inicialmente na agricultura brasileira por PATRICK (1975), e modificado por IGREJA et alii (1982). Esta metodologia vem sendo utilizada por diversos autores para estudar o desempenho de algumas atividades agropecuárias no Brasil; por exemplo, ZOCKUN (1978), CAMARGO (1983), IGREJA (1987), GASQUES \& VILLA VERDE (1990) e CAMPOS (1994).

O período analisado foi de 1970 a 1985 , subdividido nos subperiodos $(1970 / 75,1975 / 80,1980 / 85$ e 1975/85) correspondentes aos censos agropecuários, que foram as fontes dos dados, fazendo-se uma análise com enfoque nacional. As fontes de crescimento considerados foram analisadas considerando-se 8 (oito) estratos de área total $(26)$.

Um reflexo dos investimentos em tecnologia agrícola é o aumento da produção e difusão de novos conhecimentos que, finalmente, irão contribuir para o crescimento do produto agrícola, via aumento da produtividade dos fatores de produção.

De acordo com SILVA (1984), o ideal para se mensurar os efeitos do progresso tecnológico no desempenho de culturas, è se trabalhar com ganhos de produtividade total. Entretanto, a inexistência de informações sobre o uso dos diferentes fatores de produção torna dificil tal procedimento, recorrendo-se geralmente à produtividade da terra. Assim sendo, para avaliar o impacto da política de mudança tecnológica no desempenho da cultura da mandioca, foi analisado a contribuição do rendimento físico por unidade de área para a produção, como uma "proxy" do processo de mudança tecnológica.

${ }^{(26)}$ Os estratos são: menos de 2 ha; de 2 a 5 ha; 5 a 10 ha; 10 a $20 ; 20$ a 50 ha; 50 a 100 ha; 100 a 500 ha e mais de 500 ha. 
Convém ressaltar que a política de mudança tecnológica não é o único fator responsável pelo aumento do rendimento físico por área das culturas. Segundo VERA FILHO \& TOLLINI (1979 p. 110), "a variável rendimento não está necessariamente associada a progresso tecnológico". Os autores consideram que "em um dado periodo de tempo, agricultores que obtêm maior rendimento por hectare podem estar empregando processos produtivos menos eficientes que os adotados por agricultores cuja produção por hectare é menor". Esses autores afirmam, que "ao longo do tempo, no entanto, a variável rendimento constitui indicador parcial de progresso tecnológico, posto que inovações tecnológicas neutras e poupadoras de terra implicam em acréscimos nos rendimentos; constitui indicador parcial por não refletir a ocorrência de mudança tecnológica estritamente poupadora de mão-deobra"(27). Muitos autores $(28)$ consideram o rendimento físico por hectare, no caso do Brasil, como um elemento decisivo para explicar os ganhos alcançados até aqui pelo setor agricola. O efeito-rendimento pode captar os reflexos de mudanças tecnológicas visando poupar o fator terra (YOKOYAMA, 1988). Diante disto, no presente trabalho esta foi a orientação dada ao cálculo do efeito-rendimento. Isto é, ele quantifica a contribuição do rendimento físico por área na variação da produção da mandioca.

Alternativamente, o esforço de geração de tecnologia agricola para a cultura da mandioca foi, também, avaliado em função do total dos investimentos em pesquisa, representado no volume de recursos destinado à referida cultura em comparação com outros produtos. Nesse caso, o universo de estudo foram os recursos investidos pela EMBRAPA.

(27) Segundo Solow, citado por VERA FILHO \& TOLLINI (1979), o progresso tecnológico que implica no aumento proporcionalmente igual da produtividade de todos os fatores de produção é classificado como neutro, ou seja, não há mudanças nas taxas de substituição entre fatores.

${ }^{28}$ ) Por exemplo MENDONÇA DE BARROS (1983, p.273), IGREJA et alii $(1988, p .6)$, GASQUES \& VILLA VERDE (1990, p.192) e YOKOYAMA $(1993, p .52)$. 
Para avaliar os impactos das politicas de incentivo diferenciado aos produtos concorrentes da mandioca na produção, foram enfatizadas as variaçóes na área cultivada total, sendo esta decomposta nos respectivos efeitos escala e substituição.

A hipótese subjacente foi que os produtos que foram alvo das politicas de incentivo diferenciado apresentaram um maior lucro por unidade de área e por conseguinte ocuparam áreas das lavouras que não foram beneficiadas com as referidas politicas.

Para melhor compreensão, apresenta-se, então, o modelo e a respectiva formulação matemática $(29)$ da técnica referente ao cálculo dos efeitos área (decomposto nos efeitos escala e substituição), rendimento e localização geográfica. Esses efeitos podem ser definidos como:

(i) Efeito área: reflete parte das mudanças na produção como conseqüência de variações na área cultivada, supondo que o rendimento, e a localização geográfica permaneçam constantes.

(ii) Efeito rendimento: indica uma intensificação da agricultura, uma vez que representa, em termos parciais, o resultado da aplicação de novas técnicas e/ou insumos na produção, mantidas as outras fontes de crescimento inalteradas.

(iii) Efeito localização geográfica: mostra mudanças na produção decorrentes de alterações na localização das lavouras, entre unidades geográficas (no caso entre estratos de área total), que pode ser resultado de uma alocação mais eficiente dos recursos escassos, mantidas constantes as demais fontes de crescimento. 


\section{a) Variáveis consideradas}

O índice $h$ indica a lavoura, variando de acordo com o subperíodo estudado de 1 a 18. $O$ indice $\mathrm{i}$ indica o estrato de área total, variando de 1 a 8 . As culturas nos respectivos periodos foram: 1970-75 e 1975-80 - banana, cacau, café, laranja, uva, algodão arbóreo, amendoim, arroz, batata, cana-de-açúcar, feijão, mandioca, milho, soja, trigo, pastagem natural e pastagem plantada. 1980-85 e 1975-85 - banana, cacau, café, laranja, uva, algodão arbóreo, algodão herbáceo, arroz, batata, cana-deaçúcar, feijão, mandioca, milho, soja, trigo, tomate, pastagem natural e pastagem plantada.

Os periodos inicial e final são indicados pelos indices o e $t$, respectivamente. $Q_{h}=$ produção da h-ésima lavoura no Brasil, nos anos $1970,1975,1980$ e 1985, em tonelada. A banana e a laranja em mil cachos e mil frutos respectivamente.

$A T$ =área total em hectare, cultivada com as lavouras nos anos considerados (dimensão do sistema no Brasil ou no respectivo estrato de área total). $A_{h i}=$ área total em hectare, cultivada com a h-ésima lavoura, no i-ésimo estrato de área total.

$A_{h}=$ área total em hectare da h-ésima lavoura cultivada no Brasil.

$R_{h i}=$ rendimento em $\mathrm{Kg} / \mathrm{ha}^{(30)}$, da h-ésima lavoura, no i-ésimo estrato de área total.

$\alpha_{i h}=\frac{A_{h i}}{A_{h}}=$ proporção do i-ésimo estrato de área, na área cultivada com a $\mathrm{h}$ ésima lavoura no Brasil. 
$\beta=\frac{A T_{t}}{A T_{o}}=$ coeficiente que mede a modificação na área total cultivada das lavouras (dimensão do sistema), no Brasil, entre os períodos inicial o e final $t$, respectivamente.

\section{b) Análise por cultura}

É fácil perceber que a análise individual das culturas foi feita considerando-se - Brasil como universo, ou seja, como dimensão do sistema. Nessa análise pode-se distinguir os efeitos área, rendimento e localização geográfica considerando-se os estratos de área

No período inicial o a produção da h-ésima lavoura no Brasil é dada por:

$$
Q_{\text {ho }}=\sum_{i=1}^{m} A_{\text {hio hio }} R_{i=1}=\sum_{i \text { iho }}^{m} A_{\text {ho hio }} R_{\text {his }}
$$

No periodo final $\mathbf{t}$ a produção da h-ésima lavoura no Brasil é dada por:

$$
Q_{h t}=\sum_{i=1}^{m} A_{\text {hit }} R_{\text {hit }}=\sum_{i=1}^{m} \alpha_{\text {iht }} A_{h t} R_{\text {hit }}
$$

Se no periodo t, apenas a área da h-ésima lavoura se alterar, a produção será dada por:

$$
Q_{h t}^{A}=\sum_{i=1}^{m} \alpha_{i h o} A_{h t} R_{h i o}
$$

Se a localização geográfica permanecer constante, mas a área cultivada e os rendimentos variarem, em cada estrato de área, a produção final será:

$$
Q_{h t}^{A, R}=\sum_{i=1}^{m} \alpha_{i h o} A_{h t} R_{h i t}
$$

Finalmente, se forem alteradas todas as fontes de crescimento consideradas neste estudo, ou seja, área, rendimento e localização geográfica, o produto final será: 


$$
Q_{h t}^{A, R, \alpha}=\sum_{i=1}^{m} \alpha_{i h t} A_{h t} R_{h i t}=Q_{h t}
$$

A mudança total na produção entre o periodo inicial $(0)$ e o final (t) pode ser determinada como:

$$
Q_{h t}-Q_{h o}=\sum_{i=1}^{m} \alpha_{i h t} A_{h t} R_{h i t}-\sum_{i=1}^{m} \alpha_{\text {iho }} A_{\text {ho }} R_{\text {hio }}
$$

ou

$$
Q_{h t}-Q_{h o}=\left(Q_{h t}^{A}-Q_{h o}\right)+\left(Q_{h t}^{A, R}-Q_{h o}^{A}\right)+\left(Q_{h t}-Q_{h t}^{A, R}\right)
$$

onde os efeitos isolados em (12), podem ser expressos como:

$Q_{h t}-Q_{h o}=$ variação total na produção da h-ésima lavoura entre o periodo o e $\mathbf{t}$

$\left(Q_{h t}^{A}-Q_{h o}\right)=$ efeito área (EA);

$\left(Q_{h t}^{A, R}-Q_{h o}^{A}\right)=$ efeito rendimento (ER); e

$\left(Q_{h t}-Q_{h t}^{A, R}\right)=$ efeito localização geográfica (ELG)

O ELG pode ser expresso como:

$$
\begin{aligned}
\text { ELG } & =\sum_{i=1}^{m} \alpha_{i h t} A_{h t} R_{h i t}-\sum_{i=1}^{m} \alpha_{i h o} A_{h t} R_{h i o} \\
& =A_{h t}\left(\sum_{i=1}^{m} \alpha_{i h t} R_{h i t}-\sum_{i=1}^{m} \alpha_{i h o} R_{h i t}\right)
\end{aligned}
$$

É fácil verificar que a expressão entre parênteses é a diferença entre duas médias ponderadas dos $R_{h i t}$, mudando o fator de ponderação. Quanto maior os 
pesos dos $R_{\text {hit }}$ mais altos, maior será a média ponderada. Logo, o ELG será positivo se aumentar a participação do estrato de área onde o rendimento no periodo t é mais alto.

c) Apresentação dos resultados na forma de taxas anuais de crescimento

Para facilitar a comparação entre periodos de tempo e/ou estratos de área, os efeitos serão expressos individualmente como uma porcentagem da mudança total na produção. Vale ressaltar, que por exemplo, um efeito rendimento de $25 \%$ indica que $1 / 4$ do aumento de produção é explicado pelo maior rendimento, mas não significa que os rendimentos médios tenham aumentado em $25 \%$.

Tomando como base YOKOYAMA (1988), a apresentação dos resultados na forma de taxas de crescimento, seguirá a metodologia proposta por IGREJA (1987).

Multiplicando-se ambos os lados da expressão (12) por:

$$
1 /\left(Q_{h t}-Q_{h o}\right)
$$

tem-se:

$$
1 \equiv \frac{\left(Q_{h t}^{A}-Q_{h o}\right)}{\left(Q_{h t}-Q_{h o}\right)}+\frac{\left(Q_{h t}^{A, R}-Q_{h t}^{A}\right)}{\left(Q_{h t}-Q_{h o}\right)}+\frac{\left(Q_{h t}-Q_{h t}^{A, R}\right)}{\left(Q_{h t}-Q_{h o}\right)}
$$

Multiplicando-se ambos os lados da identidade (13) por:

$$
r=\left(\sqrt[t]{Q_{h t} / Q_{h o}}-1\right) 100
$$

onde: $r=$ taxa anual média de variação na produção da h-ésima lavoura, em porcentagem ao ano. Obtendo-se assim: 


$$
r=\frac{\left(Q_{h t}^{A}-Q_{h o}\right)}{\left(Q_{h t}-Q_{h o}\right)} r+\frac{\left(Q_{h t}^{A, R}-Q_{h t}^{A}\right)}{\left(Q_{h t}-Q_{h o}\right)} r+\frac{\left(Q_{h t}-Q_{h t}^{A, R}\right)}{\left(Q_{h t}-Q_{h o}\right)} r
$$

onde para a h-ésima lavoura tem-se:

$$
\begin{aligned}
& \frac{\left(Q_{h t}^{A}-Q_{h o}\right)}{\left(Q_{h t}-Q_{h o}\right)} r=\text { efeito área (EA), expresso em \% de crescimento ao ano. } \\
& \frac{\left(Q_{h t}^{A, R}-Q_{h t}^{A}\right)}{\left(Q_{h t}-Q_{h o}\right)} r=\text { efeito rendimento (ER), expresso em \% ao ano. } \\
& \frac{\left(Q_{h t}-Q_{h t}^{A, R}\right)}{\left(Q_{h t}-Q_{h o}\right)} r=\text { efeito localização geográfica (ELG), expresso em \% ao ano. }
\end{aligned}
$$

d) Decomposição do efeito área

Segundo ZOCKUN (1978), o efeito escala seria dado pela variação na área do produto considerado, apenas pela alteração do tamanho do sistema, mantendo inalterada sua participação dentro do sistema. $O$ efeito substituição mostra a variação da participação dentro do sistema: se sua participação caiu, o efeito substituição será negativo, indicando que entre os períodos analisados o produto considerado foi substituído por outro produto do sistema. Se a participação do produto elevar-se no segundo periodo relativamente à que ele tinha no primeiro, o efeito substituição será positivo, indicando que o produto considerado substituiu outros dentro do sistema.

A variação na área ocupada por uma determinada lavoura $\mathbf{h}$, em cada sistema de produção, é expressa por.

$$
\left(A_{h t}-A_{h o}\right)
$$


Sendo, $\beta$ o coeficiente que mede a variação do tamanho do conjunto das lavouras consideradas no estudo, a expressão (15) pode ser decomposta, em termos de grandeza de área, em dois efeitos:

$$
\begin{aligned}
& \left(\beta A_{h o}-A_{h o}\right)=\text { Efeito Escala (EE) } \\
& \left(A_{h t}-\beta A_{h o}\right)=\text { EfeitoSubstituição (ES) }
\end{aligned}
$$

Dentro do sistema em estudo somente se verifica o efeito escala, pois o somatório dos efeitos substituição é igual a zero. Ou seja:

$$
\sum_{h=1}^{k}\left(A_{h t}-\beta A_{h o}\right)=0
$$

e,

$$
\left(A_{h t}-A_{h o}\right)=\left(\beta A_{h o}-A_{h o}\right)+\left(A_{h t}-\beta A_{h o}\right)
$$

Para a apresentação dos efeitos escala e substituição na forma de taxas anuais de crescimento, usa-se o mesmo procedimento matemático apresentado na expressão (12). Assim, multiplicando-se ambos os lados da expressão (19) por

$$
1 /\left(A_{h t}-A_{h o}\right)
$$

obtém-se:

$$
1 \equiv \frac{\left(\beta A_{h o}-A_{h o}\right)}{\left(A_{h t}-A_{h o}\right)}+\frac{\left(A_{h t}-\beta A_{h o}\right)}{\left(A_{h t}-A_{h o}\right)}
$$

Multiplicando-se ambos os lados da identidade (20) pelo efeito área (EA), definido anteriormente, obtém-se:

$$
\frac{\left(\beta A_{h o}-A_{h o}\right)}{\left(A_{h t}-A_{h o}\right)} E A=\text { Efeito Escala, expresso em \% ao ano; }
$$


$\frac{\left(A_{h t}-\beta A_{h o}\right)}{\left(A_{h t}-A_{h o}\right)} E A=$ Efeito Substituição, expresso em \% ao ano.

Para se saber qual a parcela das áreas cedidas pelas lavouras que tiveram efeito substituição negativo, foram incorporadas pelas lavouras que tiveram efeito substituição positivo, será pressuposto que aquelas que cederam área fizeram proporcionalmente para todas as lavouras que tiveram o efeito substituição positivo. Assim sendo, tem-se:

$$
c_{h}=\frac{E S_{h} N}{\sum E S N}
$$

onde:

$c_{h}=$ parcela de perda da cultura $h$ em relação à perda total;

$E S_{h} N=$ efeito substituição negativo da cultura $h ; \mathrm{e}$

$\sum E S N=$ somatório do efeito substituição negativo de todas as culturas.

O ganho de área experimentado por uma determinada cultura $h$ que teve $o$ efeito substituição positivo é dado por:

$$
g_{h}=\left(E S_{h} P\right) c_{h}
$$

onde:

$g_{h}=$ ganho de área da cultura $h$ que teve efeito substituição positivo; e $E S_{h} P=$ efeito substituição positivo de um determinada cultura $h$.

e) Índice de reestruturação de cultivo

Neste estudo, o indice de reestruturação de cultivo foi definido como a participação percentual da área substituída (substituta) da h-ésima lavoura, no total de área disputada no i-ésimo estrato de área total. Visando atender os objetivos deste trabalho, procederar-se-á uma apresentação detalhada apenas para a cultura da mandioca ( $\mathrm{h}=$ mandioca), usando-se o seguinte procedimento: 


$$
\operatorname{IREC} C_{h}=\left(\frac{A S_{h i}}{A D_{i}}\right) 100
$$

onde:

$I R E C_{h}=$ indice de reestruturação de cultivo da h-ésima lavoura;

$A S_{h i}=$ área substituida (substituta) da h-ésima lavoura no l-ésimo estrato de área total; e

$A D_{i}=$ área total disputada no i-ésimo estrato de área total.

\subsection{Fontes dos DADOS}

Os dados utilizados foram de diversas fontes. Prioritariamente, foram utilizados dados secundários de séries temporais das seguintes instituições:

i) FGV: IGP-DI (Índice Geral de Preços - Disponibilidade Interna) coluna 2, preço recebido pelos produtores de mandioca, custo de mão-de-obra rural e preço recebido pelos produtores de trigo, milho e soja;

ii) IBGE - Anuário Estatístico do Brasil: área, rendimento médio, produção de diversas culturas, e volume de crédito rural - Censo Agropecuário: estrato de área total por cultura;

iii) CONAB - Companhia Nacional de Abastecimento: preços mínimos e preço de farinha de mandioca na Região Nordeste;

iv) EMBRAPA - Empresa Brasileira de Pesquisa Agropecuária: volume de recursos investidos na geração de tecnologia para mandioca;

v) DISME - Distrito Meteorológico do Departamento Nacional de Meteorologia: pluviosidade média; e

vi) BACEN - Banco Central do Brasil: Anuário Estatístico do Crédito Rural. 


\subsection{PRINCIPAIS HIPóteses a SEREM TESTAdAS}

Tendo em vista as considerações referentes aos fatores associados à produção de mandioca e os modelos apresentados, podem ser formuladas as seguintes hipóteses a respeito das relações entre o desempenho dessa cultura e as políticas públicas orientadas para o setor agrícola, no Brasil, nos últimos anos. Uma primeira hipótese a ser testada é a de que a produção de mandioca está associada a pelo menos dois grupos de produtores. Essa hipótese foi testada por meio da verificação da significância estatística das regressões obtidas nos dois modelos propostos (modelo I e modelo II).

Uma segunda hipótese é a de que as políticas públicas, isto é, a política de preço, a política de crédito, a política de mudança tecnológica e as políticas de incentivos diferenciados, afetaram o desempenho da cultura da mandioca nos últimos anos. O nivel de significância e a investigação dos sinais dos coeficientes das regressões estimadas com base nos modelos I e II, foram os indicadores utilizados para testar esta hipótese. Além disso, utilizou-se os resultados obtidos da análise do perfil da distribuição do crédito rural, pressupondo-se que quando há concentração, isso será um indicativo das distorções na política de crédito e conseqüentemente do impacto negativo no desempenho da cultura. $E$, complementarmente considerou-se a contribuição do rendimento físico por unidade de área, obtido no modelo "shift-share", como um indicador para testar a referida hipótese, no tocante à política de mudança tecnológica. Já os efeitos escala e substituição e o indice de reestruturação de cultivo (IREC), foram usados para se verificar o desempenho da mandioca frente às outras culturas, principalmente aquelas que foram beneficiadas com as politicas de incentivo diferenciado.

A segunda hipótese pode ser desagregada em função das políticas especificas, permitindo assim a proposição de hipótese adicionais, tais como: 
(1) Se a política de preço minimo foi eficiente para os produtores de mandioca, então a produção da cultura responderá significativamente e de forma positiva aos preços mínimos de garantia;

(2) a politica de crédito rural deve ter uma maior influência sobre os produtores da Região Centro-Sul. Considerando-se que o volume de crédito rural na década de 80 , comparativamente à década de 70 , foi menor, é provável que, além de uma redução na participação relativa, o perfil de distribuição do crédito rural para a cultura da mandioca tenha piorado naquela década;

(3) apesar do fraco desempenho do produto nos últimos anos, os produtores de mandioca devem responder positivamente aos investimentos em tecnologia. Sendo que, a exemplo da política de crédito, espera-se que os produtores da Região Centro-Sul responda com uma maior intensidade. Mas, ressalta-se, que provavelmente o rendimento físico por unidade de área não foi a fonte de crescimento (positiva ou negativa) da produção de maior relevância para a cultura nas décadas de 70 e 80 . Pois, além do mercado enfrentado pelo produto (instabilidade de preços recebidos) não ser favorável à incorporação de tecnologias, as condições agroambientais onde foram implantadas, a cultura não favoreceu a uma resposta positiva aos investimentos em tecnologias;

(4) que a cultura da mandioca foi fortemente substituída nas últimas década é um consenso. Todavia, essa competição com os produtos beneficiados com as politicas de incentivo diferenciado deve ter sido mais acirrada nos estratos de área superior a 100 ha. 


\section{RESULTADOS}

\subsection{Política de Crédito}

\subsubsection{Resultados de Outros Estudos}

No meados dos anos 60 , importantes reformas foram realizadas na área monetária brasileira. Dentre essas reformas, merece citação a criação do Sistema Nacional de Crédito Rural (SNCR), o qual era um instrumento chave da estratégia de modernizar o setor agrícola através do estímulo ao uso de tecnologias modernas.

A partir da implementação da politica de crédito rural no Brasil, muitos estudos foram realizados com o objetivo de avaliar os efeitos dessa politica no comportamento do setor agricola. Nesta seção serão apresentados alguns resultados obtidos por outros autores, procurando-se identificar, quando possivel, os aspectos relevantes para a cultura da mandioca.

A politica de crédito rural conduzida a partir da criação do SNCR apresentou graves distorções identificadas em diversos estudos. A constatação de que na década de 70 , houve uma excessiva concentração dos benefícios do crédito entre os grandes agricultores, os produtos agricolas voltados para o mercado externo e a produção de energia, e em favor das regiões Sudeste e Sul, é um consenso entre os diversos estudiosos do assunto. Por exemplo, ARAÚJO (1980) verificou que, no período 1969-79, para o crédito agricola de custeio apenas 7 (sete) culturasconcentraram ao redor de $3 / 4$ do custeio total. Segundo ele "(...) esta 
evidência pode, inclusive, explicar parcialmente o perfil distributivo do crédito tanto a nivel regional como de unidade produtiva"(1).

Nesta direção, os estudo realizados por REGO (1980) para o periodo de 1969-76, apontam que "(..) as lavouras básicas recebem crédito muito menos que proporcionalmente à sua contribuição ao valor da produção agrícola, em comparação com os produtos de exportação. Isto evidencia uma concentração do crédito rural a nivel de produto".

Por outro lado, HOFFMANN \& KAGEYAMA (1987) usando a redundância para medirem a distribuição de crédito rural em relação ao valor da produção, verificaram que no Brasil, entre 1970 e 1980, ocorreu um processo de desconcentração do crédito. Esses autores consideraram a distribuição regional do crédito rural assim como a distribuição entre várias culturas. De certa forma, os resultados encontrados por eles contrariam as expectativas criadas pela maioria dos analistas durante a década de 70 a respeito das tendências concentradoras e excludentes do crédito rural no Brasil. Simon citado por CARDOSO (1994) também verificou um processo de desconcentração espacial do crédito no periodo de 1970 a 1979 , observando esse autor queda em termos de participação relativa nos recursos da região Sudeste e elevação das regiōes Nordeste e Centro-Oeste.

BARNES MOLINAR (1984) estudando a evolução do crédito de custeio e da produção de determinados produtos agrícolas, no Brasil, no período de 1967 a 1981, verificou que no sub-periodo de $1967 / 76$ a cultura da mandioca apresentou uma taxa de crescimento da produção igual a $-2,60 \%$, enquanto a taxa de crescimento do custeio agricola para a cultura foi de $11,58 \%$. No sub-periodo seguinte $(1977 / 81)$, a taxa de crescimento da produção foi de $-1,49 \%$ contra $53,02 \%$ para o crédito de custeio agricola. Note-se que no periodo analisado pelo autor, as taxas de crescimento da produção da mandioca parecem que não estão relacionadas com as

(1) As culturas estudadas foram algodão, arroz, café, cana-de-açúcar, milho, soja e trigo. 
taxas de crescimento do crédito para custeio agricola da cultura. Essa constatação está de acordo com os resultados encontrados por FAGUNDES (1987, p.64), quando no período de 1970 a 1985 considerou o comportamento agregado de outras culturas como: arroz, feijão, milho, trigo, soja, algodão e amendoim. O estudo conduzido por REGO (op. cit.) além de verificar a fraca relação entre crédito rural recebido pelos produtores e a sua respectiva contribuição ao valor da produção, identifica que o crédito rural relaciona-se mais fortemente com o tamanho da propriedade.

Analisando a relação valor bruto da produção/crédito para custeio agrícola no período de 1969 a 1981 BARNES MOLINAR (op. cit.) observou que dos produtos analisados $(2)$ a mandioca sempre apresentou a maior relação. Isso significa que no agregado a cultura da mandioca estava produzindo, em valor, por cada cruzeiro de crédito de custeio agricola concedido, muito mais do que os demais produtos estudados. Em outras palavras, considerando-se o valor da produção, proporcionalmente, a mandioca foi uma cultura sempre preterida na distribuição do crédito para o custeio agrícola, naquele período.

SHIROTA (1988) analisando a distribuição do crédito rural em relação ao valor da produção agropecuária por estrato de área, no Brasil, nos anos de 1970, 1975 e 1980 encontrou resultados coerentes com os obtidos por BARNES MOLINAR (op. cit.) e HOFFMANN \& KAGEYAMA (op. cit.). Segundo ele "(..) apesar da concentração verificada em 1975 , relativamente à 1970 , no período $1975-1980$ houve considerável melhoria da distribuição do crédito, no que se refere à participação dos estratos no valor da produção. A redundância foi estimada, respectivamente, em $0,1267,0,1486$ e 0,0657 nos anos 1970,1975 e $1980 "$.

(2) Os demais produtos analisados são: algodão, arroz, café, milho, soja, trigo, amendoim, cacau, cana, feijão, laranja, batata e fumo. A mandioca apresentou um quociente que varia de 6,1 (ano de 1981) a 73,7 (ano de 1974). Por outro lado, o quociente médio do trigo nos 13 anos estudados foi de 1,8 , indicando como esta cultura foi beneficiada pela política de crédito. 
Continuando, SHIROTA (1988) revela que "(...) a redundância dentro de estratos apresenta uma taxa de redução proporcionalmente maior que a redundância entre estratos". As participaçōes relativas encontradas pelo autor entre estratos e dentro de estratos são respectivamente $82,2 \%$ e $17,8 \%$ para o ano de 1970 e, $87,8 \%$ e 12,2\% para o ano de 1980. O autor argumenta que "(...) isto indica que houve uma significativa melhoria na distribuição dos recursos financiados no sentido de torná-los mais compativeis com a participação de cada estrato no valor global da produção". Ao finalizar a análise, esse autor constata que os índices de concentração do crédito rural em relação ao valor da produção por estrato de área desagregado por região, em geral, mostra tendência semelhante à observada para o país como um todo.

Outro aspecto importante que foi bastante considerado nos estudos com crédito rural no Brasil, refere-se à sua relação com a modernização da agricultura. Aqui a modernização considerada é aquela que "(..) está centrada em dois elementos fundamentais: (1) o crescimento da utilização por parte da agricultura, de máquinas e equipamentos agrícolas; e (2) o crescimento no uso de fertilizantes e defensivos químicos" (BARNES MOLINAR, op. cit.). Para esse autor "(..) a modernização da agricultura brasileira, em termos de regiões e produtos, esteve associada durante o periodo estudado por ele, a niveis crescentes de consumo de crédito"(3). Concluindo, ele revela que ficou comprovada, a relação entre modernização e o volume de crédito. Nessa mesma direção ARAÚJO (op. cit., p.65) considera que até 1976 o crédito mostrou-se positivamente correlacionado com o uso de insumos modernos.

A vinculação do crédito rural subsidiado com o consumo de insumos modernos era realmente bastante forte. Nesse sentido SANTOS (1988) fornece uma argumentação considerável. Ele diz que "(...) dos objetivos do programa de crédito rural, pode-se afirmar que a promoção da modernização da agricultura, através do

(3) O período estudado pelo autor foi de 1969 a 1981. 
incentivo ao uso de insumos modernos, foi o mais seriamente perseguido pelo Governo. Mesmo nos empréstimos aos pequenos produtores, (...) era obrigatório constar, nos projetos, 0 item de utilização de insumos modernos (principalmente fertilizantes). Modernizar a agricultura significava utilizar insumos industriais na agricultura".

A outra crítica que é freqüentemente feita à politica de crédito rural e que também foi alvo de estudos, está relacionada com os subsidios. Esses levam a desajustamentos nos mercados de produtos e fatores, gerando ineficiências tanto no uso dos recursos produtivos como na combinação dos produtos agropecuários.

Os estudos referentes aos subsídios ao crédito rural, foram na sua maioria dirigidos para o cálculo dos subsídios implícitos nas taxas de juros cobradas do setor agrícola e para a avaliação do impacto dessa concessão no desenvolvimento desse setor. Dentre esses estudos, no Brasil, podem ser citados os desenvolvidos por ARAÚJO (1980), SAYAD (1984), SHIROTA (1988) e MESQUITA (1994).

GONZÁLEZ VEGA (1987b) considera que como as taxas de juros subsidiados não refletem o custo e o risco associados à prestação de serviço dos agentes financeiros, cria-se uma distorção perversa na politica de crédito rural, e conseqüentemente não têm sido atingido os objetivos de atender a determinados estratos de produtores rurais. Segundo o autor, tipicamente os tomadores de crédito que deveriam ser favorecidos com taxas de juros preferenciais, como é o caso dos pequenos produtores, estão associados com os custos e os riscos mais elevados para os agentes financeiros. Às vezes os agentes financeiros são forçados a cobrar taxas de juros mais baixas precisamente àqueles produtores que desejariam cobrar taxas mais altas. Como resultado desta discrepância, o estrato dos produtores (pequenos produtores) que as autoridades desejariam favorecer tem sido o mais prejudicado em função do racionamento do crédito. 
O autor supracitado, considera que as taxas preferenciais para favorecer a agricultura têm contribuido significativamente para concentrar os empréstimos das instituições formais de crédito e têm acentuado as restrições ao acesso ao crédito institucional. Além desses impactos diretos, indiretamente as taxas de juros subsidiadas criam nos agentes financeiros critérios para favorecer 0 acesso ao crédito, indo privilegiar sobretudo os grandes produtores, de menor risco e mais conhecidos.

Em trabalho conduzido por MESQUITA (1994), verificou-se que um dos aspectos mais importantes da política de crédito rural no período de $1970 / 90$, foi a presença de um volume considerável de subsidios implícitos, repassados aos agricultores através da prática de juros reais negativos. No periodo analisado pelo autor, apenas nos anos de 1984 e 1990 é que ocorrem inversão do processo, ou seja, encargos financeiros positivos, embora pequenos.

\subsubsection{O Crédito Rural e a Cultura da Mandioca: Análise dos Resultados}

$\mathrm{Na}$ avaliação da política de crédito rural geralmente são contempladas diversas dimensões de análise. No caso do presente trabalho, foram consideradas pelo menos os aspectos relacionados com a "eficácia" da política, ou seja, com a possibilidade de substituição e a distribuição, sendo estes de alguma forma correlacionados com o subsídio implícito. As análises efetuadas a seguir estão de acordo com o estabelecido nas considerações teóricas a respeito da política de crédito rural. Vale ressaltar que geralmente os produtores de mandioca só têm acesso ao crédito rural para as finalidades de custeio ou comercialização, embora seja esta última modalidade em menor volume.

Orientada pela justificativa de beneficiar o setor agricola, como uma forma de estímulo compensatório às diferentes adversidades (instabilidade de preços, risco 
climático, incidência de pragas e doenças e as inúmeras taxações), a política de crédito rural concedeu aos produtores taxas de juros privilegiadas em relação aos outros setores da economia. ARAÚJO (1980) aponta alguns traços marcantes dessa politica. Segundo ele, um desses traços "(...) é que os pequenos agricultores devem ser estimulados a contrair empréstimos através de juros ainda menores, e mais negativos".

Diante do exposto como a cultura da mandioca é geralmente cultivada por pequenos produtores isso implica que eles serão beneficiados com taxas de juros que apresentam aquelas caracteristicas, ou seja, com algum grau de subsidio implícito. Esse subsidio deve ter provocado como conseqüência, maior racionamento de crédito para a cultura da mandioca e ineficiência na alocação dos fatores de produção envolvidos no processo produtivo. Aliás, esse comportamento era esperado nessa situação, conforme já identificado na literatura especializada. E como resultado final, redução da parcela do crédito orientado para a cultura da mandioca e pouco impacto no processo de modernização da mesma. A seguir serão apresentados alguns indícios do processo de racionamento de crédito para a cultura da mandioca.

O volume de crédito aplicado na cultura da mandioca que já era bastante reduzido em $1969,1,2 \%$, alcançou apenas, $0,39 \%$ do total de crédito para custeio no ano de 1990 (Tabela 5). Essa situação pode ser considerada como uma conseqüência dos efeitos do processo de racionamento do crédito para a cultura. Em outras palavras, a redução do crédito para custeio como um todo, no final da década de 80 , pode ter levado a uma diminuição da participação dos produtores de mandioca no volume total de crédito aplicado. Isso pode ter ocorrido em virtude do racionamento induzido pelos agentes financeiros, pois, como se sabe, eles orientam os recursos para os produtos de maior rentabilidade e/ou produtores que oferecem maior reciprocidade. Uma explicação alternativa para essa situação pode ser formulada analisando-se o problema pelo lado da demanda. Isto é, pode ter ocorrido 
uma menor demanda por crédito para a cultura da mandioca, levando-se em consideração que naquele periodo os preços recebidos pelos produtores desse produto estavam em declínio (Figura 02, seção 2.1), não sendo recomendado se contrair empréstimos nessa situação. Na verdade, deve ter ocorrido uma convergência dos fatores, tanto do lado da oferta como da demanda.

Tabela 5 - Participação relativa da cultura da mandioca no volume total do crédito rural para custeio, Brasil, 1969, 1973, 1977, 1980, 1985 e 1990.

\begin{tabular}{cc}
\hline Ano & Participação relativa no crédito (\%) \\
\hline 1969 & 1,20 \\
1973 & 0,70 \\
1977 & 1,00 \\
1980 & 2,46 \\
1985 & 1,82 \\
1990 & 0,39 \\
\hline
\end{tabular}

Fonte: Anos 1969, 1963 e 1977, BARNES MOLINAR (1984) - Tabela 2 do Apêndice, os demais anos Tabela 6 deste estudo.

A comprovação da hipótese de um maior "desvio" (substituição) de crédito por parte dos produtores de mandioca que tiveram acesso a essa política, foi assumido anteriormente como uma tarefa bastante dificil. Entretanto, arrisca-se algumas considerações. O período de 1974 a 1983 é considerado em geral, como um período em que o crédito agrícola foi muito subsidiado no Brasil (ver por exemplos, SHIROTA, 1988, pp. 107-9 e MESQUITA, 1994, p.67). Nesse periodo, a participação no crédito agricola de custeio para os produtores de mandioca, passou de $0,36 \%$ para $1,06 \%$ respectivamente. Em valores constantes houve um incremento de $332,85 \%$ (taxa 
geométrico de $17,68 \%$ a.a. $)^{(4)}$. No entanto, nesse mesmo período, a área, a produção e o rendimento físico por unidade de área da cultura da mandioca, experimentaram uma redução de $2,02 \%, 17,64 \%$ e $15,95 \%$ respectivamente. Isto significa que as fontes de crescimento da produçäo não responderam positivamente aos incentivos do crédito. O que pode implicar em que os efeitos negativos ("desvios" - substituição) de uma política de crédito subsidiada, interagindo com outros fatores, convergiram para proporcionar redução de área, produção e rendimento físico no periodo de 1974 a 1983 . E claro que como os dados estão agregados para o Brasil, a análise acima pode estar apresentando alguns vieses.

Diante disso, não se pretende aprofundar no momento a presente discussão, preferindo-se concentrar esforços, na apresentação dos resultados desta pesquisa com relação aos aspectos distributivos do crédito agricola, com enfoque na cultura da mandioca. Ademais, esse procedimento é apoiado pelo fato de que dentre as distorções geradas na implementação do sistema de crédito rural, o que quase todas as análises colocam em relevo, são as discussões no âmbito da distribuição do crédito. Contudo, ressalta-se que ao contrário do enfoque dado neste trabalho, essas análises foram elaboradas apenas com base no comportamento agregado das culturas/atividades mais importantes do setor agrícola.

Para análise em termos agregados, ou seja, para o conjunto das culturas, o periodo considerado foi a década de 80 , pois, para a década anterior entende-se que já existe uma gama de estudos, conforme alguns resultados que constam da seção 4.2.1.

Inicialmente, pode-se adiantar que tanto no aspecto do comportamento agregado das culturas como no caso especifico da cultura da mandioca, observou-se uma tendência de concentração do crédito na década de 80 comparativamente à de

$\left({ }^{4}\right)$ Passou de U $\$ 25,784,164.00$ para U $\$ 111,624,280.00$ (dólar médio de dezembro de 1992). Fonte dos dados básicos, Anuário Estatisticas do Crédito Rural, 1974 e 1983 - BACEN. Cálculos do autor 
70. Esses resultados de piora no perfil distributivo do crédito de custeio agrícola na década de 80 estão de acordo com os obtidos por GATTI et alii (1993). Segundo esses autores isso também já havia sido observado por Rodrigues Junior em 1986.

Na Tabela 6 tem-se a distribuição percentual das 13 culturas que em 1990 absorveram uma grande parcela $(90,8 \%)$ do crédito de custeio. Da análise dessa Tabela pode-se verificar que em 1980, 4 (quatro) culturas (soja, café, arroz e milho, nesta ordem) participaram com quase $63 \%$ do crédito de custeio. Em 1985 o processo de concentração é ampliado, chegando as 4 (quatro) culturas (soja, arroz, milho e cana-de-açúcar) a uma participação de $73,34 \%$. Por outro lado, em 1990, há uma ligeira redução da concentração do crédito, comparativamente ao ano de 1985 , entretanto o mesmo não acontece em relação ao ano de 1980 . Naquele ano as 4 (quatro) culturas (soja, milho, cana-de-açúcar e arroz) foram beneficiadas com $69,31 \%$ do crédito rural para custeio. Além da tendência de concentração, um fato que merece destaque é a inclusão da cana-de-açúcar entre as culturas que mais obtiveram crédito nos anos de 1985 e 1990 . Essa cultura passou de uma participação no crédito de $8,13 \%$ para $14,79 \%$ respectivamente nos anos de 1980 e 1990 . Todavia, as suas participações relativas na área colhida e no valor da produção não aumentaram na mesma proporção (Tabela 7).

Ainda com base na Tabela 6 , no tocante à cultura da mandioca, observa-se uma tendência de redução na participação do crédito para custeio. Para que se tenha uma idéia dessa redução, enquanto a cana-de-açúcar, por exemplo, aumentou a participação em $81,92 \%$, no período de $1980-90$, a mandioca reduziu a sua parcela em aproximadamente $84 \%$, sendo esse valor inferior apenas ao da cultura do cacau que alcançou uma redução de quase $90 \%$. 
Tabela 6 - Participação relativa das principais culturas no valor total do crédito rural para custeio, Brasil, 1980, 1985 e 1990.

\begin{tabular}{lccc}
\hline Culturas & \multicolumn{3}{c}{ Participação relativa no valor do crédito para custeio (\%) } \\
\cline { 2 - 4 } & $\mathbf{1 9 8 0}$ & $\mathbf{1 9 8 5}$ & $\mathbf{1 9 9 0}$ \\
\hline Algodão & 6,34 & 6,88 & 7,71 \\
Amendoim & 0,43 & 0,45 & 0,27 \\
Arroz & 14,67 & 19,08 & 12,86 \\
Batata & 1,37 & 0,90 & 1,97 \\
Cacau & 1,24 & 0,92 & 0,13 \\
Café & 16,10 & 7,03 & 7,16 \\
Cana-de-açúcar & 8,13 & 10,29 & 14,79 \\
Feijão & 6,75 & 3,73 & 3,83 \\
Laranja & 1,97 & 1,48 & 2,42 \\
Mandioca & 2,46 & 1,82 & 0,39 \\
Milho & 13,17 & 15,82 & 17,39 \\
Soja & 18,75 & 26,15 & 24,28 \\
Trigo & 8,62 & 5,45 & 6,80 \\
\hline Total & 100,00 & 100,00 & 100,00 \\
\hline Fon
\end{tabular}

Fonte: Dados básicos - Anuário Estatístico do Brasil/ IBGE (vários números).

Comparando-se as Tabelas 6 e 7 , observa-se que nem sempre há uma relação positiva entre a participação relativa no crédito e a participação relativa na área ou no valor da produção. Isso já havia sido identificado por diversos autores (ver seção 5.1.1). Dentro deste contexto, é necessário esclarecer, que conforme ressaltado por HOFFMANN \& KAGEYAMA (1987), não está sendo proposto que, necessariamente, o crédito deva ser distribuído proporcionalmente ao valor da produção. Segundo esses autores "(..) se há necessidade de favorecer o crescimento de determinada cultura, para atender às necessidades do abastecimento, essa cultura deverá obviamente receber mais crédito do que 0 
montante que the caberia em uma distribuição proporcional ao valor da produção no ano anterior".

Tabela 7 - Participação relativa das principais culturas na área colhida e no valor da produção, Brasil, 1980, 1985 e 1990.

\begin{tabular}{|c|c|c|c|c|c|c|}
\hline \multirow{3}{*}{ Culturas } & \multicolumn{4}{|c|}{ Participação relativa $(\%)$} & \multirow{2}{*}{\multicolumn{2}{|c|}{1990}} \\
\hline & \multicolumn{2}{|l|}{1980} & \multicolumn{2}{|l|}{1985} & & \\
\hline & $\begin{array}{l}\text { Área } \\
\text { Colhida }\end{array}$ & $\begin{array}{l}\text { Valor da } \\
\text { Produção }\end{array}$ & $\begin{array}{l}\text { Área } \\
\text { Colhida }\end{array}$ & $\begin{array}{l}\text { Valor da } \\
\text { Produção }\end{array}$ & $\begin{array}{l}\text { Área } \\
\text { Colhida }\end{array}$ & $\begin{array}{l}\text { Valor da } \\
\text { Produção }\end{array}$ \\
\hline Algodão & 7,95 & 4,59 & 7,44 & 4,91 & 4,05 & 2,96 \\
\hline Amendoim & 0,67 & 0,59 & 0,40 & 0,40 & 0,18 & 0,22 \\
\hline Arroz & 13,41 & $11 ; 44$ & 9,85 & 8,46 & 8,39 & 8,01 \\
\hline Batata & 0,39 & 2,74 & 0,32 & 1,31 & 0,34 & 4,97 \\
\hline Cacau & 1,04 & 2,75 & 1,34 & 3,67 & 1,41 & 1,67 \\
\hline Café & 5,23 & 10,62 & 5,25 & 20,25 & 6,18 & 8,99 \\
\hline Cana-de-açúcar & 5,60 & 13,32 & 8,11 & 14,35 & 9,08 & 21,96 \\
\hline Feijão & 9,98 & 8,13 & 11,02 & 4,58 & 9,95 & 5,72 \\
\hline Laranja & 1,24 & 3,87 & 1,37 & 5,73 & 1,94 & 7,99 \\
\hline Mandioca & 4,33 & 8,09 & 3,87 & 4,87 & 4,12 & 9,58 \\
\hline Milho & 24,60 & 14,39 & 24,44 & 10,86 & 24,23 & 12,34 \\
\hline Soja & 18,85 & 15,96 & 21,04 & 14,72 & 24,42 & 12,61 \\
\hline Trigo & 6,71 & 3,51 & 5,55 & 5,89 & 5,70 & 2,98 \\
\hline Total & 100,00 & 100,00 & 100,00 & 100,00 & 100,00 & 100,00 \\
\hline
\end{tabular}

Fonte: Anuário Estatístico do Brasil, IBGE (vários números) e Produção Agrícola Municipal/IBGE (vários números).

Dando continuidade a apresentação dos resultados da análise para o conjunto das 13 culturas na década de 80 , verifica-se que a distribuição do crédito em relação a distribuição da área colhida apresentou um comportamento praticamente inalterado, quando se comparam os valores da redundância estimados para os anos 1980 e 1990 (Tabela 8). Entretanto, quando se cotejam os dados dos anos de 1980 e 
1985 observa-se um valor menor para a redundância, respectivamente 0,1348 contra 0,1061 nits.

Tabela 8 - Redundância da distribuição do crédito rural em relação à área colhida e ao valor da produção das 13 (treze) culturas selecionadas(1), Brasil, 1980 , 1985 e 1990.

\begin{tabular}{cccc}
\hline Ano & \multicolumn{3}{c}{ Redundância da distribuição do crédito rural (nits) } \\
\cline { 2 - 4 } & & $\begin{array}{c}\text { Em relação à } \\
\text { área }\end{array}$ & $\begin{array}{c}\text { Em relação ao valor da } \\
\text { produção }\end{array}$ \\
\hline 1980 & Estimada & 0,1348 & 0,1040 \\
& Potencial & 5,5492 & 5,1367 \\
\hline 1985 & Estimada & 0,1061 & 0,2142 \\
& Potencial & 5,7396 & 5,5138 \\
\hline 1990 & Estimada & 0,1323 & 0,2568 \\
& Potencial & 6,3091 & 6,1180 \\
\hline
\end{tabular}

Fonte: Dados básicos - Anuário Estatístico do Brasill IBGE (vários números) e Produção Agrícola Municipal/IBGE (vários números).

(1) As culturas selecionadas (algodão, amendoim, arroz, batata, cacau, café, canade-açúcar, feijão, laranja, mandioca, milho, soja e trigo) absorveram em $1990,90,8 \%$ do total de crédito para custeio agrícola.

No caso da distribuição do crédito rural em relação ao valor da produção das mesmas culturas consideradas anteriormente, os valores das estatísticas estimadas revelam uma tendência concentradora. Ou seja, está havendo uma ampliação da discrepância entre a distribuição do crédito e a distribuição da variável considerada, no caso, o valor da produção. Os valores obtidos de redundância foram 0,1040 , 0,2142 e 0,2568 nits, para os anos de 1980,1985 e 1990 . Isto significa que no período estudado, ocorreu uma orientação do crédito para as culturas que apresentaram diferenças consideráveis (desproporcionais) na participação relativa do crédito e do valor da produção. Para ilustrar essa situação o exemplo da mandioca é bastante elucidativo. Enquanto em 1990 a participação da cultura no valor da 
produção foi de $9,58 \%$, na distribuição do crédito o valor alcançou apenas $0,39 \%$ (Tabelas 7 e 6).

Para a análise da distribuição do crédito especifico para a cultura da mandioca, analisou-se o perfil de distribuição do crédito dessa cultura nas diferentes Unidades da Federação, comparando-se com a participação na área colhida e na produção total.

Da análise da Tabela 9 pode-se concluir que a razão de concentração $\left(\mathrm{CR}_{4}\right)$ para as variáveis área colhida e produção de mandioca nas Unidades da Federação, apresenta um comportamento relativamente estável. Comportamento contrário é observado para o caso da razão de concentração da variável crédito rural Ou seja, uma certa instabilidade, com tendência crescente.

Essa Tabela também revela que na década de 70 o crédito rural para os produtores de mandioca concentrou-se mais nas Regióes Sudeste e Sul. Isso deve ter ocorrido porque essas regiões, naquele período, eram as responsáveis pelo seguimento mais dinâmico da mandiocultura nacional. Ali se instalaram as agroindústrias processadoras de farinha de raspa que por força de lei eram adicionadas à farinha de trigo.

A seguir serão apresentados os indices de redundância para a distribuição do crédito rural considerando-se apenas a cultura da mandioca, no período de 19701990. Observou-se que tanto em relação à área colhida como em relação à produção, houve uma ampliação da concentração da distribuição do crédito rural aos produtores de mandioca entre as Unidades da Federação (Tabela 10). A tendência de crescimento foi interrompida apenas no ano de 1980 , aumentando bastante no ano posterior analisado (1985). 
Tabela 9 - Razão de concentração $\left(\mathrm{CR}_{4}\right)^{(\mathrm{a})}$ para as variáveis, crédito rural, área colhida e produção relacionada com a cultura da mandioca, Brasil, 1970, $1975,1980,1985$ e 1990.

\begin{tabular}{|c|c|c|c|c|c|c|}
\hline Ano & $\begin{array}{l}\text { Participação no } \\
\text { Crédito Rural }\end{array}$ & $(\%)$ & $\begin{array}{c}\text { Participação na } \\
\text { Área Colhida }\end{array}$ & $(\%)$ & $\begin{array}{l}\text { Participação na } \\
\text { Produção }\end{array}$ & $(\%)$ \\
\hline & & & ... Estados & & & \\
\hline & Santa Catarina & 21,9 & Rio G. do Sul & 14,2 & Bahia & 13,6 \\
\hline & Bahia & 13,6 & Maranhão & 11,2 & Rio G. do Sul & 12,2 \\
\hline \multirow[t]{2}{*}{1970} & São Paulo & 12,1 & Bahia & 11,2 & Santa Catarina & 10,2 \\
\hline & Minas Gerais & 7,4 & Santa Catarina & 7,1 & Paraná & 7,2 \\
\hline \multirow[t]{3}{*}{$\mathrm{CR}_{\mathbf{4}}$} & & 55,0 & & 43,7 & & 43,2 \\
\hline & Santa Catarina & 13,6 & Bahia & 14,7 & Bahia & 19,6 \\
\hline & Minas Gerais & 12,7 & Rio G. do Sul & 13,1 & Rio G. do Sul & 12,1 \\
\hline \multirow[t]{2}{*}{1975} & Espirito Santo & 11,4 & Maranhão & 10,6 & Minas Gerais & 8,6 \\
\hline & São Paulo & 8,0 & Pernambuco & 7,7 & Paraná & 7,5 \\
\hline \multirow[t]{3}{*}{$\mathrm{CR}_{\mathbf{4}}$} & & 45,7 & & 46,1 & & 47,8 \\
\hline & Bahia & 29,4 & Maranhão & 18,3 & Bahia & 20,8 \\
\hline & Maranhão & 13,4 & Bahia & 15,1 & Maranhão & 14,0 \\
\hline \multirow[t]{2}{*}{1980} & Amazonas & 8,3 & Pernambuco & 8,9 & Minas Gerais & 8,3 \\
\hline & Pernambuco & 7,8 & Ceará & 7,7 & Rio G. do Sul & 7,3 \\
\hline \multirow[t]{3}{*}{$\mathrm{CR}_{4}$} & & 58,9 & & 50,0 & & 50,4 \\
\hline & Piauí & 37,8 & Bahia & 21,9 & Bahia & 23,0 \\
\hline & Bahia & 22,6 & Maranhão & 8,9 & Pará & 8,2 \\
\hline \multirow[t]{2}{*}{1985} & Maranhão & 20,0 & Pará & 7,8 & Paraná & 7,5 \\
\hline & Ceará & 7,4 & Pernambuco & 7,7 & Rio G. do Sul & 6,6 \\
\hline \multirow[t]{3}{*}{$\mathrm{CR}_{\mathbf{4}}$} & & 87,8 & & 46,3 & & 45,3 \\
\hline & Paraná & 31,2 & Bahia & 16,8 & Bahia & 17,1 \\
\hline & Bahia & 13,5 & Pará & 12,0 & Pará & 11,9 \\
\hline \multirow[t]{2}{*}{1990} & São Paulo & 11,4 & Maranhão & 11,7 & Piaui & 9,4 \\
\hline & Mato Grosso (*) & 10,1 & Piaui & 8,7 & Paraná & 9,0 \\
\hline $\mathbf{C R}_{4}$ & & 66,2 & & 49,2 & & 47,4 \\
\hline
\end{tabular}

Fonte: Dados básicos - Anuário Estatístico do Brasil/ IBGE (vários números), e Anuário Estatístico do Crédito Rural, 1970-1990, (BACEN).

(a) $\mathrm{CR}_{4}$ (razão de concentração - "concentration ratio"): significa o somatório da participação dos (4) quatros componentes com maior representatividade em um dado sistema, no caso, crédito rural, área colhida e produção relacionada com a cultura da mandioca.

$\left(^{*}\right)$ Incluindo o Estado do Mato Grosso do Sul. 
Esse comportamento é explicado pela oferta de crédito rural com um todo. Em outras palavras, como no ano de 1980 foi o ápice da oferta de crédito para custeio no Brasil (ver por exemplo, SHIROTA, 1988, p.40) era de se esperar que o racionamento fosse menor, proporcionando assim uma distribuição mais eqüitativa. $O$ que aliás aconteceu, pois, 0 indice de redundância foi de 0,2565 e 0,1921 nits respectivamente para a distribuição do crédito em relação à área e à produção. Situação inversa ocorreu no ano de 1985. Nesse ano, o volume de crédito para custeio foi aproximadamente $70 \%(5)$ do aplicado em 1980 . Logo, oferta menor, maior racionamento e piora nos indices de concentração (Tabela 10).

Tabela 10 - Redundância da distribuição do crédito rural para os produtores de mandioca de todas Unidades da Federação, em relação à area colhida e à produção da cultura, Brasil, 1970, 1975, 1980, 1985 e 1990.

\begin{tabular}{cccc}
\hline \multirow{2}{*}{ Ano } & \multicolumn{3}{c}{ Redundância da distribuição do crédito rural (níts) } \\
\cline { 2 - 4 } & & Em relação à área & Em relação à produção \\
\hline \multirow{2}{*}{1970} & Estimada & 0,3640 & 0,2745 \\
& Potencial & 9,9157 & 9,7031 \\
\hline \multirow{2}{*}{1975} & Estimada & 0,4346 & 0,3790 \\
& Potencial & 8,3206 & 9,2152 \\
\hline \multirow{2}{*}{1980} & Estimada & 0,2565 & 0,1921 \\
& Potencial & 8,9444 & 9,0010 \\
\hline \multirow{2}{*}{1985} & Estimada & 0,9578 & 1,0466 \\
& Potencial & 8,4743 & 8,4253 \\
\hline 1990 & Estimada & 0,8598 & 0,5760 \\
& Potencial & 7,9259 & 7,9709 \\
\hline
\end{tabular}

Fonte: Dados básicos - Anuário Estatístico do Brasill IBGE (vários números), e Anuário Estatístico do Crédito Rural, 1970-1990, (BACEN).

${ }^{5}$ ) Este valor percentual foi calculado com base nos valores apresentados por SHIROTA (1988, p.40). 
Outro aspecto importante, é que há evidências de que o crédito para os produtores de mandioca foi aplicado em maior volume nos Estados com melhor nivel tecnológico. Na Tabela 10, pode-se observar, que exceto no ano de 1985, os valores estimados para a redundância da distribuição do crédito em relação à produção foram invariavelmente menores no período estudado. Ou seja, se as distribuições (de crédito e de produção) apresentam uma menor discrepância, dado que a variável área é a mesma no ano considerado, então foi o rendimento físico que exerceu uma compensação - aumentando a produção - reduzindo assim o grau de concentração.

Para finalizar, acrescentam-se duas considerações: primeiro é que os valores máximos potenciais da redundância encontram-se nas Tabelas 8 e 10. Esses valores, refletem o caso hipotético em que todo o crédito seria aplicado em um determinado ano, na cultura ou Estado (para o caso específico da mandioca) com menor participação na variável considerada.

Segundo, é que apesar de em determinadas situações os valores estimados da redundância revelarem uma tendência à concentração do crédito, é importante ressaltar que os valores dessa estatística analisados isoladamente são relativamente baixos, variando de 0,1040 a 1,0466 nits respectivamente para a redundância da distribuição do crédito em relação ao valor da produção (conjunto das culturas Tabela 8) e em relação à produção total (apenas para a cultura da mandioca - Tabela 10). Nunca é demais lembra, que o valor mínimo dessa estatística é 0 (zero) (ver seção 4.4.1. ). A implicação disso (valores baixos) é que de certa forma, sem levar em consideração a tendência, poder-se-ia dizer que o crédito está sendo distribuido de uma forma equânime. Note-se que na presente análise não foi levado em consideração a distribuição entre produtores. Ai sim, certamente os indices de concentração são alarmantes. 


\subsection{A Política de Mudança tecnológica}

\subsubsection{Contribuição do Rendimento Físico para a Produção de Mandioca}

Em primeiro lugar, constata-se que o rendimento físico da cultura da mandioca, apesar de ter sofrido redução, apresenta-se bastante estável. Isto pode ser facilmente verificado tanto na Figura 05 como na Tabela 11. Ademais, 0 coeficiente de variação dessa variável é de apenas $12,33 \%$, indicando, portanto, uma dispersão relativamente baixa. No período $1931 / 94$ a taxa anual de crescimento do rendimento foi de $-0,27 \%$, isto revela a tendência declinante da produção por unidade de área da cultura( $(6)$.

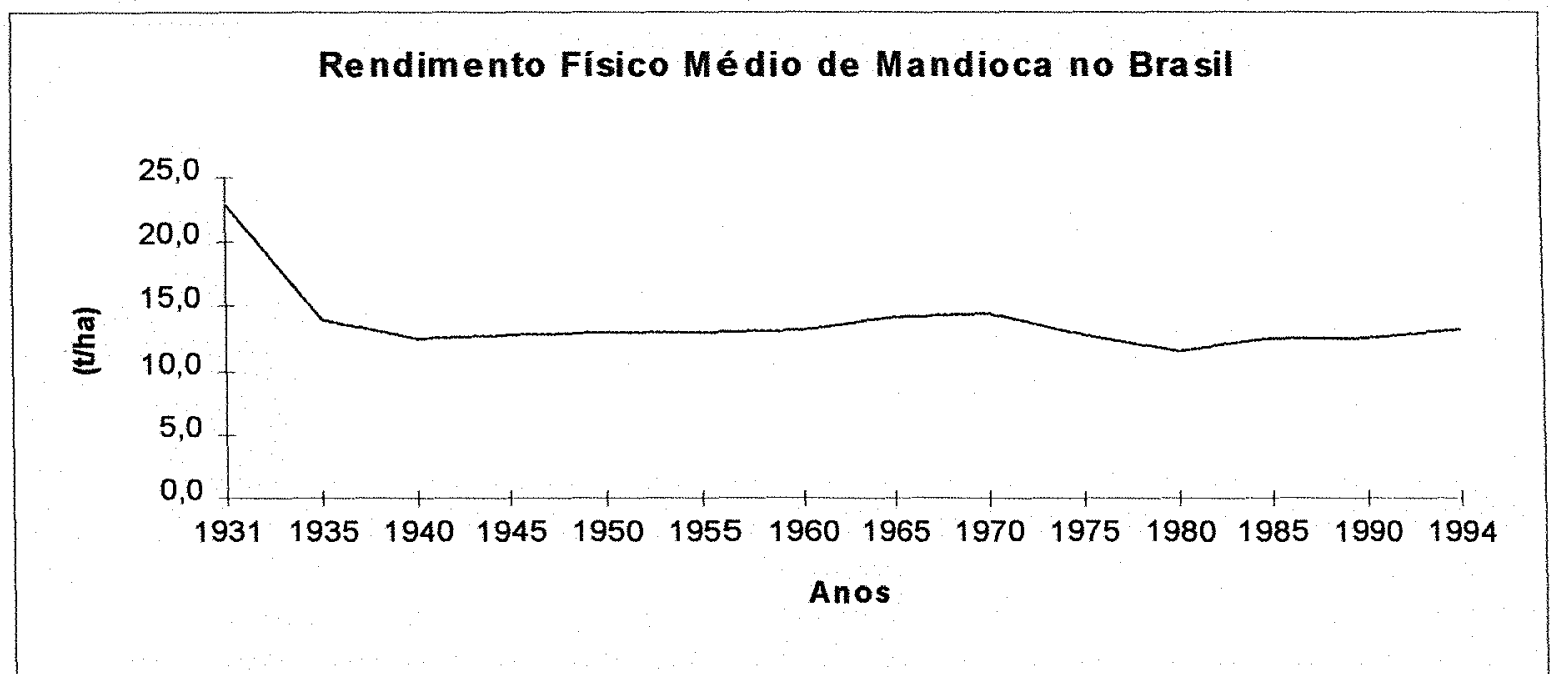

Fonte: Dados básicos - Estatísticas históricas do Brasil, IBGE, 1990; Anuário Estatístico do Brasil, IBGE (vários números) e Levantamento sistemático da produção agricola, IBGE.

Figura 05 - Evolução do rendimento físico por unidade de área de mandioca, no periodo de 1931 a 1994, Brasil.

${ }^{(6)}$ Os cálculos foram realizados com os dados básicos da Tabela 11. A determinação da taxa anual de crescimento foi feita por meio do ajustamento de uma regressão linear, sendo 0 coeficiente de determinação igual a $24,21 \%$ e o teste de $F$ significativo a $1 \%$. 
Tabela 11 - Evolução do rendimento físico médio por unidade de área $(\mathrm{Kg} / \mathrm{ha}) \mathrm{da}$ cultura da mandioca, no periodo, de 1931 a 1994, Brasil.

\begin{tabular}{|c|c|c|c|c|c|c|c|}
\hline \multirow[b]{2}{*}{ Anos } & \multicolumn{2}{|c|}{ Rendimento ( $\mathrm{Kg} / \mathrm{ha})$} & \multirow[b]{2}{*}{$\begin{array}{l}\text { Indice de } \\
\text { Rend. }\end{array}$} & \multirow[b]{2}{*}{ Anos } & \multicolumn{2}{|c|}{ Rendimento ( $\mathrm{Kg} / \mathrm{ha})$} & \multirow[b]{2}{*}{$\begin{array}{c}\text { Indice de } \\
\text { Rend. }\end{array}$} \\
\hline & $\begin{array}{l}\text { Valor } \\
\text { Corrente }\end{array}$ & $\begin{array}{l}\text { Média } \\
\text { Móvel }\end{array}$ & & & $\begin{array}{c}\text { Valor } \\
\text { Corrente }\end{array}$ & $\begin{array}{l}\text { Média } \\
\text { Móvel }\end{array}$ & \\
\hline 1931 & 22939 & & & 1963 & 13752 & 13796 & 105,3 \\
\hline 1932 & 17770 & 18161 & 138,6 & 1964 & 14194 & 14076 & 107,4 \\
\hline 1933 & 13773 & 15200 & 116,0 & 1965 & 14282 & 14120 & 107,7 \\
\hline 1934 & 14056 & 13981 & 106,7 & 1966 & 13884 & 14136 & 107,8 \\
\hline 1935 & 14113 & 14230 & 108,6 & 1967 & 14243 & 14247 & 108,7 \\
\hline 1936 & 14522 & 13854 & 105,7 & 1968 & 14615 & 14559 & 111,1 \\
\hline 1937 & 12927 & 13391 & 102,2 & 1969 & 14819 & 14663 & 111,9 \\
\hline 1938 & 12724 & 13002 & 99,2 & 1970 & 14553 & 14656 & 111,8 \\
\hline 1939 & 13355 & 12877 & 98,2 & 1971 & 14594 & 14560 & 111,1 \\
\hline 1940 & 12553 & 13051 & 99,6 & 1972 & 14532 & 13912 & 106,1 \\
\hline 1941 & 13246 & 12937 & 98,7 & 1973 & 12609 & 13167 & 100,5 \\
\hline 1942 & 13013 & 13228 & 100,9 & 1974 & 12360 & 12588 & 96,0 \\
\hline 1943 & 13425 & 13081 & 99,8 & 1975 & 12794 & 12436 & 94,9 \\
\hline 1944 & 12805 & 12980 & 99,0 & 1976 & 12153 & 12288 & 93,7 \\
\hline 1945 & 12711 & 12994 & 99,1 & 1977 & 11919 & 11973 & 91,3 \\
\hline 1946 & 13467 & 13059 & 99,6 & 1978 & 11849 & 11864 & 90,5 \\
\hline 1947 & 12998 & 13369 & 102,0 & 1979 & 11825 & 11771 & 89,8 \\
\hline 1948 & 13641 & 13347 & 101,8 & 1980 & 11641 & 11775 & 89,8 \\
\hline 1949 & 13402 & 13377 & 102,1 & 1981 & 11859 & 11615 & 88,6 \\
\hline 1950 & 13089 & 12950 & 98,8 & 1982 & 11344 & 11268 & 86,0 \\
\hline 1951 & 12358 & 12688 & 96,8 & 1983 & 10600 & 11256 & 85,9 \\
\hline 1952 & 12616 & 12544 & 95,7 & 1984 & 11824 & 11708 & 89,3 \\
\hline 1953 & 12658 & 12809 & 97,7 & 1985 & 12700 & 12337 & 94,1 \\
\hline 1954 & 13153 & 12915 & 98,5 & 1986 & 12488 & 12436 & 94,9 \\
\hline 1955 & 12934 & 13029 & 99,4 & 1987 & 12120 & 12326 & 94,0 \\
\hline 1956 & 13000 & 12958 & 98,9 & 1988 & 12371 & 12358 & 94,3 \\
\hline 1957 & 12940 & 12822 & 97,8 & 1989 & 12584 & 12503 & 95,4 \\
\hline 1958 & 12525 & 12946 & 98,8 & 1990 & 12553 & 12584 & 96,0 \\
\hline 1959 & 13374 & 13007 & 99,2 & 1991 & 12616 & 12390 & 94,5 \\
\hline 1960 & 13121 & 13188 & 100,6 & 1992 & 12002 & 12241 & 93,4 \\
\hline 1961 & 13070 & 13211 & 100,8 & 1993 & 12104 & 12457 & 95,0 \\
\hline 1962 & 13442 & 13421 & 102,4 & 1994 & 13265 & & \\
\hline \multicolumn{5}{|c|}{ Média do período } & 13231 & 13108 & 100,0 \\
\hline
\end{tabular}

Fonte: Dados básicos - Estatísticas históricas do Brasil, IBGE, 1990; Anuário Estatistico do Brasil, IBGE (vários números) e Levantamento sistemático da produção agricola, IBGE. (1) Índice de rendimento (base = média da médias móveis do período $=100$ ). 
Na Tabela 11 são apresentados os valores correntes do rendimento físico por hectare, as médias móveis de 3 anos da mesma variável e o índice de rendimento calculado com base na média das médias móveis. Observa-se pelo menos 3 (três) fases bem definidas no comportamento desse índice. A primeira, compreende o período que vai de 1934 ao final da década de 50. Nessa fase, o rendimento praticamente foi igual ao seu valor médio histórico. A partir dai inicia-se uma nova fase onde prevalece a tendência de melhora no nivel de rendimento físico ao longo do tempo, tendo o seu ápice ocorrido no final da década de 60 . Nesse periodo, 0 rendimento chegou a ser, em determinado ano, superior a aproximadamente $12 \%$ do valor tomado como base. Na última fase, ou seja, de 1974 até 1994 o rendimento sempre apresentou uma má performance. Sendo que nos anos de 1982 e 1983 o desempenho da cultura foi também prejudicado pelas condições climáticas adversas (MESQUITA, 1994, p.75).

Dentro de uma perspectiva de análise regional, há um consenso de que o comportamento do rendimento físico da cultura da mandioca está associado ao perfil da cultura nas diferentes regiões fisiográficas. Na Figura 06 , pode-se verificar que quando ocorre redução do rendimento nas regiões fisiográficas onde ele é historicamente maior, decresce o rendimento médio do país como um todo (ver também Tabela 11). Por outro lado, quando a mudança é observada na região de grande participação na produção, isto também se reflete em termos agregados. Por exemplo, nos anos de 1982 e 1983 o rendimento caiu significativamente na Região Nordeste - nessa época a participação da região na produção era respectivamente $62,98 \%$ e $63,94 \%$ - conseqüentemente houve queda no rendimento nacional.

Outra forma de abordar a contribuição do rendimento físico para a produção de mandioca, é verificando-se o comportamento do mesmo, nos diferentes estratos de área total. Na Tabela 12, verifica-se que de um modo geral, nos estratos extremos 
Tabela 12 - Área, produção, rendimento físico, índice de rendimento e participação dos estratos de área na produção de mandioca no Brasil, 1970, 1975, 1980 e 1985.

\begin{tabular}{|c|c|c|c|c|c|c|}
\hline Anos & $\begin{array}{c}\text { Estratos de } \\
\text { área }\end{array}$ & $\begin{array}{l}\text { Área } \\
\text { (ha) }\end{array}$ & $\begin{array}{c}\text { Produção } \\
\text { (t) }\end{array}$ & $\begin{array}{l}\text { Rend. } \\
\text { (Kg/ha) }\end{array}$ & $\begin{array}{c}\text { Indice de } \\
\text { Rend. }\end{array}$ & $\begin{array}{l}\text { Part. na Prod. } \\
(\%)\end{array}$ \\
\hline & $<2$ & 204476 & 1369567 & 6698 & 79,4 & 9,39 \\
\hline & $2 a-d e 5$ & 255066 & 1868643 & 7326 & 86,8 & 12,81 \\
\hline & $5 a-$ de 10 & 214824 & 1799276 & 8376 & 99,2 & 12,33 \\
\hline \multirow[t]{9}{*}{1970} & 10 a - de 20 & 292382 & 2729735 & 9336 & 110,6 & 18,71 \\
\hline & 20 a - de 50 & 391228 & 3687125 & 9424 & 111,7 & 25,27 \\
\hline & 50 a - de 100 & 161153 & 1400159 & 8688 & 103,0 & 9,60 \\
\hline & 100 a - de 500 & 163912 & 1357491 & 8282 & 98,1 & 9,31 \\
\hline & $>500$ & 45628 & 376755 & 8257 & 97,8 & 2,58 \\
\hline & otal no ano & 1728669 & 14588751 & 8439 & 100,0 & 100,00 \\
\hline & $<2$ & 192828 & 1480409 & 7677 & 86,0 & 12,68 \\
\hline & $2 a-$ de 5 & 224566 & 1874435 & 8347 & 93,5 & 16,06 \\
\hline & 5 a-de 10 & 166724 & 1542347 & 9251 & 103,6 & 13,21 \\
\hline \multirow[t]{9}{*}{1975} & 10 a - de 20 & 195208 & 1855466 & 9505 & 106,4 & 15,90 \\
\hline & 20 a - de 50 & 269208 & 2576157 & 9569 & 107,2 & 22,07 \\
\hline & 50 a - de 100 & 116597 & 1074545 & 9216 & 103,2 & 9,21 \\
\hline & 100 a - de 500 & 113939 & 1019218 & 8945 & 100,2 & 8,73 \\
\hline & $>500$ & 28159 & 249977 & 8877 & 99,4 & 2,14 \\
\hline & otal no ano & 1307229 & 11672554 & 8929 & 100,0 & 100,00 \\
\hline & $<2$ & 142287 & 1208609 & 8494 & 89,1 & 10,94 \\
\hline & $2 a-d e 5$ & 195798 & 1568750 & 8012 & 84,1 & 14,20 \\
\hline & 5 a - de 10 & 148208 & 1414159 & 9542 & 100,1 & 12,80 \\
\hline \multirow[t]{9}{*}{1980} & 10 a - de 20 & 178189 & 1901279 & 10670 & 111,9 & 17,21 \\
\hline & 20 a - de 50 & 241677 & 2523920 & 10443 & 109,6 & 22,84 \\
\hline & 50 a - de 100 & 107142 & 1050830 & 9808 & 102,9 & 9,51 \\
\hline & 100 a - de 500 & 112024 & 1058054 & 9445 & 99,1 & 9,58 \\
\hline & $>500$ & 33835 & 323907 & 9573 & 100,4 & 2,93 \\
\hline & otal no ano & 1159160 & 11049508 & 9532 & 100,0 & 100,00 \\
\hline & $<2$ & 196394 & 1390481 & 7080 & 93,1 & 11,18 \\
\hline & $2 a-$ de 5 & 232716 & 1626482 & 6989 & 91,9 & 13,08 \\
\hline & 5 a-de 10 & 196378 & 1512405 & 7701 & 101,3 & 12,17 \\
\hline \multirow[t]{5}{*}{1985} & 10 a - de 20 & 244464 & 2030609 & 8306 & 109,3 & 16,33 \\
\hline & 20 a - de 50 & 337385 & 2766198 & 8199 & 107,9 & 22,25 \\
\hline & 50 a - de 100 & 168644 & 1284370 & 7616 & 100,2 & 10,33 \\
\hline & $100 \mathrm{a}-\mathrm{de} 500$ & 192187 & 1361973 & 7087 & 93,2 & 10,96 \\
\hline & $>500$ & 67372 & 459250 & 6817 & 89,7 & 3,69 \\
\hline & otal no ano & 1635540 & 12431768 & 7601 & 100,0 & 100,00 \\
\hline
\end{tabular}

Fonte: Dados básicos - Censo Agropecuário, IBGE, 1970, 1975, 1980 e 1985. 
o rendimento físico tende a diminuir. $E$, nos estratos médios a tendência é para um melhor desempenho dessa variável. Isso pode ser explicado tanto pela associação entre disponibilidade de área e restrições agroambientais, como pelos aspectos relacionados com os objetivos da produção e sua respectiva escala de operação.

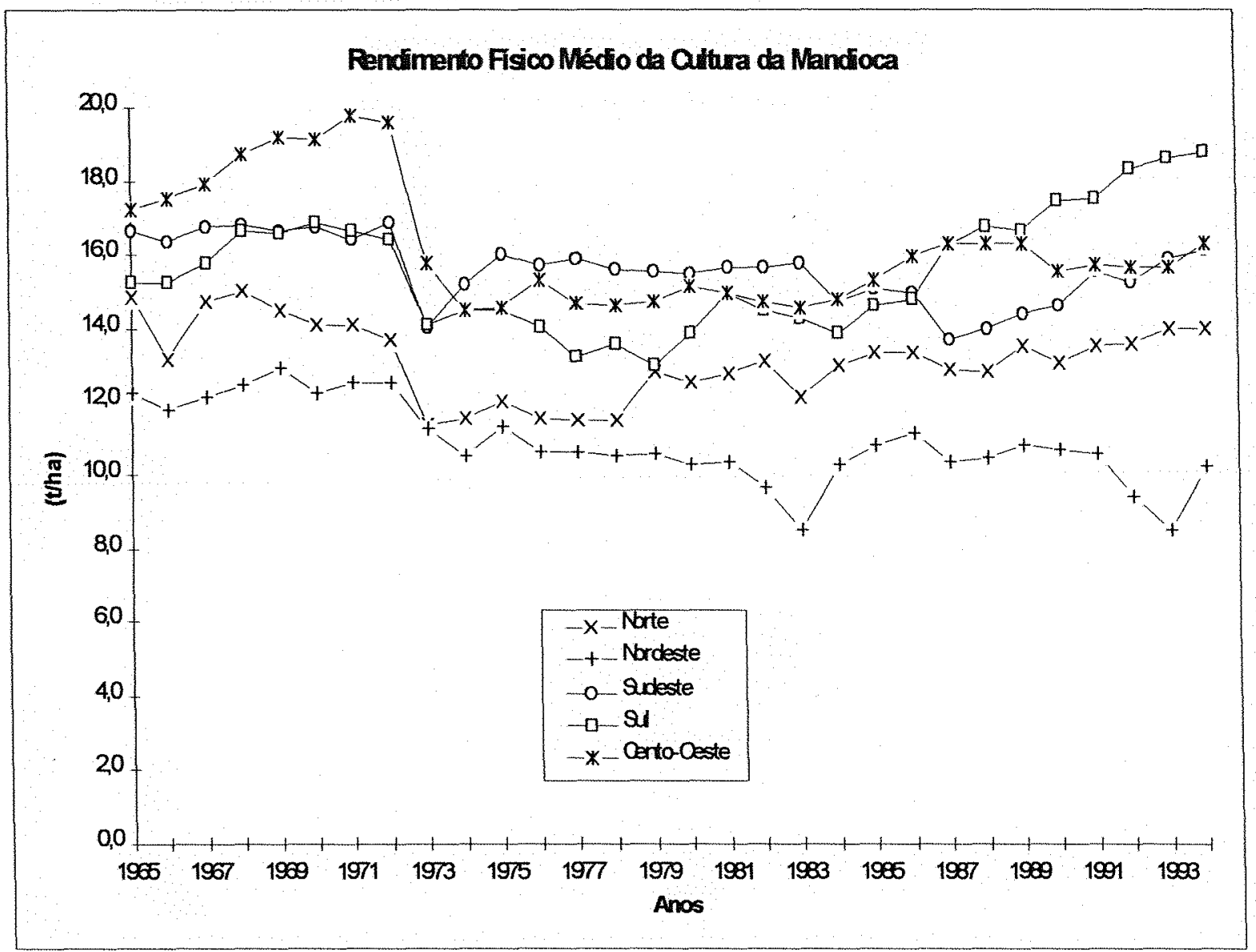

Fonte: Dados básicos - Anuário Estatístico do Brasil, IBGE (vários números).

Figura 06 - Rendimento físico médio $(\mathrm{kg} / \mathrm{ha})$ da cultura da mandioca por regióes fisiográficas, no periodo $1965 / 94$.

Em última análise, nessa discussão está envolvido o conceito de escala ótima de operação. No caso dos agricultores dos estratos menores, foi pressuposto que esses se localizavam em regiōes com maiores restrições ambientais (ver Tabela 4). Logo, a resposta aos investimentos "tradicionais" em tecnologias tende a ser menor. $E$ isso é devido a pouca possibilidade de um manejo adequado das condições 
agroambientais existentes nas unidades de produção. Em outras palavras, as limitações de área nas propriedades, impõem o cultivo sucessivo em uma mesma área o que concorre para a degradação do potencial natural do solo, uma vez que o uso das técnicas preventivas existentes até o momento, é limitado por questões econômicas.

Já no caso dos estratos maiores, a redução do rendimento deve estar correlacionada com a perda de eficiência quando a escala de operação é expandida, pressupondo-se que nestes estratos as áreas cultivadas com mandioca são maiores. Ou seja, uma maior escala de operação na atividade agricola exige, de um modo geral, a introdução de vários tipos de equipamentos que facilite a redução do custo médio unitário da produção, Como o processo produtivo da mandioca ainda requer o uso de um grande contingente de mão-de-obra, torna-se dificil seguir nesta direção, justificando assim, os baixos rendimentos quando a área é aumentada. Novamente, fatores tecnológicos estão limitando um melhor desempenho da cultura. Além disso, como nos estratos maiores, às vezes, o plantio de mandioca tem objetivo secundário (por exemplo, recuperação de pastagem) as práticas culturais são negligenciadas.

Conforme explicitado anteriormente o modelo "shift-share" permite quantificar a contribuição das diferentes fontes de crescimento para a produção de um dado produto agricola. Os resultados deste estudo, para o caso individual da mandioca estão apresentados nas Tabelas 13 e 14.

Observa-se que para o Brasil como um todo, na década de 70 a cultura da mandioca teve a sua produção reduzida, apresentando taxas de crescimento da produção de $-4,36$ e $-2,32 \%$ a.a. respectivamente nos subperiodos $1970 / 75$ e 1975/80. Em ambos subperíodos o efeito-rendimento foi positivo, contribuindo para contrabalançar os efeito-área negativo. Isto è um indicativo do nível de tecnologia usado naqueles subperíodos. Já no subperiodo 1980/85 a taxa de crescimento da 
produção foi positiva $(2,39 \%$ a.a.), mas a contribuição do efeito-rendimento foi de $5,43 \%$ a.a.. Nesse subperíodo, só não houve redução da produção porque a expansão da área foi bastante significativa $(7,84 \%$ a.a.).

Para o subperíodo 1975/85 o comportamento das fontes de crescimento da produção de mandioca foi praticamente semelhante ao periodo $1980 / 85$, embora sejam as magnitudes diferentes. Esse comportamento sugere uma tendência declinante da contribuição do efeito-rendimento. Em outras palavras, o nivel tecnológico da cultura vem piorando a partir do meados da década de 70 .

Ainda para o Brasil como um todo, a contribuição do efeito localização geográfica para as mudanças na produção de mandioca, foi praticamente desprezivel em todos os subperiodos analisados. Essa baixa magnitude do efeito localização geográfica pode ser atribuida à similaridade das técnicas de produção entre os produtores dos diferentes estratos $(7)$ o que leva a rendimentos semelhantes. Este resultado está de acordo com o encontrado por YOKOYAMA (1988), para o Estado de Goiás no período de 1975-1984. IGREJA \& CAMARGO (1992) também chegaram a resultados equivalentes no estudo realizado para o Estado de São Paulo entre 1979/81 e 1987/89. De qualquer forma, o efeito localização geográfica negativo nos subperiodos $1970 / 75$ e $1980 / 85(-0,15$ e $-0,02 \%)$ significa que aumentou a participação na produção dos estratos de área total com menor produção por hectare.

Com relação aos diferentes estratos as fontes de crescimento da produção de mandioca apresentaram o seguinte comportamento: nos subperiodos 1970/75 e 1975/80 o efeito-área foi negativo e o efeito-rendimento positivo, exceto no estrato de 2 a menos de 5 ha, no subperiodo 1975/80.

(7) O coeficiente de variação do rendimento físico médio por unidade de área nos diferentes estratos de área é de 12,39\%. Calculado com os dados básicos apresentados na Tabela 12. 
Tabela 13 - Taxas anuais de crescimento e fontes de crescimento da cultura da mandioca, por estrato de área total, $1970 / 75$ e 1975/80, Brasil.

\begin{tabular}{|c|c|c|c|c|c|c|c|c|}
\hline \multirow{3}{*}{$\begin{array}{c}\text { Estratos } \\
\text { (ha) }\end{array}$} & \multicolumn{4}{|c|}{$1970 / 75$} & \multicolumn{4}{|c|}{$1975 / 80$} \\
\hline & \multirow{2}{*}{$\begin{array}{l}\text { Taxa de } \\
\text { Crescimento } \\
\text { da Produção } \\
(\%)\end{array}$} & \multicolumn{3}{|c|}{ Fontes de Crescimento (\%) } & \multirow{2}{*}{$\begin{array}{l}\text { Taxa de } \\
\text { Crescimento } \\
\text { da Produção } \\
(\%)\end{array}$} & \multicolumn{3}{|c|}{ Fontes de Crescimento (\%) } \\
\hline & & $\begin{array}{l}\text { Efeito } \\
\text { Área }\end{array}$ & $\begin{array}{c}\text { Efeito } \\
\text { Rendimento }\end{array}$ & $\begin{array}{c}\text { Efeito } \\
\text { Localização }\end{array}$ & & $\begin{array}{l}\text { Efeito } \\
\text { Área }\end{array}$ & $\begin{array}{c}\text { Efeito } \\
\text { Rendimento }\end{array}$ & $\begin{array}{c}\text { Efeito } \\
\text { Localização }\end{array}$ \\
\hline$<2$ & 1,57 & $-4,73$ & 2,14 & 4,15 & $-3,98$ & $-2,45$ & 2,04 & $-3,57$ \\
\hline $2 a-$ de 5 & 0,06 & $-4,87$ & 2,10 & 2,83 & $-3,50$ & $-2,43$ & $-0,76$ & $-0,31$ \\
\hline 5 a - de 10 & $-3,03$ & $-5,18$ & 1,68 & 0,47 & $-1,72$ & $-2,34$ & 0,58 & 0,05 \\
\hline 10 a - de 20 & $-7,43$ & $-5,66$ & 0,32 & $-2,09$ & 0,49 & $-2,24$ & 2,15 & 0,58 \\
\hline 20 a-de 50 & $-6,92$ & $-5,60$ & 0,27 & $-1,59$ & $-0,41$ & $-2,28$ & 1,63 & 0,24 \\
\hline 50 a - de 100 & $-5,16$ & $-5,41$ & 1,02 & $-0,77$ & $-0,45$ & $-2,29$ & 1,15 & 0,69 \\
\hline 100 a - de 500 & $-5,57$ & $-5,45$ & 1,35 & $-1,47$ & 0,75 & $-2,23$ & 0,98 & 2,01 \\
\hline$>500$ & $-7,88$ & $-5,71$ & 1,33 & $-3,50$ & 5,32 & $-2,04$ & 1,25 & 6,11 \\
\hline Variação Total & $-4,36$ & $-5,32$ & 1,10 & $-0,15$ & $-1,09$ & $-2,32$ & 1,15 & 0,08 \\
\hline
\end{tabular}

Fonte: Dados básicos - Censo Agropecuário Agrícola, IBGE, 1975 e 1980. 
Tabela 14 - Taxas anuais de crescimento e fontes de crescimento da cultura da mandioca, por estrato de área total, $1985 / 80$ e 1975/85, Brasil.

\begin{tabular}{|c|c|c|c|c|c|c|c|c|}
\hline \multirow{3}{*}{$\begin{array}{c}\text { Estratos } \\
\text { (ha) }\end{array}$} & \multicolumn{4}{|c|}{$1980 / 85$} & \multicolumn{4}{|c|}{$1975 / 85$} \\
\hline & \multirow{2}{*}{$\begin{array}{c}\text { Taxa de } \\
\text { Crescimento } \\
\text { da Produção } \\
(\%)\end{array}$} & \multicolumn{3}{|c|}{ Fontes de Crescimento (\%) } & \multirow{2}{*}{$\begin{array}{l}\text { Taxa de } \\
\text { Crescimento } \\
\text { da Produção } \\
(\%)\end{array}$} & \multicolumn{3}{|c|}{ Fontes de Crescimento (\%) } \\
\hline & & $\begin{array}{l}\text { Efeito } \\
\text { Área }\end{array}$ & $\begin{array}{c}\text { Efeito } \\
\text { Rendimento }\end{array}$ & $\begin{array}{c}\text { Efeito } \\
\text { Localização }\end{array}$ & & $\begin{array}{l}\text { Efeito } \\
\text { Área }\end{array}$ & $\begin{array}{c}\text { Efeito } \\
\text { Rendimento }\end{array}$ & $\begin{array}{c}\text { Efeito } \\
\text { Localização }\end{array}$ \\
\hline$<2$ & 2,84 & 7,77 & $-4,44$ & $-0,48$ & $-0,62$ & 2,58 & $-1,00$ & $-2,21$ \\
\hline $2 a-$ de 5 & 0,73 & 8,10 & $-3,55$ & $-3,82$ & $-1,41$ & 2,67 & $-2,17$ & $-1,92$ \\
\hline 5 a-de 10 & 1,35 & 8,00 & $-5,30$ & $-1,35$ & $-0,20$ & 2,53 & $-2,11$ & $-0,62$ \\
\hline $10 a-$ de 20 & 1,32 & 8,00 & $-6,09$ & $-0,59$ & 0,91 & 2,41 & $-1,51$ & 0,01 \\
\hline 20 a - de 50 & 1,85 & 7,92 & $-5,84$ & $-0,23$ & 0,71 & 2,43 & $-1,73$ & 0,02 \\
\hline 50 a - de 100 & 4,10 & 7,57 & $-5,81$ & 2,33 & 1,80 & 2,31 & $-2,00$ & 1,49 \\
\hline $100 \mathrm{a}-$ de 500 & 5,18 & 7,41 & $-6,35$ & 4,12 & 2,94 & 2,20 & $-2,27$ & 3,02 \\
\hline$\geq 500$ & 7,23 & 7,11 & $-7,03$ & 7,15 & 6,27 & 1,88 & $-2,18$ & 6,57 \\
\hline Variação Total & 2,39 & 7,84 & $-5,43$ & $-0,02$ & 0,63 & 2,44 & $-1,81$ & 0,00 \\
\hline
\end{tabular}

Fonte: Dados básicos - Censo Agropecuário Agrícola, 1975, 1980, 1985. 
Nos demais subperiodos analisados, o comportamento foi generalizadamente 0 inverso dos anteriores. Convém ressaltar, que a dinâmica do comportamento da produção, de um modo geral, foi estabelecida pela amplitude do efeito-área. Isso acaba confirmando a hipótese de pouca relevância do rendimento físico por unidade de área como fonte de crescimento da cultura. As exceções existentes podem ser explicadas pela magnitude do efeito localização geográfica, conforme pode ser observado na Tabela 13 (estratos de 100 a menos de 500 e maior que de 500 ha - subperiodo 1975/80) e na Tabela 14 (estratos menor que 2, de 2 a menos de 5 e de 5 a menos de 10 ha - subperíodo $1975 / 85)$.

Com relação ao efeito-rendimento nos diferentes estratos, observa-se na Tabela 13, que no subperíodo $1970 / 75$, nos estratos menores (menor que 2 , de 2 a menos de 5 e de 5 a menos de $10 \mathrm{ha}$ ), a contribuição relativa desse efeito foi maior. Todavia, nos demais subperiodos não foi possível identificar qualquer tipo de tendência.

\subsubsection{Investimentos em Pesquisa}

No periodo 1976-1994, excluídos os recursos empregados no programa de obras e de produção de sementes básicas, em média, os recursos aplicados nos diversos programas de pesquisa e desenvolvimento executados pela EMBRAPA, giraram em torno de 280 milhões de reais $(8)$. Deste total, coube à cultura da mandioca uma participação relativa média de $2,17 \%$, sendo isto equivalente a 5,7 milhões de reais.

Na Figura 07 , pode-se observar a evolução relativa dos recursos orientados para o programa de pesquisa com mandioca na EMBRAPA. Verifica-se que a partir de 1987 inicia-se o periodo de menor volume de recursos aplicados, chegando a uma $\left.{ }^{8}\right)$ Valores deflacionados pelo IGP-DI (FGV), ago94=100. 
participação de apenas $1,17 \%$ (anos de 1990 a 1992). Já em 1994, por conta da injeção de recursos oriundos dos projetos executados em parceria com algumas instituiçóes internacionais, a tendência declinante foi revertida, alcançando uma participação relativa de $4,11 \%$ (Tabela 15$)$.

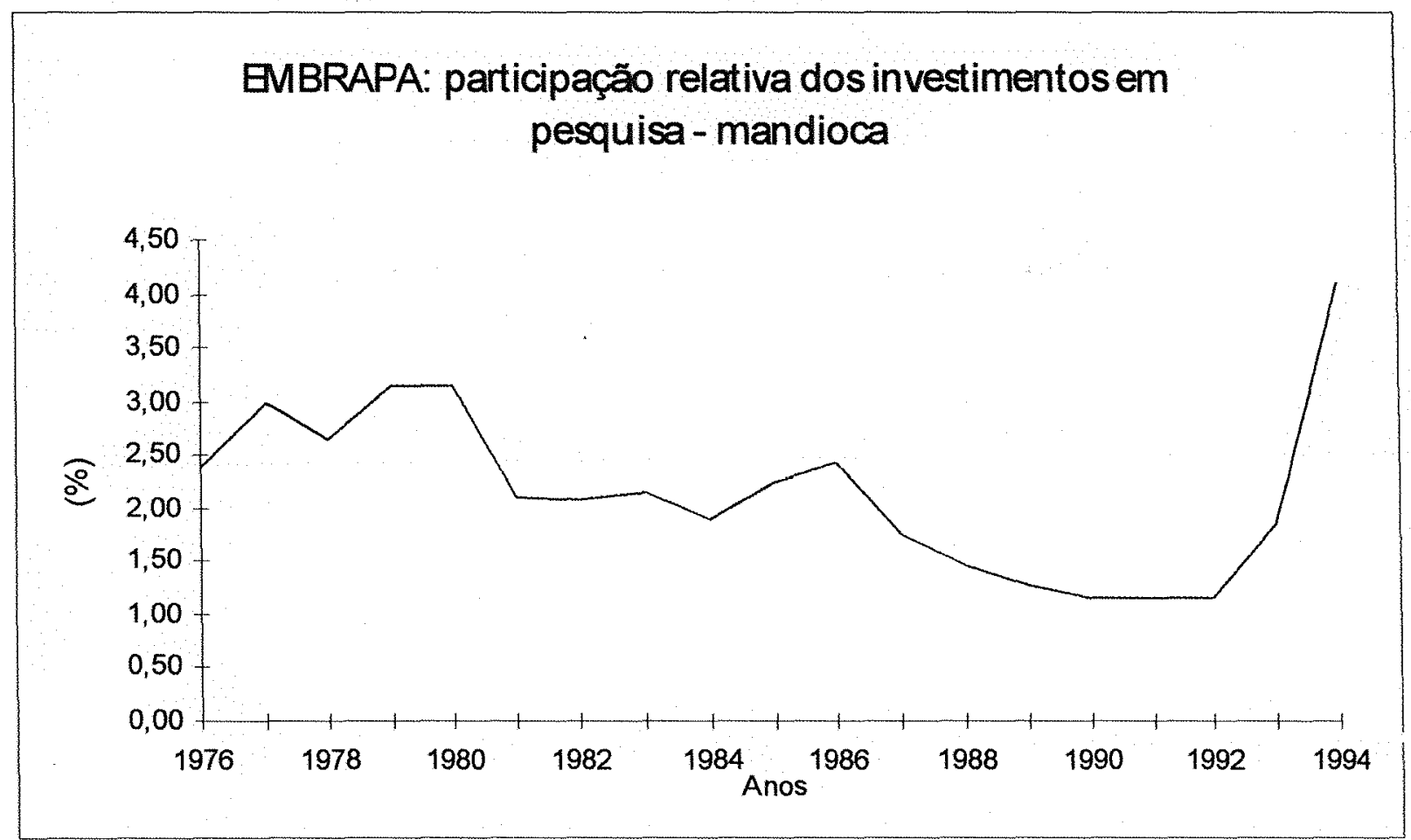

Fonte: Dados básicos - EMBRAPA

Figura 07 - Participação relativa dos recursos aplicados pela EMBRAPA para a pesquisa em mandioca, 1976-1994.

Comparando-se com outros produtos, por exemplo, milho, trigo e soja, observa-se que em termos médio, relativamente, a cultura da mandioca participou com uma parcela inferior no total dos recursos aplicados em pesquisa pela EMBRAPA(9) (Tabela 15).

(9) Excluindo-se os recursos aplicados nos programas de obras e produção de sementes básicas. 
Contudo, considerando-se a posição que a cultura ocupa na economia nacional, poderse-ia admitir que o montante de recursos estaria eqüitativamente compativel. Por outro lado, outras restrições estão contribuindo para que os investimentos em pesquisa não apresentem os impactos desejados nas técnicas de produção utilizadas pelos agricultores de mandioca, havendo, portanto, a necessidade de maiores investimentos visando a identificação dessas restrições.

Tabela 15 - Participação relativa dos recursos aplicados pela EMBRAPA para a pesquisa em mandioca, milho, trigo e soja, 1976 a 1994.

\begin{tabular}{lcccc}
\hline Anos & Mandioca & Milho & Trigo & Soja \\
\hline 1976 & 2,38 & 4,70 & 5,72 & 5,57 \\
1977 & 3,00 & 4,78 & 4,59 & 5,02 \\
1978 & 2,65 & 4,31 & 3,68 & 4,31 \\
1979 & 3,15 & 4,18 & 3,41 & 4,55 \\
1980 & 3,15 & 4,18 & 3,41 & 4,55 \\
1981 & 2,12 & 2,61 & 1,55 & 2,97 \\
1982 & 2,08 & 1,58 & 1,57 & 1,68 \\
1983 & 2,15 & 1,50 & 1,80 & 1,89 \\
1984 & 1,91 & 1,81 & 2,80 & 2,43 \\
1985 & 2,24 & 5,88 & 4,41 & 5,22 \\
1986 & 2,43 & 3,35 & 3,63 & 4,91 \\
1987 & 1,76 & 3,84 & 3,76 & 3,73 \\
1988 & 1,45 & 4,45 & 3,50 & 5,01 \\
1989 & 1,26 & 4,25 & 3,13 & 4,96 \\
1990 & 1,17 & 4,39 & 3,61 & 5,52 \\
1991 & 1,17 & 4,45 & 3,61 & 5,52 \\
1992 & 1,17 & 4,39 & 3,61 & 5,52 \\
1993 & 1,86 & 2,04 & 2,98 & 7,97 \\
1994 & 4,11 & 3,91 & 4,19 & 5,64 \\
\hline Média & 2,17 & 3,72 & 3,42 & 4,58 \\
\hline
\end{tabular}

Fonte: Dados básicos - EMBRAPA. 


\subsection{As Políticas dE INCENTIVO difERENCIAdo E AS TRANSFORMAÇões ESTRUTURAIS DA MANDIOCULTURA BRASILEIRA}

Além dos aspectos inerentes ao mercado, o processo de desenvolvimento da agricultura pode ser afetado tanto pelos incentivos governamentais, como pela capacidade potencial dos produtores responderem aos estímulos exógenos. Diante disto, os produtos que são incentivados por meio das políticas públicas, teoricamente, tendem a substituírem aqueles produtos que não foram beneficiados ou que não respondem a esses estímulos.

Tem-se observado, principalmente, nas regiōes onde a agricultura é mais dinâmica, uma perda relativa da participação da área plantada com mandioca em relação a área total cultivada nas respectivas regiōes (Figura 08). Essa perda de importância da cultura, decorre das mudanças experimentadas pela agricultura brasileira a partir do início da década de 70 . Dentre outros aspectos, essas mudanças, foram motivadas "(...) pelo processo de urbanização, pela abertura da economia ao mercado internacional e pelas alterações nas demandas internas e externas de alimentos e matérias-primas de origem agricola" (MARTIN \& GONÇALVES, 1995).

O processo de substituição da mandioca por outras culturas já havia sido constatado em estudos realizados por outros autores $(10)$. Por exemplo, CAMARGO (1983, p.75) verificou que, no periodo 1969/80, no Estado de São Paulo, dos 85 mil hectares de mandioca substituídos, mais de $66 \%$ foram incorporados pelas culturas da

(10) Note-se que os resultados dos estudos, não devem ser comparados extritamente, entretanto refletem a tendência do processo de substituição. 


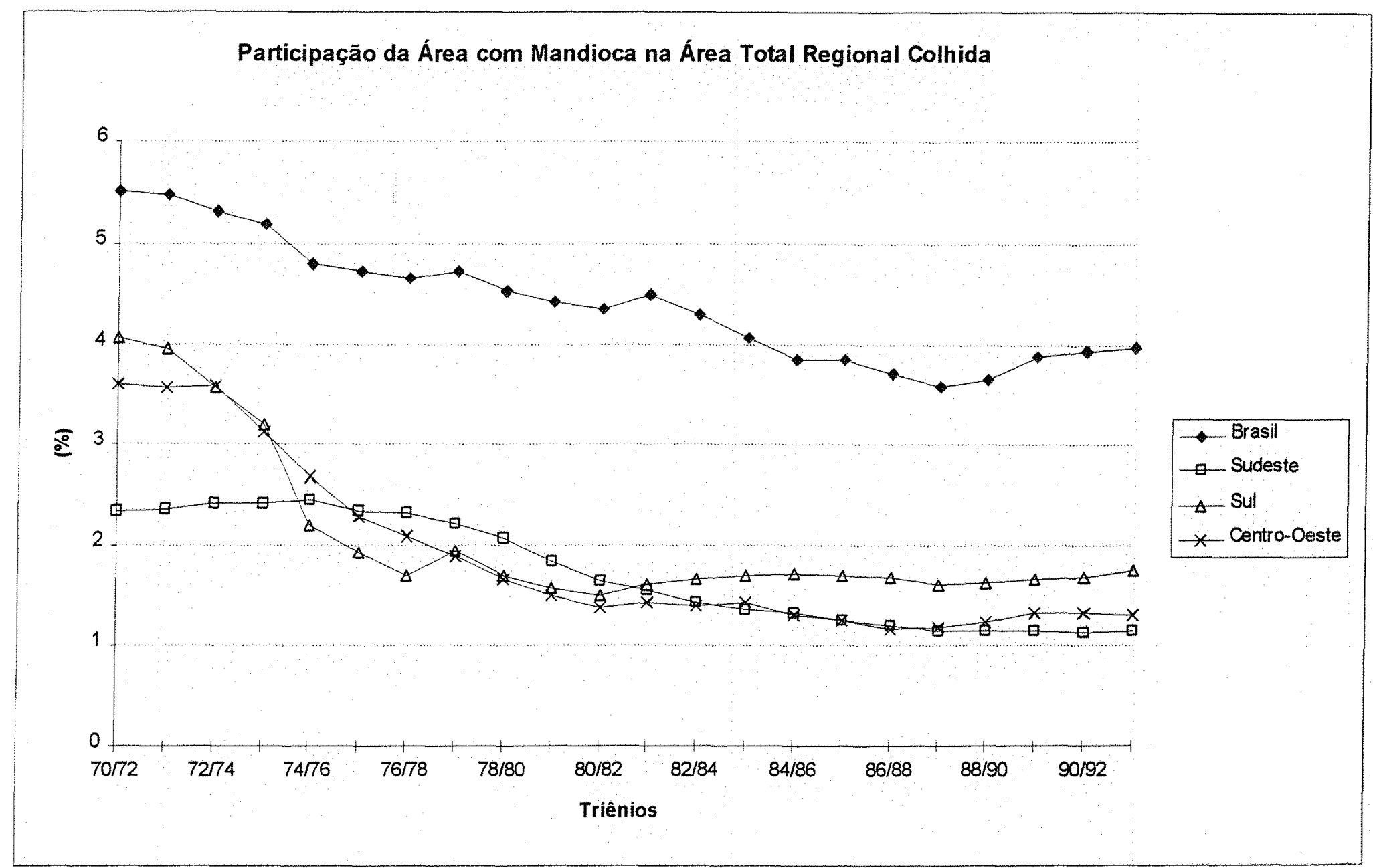

Fonte: Dados básicos - MARTIN \& GONÇALVES (1995)

Figura 08 - Participação da área colhida com mandioca na área total regional: Brasil, Sudeste, Sul e Centro-Oeste, $70 / 72$ a $90 / 92$ 
cana-de-açúcar, soja e laranja (nesta ordem). IGREJA \& CAMARGO (1992, p.141), analisando periodo mais recente (1979/81 a 1987/89) para o mesmo Estado, chegaram a resultados que indicam que a produção dessa cultura só não foi reduzida por ter havido ganhos de rendimento, pois o efeito-substituição foi de $-1,74 \%$ a.a.. Para o Estado de Goiás, no periodo 1975/84, YOKOYAMA (1988) encontrou resultados que apontam na mesma direção, ou seja, de substituição de área. Os valores apresentados pelo autor são respectivamente, $-9,60$ e 4,09\% a.a. (efeito-substituição e efeito-área).

Analisando-se as mudanças estruturais com ênfase nos estratos de área total, observa-se que no subperiodo $1970 / 75$ o processo de substituição foi bastante intensificado (Tabela 16). No subperido $1975 / 80$ a situação repetiu-se, embora com menor intensidade e uma exceção ocorrida no estrato de 2 a menos de 5 hectares. Já no subperiodo seguinte (1980/85) o efeito-área total indica que houve, além da incorporação de novas áreas à produção (efeito-escala positivo), a substituição de outras culturas pela mandioca. Em outras palavras, a expansão da área com essa cultura foi em grande parte decorrente da cessão de áreas pelas demais culturas. Curiosamente, nesse mesmo subperíodo uma das atividades que mais cedeu área foi a pastagem natural (IREC $=-84,32 \%$ ), (ver Tabela A2 do Apendice). Isto significa que provavelmente a cultura tenha apresentado incremento de área apenas em função do processo de formação de pastagem. Aliás, prática comum em todo o Brasil A análise anterior, também é válida para o subperiodo $1975 / 85$

Na Tabela 17, estão apresentados os indices de reestruturação de cultivo (IREC) da cultura da mandioca para os diferentes estratos de área. Contrariando o esperado, observa-se que há uma tendência para que esse indice seja de uma maior magnitude nos estratos menores - subperiodos $1970 / 75$ e 1975/80. Isso reflete o grau do impacto do processo de substituição de culturas, experimentado pela mandioca naqueles 
periodos. Por exemplo, do total de área disputada no estrato menor que 2 ha, a cultura cedeu $33,78 \%$. Isto que dizer que em relação à mandioca, o processo de substituição, de um modo geral, foi mais perverso nos pequenos estabelecimentos.

Tabela 16 - Efeito área total da cultura da mandioca decomposto em efeito escala e efeito substituição, 1970/75, 1975/80, 1980/85 e 1975/85, Brasil.

\begin{tabular}{|c|c|c|c|c|}
\hline Períodos & $\begin{array}{c}\text { Estratos } \\
\text { (ha) }\end{array}$ & $\begin{array}{c}\text { Efeito } \\
\text { Escala (\%) }\end{array}$ & $\begin{array}{c}\text { Efeito } \\
\text { Substituiçăo (\%) }\end{array}$ & $\begin{array}{c}\text { Efeito Área } \\
\text { Total (\%) }\end{array}$ \\
\hline $1970 / 75$ & $\begin{array}{l}<2 \\
2 \mathrm{a}-\text { de } 5 \\
5 \mathrm{a}-\mathrm{de} 10 \\
10 \mathrm{a}-\mathrm{de} 20 \\
20 \mathrm{a}-\mathrm{de} 50 \\
50 \mathrm{a}-\mathrm{de} 100 \\
100 \mathrm{a}-\mathrm{de} 500 \\
>500\end{array}$ & $\begin{array}{l}7,08 \\
-1,50 \\
-1,52 \\
-0,61 \\
0,64 \\
1,75 \\
2,04 \\
1,65\end{array}$ & $\begin{array}{l}-11,80 \\
-3,37 \\
-3,66 \\
-5,05 \\
-6,24 \\
-7,16 \\
-7,49 \\
-7,35\end{array}$ & $\begin{array}{l}-4,73 \\
-4,87 \\
-5,18 \\
-5,66 \\
-5,60 \\
-5,41 \\
-5,45 \\
-5,71\end{array}$ \\
\hline \multicolumn{2}{|c|}{ Variacão total no período } & 1,97 & $-7,29$ & $-5,32$ \\
\hline $1975 / 80$ & 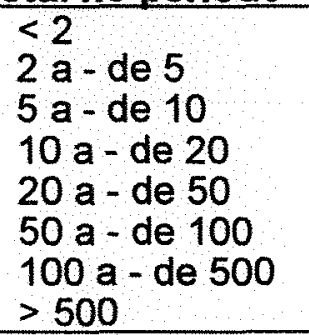 & $\begin{array}{l}-1,76 \\
-2,79 \\
-1,37 \\
-0,20 \\
0,37 \\
1,28 \\
7,05 \\
-1,04\end{array}$ & $\begin{array}{r}-0,70 \\
0,36 \\
-0,97 \\
-2,05 \\
-2,65 \\
-3,57 \\
-9,28 \\
-1,00\end{array}$ & $\begin{array}{l}-2,45 \\
-2,43 \\
-2,34 \\
-2,24 \\
-2,28 \\
-2,29 \\
-2,23 \\
-2,04\end{array}$ \\
\hline \multicolumn{2}{|c|}{ Variacão total no período } & 1,34 & $-3,66$ & $-2,32$ \\
\hline $1980 / 85$ & $\begin{array}{l}<2 \\
2 \mathrm{a} \text {-de } 5 \\
5 \mathrm{a} \text {-de } 10 \\
10 \mathrm{a} \text {-de } 20 \\
20 \mathrm{a} \text {-de } 50 \\
50 \mathrm{a} \text {-de } 100 \\
100 \mathrm{a} \text {-de } 500 \\
>500\end{array}$ & $\begin{array}{l}7,21 \\
11,75 \\
3,60 \\
2,01 \\
1,65 \\
1,25 \\
0,61 \\
0,11\end{array}$ & $\begin{array}{r}0,55 \\
-3,65 \\
4,40 \\
6,00 \\
6,27 \\
6,32 \\
6,80 \\
7,00\end{array}$ & $\begin{array}{l}7,77 \\
8,10 \\
8,00 \\
8,00 \\
7,92 \\
7,57 \\
7,41 \\
7,11\end{array}$ \\
\hline Variacão & total no periodo & 0,90 & 6,94 & 7,84 \\
\hline $1975 / 85$ & $\begin{array}{l}<2 \\
2 \text { a - de } 5 \\
5 \text { a - de } 10 \\
10 \text { a-de } 20 \\
20 \text { a-de } 50 \\
50 \text { a - de } 100 \\
100 \text { a-de } 500 \\
>500\end{array}$ & $\begin{array}{l}14,57 \\
6,97 \\
1,09 \\
0,84 \\
0,97 \\
0,75 \\
0,37 \\
0,16 \\
\end{array}$ & $\begin{array}{c}-11,99 \\
-4,29 \\
1,44 \\
1,57 \\
1,46 \\
1,57 \\
1,83 \\
1,72 \\
\end{array}$ & $\begin{array}{l}2,58 \\
2,67 \\
2,53 \\
2,41 \\
2,43 \\
2,31 \\
2,20 \\
1,88 \\
\end{array}$ \\
\hline Variação & total no período & 1,13 & 1,31 & 2,44 \\
\hline
\end{tabular}

Fonte: Dados básicos - Censo Agropecuário, IBGE, 1970, 1975, 1980 e 1985. 
Tabela 17 - Indice de reestruturação de cultivo da cultura da mandioca, nos periodos 1970/75, 1975/80, 1980/85 e 1975/85, Brasil.

\begin{tabular}{lrrrr}
\hline \multicolumn{1}{c}{$\begin{array}{c}\text { Estratos } \\
\text { (ha) }\end{array}$} & \multicolumn{4}{c}{ Indice de reestruturação de cultivo (IREC) } \\
\cline { 2 - 6 } & $1970 / 75$ & $1975 / 80$ & $1980 / 85$ & $1975 / 85$ \\
\hline 2 & $-33,78$ & $-27,10$ & 3,90 & $-17,69$ \\
2 a - de 5 & $-13,10$ & 2,35 & $-7,87$ & $-4,51$ \\
5 a - de 10 & $-13,42$ & $-2,59$ & 11,45 & 3,99 \\
10 a - de 20 & $-18,11$ & $-2,95$ & 14,67 & 4,04 \\
20 a - de 50 & $-16,31$ & $-2,38$ & 10,36 & 2,14 \\
50 a - de 100 & $-6,85$ & $-0,91$ & 5,80 & 1,41 \\
100 a - de 500 & $-2,29$ & $-0,13$ & 2,15 & 0,69 \\
$>500$ & $-0,29$ & 0,02 & 0,31 & 0,15 \\
\hline Total & $-4,74$ & $-1,06$ & 2,51 & 0,46 \\
\hline
\end{tabular}

Fonte: Dados básicos - Censo Agropecuário, IBGE, 1970, 1975, 1980 e 1985.

Nos demais subperíodos, detectou-se que 0 indice praticamente inverteu 0 comportamento apresentado na década de 70 . As causas prováveis desse comportamento devem estar relacionadas ao processo de pecuarização comentado anteriormente. Note-se, que devido a inexistência de informações por estratos de área para outros anos, a presente análise só foi considerada até 1985. Portanto, uma conclusão definitiva sobre o assunto carece de dados mais recentes.

Ainda que não possa ser observado em todo o periodo analisado, pelo menos durante os anos 70, a disputa de áreas foi mais acirrada no Brasil como um todo. Por isso, os índices de reestruturação de cultivo são mais elevados. De qualquer forma, na fase de intensificação do processo de substituição, as culturas que mais incorporaram áreas foram: pastagem plantada, soja, café e arroz (ver Tabela A3 do Apêndice). Isso se deveu à combinação de estímulos proporcionados pelo mercado e pelos incentivos 
diferenciados nas políticas de preço, de crédito e de geração de tecnologia. Por exemplo, a cultura da soja além de ser beneficiada pelos resultados favoráveis da pesquisa agronômica, reagiu adequadamente aos subsidios aos insumos modernos e ao programa especial de ocupação do cerrado brasileiro. Naquela época o café ainda desfrutava das benesses proporcionadas pelo Estado. E, é a partir do meados da década de 70 que aparecem os resultados do plano de renovação dos cafezais iniciados nos anos $69 / 70$. No caso das pastagem plantada, a tendência de crescimento foi motivada pela política de crédito abundante e subsidiado que prevaleceu no período.

\subsection{As Políticas públicas e o Desempenho da Cultura da Mandioca: uma VISÃo GERAL}

Os resultados apresentados nesta seção estão baseados nos estudos empiricos realizados com os modelos I e II descritos anteriormente. Apesar de terem sido testadas estimativas com as variáveis na escala aritmética, a forma funcional de estimação dos modelos que melhor se ajustou ao fenômeno estudado, foi a forma linear nos logaritmos das variáveis(11). Diante disto, os parâmetros estimados podem ser diretamente considerados como estimativas das elasticidades. Convém salientar que com o objetivo de captar a tendência da produção de mandioca, a variável $T$ foi incluida nos modelos durante os testes empiricos.

\subsubsection{Testando a existência de correlação contemporânea}

Considere o modelo genérico de um conjunto de equações lineares múltiplas, do tipo:

(11) A variável T foi considerada na escala aritmética. 


$$
y_{i}=X_{i} \beta_{i}+e_{i} \quad i=1,2, \ldots, M
$$

Dado que $e_{i t}$ é o erro da i-ésima equação no tempo t-ésimo, a suposição de correlação contemporânea, mas não de correlação ao longo do tempo, isto é, em diferentes períodos, implica que $\mathrm{E}\left[\mathrm{e}_{\mathrm{it}} \mathrm{e}_{\mathrm{js}}\right]=\sigma_{\mathrm{ij}}$ se $\mathrm{t}=\mathrm{s}$, e 0 (zero) se $\mathrm{t} \neq \mathrm{s}$. $O$ teste estatístico para a identificação da correlação contemporânea, considera as seguintes hipóteses (JUDGE, et alii 1988):

$$
\begin{aligned}
& H_{0}=\text { todas as covariâncias }\left(\sigma_{i j}\right) \text { são iguais a }(0) \text { zero. } \\
& H_{A}=\text { pelos menos uma covariância }\left(\sigma_{i j}\right) \text { não é igual a }(0) \text { zero. }
\end{aligned}
$$

No caso geral de M equações e T observações, a estatística é dada por:

$$
\lambda=T \sum_{i=2 j}^{M} \sum_{j=1}^{i} r_{i j}^{2}
$$

onde $\lambda$ tem distribuição $\chi^{2}$ com M(M-1)/2 graus de liberdade e o quadrado da correlação é dado por: $\mathbf{r}_{\mathbf{i j}}^{2}=\frac{\hat{\sigma}_{\mathbf{i j}}^{2}}{\hat{\sigma}_{\mathbf{i i}} \hat{\sigma}_{\mathbf{j j}}}$.

Nas Tabelas A4 e A5 (Apêndice), encontram-se, respectivamente, os valores estimados das covariâncias dos erros das equações componentes dos modelos I e II. Com base nesses valores calculou-se a estatística $\lambda$ referente aos dois modelos (Tabela 18).

Os resultados apresentados na Tabela 18 , mostra que em ambos os modelos, o valor crítico é maior que o valor calculado, não se rejeitando a hipótese nula. Pode-se, então, concluir que o erro de uma dada equação não está correlacionado com o erro de outra equação. Neste sentido, as equações referentes aos diferentes Estados podem ser estimadas independentemente, ou usando-se um processo que combine dados em cross-section com dados de séries temporais. 
Tabela 18 - Resultados dos testes para a verificação da existência de correlação contemporânea, nos modelos I e II.

\begin{tabular}{lcc}
\hline \multicolumn{1}{c}{ Especificações } & Modelo I & Modelo II \\
\hline Estatística $\lambda$ & 0,0004 & 0,0061 \\
Graus de liberdade & 3 & 6 \\
Valor crítico da distribuição $\chi^{2}$ a $5 \%$ & 7,81 & 12,59 \\
\hline
\end{tabular}

Fonte: Dados da pesquisa

\subsubsection{Modelo I}

No caso especifico do modelo I, em função das dificuldades de acesso a algumas informações, tais como pluviosidade média registrada nas principais regiōes produtoras de mandioca no Estado do Maranhão, optou-se por estimativas independente para os diferentes Estados.

\section{a) Estado do Pará}

Os resultados obtidos estão dispostos na Tabela 19. A matriz de correlação linear simples (Tabela A6 - Apêndice), fornece indicações de um grau relativamente elevado de colinearidade entre os pares das seguintes variáveis predeterminadas: CMDOR e $\mathrm{PROD}_{\mathrm{t}-1}, C M D O R$ e $T$ e, $P R O D_{t-1}$ e T. Todavia, os coeficientes de correlação lineares são de magnitude inferior ao coeficiente de determinação múltipla da regressão, sendo assim um indicativo da pouca relevância do problema (JUDGE, et alii 1988). 
Tabela 19 - Resultados do ajustamento da equação referente ao Estado do Pará (modelo I).

\begin{tabular}{|c|c|c|c|}
\hline $\begin{array}{l}\text { Variáveis } \\
\text { Explicativas }\end{array}$ & $\begin{array}{c}\text { Coeficientes de } \\
\text { Regressão } \\
\end{array}$ & $\begin{array}{c}\text { Teste de " } t \text { " } \\
\text { Student } \\
\end{array}$ & Desvios-Padrão \\
\hline Pmín $_{t-2}$ & $-0,330^{*}$ & $-2,951$ & 0,111 \\
\hline PMERC $_{t-2}$ & 0,088 & 1,195 & 0,073 \\
\hline CMDOR & 0,041 & 0,565 & 0,073 \\
\hline REND & $0,825^{\star \star}$ & 2,187 & 0,377 \\
\hline CRDRUR $_{\mathrm{t}-2}$ & 0,002 & 0,173 & 0,012 \\
\hline $\mathrm{PROD}_{\mathrm{t}-1}$ & 0,057 & 0,250 & 0,230 \\
\hline $\mathrm{T}$ & $0,059^{*}$ & 3,802 & 0,015 \\
\hline \multicolumn{3}{|c|}{ - Coeficiente de determinação múltipla $\left(R^{2}\right)=$} & 0,981 \\
\hline \multicolumn{3}{|c|}{ Valor da estatistica $F(7,12)$} & 88,281 \\
\hline
\end{tabular}

Fonte: Dados da pesquisa

- Níveis de significância:

$\left.{ }^{*}\right)$ e $\left.{ }^{* *}\right) 1 \%$ e $5 \%$ de probabilidade respectivamente.

O coeficiente de determinação múltipla $\left(R^{2}=0,981\right)$ mostra que $98,1 \%$ das variações ocorridas na variável endógena são explicadas pelas variáveis predeterminadas. A estatistica $F$, com valor de 88,281 , mostra-se estatisticamente significativa a $1 \%$ de probabilidade. Estes resultados, indicam que o modelo ajusta-se a fenômeno estudado (Tabela 19).

A presença de autocorrelação nos resíduos em modelos com a variável endógena defasada como variável independente, é geralmente identificada pelo teste 
estatístico $\mathrm{h}$ proposto por Durbin. Dada a construção desse teste, isso só será possivel se a restrição $\hat{\mathrm{V}}(\mathrm{b})<(12)$ for satisfeita. Caso contrário, o autor sugere alternativamente o uso de um teste equivalente, isto é, uma regressão estimada por mínimos quadrados, dos resíduos $\hat{e}_{t}$ contra $\hat{e}_{t-1} e$ as demais variáveis independentes, inclusive a variável defasada. $O$ teste de significância do coeficiente $\hat{e}_{t-1}$ usado no procedimento padrão de mínimos quadrados será o indicador de correlação serial (JUDGE, et alii 1988). Para este caso (Estado do Pará), com 10 graus de liberdade a estatística $t$ igual a $-0,935$ referente a $\hat{e}_{t-1}$, indica que estatisticamente o parâmetro não é significativo, sugerindo ausência de correlação serial de primeira ordem.

Exceto os sinais dos coeficientes associados às variáveis $\mathrm{Pmin}_{\mathrm{t}-2}$ (preço minimo) e CMDOR (custo de mão-de-obra rural), os demais sinais apresentam consistência com a teoria económica. No caso desta última variável o parâmetro estimado não foi estatisticamente significativo (Tabela 19).

A contradição econômica identificada no sinal do parâmetro da variável Pmint-2 também pode ser interpretada como uma indicação da falta de confiança dos produtores do Estado do Pará na PGPM, uma vez que, neste caso, incrementos nos preços mínimos pode levar a uma redução na produção de mandioca. Isso pode ser justificado pelo fato da política de preços ser regionalizada e, os produtores de outros estados - que confiam na politica - responderem positivamente à PGPM e, conseqüentemente aumentarem a exportação do produto para o Estado do Pará. Este comportamento provavelmente fez parte da estratégia de redução de riscos adotado pelos produtores deste Estado. Conclui-se portanto, que neste Estado a PGPM afetou a produção de mandioca no sentido contrário ao esperado.

(12) Onde T é o número de observações e $\hat{V}(b)$ representa a estimativa da variância associada ao coeficiente da variável defasada (JUDGE et alii, 1988). 
Com relação aos demais indicadores de politica agricola, observa-se na Tabela 19, que apenas o parâmetro associado à variável (REND) usada como proxy para captar os efeitos da política de mudança tecnológica, mostrou-se estatisticamente significativo. O comportamento do coeficiente da variável CRDRUR $\mathrm{R}_{\mathrm{t}-2}$, sugere que apesar da política de crédito rural estar positivamente associada à produção de mandioca no Estado, o seu efeito foi estatisticamente não significativo.

\section{b) Estado do Maranhão}

Os resultados do ajustamento da equação referente ao Estado do Maranhão são apresentados nas Tabelas 20 e A7 (Apêndice). Não há indicações de uma alta associação entre as variáveis predeterminadas, exceto no caso das variáveis $P R O D_{t-1}$ e T (Tabela A8 - Apêndice).

A presença de autocorrelação nos residuos foi avaliada por meio do teste alternativo proposto por Durbin descrito anteriormente. Com 11 graus de liberdade, a estatistica t referente a $\hat{e}_{\mathrm{t}-1}$ foi igual a 2,268 . Isto recomenda que se proceda a correção do problema de correlação serial detectado. Isso foi feito com o uso do método interativo desenvolvido por Cochrane-Orcutt e apresentado em KMENTA (1990).

Os resultados do ajustamento após a correção dos problemas de autocorrelação estão na Tabela 20 . $O$ valor da estatística $F$ da análise de variância da equação ajustada $(7,101)$ foi significativo a $1 \%$ de probabilidade. $O$ coeficiente de determinação múltipla de 0,819 implica que as variações observadas na variável endógena podem ser em $81,9 \%$ dos casos, explicadas pelo efeito combinado das variáveis exógenas. 
Tabela 20 - Resultados do ajustamento da equação referente ao Estado do Maranhão (modelo I), após a correção dos problemas de correlação serial.

\begin{tabular}{|c|c|c|c|}
\hline $\begin{array}{c}\text { Variáveis } \\
\text { Explicativas }\end{array}$ & $\begin{array}{c}\text { Coeficientes de } \\
\text { Regressão } \\
\end{array}$ & $\begin{array}{l}\text { Teste de " } \mathrm{t} " \\
\text { Student } \\
\end{array}$ & Desvios-Padrão \\
\hline $\mathrm{Pmin}_{t-2}$ & $-0,823^{*}$ & $-4,618$ & 0,178 \\
\hline PMERC $_{t-2}$ & $0,256^{\star \star *}$ & 1,735 & 0,148 \\
\hline CMDOR & 0,058 & 0,615 & 0,094 \\
\hline REND & $1,665^{\star}$ & 4,853 & 0,343 \\
\hline CRDRUR $_{\mathrm{t}-2}$ & $0,024^{* * *}$ & 1,529 & 0,015 \\
\hline $\operatorname{PROD}_{t-1}^{*}(1)$ & $0,237^{\star \star \star}$ & 2,027 & 0,117 \\
\hline \multirow[t]{3}{*}{$T$} & $-0,002$ & 0,881 & $-0,153$ \\
\hline & \multicolumn{2}{|c|}{ - Coeficiente de determinação múltipla $\left(R^{2}\right)$} & 0,819 \\
\hline & da estatistica $\mathrm{F}(7$, & $=$ & 7,101 \\
\hline
\end{tabular}

Fonte: Dados da pesquisa.

(1) $P R O D_{t-1}^{2}$, variável instrumental para $P R O D_{t-1}$, conforme sugerido por Wallis, e apresentado em HOFFMANN $(1987$, p. 274).

- Niveis de significancia:

$\left(^{*}\right)$ e $\left(^{* *}\right) 1 \%$ e $5 \%$ de probabilidade respectivamente.

$\left.{ }^{\star * \star \star}\right) 10 \%$ de probabilidade (unilateral).

Ainda na Tabela 20 , observa-se que os sinais dos coeficientes das variáveis

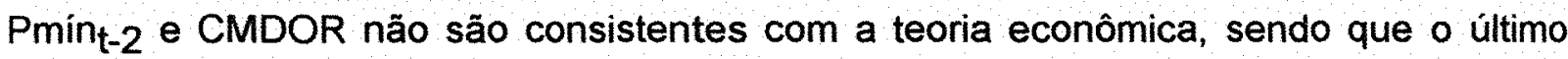
coeficiente é estatisticamente não significativo. No tocante ao comportamento do parâmetro da variável $\mathrm{Pmin}_{\mathrm{t}-2}$, as considerações efetuadas para o Estado do Pará são válidas para este Estado. Quanto aos demais indicadores de política (REND e CRDRUR $_{t-2}$ ) observou-se a relação esperada $e, 0$ fato de serem estatisticamente 
significativos, indica que as referidas politicas foram importantes para explicar o comportamento da produção de mandioca no Estado. Contudo, o pequeno valor da elasticidade-crédito da produção de mandioca (coeficiente da variável CRDRUR $\mathrm{t}_{\mathrm{t}-2}$ ) mostra a pouca relevância da política de crédito nesse Estado.

\section{c) Estado da Bahia}

Nas Tabelas 21 e A9 (Apêndice) são apresentados os resultados da equação estimada para o Estado da Bahia. Os níveis de correlação entre as variáveis explanatórias não fornece indicação de uma alta colinearidade entre estas variáveis (Tabela A10 - Apêndice). O valor encontrado para a estatística $h(13)$ atesta a presença de correlação serial nos resíduos (Tabela A9). Para a correção dos problemas de autocorrelação, também utilizou-se o método desenvolvido por Cochrane-Orcutt.

Na Tabela 21 pode-se observar os resultados do ajustamento da equação após resolvidos os problemas de autocorrelação. $O$ coeficiente de determinação da regressão ajustada é estatisticamente diferente de zero ao nivel de significância de $1 \%$, indicando que $96,3 \%$ da variação amostral da produção de mandioca pode ser atribuida ao efeito das variações nas variáveis independentes. Apesar da regressão ter apresentado um ajustamento razoável, os sinais da maioria dos parâmetros estimados apresentaram sinais contrário ao esperado $\left(\right.$ Pmin $_{\mathrm{t}-2}$, PMERC $_{\mathrm{t}-2}$, CMDOR e PLUV). Para explicar a contradição econômica observada com o sinal do coeficiente da variável Pmínt-2, podese considerar os mesmos argumentos usados para os Estados do Pará e do Maranhão (14). Os sinais dos coeficientes de regressão das outras variáveis indicadoras

(13) Valor crítico de 2,35 a $1 \%$ de probabilidade

(14) As explicações para o comportamento dos coeficientes das demais variáveis que foram estatisticamente significativas serão dadas no item 5.4.4. 
de politica (REND e CRDRURt-2) estão todos consistentes com a teoria econômica, mostrando que uma melhora na política de mudança tecnológica e um aumento na oferta de crédito rural, tudo mais constante, tende a incrementar a produção de mandioca.

Tabela 21 - Resultados do ajustamento da equação referente ao Estado da Bahia (modelo I), após a correção dos problemas de correlação serial.

\begin{tabular}{|c|c|c|c|}
\hline $\begin{array}{l}\text { Variáveis } \\
\text { Explicativas }\end{array}$ & $\begin{array}{c}\text { Coeficientes de } \\
\text { Regressão }\end{array}$ & $\begin{array}{c}\text { Teste de " } t \text { " } \\
\text { Student } \\
\end{array}$ & Desvios-Padrão \\
\hline Pmint-2 & $-0,279^{\star \star}$ & $-3,417$ & 0,082 \\
\hline PMERC $_{t-2}$ & $-0,991^{\star \star}$ & $-3,283$ & 0,030 \\
\hline PLUV $_{\mathrm{t}-3}$ & $0,040^{\star \star \star}$ & 1,415 & 0,028 \\
\hline CMDOR & $0,167^{\star \star}$ & 2,497 & 0,067 \\
\hline REND & $0,758^{\star \star}$ & 3,357 & 0,226 \\
\hline PLUV & $-0,023$ & $-0,697$ & 0,033 \\
\hline CRDRUR $_{t-2}$ & $0,071^{*}$ & 7,244 & 0,010 \\
\hline $\mathrm{PROD}_{t-1}^{*}(1)$ & 0,026 & 0,125 & 0,205 \\
\hline $\mathrm{T}$ & $-0,006$ & $-0,585$ & 0,010 \\
\hline \multicolumn{3}{|c|}{ - Coeficiente de determinação múltipla $\left(R^{2}\right)=$} & 0,963 \\
\hline \multicolumn{3}{|c|}{ - Valor da estatística $F(9,10)$} & 20,185 \\
\hline
\end{tabular}

Fonte: Dados da pesquisa

(1) $P R O D_{t-1}$, variável instrumental para $P R O D_{t-1}$, conforme sugerido por Wallis, e apresentado em HOFFMANN (1987, p. 274).

- Níveis de significância:

$\left({ }^{*}\right)$ e $\left(^{\star *}\right) 1 \%$ e $5 \%$ de probabilidade respectivamente.

(***) $10 \%$ de probabilidade (unilateral). 
A variável $\left(\right.$ PLUV $\left._{\mathrm{t}-3}\right)$ usada como proxy para captar os efeitos da disponibilidade de manivas-sementes para o plantio, apresentou os resultados esperados, confirmando assim, a importância deste insumo para o processo produtivo da cultura no Estado da Bahia.

\subsubsection{Modelo II}

Na proposta inicial considerou-se que as variáveis Pmín, PMERC, PFNORD e CRDRUR seriam defasadas em dois anos (t-2), entretanto, considerando-se as sugestões de alguns técnicos $(15)$ envolvidos com a cultura, estimativas preliminares foram efetuadas com as variáveis defasadas em $t-1$. Essas estimativas apresentaram um ajustamento melhor, confirmando, portanto, as hipóteses levantadas peios técnicos e justificando a sua adoção nesse estudo.

Constatada a ausência de correlação contemporânea (Tabela 18) e dispondo-se das informações necessárias, foi possivel estimar os parâmetros do modelo II, combinando-se dados em cross-section com os dados de séries temporais. De acordo com a aplicação empirica do modelo de covariância é necessário investigar a pertinência da inclusão das variáveis binárias no modelo proposto. Esse procedimento foi realizado por meio de um teste de $F$, definido na seção 4.3 .1 , e os resultados encontram-se na Tabela 22 .

Os dados apresentados na Tabela 22 permite rejeitar a hipótese de que todas as equações ajustadas possuem o mesmo intercepto e, conclui-se que todas as funções estimadas para os Estados não possuem o mesmo intercepto, logo é pertinente a

$\left(^{15}\right)$ Técnicos do Centro Nacional de Pesquisa de Mandioca e Fruticultura Tropical - EMBRAPA, levantaram a hipótese de que em função da redução do ciclo da cultura na Região Centro-Sul, a defasagem entre o plantio e a colheita do produto deveria ser reduzida. 
inclusão das variáveis binárias (modelo de covariância). Os resultados da equação ajustada considerando-se esse modelo estão apresentados na Tabela A12 (Apêndice) e, a matriz de correlação simples na Tabela A13. Essa matriz não apresenta sinais de alta associação entre as variáveis exógenas (exceto IPPC e T e CMDOR e T), sugerindo um grau de multicolinearidade aceitável.

Tabela 22 - Resultados do teste estatístico usado para comparação dos modelos.

Especificações
Modelo sem as

variáveis binárias

Modelo de covariância

\begin{tabular}{rcc}
\hline Soma dos quadrados dos residuos & 1,570 & 1,257 \\
Graus de liberdade & 3 & 75 \\
Valor da Estatística & $F(3,75)=$ & 6,22 \\
\hline
\end{tabular}

Fonte: Dados básicos, Tabelas A11 e A12.

Quando se trabalha com dados em cross-section e com dados de séries temporais é razoável pressupor a existência de heterocedasticia e autocorrelação nos residuos. Visando corrigir estes problemas utilizou-se os procedimentos propostos por KMENTA (1990). Salienta-se que neste estudo assumiu-se que o coeficiente de autocorrelação $(\rho)$ tem o mesmo valor para todas as unidades cross-section (estados) (KMENTA, 1990 e JUDGE et alii, 1988).

Nas Tabelas 23 e A14 apresentam-se os resultados das estimativas após removidos os problemas de autocorrelação e heterocedasticia. Como o processo para correção da heterocedasticia não levou a melhoras nas estimativas dos parâmetros, a 
análise foi efetuada apenas na equação ajustada sem os problemas de autocorrelação nos residuos (Tabela 23).

Tabela 23 - Resultados do ajustamento da equação estimada pelo processo chamado de pooling (modelo II), considerando-se o modelo de covariância, com as devidas correções dos problemas de autocorrelação dos resíduos (Estados de Minas Gerais, São Paulo, Paraná e Rio Grande do Sul).

\begin{tabular}{|c|c|c|c|}
\hline $\begin{array}{c}\text { Variáveis } \\
\text { Explicativas(1) }\end{array}$ & $\begin{array}{c}\text { Coeficientes de } \\
\text { Regressão } \\
\end{array}$ & $\begin{array}{c}\text { Teste de " } \mathrm{t} \text { " } \\
\text { Student } \\
\end{array}$ & Desvios-Padrão \\
\hline $\mathrm{Pmin}^{*}{ }_{\mathrm{t}-1}$ & 0,017 & 0,165 & 0,100 \\
\hline PMERC $^{*}-1$ & 0,022 & 0,590 & 0,037 \\
\hline IPPC $^{*}$ & $-0,039$ & $-0,403$ & 0,098 \\
\hline CMDOR* $^{*}$ & 0,103 & 1,271 & 0,081 \\
\hline REND* & $0,734^{*}$ & 3,935 & 0,187 \\
\hline PFNORD $^{*} t-1$ & 0,019 & 0,413 & 0,047 \\
\hline CRDRUR $^{\star} \mathrm{t}-1$ & $0,024^{\star * *}$ & 1,895 & 0,013 \\
\hline $\mathrm{PROD}^{*}{ }_{\mathrm{t}-1}$ & $0,074^{*}$ & 10,550 & 0,073 \\
\hline$T^{*}$ & 0,008 & 0,878 & 0,009 \\
\hline$-v$ & da estatística F (13 & $=$ & $72.663,764$ \\
\hline
\end{tabular}

Fonte: Dados da pesquisa.

(1) O asterisco (*) nas variáveis indica que as estimativas foram efetuadas com as devidas correção para autocorrelação nos resíduos.

- Niveis de significância:

$\left(^{*}\right)$ e $\left(^{* *}\right) 1 \%$ e $5 \%$ de probabilidade respectivamente.

$\left.{ }^{(\star \star \star}\right) 10 \%$ de probabilidade (unilateral). 
A estatística $F$ evidencia que o modelo ajusta-se ao fenômeno estudado. A exceção da variável CMDOR, todos os sinais das demais variáveis independentes estão de acordo com a teoria econômica.

A variável $\left(P_{\min }\right)$ que tenta captar os efeitos da política de preço mínimo, apesar de mostrar uma relação positiva entre esta politica e a produção de mandioca, não foi estatisticamente significativa. Este fato demonstra a ineficiência da PGPM para os produtores de mandioca da Região Centro-Sul As variáveis REND e CRDRUR $\mathrm{t}_{\mathrm{t}-1}$. foram estatisticamente significativas. Por outro lado, a magnitude da elasticidade-crédito da produção confirma as suposiçōes de pouco impacto da política de crédito rural para o produto.

Para quantificar os efeitos da política de incentivo diferenciado, foi incluido no modelo um indice de preço dos produtos "concorrentes" (IPPC). Esse indice contempla, além dos preços, as mudanças nas áreas colhidas e nos rendimentos dos produtos (trigo, milho e soja). A correlação negativa entre a produção de mandioca e o IPPC, indica que variações no índice, proporciona mudanças na produção de mandioca no sentido contrário. Todavia, o comportamento estatístico do coeficiente da variável IPPC, sugere que tudo mais constante, a produção de mandioca na Região Centro-Sul pode não depender do comportamento dos produtos considerados na construção do indice. Mas, isso não exclui a possibilidade do comportamento desses produtos influenciarem o setor como um elemento complementar no processo de substituição de culturas.

Analisando-se o coeficiente da variável $P F N O R D_{t-1}$ confirma-se a relação positiva entre a produção de mandioca na Regiões Centro-Sul e o preço dos seus derivados no Nordeste. O processo funciona da seguinte forma: quedas de safra na Região Nordeste, implica em aumento dos preços dos produtos derivados no mercado nordestino. Diante disto, os produtores, principalmente de farinha, da Região Centro-Sul 
são estimulados. Contrariando as expectativas iniciais, o coeficiente da variável não se apresentou estatisticamente significativa. Isto pode ser explicado pelo fato da variável dependente incorporar a produção agregada, ou por não existir nenhuma relação causal entre esta e o preço dos produtos. Outros trabalhos devem ser desenvolvidos visando esclarecer esta situação

\subsubsection{Outras consideraçōes}

A capacidade de resposta da produção agregada de mandioca em relação aos indicadores de politica agricola considerados neste estudo, foi na maioria dos casos positiva e estatisticamente significativa, excetuando os casos do crédito rural no Estado do Pará e, do preço minimo nos estados componentes do modelo I (Pará, Maranhão e Bahia) e no modelo II (pooling).

Para os Estados do Norte-Nordeste, o coeficiente de regressão associado a variável indicadora da política de preço mínimo (Pmín), apresentou invariavelmente sinal negativo e significância estatística. Esta constatação surpreendente contraria as hipóteses formuladas inicialmente. Além das explicações já apresentadas para este fato, adicionalmente pode-se argumentar que este comportamento é uma decorrência das peculiaridades de produção e comercialização da mandioca nas referidas regiōes. $\mathrm{Ou}$ seja, produto de origem familiar, de onde parcela substancial da produção é retida pelos agricultores.

Sobre este tema, KRISHNA (1977) revela que os valores das elasticidades-preço da área $(16)$ de cultivo de uma série de produtos estudados, dependem mais da posição que os produtos individualmente ocupam na economia das diferentes regióes e da (16) No presente estudo, deve-se considerar elasticidade-preço da produção e, não da área. 
disponibilidade de recursos e alternativas, do que de propensões intrínsecas dos agricultores face a flutuações de preços. As evidências empiricas encontradas neste estudo, estão de acordo com a argumentação deste autor, não só com relação à variável Pmin (preço mínimo), mas também no tocante à variável PMERC (preço de mercado), nas situações em que o sinal da mesma foi incorreto ou não significativo estatisticamente.

Portanto, os resultados até aqui alcançados oferecem indicativos de que a PGPM ou não foi eficiente para alterar a produção da cultura da mandioca ou influenciou a produção no sentido contrário ao esperado. FOX (1979) também chegou a resultados semelhantes com relação aos produtos algodão, arroz, milho e feijão. Este autor considerou, no periodo analisado, difícil atribuir ao programa de preço minimo parte do crescimento experimentado por essas culturas na Região Nordeste do Brasil.

Com relação à politica de crédito, observou-se que o Estado da Bahia foi o que apresentou o maior valor para a elasticiadade-crédito da produção $(0,071)$. Isto significa que seria necessário um incremento de $100 \%$ no volume de crédito para que a produção aumentasse em $7,1 \%$, sendo em valores absolutos $(17)$ equivalente a aproximadamente 213 mil toneladas. Já para os estados da Região Centro-Sul, o mesmo incremento no volume do crédito aplicado (100\%), proporcionaria na produção um aumento em torno de 36 mil toneladas, pois a elasticiadade-crédito da produção foi de 0,024 . Contudo, é necessário esclarecer que as elasticidades encontradas neste trabalho não devem ser estritamente comparáveis, uma vez que os procedimentos metodológicos usados nos modelos I e II, foram diferentes. Neste sentido, não se deve fazer inferencias comparativas entre os impactos das politicas nas Regiöes Centro-Sul e Norte-Nordeste.

(17) É necessário também considerar a capacidade de resposta em termos da produção total absoluta. Ver sobre o assunto KRISHNA (1977). 
Novamente, o rendimento físico por unidade de área como um indicador do processo de mudança tecnológica, deve ser tomado com cautela. Entretanto, os resultados empíricos deste estudo, apesar das limitações, estão sugerindo que um aumento de $10 \%$ no rendimento físico, implica em uma ampliação de $16,7 \%$ na produção de mandioca no Estado do Maranhão, onde a elasticidade-rendimento da produção foi a mais elevada.

Conforme já mencionado, em algumas das equações estimadas neste estudo, as variáveis PMERC e CMDOR - em todas as equações - ou apresentaram comportamento contrário ao esperado pela teoria econômica, ou não foram estatisticamente significativas. Como a variável dependente utilizada nas estimativas para captar a tomada de decisão dos produtores foi a produção e, não área plantada, isso pode ter levado a uma resposta um pouco viesada e, ter contribuído para que as variáveis apresentassem as relaçōes contraditórias observadas. De certa forma, isso também explica, em parte, os problemas identificados com a variável indicadora da política de preço minimo (Pmín).

Outro aspecto que deve ser considerado dentro deste contexto, refere-se à qualidade dos dados, principalmente com relação a série de preços de mercado (Tabelas A15 e A16). Nesta série foram identificados valores que estão muito acima da média histórica. Isso leva a crer que provavelmente deve ter ocorrido problemas no levantamento primário dos dados efetuados pela Fundação Getúlio Vargas (FGV), pois não há razões para o preço real apresentar flutuações tão grandes.

Com relação a variável $T$ (tendência), observa-se que ela foi estatisticamente significativa apenas para ao Estado do Pará indicando crescimento da produção. $O$ comportamento dessa variável nos demais estados revela a tendência de estagnação do setor nos últimos anos. 
No modelo I, a variável $\mathrm{PROD}_{\mathrm{t}-1}$ não foi estatisticamente significativa. Já para o modelo II, como ela foi estatisticamente significativa a $1 \%$ de probabilidade, indica um ajustamento não instantâneo. 


\section{CONSIDERAÇÕES FINAIS}

Tomando-se como base os estudos apresentados, os aspectos teóricos relativos às políticas públicas orientadas para o setor agricola e as evidências empiricas encontradas neste trabalho, relacionam-se as seguintes consideraçōes finais:

(1) A produção de mandioca está associada a pelo menos dois grupos de produtores, conforme caraterização apresentada na Tabela 4. Isso foi confirmado pelos coeficientes de determinação múltipla $\left(R^{2}\right)$ e as significâncias estatísticas obtidas no conjunto das regressões estimadas.

(2) Na década de 70 os preços mínimos de mandioca eram diferenciados por região. A exceção do ano de 1972, na Região Centro-Sul o preço apresentou-se superior, pelo menos até o ano de 1979. Com raras exceções, independentemente da região, no período estudado, os preços mínimos foram fixados muito abaixo dos preços de mercado (Tabelas A15 e A16). Esta evidência sugere que pode ter havido uma decisão governamental de não incentivar maiores produção.

Para os Estados do Norte-Nordeste, o coeficiente de regressão associado a variável indicadora da politica de preço mínimo (Pmín), apresentou invariavelmente sinal negativo e significância estatística. Esta constatação surpreendente contraria as hipóteses formuladas inicialmente. Argumenta-se que este comportamento é uma decorrência das peculiaridades de produção e comercialização da mandioca nas referidas regiões, ou seja, produto de origem familiar, onde parcela substancial da produção é retida pelos agricultores. Nesse caso pode-se aceitar uma relação 
negativa entre produção e preço. Para a Região Centro-Sul, apesar do coeficiente se mostrar consistente com a teoria econômica, não foi estatisticamente significativo.

Portanto, os resultados até aqui alcançados oferecem indicativos de que a PGPM não foi eficiente para incrementar a produção da cultura da mandioca.

(3) Há um consenso entre os estudiosos do assunto (politica de crédito rural) que o "subsidio" implicito gerou desequilibrio entre a oferta e a demanda de crédito rural. Essa situação levou a racionamento do crédito por parte dos agentes financeiros, que acabaram orientando os recursos para os produtos de maior rentabilidade e/ou produtores que oferecem maior reciprocidade. Conseqüentemente, houve desajustamentos nos mercados de produtos e fatores, gerando ineficiências tanto no uso dos recursos produtivos como na combinação dos produtos agropecuários.

(4) Como a cultura da mandioca é geralmente cultivada por pequenos produtores, isso implica que segundo as normas do crédito rural, eles deveriam ser beneficiados com taxas de juros preferenciais, com algum grau de subsídio implícito. Esse subsídio deve ter provocado como conseqüência, maior racionamento de crédito para a cultura da mandioca, uma vez que os produtores tiveram que enfrentar maiores restrições para ter acesso às linhas de crédito. Isso se reflete, na menor participação relativa no crédito rural para custeio, que alcançou apenas $0,39 \% \mathrm{em}$ 1990.

Essa situação pode ser, alternativamente, abordada pelo lado da demanda. Pode ter ocorrido uma menor demanda por crédito para a cultura da mandioca, levando-se em consideração que naquele periodo (a partir de 1977, Figura 02) os preços recebidos pelos produtores dessa cultura estavam em declínio e, isso não estimulou a assunção de maiores riscos. $\mathrm{Na}$ verdade, deve ter ocorrido uma convergência dos fatores, tanto do lado da oferta como da demanda. 
(5) No período de 1974 a 1983, que é considerado em geral como um periodo em que o crédito agrícola foi muito subsidiado no Brasil, observou-se que as fontes de crescimento da produção da mandioca não responderam positivamente aos incentivos proporcionado pelo crédito. Isso pode ter sido uma conseqüência dos efeitos negativos ("desvios" - substituição) de uma política de crédito subsidiado, que interagindo com outros fatores, resultaram em redução de área, produção e rendimento físico naquele período. Pelas razões consideradas anteriormente na seção 5.1.2., essa conclusão não deve ser tomada como definitiva.

(6) $\mathrm{Na}$ análise do perfil distributivo do crédito rural, observaram-se que houve uma tendência de concentração do crédito na década de 80 , comparativamente à de 70 , tanto no aspecto do comportamento agregado das culturas, como no caso especifico da cultura da mandioca em relação aos Estados (Tabelas 8 e 10). Essa constatação de piora no perfil distributivo do crédito de custeio agricola na década de 80, está de acordo com os resultados obtidos por GATTI et alii (1993). E, associado à redução da participação relativa da mandioca no volume total de crédito para custeio (Tabela 5), confirma a hipótese de uma deterioração da distribuição do crédito na última década. Isso é explicado, em parte, pelo menor volume de crédito aplicado no setor agrícola.

(7) Seguindo a tendência dos demais produtos, na década de 70 o volume de crédito rural para os produtores de mandioca foi mais concentrado nas Regióes Sudeste e Sul. Isso deve ter ocorrido porque essas regiōes naquele periodo já eram as responsáveis pelo segmento mais dinâmico da mandiocultura nacional. Nestas regiōes se instalaram as agroindústrias processadoras de farinha de raspa que por força de lei eram adicionadas à farinha de trigo.

(8) De certa forma, o estudo também constata uma relação positiva entre crédito rural e nível tecnológico. Os valores estimados para a redundância da distribuição do crédito em relação à produção foram menores do que em relação à 
área. Se as distribuições (de crédito e de produção) apresentam uma menor discrepância, dado que a variável área é a mesma, no ano considerado, então foi o rendimento físico (via melhor nivel tecnológico) que exerceu uma compensação, reduzindo assim o grau de concentração.

(9) Os testes empíricos realizados nesta pesquisa revelaram que o Estado da Bahia foi o que apresentou o maior valor para a elasticiadade-crédito da produção $(0,071)$. Isto significa que seria necessário um incremento de $100 \%$ no volume de crédito para que a produção aumentasse em $7,1 \%$, sendo em valores absolutos equivalente a aproximadamente 213 mil toneladas. Já para os estados da Região Centro-Sul, o mesmo incremento no volume do crédito aplicado $(100 \%)$, proporcionaria um aumento na produção em torno de 36 mil toneladas, pois a elasticiadade-crédito da produção foi de 0,024 . Contudo, é necessário esclarecer que as elasticidades encontradas neste trabalho não devem ser estritamente comparáveis, uma vez que os procedimentos metodológicos usados nos modelos l e II, foram diferentes. Neste sentido, não se deve fazer inferências comparativas entre os impactos das politicas nas Regiōes Centro-Sul e Norte-Nordeste.

(10) Em sintese, pode-se afirmar que o difícil acesso dos produtores de mandioca ao crédito rural, as distorções identificadas nesta politica e os preços recebidos pelos produtores desse produto, foram fatores que interagiram e tornaram essa politica de pouco impacto para a mandiocultura nacional. Isso de certa maneira contraria os objetivos formais da política de crédito rural. Mas, já era esperado.

(11) A fonte de crescimento mais importante para a cultura da mandioca foi a mudança na área, pois o rendimento físico por unidade de área, apesar de ter sofrido redução, apresentou-se bastante estável. Isto indica que ainda permanecem inalterados os padrões de crescimento tradicionais de incremento na produção, ou seja, houve pouca incorporação de tecnologias ao longo do tempo. Os resultados do modelo "shift-share", para os respectivos estratos de área, nos subperiodos 
estudados, também sugerem que a dinâmica do comportamento da produção de mandioca, de um modo geral, foi estabelecido pela amplitude do efeito-área. Isso acaba confirmando a hipótese de pouca relevância do rendimento físico por unidade de área como fonte de crescimento da cultura. As exceções existentes, podem ser explicadas pela magnitude do efeito localização geográfica.

(12) O comportamento do rendimento físico nos diferentes estratos de área total apresentou a seguinte característica: nos estratos extremos, de um modo geral, tende a diminuir e, nos estratos médios a tendência é para um melhor desempenho dessa variável. Isso pode ser explicado tanto pela associação entre disponibilidade de área e restrições agroambientais, como pelos aspectos relacionados aos objetivos da produção (recuperação de pastagem) e a escala de operação. No caso dos agricultores dos estratos menores, foi pressuposto que esses se localizavam em regiōes com maiores restriçōes ambientais (ver Tabela 4). Logo, a resposta aos investimentos "tradicionais" em tecnologias tende a ser menor. Isso é devido a pouca possibilidade de um manejo adequado das condições agroambientais existentes nas unidades de produção. Em outras palavras, as limitações de área nas pequenas propriedades, impõem o cultivo sucessivo em uma mesma área, o que concorre para a degradação do potencial natural do solo, uma vez que o uso de algumas das técnicas conservacionistas existentes é limitado por questões econômicas. Note-se, que a qualidade dos recursos naturais implica na necessidade de doses maiores de trabalho e de capital.

(13) Já no caso dos estratos maiores, a redução do rendimento deve estar correlacionada com a perda de eficiência, quando a escala de operação é expandida, pressupondo-se áreas miores cultivadas com mandioca. Isto é, uma maior escala de operação na atividade agrícola exige, de um modo geral, a introdução de vários tipos de equipamentos que facilite a redução do custo médio unitário da produção. Como o processo produtivo da mandioca ainda requer o uso de um grande contingente de 
mão-de-obra, torna-se dificil seguir nesta direção, justificando assim, os baixos rendimentos quando a área é aumentada. Ademais, deve-se considerar os aspectos ligados aos objetivos da mandiocultura nos estabelecimentos de maior área.

(14) A contribuição do efeito localização geográfica - deslocamento entre estratos de área - para as mudanças na produção de mandioca, foi praticamente desprezivel em todos os subperiodos analisados. Essa baixa magnitude do efeito localização geográfica pode ser atribuída à similaridade das técnicas de produção entre os produtores dos diferentes estratos, o que leva a rendimentos semelhantes. Apesar de alguma diferença, o coeficiente de variação da variável rendimento é relativamente baixo $(12,39 \%)$.

(15) No início do processo de "modernização" da agricultura brasileira a estratégia básica para resolver os problemas da produção agricola era baseada no desenvolvimento de tecnologias do tipo capital-intensivo. Isto equivale dizer, que o modelo era praticamente o mesmo independente do produto. Essa orientação deve ter levado à geração de tecnologias incompativeis com o ambiente agro-sócioeconômico em que vive a maioria dos produtores de mandioca. Isso se reflete na estabilidade do rendimento físico por unidade de área e no comportamento dessa variável nas pequenas propriedades e, em última análise, na politica de mudança tecnológica.

(16) Por outro lado, quando se considerou as variáveis Pmín, PMERC, PFNORD e CRDRUR defasadas em um ano (t-1), as estimativas do modelo II apresentaram um melhor ajustamento. Esta constatação provavelmente seja uma consequência da redução do ciclo da cultura da mandioca na Região Centro-Sul. Isso foi provocado pela introdução de novas variedades e pode ser caracterizado como um impacto positivo dos investimentos em tecnologias.

(17) Embora reconhecendo as limitações de se tomar o rendimento físico como um indicador do processo de mudança tecnológica, os resultadcs empíricos 
deste estudo estão sugerindo que um aumento de $10 \%$ no rendimento físico, implica em uma ampliação de $16,7 \%$ na produção de mandioca no Estado do Maranhão, onde a elasticidade-rendimento da produção foi a mais elevada. Esse resultado indica que mesmo sobre as restrições observadas neste estado, ainda existe um potencial para o crescimento da produção da cultura.

(18) Comparando-se com outros produtos, por exemplo, milho, trigo e soja, observa-se que em termos médio, relativamente, a cultura da mandioca participou com uma parcela inferior no total dos recursos aplicados em pesquisa pela EMBRAPA. Contudo, considerando-se a posição que a cultura ocupa na economia nacional, poder-se-ia admitir que o montante de recursos estaria eqüitativamente compatível. Por outro lado, outras restrições estão contribuindo para que os investimentos em pesquisa não apresentem os impactos desejados nas técnicas de produção utilizadas pelos agricultores de mandioca, havendo, portanto, a necessidade de maiores investimentos visando a identificação dessas restrições.

(19) Tem-se observado, principalmente, nas regiões onde a agricultura é mais dinâmica, uma perda relativa da participação da área plantada com mandioca em relação à área total cultivada nas respectivas regiões. Essa perda de importância da cultura, decorre das mudanças experimentadas pela agricultura brasileira (via politicas públicas) a partir do início da década de 70 . Essas mudanças estruturais foram também identificadas no comportamento do efeito-substituição nos subperiodos $1970 / 75$ e $1975 / 80$.

(20) Contrariando o esperado, observa-se que há uma tendência para que os indices de reestruturação de cultivo (IREC-) da cultura da mandioca para os diferentes estratos de área, seja de uma maior magnitude nos estratos menores subperiodos $1970 / 75$ e $1975 / 80$. Isso reflete o grau do impacto do processo de substituição de culturas, experimentado pela mandioca naquele período. 
(21) Ainda que não possa ser observado em todo o periodo analisado, pelo menos durante os anos 70 , a disputa de áreas foi mais acirrada no Brasil como um todo. Por isso, os indices de reestruturação de cultivo são mais elevados. De qualquer forma, na fase de intensificação do processo de substituição, as culturas que mais incorporaram áreas foram: pastagem plantada, soja, café e arroz. Isso se deveu à combinação de estímulos proporcionados pelo mercado e pelos incentivos diferenciados nas políticas de preço, de crédito e de geração de tecnologia.

(22) A política de incentivo diferenciado foi também quantificada por meio do índice de preço dos produtos "concorrentes" (IPPC). Esse índice contempla, além dos preços, as mudanças nas áreas colhidas e nos rendimentos dos produtos (trigo, milho e soja). A correlação negativa entre a produção de mandioca e o IPPC, indica que variações no índice, proporciona mudanças na produção de mandioca no sentido contrário. Todavia, o comportamento estatístico do coeficiente da variável IPPC, sugere que tudo mais constante, a produção de mandioca na Região Centro-Sul pode não depender do comportamento dos produtos considerados na construção do índice.

(23) Para finalizar, seria recomendável que em futuras pesquisas fossem aprofundados os seguintes pontos: (i) a suposta relação negativa entre a política de subsidio ao trigo e a produção de mandioca; (ii) a contradição econômica entre preço e produção identificada nos estados da Região Norte-Nordeste; (iii) a capacidade de resposta dos produtores de mandioca da Região Centro-Sul vis-à-vis aos da Região Norte-Nordeste aos diferentes incentivos de política agrícola; e, (iv) as perspectivas do setor em face das atuais mudanças no perfil de demanda de alimentos e da crescente integração dos mercados. 


\section{REFERÊNCIAS BIBLIOGRÁFICAS}

ADAMS, D.W. Impacto de las finanzas en el desarrollo. In: ADAMS, D.W. ; GONZÁLEZ VEGA, C. ; VON PISCHKE, J.D., ed. Crédito agrícola y desarrollo rural - la nueva vision Columbus, Ohio State University, 1987a p.11-24.

ADAMS, D.W. Son los argumentos en favor del crédito agricola barato válidos?. In: ADAMS, D.W. ; GONZÁLEZ VEGA, C. ; VON PISCHKE, J.D., ed. Crédito agrícola y desarrollo rural - la nueva vision. Columbus, Ohio State University, 1987b. p.87-101.

ALMEIDA, A. de. Mercados informais como fonte alternativa de liquidez para os agricultores. Piracicaba, 1994. 204p. (Mestrado-Escola Superior de Agricultura "Luiz de Queiroz"/USP).

ALMEIDA, I.M. da S. A oferta de feijão nos estados de São Paulo, Paraná e Minas Gerais. Piracicaba, 1994. 126p. (Mestrado - Escola Superior de Agricultura "Luiz de Queiroz"/USP).

ANUÁRIO ESTATÍSTICO DO BRASIL. Rio de Janeiro, IBGE, 1965-93.

ANUÁRIO ESTATÍSTICO DO CRÉDITO RURAL. Brasilia, BACEN, 1970-90.

ARAÚJO, P.F.C. de. Agricultura no processo de desenvolvimento econômico. In: ARAÚJO, P.F.C. de \& SCHUH, G.E., coords. Desenvolvimento da agricultura natureza do processo e modelos dualistas. São Paulo, Pioneira. 1975. p.8397. 
ARAÚJO, P.F.C. de. Análise da política de crédito à agricultura brasileira. Piracicaba, SP, 1980. 225p. (Livre-docência-Escola Superior de Agricultura "Luiz de Queiroz"/USP).

ARAÚJO, P.F.C. de. Reflexões sobre a política de crédito rural. In: ENCONTRO NACIONAL DE CRÉdITO RURAL, 1., São Paulo, 1992. Palestra. São Paulo, ASBACE - ASSOCIAÇÃO DOS BANCOS ESTADUAIS, 1992. 15p. (mimeo.).

ASSIS, C.A. Projeção de consumo de cimento usando dados de série temporal e cross-section. Pesq. Plan. Econ., Rio de Janeiro, 8(2): 437-456, ago. 1978.

BACHA, J.C. Alguns aspectos dos modelos de análise dos impactos de mudança tecnológica no comportamento do setor agrícola. R. Econ. Sociol. Rural, Brasilia, 30(1): 41-62, jan./mar. 1992.

BARNES MOLINAR, E.C. O crédito rural no Brasil: relação com a modernização e aspectos distributivos. Piracicaba, SP, 1984. 160p. (Mestrado-Escola Superior de Agricultura "Luiz de Queiroz"(USP).

BARROS, G.S.A. de C. \& ARAÚJO, P.F.C. de. Oferta e demanda de crédito rural no Brasil: algumas evidências empíricas sobre seus determinantes. Piracicaba, ESALQ/FEALQ, 1991. 32p. (Relatório de resultados, 9).

CAMARGO, A.M.M.P. Substituição regional entre as principais atividades agrícolas no Estado de São Paulo. Piracicaba, SP, 1983. 236p. (Mestrado - Escola Superior de Agricultura "Luiz de Queiroz"/USP).

CAMPOS, R.T. O impacto do ataque do bicudo na cotonicultura do semi-árido cearense. R. Econ. Sociol. Rural, Brasilia, 32(1): 75-86, jan./mar. 1994.

CARDOSO, J.L. Relações entre o crédito e as características da agropecuária nas unidades da federação. R. Econ. Sociol. Rural, Brasília, 32(1): 59-74, jan./mar. 1994. 
CARVALHO, J.L. Choques externos e a resposta: "semeando vento e colhendo tempestade na agricultura brasileira". Rev. Bras. Econ., Rio de Janeiro, 43(2): 139-175, abr./jun., 1989.

CENSO AGROPECUÁRIO. RIo de Janeiro, FIBGE, 1970-85.

CEREDA, M.P. Alternativas de uso industrial para fécula de mandioca. Rev. Bras. Mand., Cruz das Almas (BA), 8(1): 63-71, jun. 1989.

CEREDA, M.P. Importância econômica e social da mandioca no Brasil: situação na área de tecnologia pós-colheita. In: REUNIÓN REGIONAL DE COOPERACIÓN CON YUCA EN EL SUBTRÓPICO DE AMERICA LATINA, Camboriú, SC, 1990. Trabalhos. (No prelo).

COCK, J.H. \& LYNAM, J.K. La yuca en la economia de America Latina. In: PÉREZCRESPO, C.A. ed. Proyectos integrados de yuca. Cali, Colombia, CIAT, 1991. p.18-27. (CIAT- Documento de trabajo, 79).

COELHO, C.N. de A. A política de preços mínimos. Coleção Análise e Pesquisa, Brasilia, 11: 129-134, 1978.

COELHO, C.N. de A. A política de preços minmos dentro de uma perspectiva de desenvolvimento econômico. Coleção Análise e Pesquisa, Brasilia, 12: 1-138, 1979.

CONTADOR, C.R. Benefícios e custos sociais da política de garantia agricola no Brasil. In: VEIGA, A. coord. Ensaios sobre politica agricola brasileira. São Paulo, Secretária de Agricultura, 1979. p.163-205.

DURAN, T.A. A política de preços mínimos no Brasil. Coleção Análise e Pesquisa, Brasilia, 11: 141-157, 1978.

ESTUDO NACIONAL DA DESPESA FAMILIAR. Rio de janeiro, IBGE, 1: 71, 1981.

FAGUNDES, M.H. Comentários sobre crédito rural e sua evolução recente. Brasilia, DF, CFP, 1987. 180p. (Coleção de estudos especiais, 21).

FAO. Situacion y perspectivas de los productos básicos Roma, 1994. 172p. 
FEl, J.C.H. \& RANIS, G. Agrarianismo, dualismo e desenvolvimento econômico. In: ARAÚJO, P.F.C. de \& SCHUH, G.E., coords. Desenvolvimento da agricultura natureza do processo e modelos dualistas. São Paulo, Pioneira. 1975. p.101136.

FOX, R. Preços mínimos garantidos e o setor agrícola no Nordeste do Brasil. Rev. Econ. Nord., Fortaleza, 10(2): 551-604, abr./jun. 1979.

FUNDAÇÃO INSTITUTO BRASILEIRO DE GEOGRAFIA E ESTATISTICA. Estatísticas históricas do Brasil: séries econômicas, demográficas e sociais de 1950 a 1988 . 2. ed. Rio de Janeiro, IBGE, 1990. $245 p$.

GARDNER, A.L. \& OLIVEIRA, J.S. Pesquisa aplicada: geração $x$ adoção de tecnologia. Cad. Dif. Tecnol., Brasilia, 1(2): 245-263, maio/ago. 1984.

GASQUES, J.G. \& VILLA VERDE, C.M. Crescimento da agricultura brasileira e politica agrícola nos anos oitenta. Agricultura em São Paulo, São Paulo, 37(1): $183-204,1990$.

GATTI, E.U. ; VIEIRA, J.L.T.M. ; SILVA, V. da. Análise do perfil distributivo do crédito rural no Brasil, 1969-90. Agricultura em São Paulo, São Paulo, 40(1): 65-99, 1993.

GONTIJO, V;; BRANDÃO, A.S.P. ; FILHO J.P.M. Eliminação do subsidio ao trigo: uma avaliação das conseqüências econômicas. In: CONTINI, et alii, orgs. Alimentos, política agrícola e pesquisa agropecuária. Brasilia, EMBRPA, 1989. p.155-168.

GONZÁLEZ VEGA, C. Comportamiento de los acreedores agropecuarios al racionar el crédito: la ley de hierro de las restricciones a las tasas de interés. In: ADAMS, D.W. ; GONZÁLEZ VEGA, C. ; VON PISCHKE, J.D., ed. Crédito agrícola y desarrollo rural - la nueva vision. Columbus, Ohio State University, 1987a. p. 102-124. 
GONZÁLEZ VEGA, C. Crédito agropecuario artificialmente barato: redistribución al revés. In: ADAMS, D.W. ; GONZÁLEZ VEGA, C. ; VON PISCHKE, J.D., ed. Crédito agrícola y desarrollo rural - la nueva vision. Columbus, Ohio State University, 1987b. p.125-139.

HAYAMI, Y. \& RUTTAN, V.W. Desenvolvimento agrícola: teoria e experiências internacionais. Brasilia, EMBRAPA, 1988. 583p. (EMBRAPA - SEP. Documentos, 40).

HOFFMANN, R. Estatística para economista. 2.ed. São Paulo, Pioneira, 1991. $426 p$.

HOFFMANN, R. Estatística para economista. São Paulo, Pioneira, 1980. 379p.

HOFFMANN, R. \& KAGEYAMA, A. Crédito rural no Brasil: concentração regional e por cultura. R. Econ. Sociol. Rural, Brasilia, 25(1): 31-50, jan./mar. 1987.

HOFFMANN, R. \& VIEIRA, S. Análise de regressão: uma introdução à econometria. 2.ed. São Paulo, Hucitec, 1987. 379p.

HOMEM DE MELO, F. Agricultura brasileira: um novo horizonte de crescimento. Est. Econ., São Paulo, 21(3): 299-317, set./dez. 1991.

HOMEM DE MELO, F. Disponibilidade de tecnologias entre produtos da agricultura brasileira. R. Econ. Sociol. Rural, Brasilia, 18(2): 221-249, abr./jun. 1980.

HOMEM DE MELO, F. Estabilização de preços: exportáveis vs. domésticos. São Paulo, IPEA/USP, 1986. 69p. (Relatório de pesquisa, 30).

HOMEM DE MELO, F. Painel Rural. Folha de São Paulo. Agrofolha, São Paulo, 01 nov. 1994. p.4.

HOMEM DE MELO, F. Prioridade agricola: sucesso ou fracasso? São Paulo, FIPE/Pioneira, 1985. 200p.

HOMEM DE MELO, F. Um diagnóstico sobre produção e abastecimento alimentar no Brasil. Agricultura em São Paulo, São Paulo, 35 (tomo especial): 115-164, 1988. 
IBAÑEZ-MEIER, C.A. ; JANSSEN, W. ; GONTIJO, V. ; COCK, J. Economic study of cassava in Brazil. In: Centro Internacional de Agricultura Tropica. Latim american demand study: status report. Colombia, 1987. p. 3-55.

IGREJA, A.C.M. Evolução da pecuária bovina de corte no Estado de São Paulo no período de 1969-84. Piracicaba, SP, 1987. 197p. (Mestrado-Escola Superior de Agricultura "Luiz de Queiroz"/USP).

IGREJA, A.C.M. \& CAMARGO, A.M.M.P. de. A agropecuária brasileira. In: SECRETARIA DE PLANEJAMENTO E GESTÃO. Diagnósticos setoriais da economia paulista - introdução geral e agropecuária. São Paulo, 1992. p.59247. (Coleção São Paulo no limiar do século XXI).

IGREJA, A.C.M. ; CARMO, M.S. do ; GALVÃO, C.A. \& PELLEGRINI, R.M.P. Análise quantitativa do desempenho da agricultura paulista, 1966-77. São Paulo, IEA, 1982. 35p. (Relatório de pesquisa, 7/82).

IGREJA, A.C.M. ; PACKER, M. de F. \& ROCHA, M.B. A evolução da soja no Estado de Góias e seu impacto na composição agrícola. São Paulo, IEA, 1988. 20p. (Relatório de pesquisa, 16/88).

JORGENSON, D.W. Testes de teorias alternativas de desenvolvimento em economia dualista. In: ARAÚJO, P.F.C. de \& SCHUH, G.E., coords. Desenvolvimento da agricultura - natureza do processo e modelos dualistas. São Paulo, Pioneira. 1975. p. 137-152.

JUDGE, G.G.; HILL, R.C.; GRIFFITHS, W.E.; LUTKEPOHL, H.; LEE, T. Introduction to the theory and practice of econometrics. 2.ed. New York, John Wiley \& Sons, 1988. $1024 \mathrm{p}$.

KMENTA, J. Elementos de econometria 2.ed. São Paulo, Atlas, 1990. 696p. 
KRISHNA, R. Política de preços e desenvolvimento econômico. In: ARAÚJO, P.F.C. de \& SCHUH, G.E., coords. Desenvolvimento da agricultura - análise de política econômica São Paulo, Pioneira. 1977. p. 35-76.

LEE, W.F. ; BOEHLJE, M.D. ; NELSON, A.G. ; MURRAY, W.G. Agricultural Finance. 8.ed. Ames, lowa State University Press, 1988. 468p.

LEVANTAMENTO SISTEMÁTICO DA PRODUÇÃO AGRÍCOLA. Rio de Janeiro, IBGE, 1994/1995.

LIMA, U. de A. Industrialização da mandioca. In. CÂMARA, G. M. de S., GODOY, O. P. ; MARCOS FILHO, J. ; LIMA, U. de A. orgs. Mandioca - produção, préprocessamento e transformação agroindustrial. São Paulo, Secretaria de Indústria, Comércio, Ciência e Tecnologia do Estado de São Paulo/FEALQ, s.d.. p.45-80. (Série extensão agroindustrial, 4).

LOPES M. de R. A politica de preços mínimos: estudos técnicos - 1949/1979. Coleção Análise e Pesquisa Brasilia, 11: 9-18, 1978.

MARTIN, N.B. \& GONÇALVES, J.S. Estudo das mudanças na distribuição regional e na composição da área agrícola brasileira no período 1970-93. Informações Econômicas, São Paulo, 25(3): 19-48, mar. 1995.

MENDONÇA DE BARROS, J.R. Política e desenvolvimento agricola no Brasil. In: VEIGA, A., coord. Ensaios sobre política agrícola brasileira. São Paulo, Secretária de Agricultura. 1979. p.9-35.

MESQUITA, T.C. Desempenho da agricultura brasileira e sua relação com alguns instrumentos de política econômica - 1970 / 1990. São Paulo, 1994. 224p. (Doutorado - Faculdade de Economia, Administração e Contabilidade/USP).

NAKANO, Y. O crédito rural num contexto de modernização da economia brasileira.

In: SEMINÁRIO NACIONAL AS DIFICEIS OPÇÕES DO FINANCIAMENTO RURAL NO BRASIL, 1., Belo Horizonte, 1992. Anais. Belo Horizonte, CNA/FAEMG, 1992. p.1-18. 
NERLOVE, M. The dynamics of supply: estimator of farmer's respouse to price. Baltimore, The Johns Hopkins Press, 1958. 267p.

OLIVEIRA, J. do C. O papel dos preços mínimos na agricultura. Estudos Econômicos, São Paulo, 4(2): 77-95, 1974.

PAIVA, R.M. Pode a agricultura ser fator dinâmico de crescimento dos paises subdesenvolvidos? Agricultura em São Paulo, São Paulo, 37(1): 159-181, 1990.

PASTORE, A.C. A resposta da produção agrícola aos preços no Brasil. São Paulo. APEC, 1973. 170p.

PATRICK, G.F. Fontes de crescimento na agricultura brasileira: o setor de culturas. In: CONTADOR, C.R. ed. Tecnologia e desenvolvimento agrícola. Rio de Janeiro, IPEA/INPES, 1975. p.89-110.

PEREIRA, L.B. O estado e o desempenho da agricultura paranaense no período de 1975-85. R. Econ. Sociol. Rural, Brasília, 30(2): 115-133, abr.jun. 1992.

PINDYCK, R.S. \& RUBINFELD, D.L. Econometric models and economic forecastes. 3.ed. New York, McGraw-Hill, 1991. 596p.

PORTO, M.C.M. Reflexos da política agrícola na cultura da mandioca no Brasil. Rev. Bras. Mand., Cruz das Almas, 5(2): 35-53, dez. 1986.

REGO, A.J. da C. Crédito rural no Brasil: uma contribuição à análise da distribuição. Brasília, DF, 1980. 1v. (Mestrado - Universidade de Brasilia).

REGO, A.J. da C. \& WRIGHT, C.L. Uma análise da distribuição do crédito rural no Brasil. R. Econ. Sociol. Rural, Brasilia, 19(2): 217-238, abr.jun. 1981.

REZENDE, G.C. Crédito rural subsidiado e preço da terra no Brasil. Estudos Econômicos, São Paulo, 12(2): 117-137, ago. 1982. 
RYFF, T. A questão da produção e do abastecimento alimentar no Brasil: diagnóstico regional - regiões sul e sudeste. In: AGUIAR, M. de N. org. A questão da produção e do abastecimento alimentar no Brasil: um diagnóstico com cortes regionais. Brasília, IPEA/IPLAN, 1988. p. 61-135.

SANTOS, R.F. dos. O crédito rural na modernização da agricultura brasileira. R. Econ. Sociol. Rural, Brasília, 26(4): 393-404, out./dez. 1988.

SAYAD, J. Crédito rural no Brasil. São Paulo, FIPE/Pioneira, 1984. 125p.

SCHUH, G.E. Agricultura e energia no Brasil: a substituição de importação reexaminada. In: ARAÚJO, P.F.C. de \& SCHUH, G.E., coords. Desenvolvimento da agricultura - estudo de casos. São Paulo, Pioneira. 1983. p. $345-57$.

SCHUH, G.E. Efeitos de políticas gerais de desenvolvimento econômico no desenvolvimento agricola. In: ARAÚJO, P.F.C. de \& SCHUH, G.E., coords. Desenvolvimento da agricultura - análise de política econômica. São Paulo, Pioneira. 1977. p. 3-13.

SERRA, J. Ciclos e mudanças estruturais na economia brasileira do pós-guerra. In: BELLUZZO, L.G.M. \& COUTINHO, R., org. Desenvolvimento capitalista no Brasil. 2.ed. São Paulo, Brasiliense, 1983. p.56-121.

SHIROTA, R. Crédito rural no Brasil: subsídio, distribuição e fatores associados à oferta. Piracicaba, SP, 1988. 229p. (Mestrado-Escola Superior de Agricultura "Luiz de Queiroz"/USP).

SILVA, A.S. da \& KHAN, A.S. Beneficios sociais da substituição de milho por raspa de mandioca em ração suina no estado do Ceará. R. Econ. Sociol. Rural, Brasilia, 32(1): 87-98, jan./mar. 1994.

SILVA, G.L.S.P. da. Produtividade, pesquisa e extensão rural. São Paulo, IPE/USP, 1984. 143p. (Série ensaios econômicos, 40). 
SILVA, J.R. da. El cultivo de la yuca en Brasil, su desarrollo y perspectivas. In: CONGRESO LATINOAMERICANO SOBRE METODOLOGIAS APLICADAS A PROYECTOS INTEGRADOS DE YUCA, Villahermosa, Mexico, 1987. Memorias. Cali, Colombia, Centro Internacional de Agicultura Tropical. Mexico, Instituto Nacional de Investigaciones Forestales y Agropecuarias, 1989. p.9-20.

SILVA, J.R.B. da \& SILVA, M.G. da. Novos mercados para os produtos da mandioca - um enfoque empresarial - caso brasileiro. In: SEMINÁRIO AFROBRASILEIRO, 1., Maputo-Moçambique,1992. Trabalhos. Candido Mota(SP), APIMESP, 1992. 6p.

SILVA, M.G. da. Mandioca. Conjuntura Agropecuária, Brasília, 2(22): 6-9, jun. 1992.

SILVA, S.L.Q. da. O crescimento da lavoura canavieira no Brasil na década de 70 . Rev. Bras. Econ., Rio de Janeiro, 37(1): 39-54, jan./mar. 1983.

SILVA, V.M. da. A distribuição de beneficios pela regulação estatal: o caso do mercado brasileiro de trigo. Estudos Econômicos, São Paulo, 21(1): 105-136, jan.-abr. 1991.

SMITH, G.W. A politica agricola brasileira: 1950-1967. In: ARAÚJO, P.F.C. de \& SCHUH, G.E., coords. Desenvolvimento da agricultura: estudos de caso. São Paulo, Pioneira, 1983. p.213-256.

SMITH, G.W. A política de preços mínimos. Coleção Análise e Pesquisa, Brasilia, 11: $67-85,1978$.

TOLLINI, H. \& VERA FILHO, F. Progresso tecnológico e desenvolvimento. In: VEIGA, A., coord. Ensaios sobre politica agricola brasileira. São Paulo, Secretária de Agricultura, 1979. p.87-136.

VEIGA, A. Efeitos da politica comercial brasileira no setor agricola. In: ARAÚJO, P.F.C. de \& SCHUH, G.E. coord. Desenvolvimento da agricultura - análise de política econômica. São Paulo, Pioneira. 1977. p. 15-32. 
VEIGA, A. The impact of trade policy on brazilian agriculture, 1947-1967. West Lafayette, 1974. 243p. (Ph. D. - Purdue University).

VEIGA, J.E. Uma linha estratégica de desenvolvimento agricola. Revista de Economia Política, São Paulo, 12(2): 88-105, abr.jun. 1992.

VILPOUX, O. Relatório da área de sócio-economia do projeto STD3 da comunidade européia. [Botucatu, SP]. s.ed., 1994. (No prelo).

VON PISCHKE, J.D. ; ADAMS, D.W. ; DONALD, G. ed. Rural financial markets in developing countries. Baltimore, The Johns Hopkins University Press, 1983. $441 \mathrm{p}$.

VON PISCHKE, J.D. \& ADAMS, D. W. Fungibility and the design and evaluation of agricultural credit projects. American Journal Agricultural Economics, Lexinton, 62(4): 719-726, nov. 1980.

YOKOYAMA, L.P. O crescimento da produção e modernização das lavouras em Góias no periodo 1975-1984. Piracicaba, SP, 1988. 109p. (Mestrado - Escola Superior de Agricultura "Luiz de Queiroz"/USP).

YOKOYAMA, L.P. \& IGREJA, A.C.M. Comportamento da produção agrícola brasileira na Região Centro-Oeste no periodo 1975 a 1987 . Informe Econômico CNPSo/EMBRAPA, Londrina,PR, 1(3): 48-55, dez. 1993.

ZOCKUN, M.H.G.P. A expansão da soja no Brasil: alguns aspectos da produção. São Paulo, 1978. 228p. (Mestrado - Faculdade de Economia e Administração/USP). 
APÊNDICE 
Tabela A1- Área colhida, produção, rendimento médio, participação relativa na produção e indice de rendimento de mandioca nas Unidades da Federação e nas regiões fisiográficas, Brasil, 1994.

\begin{tabular}{|c|c|c|c|c|c|}
\hline $\begin{array}{c}\text { Unidades da } \\
\text { Federação/Regiőes } \\
\text { Fisiográficas } \\
\end{array}$ & $\begin{array}{l}\text { Área } \\
\text { (ha) }\end{array}$ & $\begin{array}{c}\begin{array}{c}\text { Produção } \\
\text { (t) }\end{array} \\
\end{array}$ & $\begin{array}{c}\text { Rendimento } \\
\text { Médio } \\
\text { (kg/ha) }\end{array}$ & $\begin{array}{l}\text { Participação } \\
\text { na Produção de } \\
(\%) \\
\end{array}$ & $\begin{array}{l}\text { Indice } \\
\text { de Rend. } \\
\text { (*) } \\
\end{array}$ \\
\hline Norte & 391.725 & 5.532 .158 & 14.123 & 22,62 & 107 \\
\hline Rondônia & 38.915 & 672.921 & 17.292 & 2,75 & 131 \\
\hline Acre & 23.807 & 425.818 & 17.886 & 1,74 & 135 \\
\hline Amazonas & 37.268 & 463.789 & 12.445 & 1,90 & 94 \\
\hline Roraima & 3.800 & 52.508 & 13.818 & 0,21 & 105 \\
\hline Pará & 276.070 & 3.732 .498 & 13.520 & 15,26 & 102 \\
\hline Amapá & 2.405 & 25.008 & 10.398 & 0,10 & 79 \\
\hline Tocantins & 9.460 & 159.616 & 16.873 & 0,65 & 128 \\
\hline Nordeste & 907.969 & 9.222 .185 & 10.157 & 37,71 & 77 \\
\hline Maranhão & 258.185 & 2.192 .565 & 8.492 & 8,97 & 64 \\
\hline Piauí & 68.144 & 644.000 & 9.451 & 2,63 & 71 \\
\hline Ceará & 93.384 & 734.846 & 7.869 & 3,01 & 60 \\
\hline R. G. do Norte & 49.419 & 477.348 & 9.659 & 1,95 & 73 \\
\hline Paraíba & 46.161 & 435.142 & 9.427 & 1,78 & 71 \\
\hline Pernambuco & 73.201 & 729.350 & 9.964 & 2,98 & 75 \\
\hline Alagoas & 29.831 & 395.733 & 13.266 & 1,62 & 100 \\
\hline Sergipe & 40.296 & 605.998 & 15.039 & 2,48 & 114 \\
\hline Bahia & 249.348 & 3.007 .203 & 12.060 & 12,30 & 91 \\
\hline Sudeste & 151.204 & 2.439 .899 & 16.136 & 9,98 & 122 \\
\hline Minas Gerais & 78.504 & 1.003 .918 & 12.788 & 4,11 & 97 \\
\hline Espirito Santo & 22.565 & 379.205 & 16.805 & 1,55 & 127 \\
\hline Rio de Janeiro & 14.505 & 255.026 & 17.582 & 1,04 & 133 \\
\hline São Paulo & 35.630 & 801.750 & 22.502 & 3,28 & 170 \\
\hline Sul & 325.882 & 6.078 .467 & 18.652 & 24,86 & 141 \\
\hline Paraná & 157.625 & 3.419 .935 & 21.697 & 13,99 & 164 \\
\hline Santa Catarina & 53.236 & 937.735 & 17.615 & 3,83 & 133 \\
\hline R. G. do Sul & 115.021 & 1.720 .797 & 14.961 & 7,04 & 113 \\
\hline Cento-Oeste & 72.477 & 1.179 .649 & 16.276 & 4,82 & 123 \\
\hline Mato Grosso do Sul & 30.647 & 575.859 & 18.790 & 2,36 & 142 \\
\hline Mato Grosso & 23.434 & 327.835 & 13.990 & 1,34 & 106 \\
\hline Góias & 17.960 & 269650 & 15.014 & 1,10 & 114 \\
\hline Distrito Federal & 436 & 6.305 & 14.461 & 0,03 & 109 \\
\hline Total & 1.849 .257 & 24.452 .358 & 13.223 & 100,00 & 100 \\
\hline
\end{tabular}

Fonte: Levantamento Sistemático da Produção Agricola - IBGE/CEPAGRO, jun. 95.

(*) (base média $=100$ ) 
Tabela A2 - Maiores índices de reestruturação de cultivo negativo (IREC), Brasil.

\begin{tabular}{|c|c|c|c|c|c|c|c|c|}
\hline \multirow{2}{*}{$\begin{array}{c}\text { Estratos } \\
\text { (ha) }\end{array}$} & \multicolumn{2}{|c|}{ Período: $1970 / 75$} & \multicolumn{2}{|c|}{ Período: $1975 / 80$} & \multicolumn{2}{|c|}{ Período: $1980 / 85$} & \multicolumn{2}{|c|}{ Período: $1975 / 85$} \\
\hline & Culturas & IREC (\%) & Culturas & IREC (\%) & Culturas & IREC (\%) & Culturas & IREC (\%) \\
\hline$<2$ & $\begin{array}{l}\text { Algodão arb. } \\
\text { Mandioca } \\
\text { Cana-de-açucar }\end{array}$ & $\begin{array}{r}-41,73 \\
-33,78 \\
-6,21 \\
\end{array}$ & $\begin{array}{l}\text { Milho } \\
\text { Mandioca } \\
\text { Algodão arb. }\end{array}$ & $\begin{array}{r}-66,71 \\
-27,10 \\
-6,19 \\
\end{array}$ & $\begin{array}{l}\text { Arroz } \\
\text { Past. Plantada } \\
\text { Past. Natural }\end{array}$ & $\begin{array}{r}-78,86 \\
-5,43 \\
-4,36 \\
\end{array}$ & $\begin{array}{l}\text { Arroz } \\
\text { Mandioca } \\
\text { Algodão arb. }\end{array}$ & $\begin{array}{l}-74,68 \\
-17,69 \\
-7,02 \\
\end{array}$ \\
\hline $2 a-$ de 5 & $\begin{array}{l}\text { Amendoim } \\
\text { Cafe } \\
\text { Trigo }\end{array}$ & $\begin{array}{r}-22,81 \\
-18,94 \\
-16,90 \\
\end{array}$ & $\begin{array}{l}\text { Milho } \\
\text { Arroz } \\
\text { Algodão arb. }\end{array}$ & $\begin{array}{r}-48,16 \\
-29,38 \\
-14,24 \\
\end{array}$ & $\begin{array}{l}\text { Arroz } \\
\text { Past. Natural } \\
\text { Past. Plantada }\end{array}$ & $\begin{array}{r}-34,04 \\
-13,44 \\
-10,02 \\
\end{array}$ & $\begin{array}{l}\text { Arroz } \\
\text { Algodâo arb. } \\
\text { Soja }\end{array}$ & $\begin{array}{r}-49,20 \\
-18,36 \\
-11,44 \\
\end{array}$ \\
\hline 5 a - de 10 & $\begin{array}{l}\text { Amendoim } \\
\text { Café } \\
\text { Trigo } \\
\end{array}$ & $\begin{array}{r}-24,91 \\
-23,63 \\
-20,46 \\
\end{array}$ & $\begin{array}{l}\text { Arroz } \\
\text { Milho } \\
\text { Past. Natural }\end{array}$ & $\begin{array}{r}-31,53 \\
-26,09 \\
-19,81 \\
\end{array}$ & $\begin{array}{l}\text { Café } \\
\text { Algodão arb. } \\
\text { Soja }\end{array}$ & $\begin{array}{l}-29,23 \\
-22,16 \\
-12,99 \\
\end{array}$ & $\begin{array}{l}\text { Arroz } \\
\text { Algodão arb. } \\
\text { Past. Natural }\end{array}$ & $\begin{array}{r}-36,44 \\
-21,32 \\
-19,27 \\
\end{array}$ \\
\hline 10 a - de 20 & $\begin{array}{l}\text { Mandioca } \\
\text { Trigo } \\
\text { Milho }\end{array}$ & $\begin{array}{r}-18,11 \\
-17,54 \\
-16,56 \\
\end{array}$ & $\begin{array}{l}\text { Past. Natural } \\
\text { Arroz } \\
\text { Milho }\end{array}$ & $\begin{array}{r}-44,74 \\
-28,71 \\
-16,63 \\
\end{array}$ & $\begin{array}{l}\text { Café } \\
\text { Algodão arb. } \\
\text { Soja }\end{array}$ & $\begin{array}{r}-31,48 \\
-30,81 \\
-22,38 \\
\end{array}$ & $\begin{array}{l}\text { Past. Natural } \\
\text { Arroz } \\
\text { Algodâo arb. }\end{array}$ & $\begin{array}{l}-33,91 \\
-24,88 \\
-16,60 \\
\end{array}$ \\
\hline 20 a - de 50 & $\begin{array}{l}\text { Milho } \\
\text { Past. Natural } \\
\text { Mandioca }\end{array}$ & $\begin{array}{r}-27,62 \\
-19,75 \\
-16,31 \\
\end{array}$ & $\begin{array}{l}\text { Past. Natural } \\
\text { Arroz } \\
\text { Milho }\end{array}$ & $\begin{array}{r}-70,89 \\
-13,29 \\
-11,24 \\
\end{array}$ & $\begin{array}{l}\text { Past. Natural } \\
\text { Algodão arb. } \\
\text { Soja }\end{array}$ & $\begin{array}{r}-31,29 \\
-26,88 \\
-17,96 \\
\end{array}$ & $\begin{array}{l}\text { Past. Natural } \\
\text { Algodão arb. } \\
\text { Milho }\end{array}$ & $\begin{array}{r}-66,27 \\
-11,51 \\
-10,37 \\
\end{array}$ \\
\hline 50 a - de 100 & $\begin{array}{l}\text { Past. Natural } \\
\text { Mandioca } \\
\text { Milho }\end{array}$ & $\begin{array}{r}-77,12 \\
-6,85 \\
-5,93 \\
\end{array}$ & $\begin{array}{l}\text { Past. Natural } \\
\text { Arroz } \\
\text { Milho }\end{array}$ & $\begin{array}{r}-91,52 \\
-4,30 \\
-2,67 \\
\end{array}$ & $\begin{array}{l}\text { Past. Natural } \\
\text { Algodão arb. } \\
\text { Café }\end{array}$ & $\begin{array}{r}-66,19 \\
-20,80 \\
-8,36 \\
\end{array}$ & $\begin{array}{l}\text { Past. Natural } \\
\text { Algodâo arb. } \\
\text { Arroz }\end{array}$ & $\begin{array}{r}-88,88 \\
-7,76 \\
-3,14 \\
\end{array}$ \\
\hline 100 a - de 500 & $\begin{array}{l}\text { Past. Natural } \\
\text { Mandioca } \\
\text { Feijão }\end{array}$ & $\begin{array}{r}-94,72 \\
-2,29 \\
-2,07 \\
\end{array}$ & $\begin{array}{l}\text { Past Natural } \\
\text { Arroz } \\
\text { Algodão arb. }\end{array}$ & $\begin{array}{r}-98,56 \\
-1,16 \\
-0,15 \\
\end{array}$ & $\begin{array}{l}\text { Past Natural } \\
\text { Algodâo arb. } \\
\text { Arroz }\end{array}$ & $\begin{array}{r}-72,03 \\
-10,19 \\
-6,66 \\
\end{array}$ & $\begin{array}{l}\text { Past Natural } \\
\text { Algodão arb } \\
\text { Arroz }\end{array}$ & $\begin{array}{r}-92,17 \\
-3,76 \\
-3,16 \\
\end{array}$ \\
\hline$>500$ & $\begin{array}{l}\text { Past. Natural } \\
\text { Mandioca } \\
\text { Feljâo }\end{array}$ & $\begin{array}{r}-99,41 \\
-0,29 \\
-0,26 \\
\end{array}$ & $\begin{array}{l}\text { Past Natural. } \\
\text { Algodão arb. } \\
\text { Trigo }\end{array}$ & $\begin{array}{r}-99,34 \\
-0,40 \\
-0,26 \\
\end{array}$ & $\begin{array}{l}\text { Past. Natural } \\
\text { Arroz } \\
\text { Algodäo arb. }\end{array}$ & $\begin{array}{r}-91,17 \\
-5,03 \\
-1,75 \\
\end{array}$ & $\begin{array}{l}\text { Past Natural } \\
\text { Algodão arb. } \\
\text { Trigo }\end{array}$ & $\begin{array}{r}-98,04 \\
-1,02 \\
-0,71 \\
\end{array}$ \\
\hline Total & $\begin{array}{l}\text { Past. Natural } \\
\text { Milho } \\
\text { Mandioca }\end{array}$ & $\begin{array}{r}-79,48 \\
-7,32 \\
-4,74\end{array}$ & $\begin{array}{l}\text { Past Natural } \\
\text { Milho } \\
\text { Arroz }\end{array}$ & $\begin{array}{r}-91,22 \\
-4,98 \\
-1,45 \\
\end{array}$ & $\begin{array}{l}\text { Past. Natural } \\
\text { Algodão arb. } \\
\text { Arroz }\end{array}$ & $\begin{array}{r}-84,32 \\
-6,09 \\
-4,81\end{array}$ & $\begin{array}{l}\text { Past. Natural } \\
\text { Algodão arb. } \\
\text { Arroz }\end{array}$ & $\begin{array}{r}-93,28 \\
-3,43 \\
-3,02 \\
\end{array}$ \\
\hline
\end{tabular}

Fonte: Dados básicos - Censo Agropecuário, IBGE, 1970, 1975, 1980 e 1985 
Tabela A3 - Maiores índices de reestruturação de cultivo positivo (IREC ${ }^{+}$), Brasil.

\begin{tabular}{|c|c|c|c|c|c|c|c|c|}
\hline \multirow{2}{*}{$\begin{array}{c}\text { Estratos } \\
\text { (ha) }\end{array}$} & \multicolumn{2}{|c|}{ Período: $1970 / 75$} & \multicolumn{2}{|c|}{ Período: $1975 / 80$} & \multicolumn{2}{|c|}{ Período: $1980 / 85$} & \multicolumn{2}{|c|}{ Período: $1975 / 85$} \\
\hline & Culturas & IREC (\%) & Culturas & IREC (\%) & Culturas & IREC $(\%)$ & Culturas & IREC $(\%)$ \\
\hline$<2$ & $\begin{array}{l}\text { Arroz } \\
\text { Milho } \\
\text { Past Natural }\end{array}$ & $\begin{array}{r}76,20 \\
19,13 \\
3,11 \\
\end{array}$ & $\begin{array}{l}\text { Feijão } \\
\text { Past. Plantada } \\
\text { Banana }\end{array}$ & $\begin{array}{l}23,39 \\
16,84 \\
15,85 \\
\end{array}$ & $\begin{array}{l}\text { Milho } \\
\text { Feijäo } \\
\text { Mandioca }\end{array}$ & $\begin{array}{l}68,92 \\
23,01 \\
3,90 \\
\end{array}$ & $\begin{array}{l}\text { Feijäo } \\
\text { Milho } \\
\text { Banana }\end{array}$ & $\begin{array}{l}40,90 \\
19,58 \\
7,33 \\
\end{array}$ \\
\hline $2 a-$ de 5 & $\begin{array}{l}\text { Arroz } \\
\text { Past. Natural } \\
\text { Feijâo }\end{array}$ & $\begin{array}{r}50,49 \\
19,51 \\
7,69 \\
\end{array}$ & $\begin{array}{l}\text { Past. Plantada } \\
\text { Café } \\
\text { Feijäo }\end{array}$ & $\begin{array}{l}29,84 \\
24,08 \\
20,41 \\
\end{array}$ & $\begin{array}{l}\text { Milho } \\
\text { Algodão herb. } \\
\text { Feijão }\end{array}$ & $\begin{array}{l}47,53 \\
24,91 \\
22,44\end{array}$ & $\begin{array}{l}\text { Feijâo } \\
\text { Algodão herb. } \\
\text { Past. Plantada }\end{array}$ & $\begin{array}{l}30,99 \\
24,37 \\
16,04\end{array}$ \\
\hline $5 a-d e 10$ & $\begin{array}{l}\text { Soja } \\
\text { Past. Natural } \\
\text { Arroz }\end{array}$ & $\begin{array}{l}43,81 \\
32,24 \\
19,64 \\
\end{array}$ & $\begin{array}{l}\text { Past. Plantada } \\
\text { Café } \\
\text { Fejaão }\end{array}$ & $\begin{array}{l}38,49 \\
23,02 \\
20,53 \\
\end{array}$ & $\begin{array}{l}\text { Algodäo herb. } \\
\text { Milho } \\
\text { Feijão }\end{array}$ & $\begin{array}{l}33,45 \\
23,12 \\
18,86 \\
\end{array}$ & $\begin{array}{l}\text { Past Plantada } \\
\text { Feijão } \\
\text { Algodão herb. }\end{array}$ & $\begin{array}{l}27,42 \\
26,17 \\
20,64 \\
\end{array}$ \\
\hline 10 a - de 20 & $\begin{array}{l}\text { Soja } \\
\text { Past. Natural } \\
\text { Arroz }\end{array}$ & $\begin{array}{r}68,42 \\
23,01 \\
7,08\end{array}$ & $\begin{array}{l}\text { Past Plantada } \\
\text { Feijão } \\
\text { Café }\end{array}$ & $\begin{array}{l}45,21 \\
17,15 \\
16,37\end{array}$ & $\begin{array}{l}\text { Algodão herb. } \\
\text { Feijão } \\
\text { Mandioca }\end{array}$ & $\begin{array}{l}32,45 \\
23,55 \\
14,67\end{array}$ & $\begin{array}{l}\text { Past Plantada } \\
\text { Feljão } \\
\text { Algodão herb. }\end{array}$ & $\begin{array}{l}36,23 \\
22,26 \\
15,46\end{array}$ \\
\hline 20 a - de 50 & $\begin{array}{l}\text { Soja } \\
\text { Algodão arb. } \\
\text { Café }\end{array}$ & $\begin{array}{r}82,04 \\
9,99 \\
4,33 \\
\end{array}$ & $\begin{array}{l}\text { Past Plantada } \\
\text { Soja } \\
\text { Café }\end{array}$ & $\begin{array}{l}50,82 \\
12,47 \\
10,43 \\
\end{array}$ & $\begin{array}{l}\text { Past. Plantada } \\
\text { Algodão herb. } \\
\text { Feijāo }\end{array}$ & $\begin{array}{l}30,50 \\
26,18 \\
19,39 \\
\end{array}$ & $\begin{array}{l}\text { Past. Plantada } \\
\text { Feijão } \\
\text { Algodão herb. }\end{array}$ & $\begin{array}{l}50,22 \\
14,26 \\
10,44\end{array}$ \\
\hline 50 a - de 100 & $\begin{array}{l}\text { Soja } \\
\text { Algodão arb. } \\
\text { Past. Plantada }\end{array}$ & $\begin{array}{l}54,21 \\
16,83 \\
9,87 \\
\end{array}$ & $\begin{array}{l}\text { Past Plantada } \\
\text { Soja } \\
\text { Café }\end{array}$ & $\begin{array}{l}60,02 \\
13,77 \\
9,75 \\
\end{array}$ & $\begin{array}{l}\text { Past. Plantada } \\
\text { Algodão herb. } \\
\text { Feijão }\end{array}$ & $\begin{array}{r}50,32 \\
14,60 \\
9,68\end{array}$ & $\begin{array}{l}\text { Past. Plantada } \\
\text { Soja } \\
\text { Feijão }\end{array}$ & $\begin{array}{r}60,89 \\
9,41 \\
7,04 \\
\end{array}$ \\
\hline 100 a - de 500 & $\begin{array}{l}\text { Past. Plantada } \\
\text { Soja } \\
\text { Algodão arb. }\end{array}$ & $\begin{array}{l}35,32 \\
34,93 \\
10,05 \\
\end{array}$ & $\begin{array}{l}\text { Past. Plantada } \\
\text { Soja } \\
\text { Café }\end{array}$ & $\begin{array}{r}72,82 \\
12,70 \\
4,16 \\
\end{array}$ & $\begin{array}{l}\text { Past. Plantada } \\
\text { Cana-de-açúcar } \\
\text { Soja }\end{array}$ & $\begin{array}{r}61,53 \\
9,20 \\
8,23 \\
\end{array}$ & $\begin{array}{l}\text { Past. Plantada } \\
\text { Soja } \\
\text { Cana-de-acúcar }\end{array}$ & $\begin{array}{r}71,29 \\
11,53 \\
5,56 \\
\end{array}$ \\
\hline$>500$ & $\begin{array}{l}\text { Past Plantada } \\
\text { Soja } \\
\text { Arroz }\end{array}$ & $\begin{array}{l}76,47 \\
9,58 \\
7,47\end{array}$ & $\begin{array}{l}\text { Past Plantada } \\
\text { Soja } \\
\text { Arroz }\end{array}$ & $\begin{array}{r}85,72 \\
5,92 \\
4,16 \\
\end{array}$ & $\begin{array}{l}\text { Past. Plantada } \\
\text { Soja } \\
\text { Cana-de-acúcar }\end{array}$ & $\begin{array}{r}79,48 \\
10,56 \\
5,67 \\
\end{array}$ & $\begin{array}{l}\text { Past. Plantada } \\
\text { Soja } \\
\text { Cana-de-açucar }\end{array}$ & $\begin{array}{r}85,00 \\
8,16 \\
4,04 \\
\end{array}$ \\
\hline Total & $\begin{array}{l}\text { Past. Plantada } \\
\text { Soja } \\
\text { Arroz }\end{array}$ & $\begin{array}{r}59,70 \\
26,83 \\
7,88 \\
\end{array}$ & $\begin{array}{l}\text { Past Plantada } \\
\text { Soja } \\
\text { Café }\end{array}$ & $\begin{array}{r}82,02 \\
7,85 \\
3,00 \\
\end{array}$ & $\begin{array}{l}\text { Past. Plantada } \\
\text { Soja } \\
\text { Milho }\end{array}$ & $\begin{array}{r}63,29 \\
7,65 \\
7,23 \\
\end{array}$ & $\begin{array}{l}\text { Past Plantada } \\
\text { Soja } \\
\text { Cana-de-acúcar }\end{array}$ & $\begin{array}{r}78,36 \\
8,20 \\
4,53 \\
\end{array}$ \\
\hline
\end{tabular}

Fonte: Dados básicos - Censo Agropecuário, IBGE, 1970, 1975, 1980 e 1985. 
Tabela A4 - Matriz de covariância dos erros das equações(1) componentes do modelo I [sigma $(\sigma)$ ], Pará, Maranhão e Bahia.

\begin{tabular}{llll}
\hline \multicolumn{1}{c}{ Estados } & Pará & Maranhão & Bahia \\
\hline Pará & 0,003171040 & $-0,001700963$ & 0,000914437 \\
Maranhão & $-0,001700963$ & 0,017401185 & $-0,002537643$ \\
Bahia & 0,000914437 & $-0,002537643$ & 0,004321212 \\
\hline
\end{tabular}

Fonte: Dados da pesquisa.

(1) SUR - Seemingly Unrelated Regression

Tabela A5 - Matriz de covariância dos erros das equaçōes $(1)$ componentes do modelo II [sigma $(\sigma)$ ], (Minas Gerais, São Paulo, Paraná e Rio Grande do Sul).

\begin{tabular}{llllll}
\hline \multicolumn{1}{c}{ Estados } & Minas Gerais & São Paulo & Paraná & Rio Grande do Sul \\
\hline Minas Gerais & 0,001281934 & $-0,003550083$ & $-0,000570187$ & $-0,000671732$ \\
Såo Paulo & $-0,003550083$ & 0,027332928 & 0,003251140 & 0,001006752 \\
Paraná & $-0,000570187$ & 0,003251140 & 0,011839177 & 0,000330458 \\
Rio Grande do Sul & $-0,000671732$ & 0,001006752 & 0,000330458 & 0,004993924 \\
\hline
\end{tabular}

Fonte: Dados da pesquisa.

(1) SUR - Seemingly Unrelated Regression 
Tabela A6 - Matriz de correlação linear simples, modelo I, Estado do Pará.

\begin{tabular}{|c|c|c|c|c|c|c|c|}
\hline Variáveis & $P_{\text {min }}+2$ & PMERC $_{t-2}$ & CMDOR & REND & CRDRUR $_{t-2}$ & PROD $_{\text {L-1 }}$ & $T$ \\
\hline $\mathrm{Pmin}_{\mathrm{t}-2}$ & 1,0000 & & & & & & \\
\hline PMERC $_{t-2}$ & 0,3936 & 1,0000 & & & & & \\
\hline CMDOR & 0,3305 & 0,4825 & 1,0000 & & & & \\
\hline REND & $-0,4421$ & $-0,7327$ & $-0,5758$ & 1,0000 & & & \\
\hline CRDRUR $_{\mathrm{t}-2}$ & $-0,0520$ & 0,2726 & $-0,0107$ & 0,2596 & 1,0000 & & \\
\hline PROD $_{t-1}$ & $-0,3812$ & $-0,7176$ & $-0,8090$ & 0,7306 & 0,0019 & 1,0000 & \\
\hline$T$ & $-0,3753$ & $-0,6507$ & $-0,8133$ & 0,7529 & $-0,0226$ & 0,9752 & 1,000 \\
\hline
\end{tabular}

Fonte: Dados da pesquisa. 
Tabela A7 - Resultados do ajustamento da equação referente ao Estado do Maranhão (modelo I).

\begin{tabular}{|c|c|c|c|}
\hline $\begin{array}{l}\text { Variáveis } \\
\text { Explicativas }\end{array}$ & $\begin{array}{c}\text { Coeficientes de } \\
\text { Regressão } \\
\end{array}$ & $\begin{array}{c}\text { Teste de "t" } \\
\text { Student } \\
\end{array}$ & Desvios-Padräo \\
\hline $\mathrm{Pmin}_{\mathrm{t}-2}$ & $-0,985^{\star}$ & $-3,840$ & 0,257 \\
\hline PMERC $_{t-2}$ & $0,330^{* * *}$ & 1,419 & 0,232 \\
\hline CMDOR & $-0,021$ & $-0,135$ & 0,157 \\
\hline REND & $2,194^{\star}$ & 4,665 & 0,470 \\
\hline CRDRUR $_{\mathrm{t}-2}$ & $0,040^{* * *}$ & 1,913 & 0,021 \\
\hline $\mathrm{PROD}_{\mathrm{t}-1}$ & 0,290 & 0,660 & 0,440 \\
\hline $\mathrm{T}$ & $-0,020$ & $-0,546$ & 0,037 \\
\hline \multicolumn{3}{|c|}{ - Coeficiente de determinação múltipla $\left(R^{2}\right)$} & 0,821 \\
\hline \multicolumn{3}{|c|}{ - Valor da estatística $F(7,13)$} & 8,508 \\
\hline
\end{tabular}

Fonte: Dados da pesquisa

- Niveis de significância:

$\left(^{*}\right)$ e $\left(^{* *}\right) 1 \%$ e $5 \%$ de probabilidade respectivamente.

$\left(^{* * *}\right) 10 \%$ de probabilidade (unilateral) 
Tabela A8 - Matriz de correlação linear simples, modelo I, Estado do Maranhão.

\begin{tabular}{|c|c|c|c|c|c|c|c|}
\hline Variáveis & Pmint-2 & PMERC $_{t-2}$ & CMDOR & REND & CRDRUR $_{\mathrm{t}-2}$ & $\mathrm{PROD}_{\mathrm{t}-1}$ & $\mathrm{~T}$ \\
\hline$P_{\min }{ }_{t-2}$ & 1,0000 & & & & & & \\
\hline PMERC $_{\mathrm{t}-2}$ & 0,3605 & 1,0000 & & & & & \\
\hline CMDOR & 0,2876 & 0,5221 & 1,0000 & & & & \\
\hline REND & 0,2087 & 0,3626 & 0,1430 & 1,0000 & & & \\
\hline CRDRUR $_{\mathrm{t}-2}$ & 0,0658 & 0,4174 & $-0,0320$ & $-0,0323$ & 1,0000 & & \\
\hline PROD $_{\mathrm{t}-1}$ & $-0,4047$ & $-0,7363$ & $-0,7346$ & $-0,1490$ & $-0,2551$ & 1,0000 & \\
\hline $\mathrm{T}$ & $-0,4021$ & $-0,7793$ & $-0,7793$ & $-0,1080$ & $-0,2388$ & 0,9726 & 1,000 \\
\hline
\end{tabular}


Tabela A9 - Resultados do ajustamento da equação referente ao Estado da Bahia (modelo I).

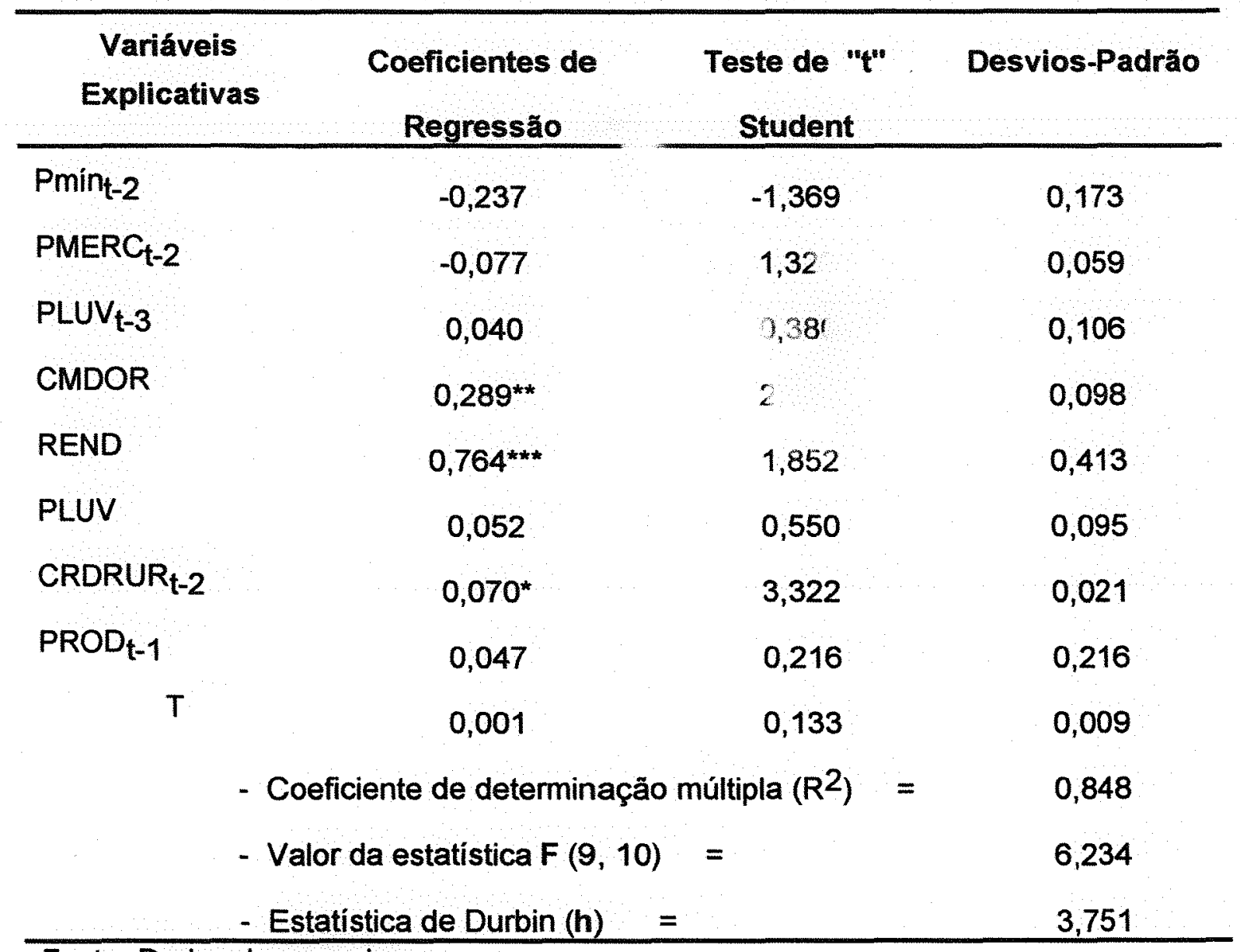

Fonte: Dados da pesquisa

- Niveis de significância:

( $^{*}$ e $\left(^{* *}\right) 1 \%$ e $5 \%$ de probabilidade respectivamente.

$(* * *) 10 \%$ de probabilidade (unilateral) 
Tabela A10 - Matriz de correlação linear simples, modelo I, Estado da Bahia.

\begin{tabular}{|c|c|c|c|c|c|c|c|c|c|}
\hline Variáveis & $P_{\text {mín }}$ & PMERC $_{t-2}$ & PLUV $_{t-3}$ & CMDOR & REND & PLUV & CRDRUR $_{t-2}$ & PROD $_{t-1}$ & $T$ \\
\hline$P_{\text {min }}$-2 & 1,0000 & & & & & & & & \\
\hline PMERC $_{\mathrm{t}-2}$ & 0,0573 & 1,0000 & & & & & & & \\
\hline PLUV $_{t-3}$ & 0,2197 & 0,0518 & 1,0000 & & & & & & \\
\hline CMDOR & 0,3111 & 0,6112 & 0,0085 & 1,0000 & & & & & \\
\hline REND & 0,3901 & 0,6631 & 0,2476 & 0,7301 & 1,0000 & & & & \\
\hline PLUV & $-0,1282$ & 0,1364 & $-0,0919$ & 0,2319 & 0,3339 & 1,0000 & & & \\
\hline CRDRUR $_{\mathrm{t}-2}$ & $-0,1176$ & 0,0378 & $-0,1147$ & $-0,1882$ & $-0,3144$ & $-0,0525$ & 1,0000 & & \\
\hline PROD $_{t-1}$ & 0,0225 & 0,3948 & 0,0756 & 0,4976 & 0,3554 & 0,0248 & 0,3505 & 1,0000 & \\
\hline$T$ & $-0,3753$ & $-0,7357$ & $-0,3143$ & $-0,7555$ & $-0,7954$ & $-0,1735$ & 0,0003 & $-0,5724$ & 1,000 \\
\hline
\end{tabular}

Fonte: Dados da pesquisa. 
Tabela A11 - Resultados do ajustamento da equação referente aos Estados de Minas Gerais, São Paulo, Paraná e Rio Grande do Sul, estimada pelo processo chamado de pooling - sem as variáveis binárias (modelo II).

\begin{tabular}{|c|c|c|c|}
\hline $\begin{array}{l}\text { Variáveis } \\
\text { Explicativas }\end{array}$ & $\begin{array}{c}\text { Coeficientes de } \\
\text { Regressão } \\
\end{array}$ & $\begin{array}{c}\text { Teste de " } \mathrm{t} \text { " } \\
\text { Student } \\
\end{array}$ & Desvios-Padrão \\
\hline $\operatorname{Pmin}_{t-1}$ & $-0,057$ & $-0,647$ & 0,089 \\
\hline PMERC $_{t-1}$ & $0,051^{* * *}$ & 1,431 & 0,035 \\
\hline IPPC & $-0,021$ & $-0,219$ & 0,094 \\
\hline CMDOR & 0,074 & 1,008 & 0,074 \\
\hline REND & $0,167^{\star \star *}$ & 1,829 & 0,091 \\
\hline PFNORD $_{t-1}$ & 0,025 & 0,548 & 0,045 \\
\hline CRDRUR $_{\mathrm{t}-1}$ & 0,006 & 0,485 & 0,012 \\
\hline $\mathrm{PROD}_{\mathrm{t}-1}$ & $1,028^{*}$ & 25,599 & 0,040 \\
\hline $\mathrm{T}$ & $0,013^{\star * *}$ & 1,792 & 0,007 \\
\hline \multicolumn{3}{|c|}{ - Coeficiente de determinação múltipla $\left(R^{2}\right)$} & 0,929 \\
\hline \multicolumn{3}{|c|}{ - Valor da estatística $F(9,78)$} & 112,931 \\
\hline \multicolumn{3}{|c|}{ - Somatório do quadrado dos resíduos $=$} & 1,570 \\
\hline
\end{tabular}

Fonte: Dados da pesquisa

- Níveis de significância:

$\left(^{*}\right)$ e $\left(^{\star *}\right) 1 \%$ e $5 \%$ de probabilidade respectivamente.

$\left.{ }^{\star \star *}\right) 10 \%$ de probabilidade (unilateral). 
Tabela A12 - Resultados do ajustamento da equação estimada pelo processo chamado de pooling (modelo II), considerando-se o modelo de covariância (Estados de Minas Gerais, São Paulo, Paraná e Rio Grande do Sul).

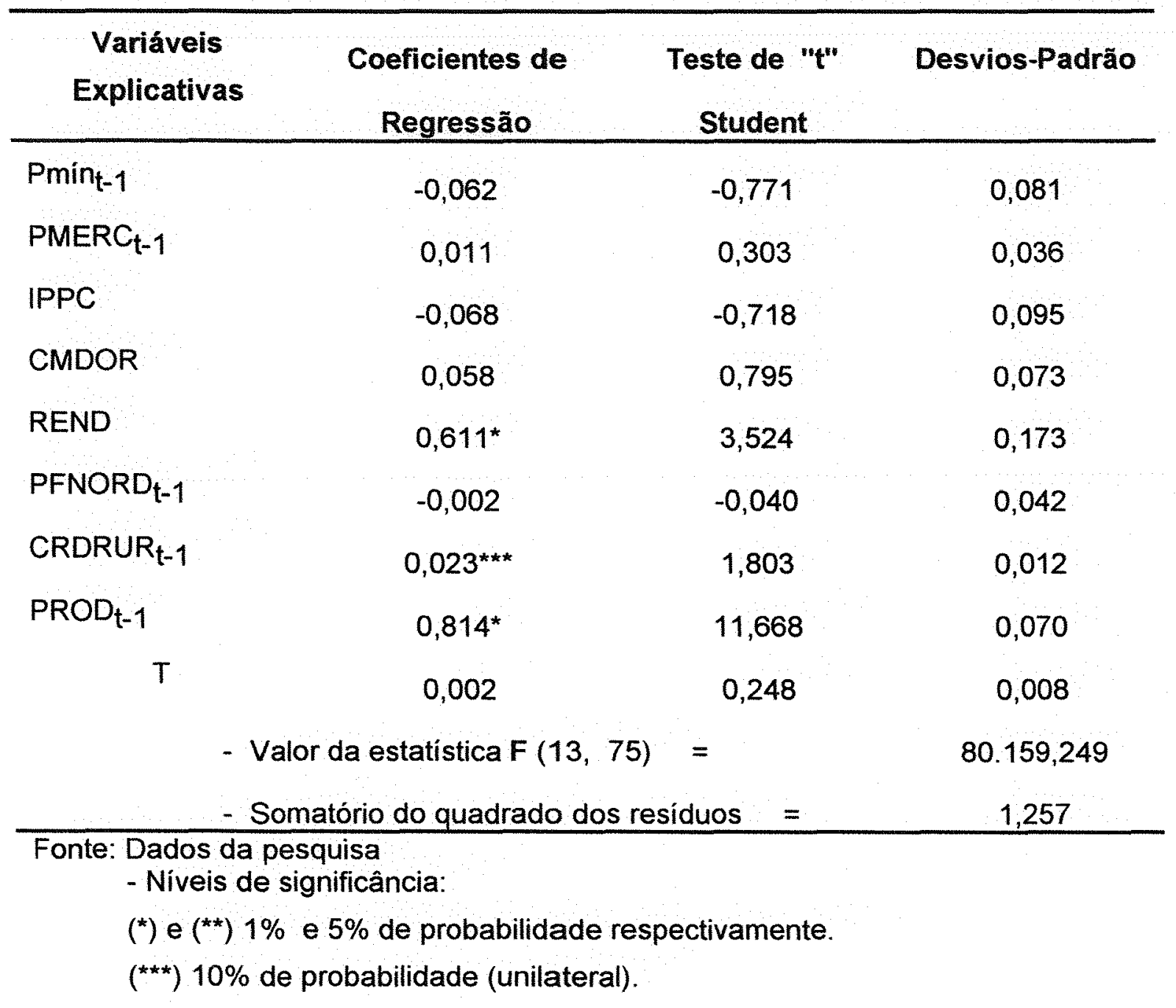


Tabela A13 - Matriz de correlação linear simples, modelo II, pooling (Minas Gerais, São Paulo, Paraná e Rio Grande do Sul).

\begin{tabular}{|c|c|c|c|c|c|c|c|c|c|}
\hline Variáveis & $P_{\min }{ }_{t-1}$ & PMERC $_{t-1}$ & IPPC & CMDOR & REND & PFNORD $_{t-1}$ & CRDRUR $_{t-2}$ & $\mathrm{PROD}_{t-1}$ & $\mathrm{~T}$ \\
\hline$P_{m i n}{ }_{t-1}$ & 1,0000 & & & & & & & & \\
\hline PMERC $_{t-1}$ & 0,2441 & 1,0000 & & & & & & & \\
\hline IPPC & 0,4525 & 0,4448 & 1,0000 & & & & & & \\
\hline CMDOR & 0,4235 & 0,3306 & 0,6520 & 1,0000 & & & & & \\
\hline REND & $-0,0681$ & $-0,4284$ & $-0,1342$ & 0,0254 & 1,0000 & & & & \\
\hline PFNORD $_{t-1}$ & $-0,0830$ & 0,2996 & 0,2743 & $-0,0216$ & $-0,0329$ & 1,0000 & & & \\
\hline CRDRUR $_{\mathrm{t}-1}$ & 0,2655 & 0,0412 & 0,4003 & 0,0858 & 0,2263 & 0,1401 & 1,0000 & & \\
\hline $\mathrm{PROD}_{\mathrm{t}-1}$ & 0,1513 & 0,0599 & 0,1942 & 0,2850 & $-0,4448$ & $-0,0703$ & $-0,0030$ & 1,0000 & \\
\hline$T$ & $-0,4812$ & $-0,5112$ & $-0,8755$ & $-0,8092$ & 0,0910 & $-0,2097$ & $-0,2995$ & $-0,2969$ & 1,000 \\
\hline
\end{tabular}

Fonte: Dados da pesquisa. 
Tabela A14 - Resultados do ajustamento da equação estimada pelo processo chamado de pooling (modelo II), considerando-se o modelo de covariância, com as devidas correções dos problemas de autocorrelação dos resíduos e heterocedasticia (Estados de Minas Gerais, São Paulo, Paraná e Rio Grande do Sul).

\begin{tabular}{|c|c|c|c|}
\hline $\begin{array}{c}\text { Variáveis } \\
\text { Explicativas(1) }\end{array}$ & $\begin{array}{c}\text { Coeficientes de } \\
\text { Regressão } \\
\end{array}$ & $\begin{array}{c}\text { Teste de " } t \text { " } \\
\text { Student } \\
\end{array}$ & Desvios-Padrão \\
\hline$P \min ^{\star \star} t-1$ & 0,017 & 0,165 & 0,100 \\
\hline $\mathrm{PMERC}^{\star \star}{ }_{\mathrm{t}-1}$ & 0,022 & 0,590 & 0,037 \\
\hline $\mathrm{IPPC}^{\star \star}$ & $-0,039$ & $-0,403$ & 0,098 \\
\hline CMDOR $^{\star *}$ & 0,103 & 1,271 & 0,081 \\
\hline REND*** & $0,734^{*}$ & 3,935 & 0,187 \\
\hline $\mathrm{PFNORD}^{\star \star}{ }_{\mathrm{t}-1}$ & 0,019 & 0,413 & 0,047 \\
\hline CRDRUR $^{* \star}{ }_{t}-1$ & $0,024^{\star \star \star}$ & 1,895 & 0,013 \\
\hline$P R O D^{\star *} t-1$ & $0,777^{\star}$ & 10,550 & 0,074 \\
\hline \multirow[t]{2}{*}{$T^{\star \star \star}$} & 0,008 & 0,878 & 0,009 \\
\hline & da estatística F (13 & $=$ & $72.663,764$ \\
\hline
\end{tabular}

Fonte: Dados da pesquisa.

(1) Os dois asteriscos (**) nas variáveis indicam que as estimativas foram efetuadas com as devidas correções para autocorrelação nos resíduos e heterocedasticia.

- Niveis de significância:

$\left.{ }^{*}\right)$ e $\left(^{* *}\right) 1 \%$ e $5 \%$ de probabilidade respectivamente.

$\left.{ }^{\star \star \star}\right) 10 \%$ de probabilidade (unilateral). 
Tabela A15 - Dados utilizados no ajustamento do modelo I.

\begin{tabular}{|c|c|c|c|c|c|c|c|c|}
\hline \multirow[t]{2}{*}{ Anos } & \multicolumn{3}{|c|}{ Produção (t) } & \multirow{2}{*}{$\begin{array}{l}\text { Preço(1) } \\
\text { mínimo (R } \$ / t)\end{array}$} & \multicolumn{3}{|c|}{ Preço de mercado $(R \$ / t)(1)$} & \multirow{2}{*}{$\begin{array}{c}\text { Pluviosidade } \\
\text { média (BA) }(\mathrm{mm})\end{array}$} \\
\hline & Pará & Maranhão & Bahia & & Pará & Maranhão & Bahia & \\
\hline 1972 & 968386 & 2083582 & 4219580 & 40,89 & & 71,06 & 104,27 & 912,3 \\
\hline 1973 & 1013675 & 1565245 & 3805297 & 47,64 & 123,06 & 82,00 & 94,45 & 912,3 \\
\hline 1974 & 912249 & 1095840 & 4768000 & 42,10 & 191,03 & 80,16 & 90,21 & 912,3 \\
\hline 1975 & 834921 & 1843008 & 5109656 & 37,67 & 189,40 & 104,71 & 136,39 & 912,3 \\
\hline 1976 & 1004322 & 2113017 & 4470000 & 34,98 & 111,56 & 123,77 & 255,45 & 511,0 \\
\hline 1977 & 1083618 & 2615928 & 4350000 & 37,92 & 74,00 & 103,09 & 221,31 & 813,0 \\
\hline 1978 & 1202748 & 2754154 & 4425000 & 39,29 & 70,59 & 87,77 & 221,26 & 959,7 \\
\hline 1979 & 1445724 & 3064612 & 4704000 & 35,84 & 102,35 & 70,60 & 130,22 & 721,1 \\
\hline 1980 & 1239329 & 3279641 & 4880000 & 29,23 & 85,82 & 80,30 & 110,63 & 920,3 \\
\hline 1981 & 1524046 & 3112240 & 5600000 & 31,48 & 70,14 & 103,40 & 104,47 & 772,5 \\
\hline 1982 & 1681529 & 3493621 & 4439200 & 42,55 & 66,06 & 73,33 & 70,76 & 630,4 \\
\hline 1983 & 1674765 & 2439249 & 4216542 & 36,67 & 36,98 & 52,72 & 45,81 & 781,9 \\
\hline 1984 & 1645339 & 1647045 & 4557073 & 29,37 & 47,91 & 58,60 & 70,82 & 488,3 \\
\hline 1985 & 1903943 & 1020691 & 5317000 & 39,41 & 52,56 & 60,12 & 61,45 & 1182,6 \\
\hline 1986 & 2315073 & 1808045 & 5421000 & 55,40 & 97,68 & 71,32 & 30,35 & 559,1 \\
\hline 1987 & 2025850 & 1966274 & 3920348 & 33,67 & 100,42 & 46,11 & 32,36 & 792,4 \\
\hline 1988 & 1908884 & 1597471 & 3438944 & 32,74 & 76,23 & 54,73 & 77,45 & 502,8 \\
\hline 1989 & 2608856 & 1820793 & 4352590 & 38,18 & 64,26 & 60,60 & 70,37 & 936,3 \\
\hline 1990 & 2894635 & 1782230 & 4152298 & 28,95 & 47,24 & 32,25 & 23,37 & 659,3 \\
\hline 1991 & 2968491 & 1962619 & 4240771 & 30,71 & 66,05 & 39,51 & 37,56 & 708,7 \\
\hline 1992 & 2626606 & 1645983 & 3770795 & 32,57 & 50,67 & 48,18 & 58,62 & 1058,4 \\
\hline 1993 & 3329088 & 1958233 & 2971260 & 25,60 & 37,60 & 42,03 & 69,58 & 430,3 \\
\hline 1994 & 3732498 & 2192565 & 3007203 & 24,55 & 34,14 & 31,89 & 40,16 & 699,2 \\
\hline
\end{tabular}

Fonte: Produção - Anuário Estatístico do Brasil e Levantamento Sistemático da Produção Agrícola, Preço Mínimo - CONAB, Preço de Mercado - FGV, Pluviosidade - 40 DISME (os dados de 1972 a 1975 refere-se a média de 30 anos).

(1) Valores deflacionados pelo IGP-DI/ FGV (ago94=100)

Continua... 
Continuação

Tabela A15 - Dados utilizados no ajustamento do modelo I.

\begin{tabular}{|c|c|c|c|c|c|c|c|c|c|}
\hline \multirow[t]{2}{*}{ Anos } & \multicolumn{3}{|c|}{ Valor da mão-de-obra rural (R\$/dia) $(1)$} & \multicolumn{3}{|c|}{ Rendimento físico médio $(\mathrm{kg} / \mathrm{ha})$} & \multicolumn{3}{|c|}{ Crédito rural para custeio $(\mathrm{R} \$)^{(1)}$} \\
\hline & Pará & Maranhão & Bahia & Pará & Maranhão & Bahia & Pará & Maranhão & Bahia \\
\hline 1972 & 10,73 & 5,58 & 5,58 & 10848 & 8774 & 17390 & 429287 & 790344 & 4862887 \\
\hline 1973 & 11,15 & 6,38 & 6,38 & 10163 & 8051 & 14018 & 437304 & 433592 & 3015972 \\
\hline 1974 & 11,04 & 8,59 & 8,59 & 9864 & 6583 & 16000 & 383558 & 722416 & 1894240 \\
\hline 1975 & 12,10 & 9,39 & 9,39 & 10100 & 8492 & 17000 & 1202485 & 2156581 & 2782625 \\
\hline 1976 & 11,36 & 8,89 & 8,89 & 10733 & 8676 & 15000 & 1689386 & 5142143 & 10426664 \\
\hline 1977 & 5,21 & 11,29 & 6,39 & 10730 & 8750 & 15000 & 2917549 & 7986040 & 14584947 \\
\hline 1978 & 6,88 & 5,08 & 6,82 & 10715 & 8595 & 15000 & 5174831 & 4948394 & 12696858 \\
\hline 1979 & 6,23 & 5,56 & 7,05 & 13000 & 8882 & 16000 & 57361233 & 18060886 & 59521638 \\
\hline 1980 & 6,77 & 6,00 & 6,58 & 12159 & 8904 & 16000 & 27497615 & 54050062 & 118604008 \\
\hline 1981 & 6,15 & 5,62 & 6,16 & 12350 & 7991 & 16000 & 31116382 & 65168401 & 146401636 \\
\hline 1982 & 5,86 & 4,75 & 4,95 & 12776 & 7761 & 12400 & 19205798 & 19569296 & 79520462 \\
\hline 1983 & 5,19 & 4,28 & 4,26 & 11046 & 6809 & 11861 & 16624486 & 3243526 & 51694373 \\
\hline 1984 & 5,12 & 4,44 & 4,28 & 12306 & 8070 & 11914 & 5573279 & 3084127 & 60123082 \\
\hline 1985 & 5,24 & 4,31 & 4,85 & 13024 & 6174 & 13000 & 4975271 & 13477502 & 92784274 \\
\hline 1986 & 8,06 & 5,37 & 6,27 & 13407 & 7918 & 13000 & 9075167 & 11740004 & 29450677 \\
\hline 1987 & 4,66 & 3,59 & 3,80 & 12610 & 8110 & 12545 & 2650605 & 5845176 & 25169015 \\
\hline 1988 & 3,84 & 2,83 & 3,23 & 12116 & 7944 & 12737 & 1223850 & 4389 & 9161636 \\
\hline 1989 & 5,24 & 3,50 & 4,14 & 13084 & 7999 & 12529 & 3256463 & 280758 & 3613501 \\
\hline 1990 & 3,34 & 2,86 & 2,94 & 12438 & 7853 & 12753 & 526106 & 212669 & 2785737 \\
\hline 1991 & 5,80 & 7,29 & 9,03 & 12760 & 8264 & 12552 & 2101820 & 1195691 & 5928697 \\
\hline 1992 & 3,16 & 4,60 & 3,37 & 12747 & 7069 & 12643 & 729575 & 812348 & 3471334 \\
\hline 1993 & 3,30 & 2,26 & 2,36 & 13369 & 8208 & 11601 & 104317 & 123789 & 1401209 \\
\hline 1994 & 2,25 & 2,87 & 2,80 & 13520 & 8492 & 12060 & & & \\
\hline
\end{tabular}

Fonte: Valor da mão-de-obra rural - de 1972 a 1976 EMBRAPA, média regional, demais anos - FGV, Rendimento Físico Médio Anuário Estatístico do Brasil e Levantamento Sistemático da Produção Agrícola, Crédito Rural - Anuário Estatístico do Crédito Rural.

(1) Valores deflacionados pelo IGP-DI/FGV (ago94=100). 
Tabela A16 - Dados utilizados no ajustamento do modelo II.

\begin{tabular}{|c|c|c|c|c|c|c|c|c|c|}
\hline \multirow[t]{2}{*}{ Anos } & \multicolumn{4}{|c|}{ Rendimento físico médio ( $\mathrm{kg} / \mathrm{ha}$ ) } & \multirow{2}{*}{$\begin{array}{l}\text { Preço da } \\
\text { ha Nord. }(R \$)(1)\end{array}$} & \multicolumn{4}{|c|}{ Crédito rural para custeio $(\mathrm{R} \$)^{(1)}$} \\
\hline & Minas Gerais & São Paulo & Paraná & Rio G. do Sul & & Minas Gerais & São Paulo & Paraná & Rio G. do Sul \\
\hline 1972 & 16371 & 19278 & 24132 & 12751 & 23,15 & 5753445 & 8217583 & 2077495 & 1813099 \\
\hline 1973 & 14911 & 17354 & 20570 & 11811 & 22,03 & 5647215 & 6069674 & 1765296 & 2038688 \\
\hline 1974 & 14825 & 18282 & 21269 & 11948 & 24,15 & 5148719 & 2416226 & 1487611 & 2626751 \\
\hline 1975 & 16312 & 18701 & 19627 & 11883 & 32,59 & 6082694 & 3855842 & 1939007 & 2770600 \\
\hline 1976 & 15791 & 20678 & 18174 & 12088 & 41,73 & 17160258 & 11895962 & 5751046 & 4908748 \\
\hline 1977 & 15497 & 21713 & 17668 & 11488 & 36,51 & 20790755 & 10558251 & 5636590 & 2988072 \\
\hline 1978 & 15078 & 21127 & 17481 & 11907 & 30,23 & 15615659 & 3646114 & 1404875 & 2738620 \\
\hline 1979 & 14973 & 19892 & 18888 & 10810 & 36,58 & 19273361 & 5901535 & 6186088 & 4688273 \\
\hline 1980 & 15091 & 18496 & 19732 & 11171 & 47,89 & 23597555 & 11663962 & 9584 & 5490743 \\
\hline 1981 & 14821 & 21140 & 18763 & 12338 & 44,65 & 24589092 & 13168368 & 6721955 & 4625814 \\
\hline 1982 & 13366 & 20963 & 19503 & 12227 & 30,02 & 23568743 & 12888378 & 12918312 & 4407314 \\
\hline 1983 & 13139 & 21700 & 19794 & 12207 & 23,43 & 11989966 & 7473762 & 5882594 & 2130030 \\
\hline 1984 & 11641 & 21155 & 19627 & 11080 & 42,89 & 8443473 & 8595885 & 10391643 & 1402169 \\
\hline 1985 & 12285 & 20362 & 20080 & 11879 & 26,67 & 13031347 & 12032236 & 14721324 & 1056779 \\
\hline 1986 & 12319 & 20147 & 19814 & 11861 & 20,36 & 12832960 & 9593435 & 14492803 & 2720326 \\
\hline 1987 & 10377 & 19562 & 21698 & 12786 & 29,14 & 4551059 & 4458697 & 6161795 & 1504507 \\
\hline 1988 & 11618 & 19962 & 21765 & 13554 & 41,71 & 305261 & 357165 & 4487454 & 211757 \\
\hline 1989 & 11423 & 21441 & 20851 & 13571 & 24,26 & 708630 & 21791036 & 6726326 & 263671 \\
\hline 1990 & 11482 & 23686 & 21448 & 14309 & 8,23 & 938904 & 2367948 & 6394050 & 203210 \\
\hline 1991 & 12800 & 23377 & 22117 & 13423 & 44,62 & 1274318 & 3503819 & 9521083 & 151181 \\
\hline 1992 & 12228 & 23373 & 22527 & 14623 & 27,96 & 494023 & 3733309 & 15135429 & 46219 \\
\hline 1993 & 13004 & 23648 & 21853 & 15058 & 19,49 & 246344 & 1734331 & 10228906 & 6589 \\
\hline 1994 & 12788 & 22502 & 21697 & 14961 & 18,76 & & & & \\
\hline
\end{tabular}

Fonte: Rendimento Físico Médio - Anuário Estatístico do Brasil e Levantamento Sistemático da Produção Agrícola, Preço da Farinha no Nordeste CONAB, Crédito Rural - Anuário Estatístico do Crédito Rural.

(1) Valores deflacionados pelo IGP-DI/ FGV (ago94=100). 
Tabela A17 - Dados(1) básicos utilizados no cálculo da redundância da distribuição do crédito rural entre culturas.

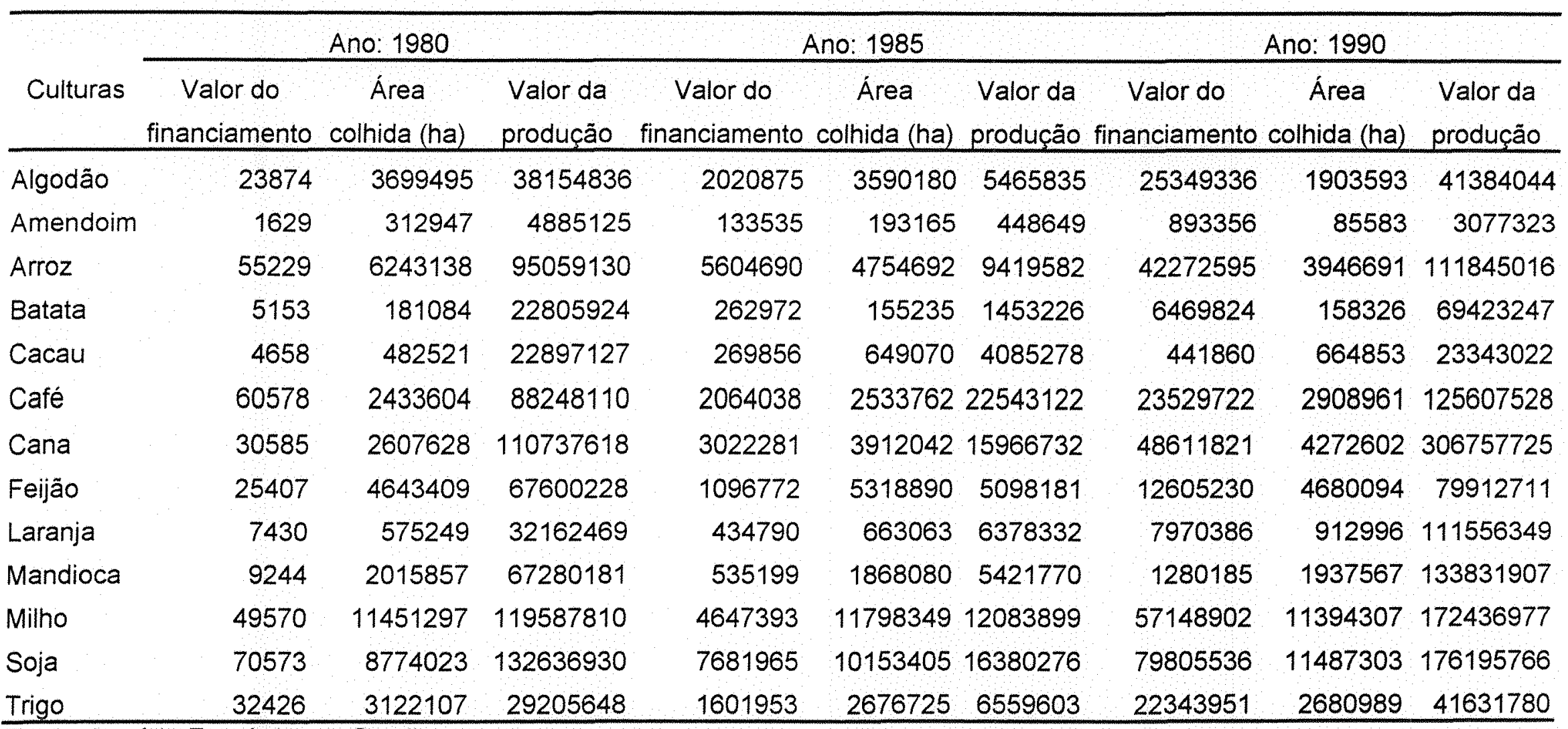

Fonte: Anuário Estatístico do Brasil.

(1) Os valores monetários estão expressos em moeda corrente. 
Tabela A18 - Dados básicos usados no cálculo da redundância da distribuição do crédito rural entre Estados.

\begin{tabular}{|c|c|c|c|c|c|c|c|c|c|c|c|c|c|c|c|}
\hline \multirow[b]{2}{*}{ Estado } & \multicolumn{3}{|c|}{ Ano: 1970} & \multicolumn{3}{|c|}{ Ano: 1975} & \multicolumn{3}{|c|}{ Ano 1980} & \multicolumn{3}{|c|}{ Ano: 1985} & \multicolumn{3}{|c|}{ Ano: 1990} \\
\hline & $\begin{array}{l}\text { Val. financ. } \\
\text { (Cr } \$ 1.000)\end{array}$ & Area (ha) & Produção (t) & $\begin{array}{l}\text { Val financ. } \\
(C-\$ 1.000)\end{array}$ & Area (ha) & Produçāo $(\mathrm{t})$ & $\begin{array}{l}\text { Val financ. } \\
\text { (Cr } \$ 1.000)\end{array}$ & Area (ha) & Produçâo $(t)$ & $\begin{array}{l}\text { Val. financ. } \\
\text { (CZ\$) }\end{array}$ & Area (ha) & Produção (t) & $\begin{array}{l}\text { Val. financ. } \\
(C r \$ 1.000)\end{array}$ & Área (ha) & Produção (t) \\
\hline Rondônia & 24 & 735 & 12670 & 51 & 5750 & 122740 & 10930 & 17886 & 279361 & 0 & 29261 & 493378 & 113992 & 30005 & 491690 \\
\hline Acre & 126 & 4669 & 97984 & 0 & 10550 & 140580 & 16762 & 14548 & 211964 & 0 & 16265 & 283867 & 5015372 & 17962 & 335905 \\
\hline Amazonas & 177 & 14834 & 423823 & 4521 & 43365 & 617120 & 764210 & 68950 & 827403 & 0 & 79514 & 954172 & 6376966 & 40538 & 465413 \\
\hline Roraima & 2 & 594 & 11880 & 99 & 780 & 8024 & 53169 & 1224 & 17508 & 0 & 1557 & 21558 & 0 & 2132 & 29459 \\
\hline Pará & 92 & 76473 & 832092 & 3200 & 82666 & 834921 & 630151 & 101929 & 1239329 & 1415036 & 146185 & 1903943 & 32710767 & 232732 & 2894635 \\
\hline Amapá & 76 & 1314 & 15186 & 901 & 1930 & 19300 & 35796 & 3405 & 34050 & 0 & 4259 & 46099 & 480575 & 2268 & 23835 \\
\hline Maranhăo & 352 & 227263 & 2075162 & 5739 & 217021 & 1843008 & 1238642 & 368322 & 3279641 & 19027183 & 165320 & 1020691 & 13222771 & 226953 & 1782230 \\
\hline Piaul & 634 & 67217 & 542047 & 2591 & 70059 & 545153 & 451131 & 104026 & 833966 & 35865237 & 66911 & 1013463 & 80543807 & 168216 & 2296626 \\
\hline Ceará & 1290 & 137895 & 1866606 & 5857 & 145050 & 1450500 & 273260 & 155000 & 1085000 & 7004009 & 95570 & 764979 & 7224724 & 124718 & 1009511 \\
\hline R. G. do Norte & 653 & 53806 & 348481 & 2088 & 61711 & 488293 & 197373 & 54044 & 486168 & 993394 & 53964 & 540999 & 15396824 & 43350 & 352904 \\
\hline Paraiba & 1796 & 52511 & 545206 & 3270 & 72647 & 641764 & 52254 & 65595 & 554169 & 1096206 & 56264 & 521251 & 8141327 & 46002 & 386340 \\
\hline Pernambuco & 2254 & 140597 & 1644323 & 6985 & 157500 & 1575000 & 720627 & 179600 & 1508649 & 3616592 & 144555 & 1474707 & 14640990 & 119637 & 1131122 \\
\hline Alagoas & 169 & 45527 & 379522 & 1651 & 47856 & 492771 & 34974 & 31854 & 288276 & 533153 & 16094 & 148369 & 3576032 & 19968 & 212803 \\
\hline Sergipe & 1873 & 44807 & 782963 & 8980 & 34705 & 416460 & 156445 & 29580 & 408470 & 780473 & 35158 & 462292 & 9842457 & 34177 & 508856 \\
\hline Bahia & 4221 & 225795 & 4013920 & 7405 & 300568 & 5109656 & 2717997 & 305000 & 4880000 & 21417396 & 409000 & 5317000 & 173203863 & 325596 & 4152298 \\
\hline Minas Gerais & 2293 & 120631 & 2004119 & 16187 & 137665 & 2245633 & 540775 & 128524 & 1939585 & 800525 & 91254 & 1121063 & 58376556 & 82708 & 949652 \\
\hline Espirito Santo & 724 & 52641 & 877710 & 14550 & 43406 & 607684 & 178078 & 27223 & 408495 & 1020167 & 29267 & 492046 & 57243697 & 19505 & 318721 \\
\hline Rio de Janeiro & 813 & 43638 & 550922 & 1895 & 25500 & 344250 & 324943 & 12492 & 175165 & 0 & 12379 & 191509 & 3540538 & 12261 & 195216 \\
\hline Săo Paulo & 3759 & 97103 & 1827383 & 10261 & 38500 & 720000 & 219628 & 26004 & 480957 & 728858 & 38537 & 784679 & 146014791 & 22880 & 541947 \\
\hline Paraná & 539 & 88243 & 2118782 & 5160 & 99530 & 1953470 & 333508 & 45982 & 907310 & 346379 & 85800 & 1722864 & 398764577 & 101854 & 2184599 \\
\hline S. Catarina & 6783 & 142816 & 3017231 & 17410 & 85846 & 1429241 & 125829 & 60995 & 995195 & 161200 & 88443 & 1182230 & 65286054 & 67596 & 1162239 \\
\hline R. G. do Sul & 2081 & 287812 & 3607767 & 7373 & 266429 & 3165972 & 56143 & 153939 & 1719631 & 133459 & 127601 & 1515830 & 12634619 & 121466 & 1738106 \\
\hline Mato Grosso & 110 & 31145 & 711466 & 870 & 57085 & 856275 & 61701 & 38452 & 601420 & 0 & 50652 & 803043 & 129434577 & 51573 & 814596 \\
\hline Golás & 151 & 66391 & 1155230 & 539 & 34800 & 487200 & 46549 & 21020 & 301044 & 3211 & 23880 & 339680 & 38357857 & 22770 & 335030 \\
\hline D. Federal & 1 & 100 & 1800 & 261 & 497 & 2599 & 3439 & 263 & 2893 & 0 & 390 & 5070 & 41233 & 700 & 8400 \\
\hline
\end{tabular}

Fonte: Anuários Estatísticos do Brasil e do Crédito Rural. 